FACULDADE DE FILOSOFIA, LETRAS E CIÊNCIAS HUMANAS

\title{
DEPARTAMENTO DE TEORIA LITERÁRIA E LITERATURA COMPARADA
}

\author{
Felipe Bier
}

Formação e realismo: forma e história em Sagarana

Tese apresentada ao Departamento de Teoria Literária e Literatura Comparada da Faculdade de Filosofia, Letras e Ciências Humanas da Universidade de São Paulo, para obtenção do título de Doutor em Letras.

Orientadora: Prof ${ }^{\mathrm{a}}$. Dr ${ }^{\mathrm{a}}$. Ana Paula Pacheco

São Paulo

2016 
Autorizo a reprodução e divulgação total ou parcial deste trabalho, por qualquer meio convencional ou eletrônico, para fins de estudo e pesquisa, desde que citada a fonte.

Catalogação na Publicação

Serviço de Biblioteca e Documentação

Faculdade de Filosofia, Letras e Ciências Humanas da Universidade de São Paulo

Bier, Felipe
Formação e realismo: forma e história em Sagarana /
Felipe Bier ; orientadora Ana Paula Pacheco. - São
Paulo, 2016.
261 f.
Tese (Doutorado)- Faculdade de Filosofia, Letras
e Ciências Humanas da Universidade de São Paulo.
Departamento de Teoria Literária e Literatura
Comparada. Área de concentração: Teoria Literária e
Literatura Comparada.
1. Literatura Brasileira. 2. Guimarães Rosa. 3.
Coronelismo. 4. Teoria Literária . 5. Marxismo. I.
Pacheco, Ana Paula , orient. II. Título.




\section{Agradecimentos}

Agradeço ao corpo docente do Departamento de Teoria Literária e Literatura Comparada por providenciar um ambiente de pesquisa e ensino favorável à formação de pensamento crítico sobre a literatura: esta dedicação, presente em todos os professores com quem tive a felicidade de conviver durante os últimos quatro anos, tornou possível o amadurecimento de pontos essenciais desta pesquisa. Suas críticas, comentários e elogios, nos vários ambientes de discussão ainda presentes na universidade, ajudaram-me a reunir as forças necessárias para terminar este trabalho.

Devo muito também aos funcionários da Universidade de São Paulo, em especial àqueles com quem trabalhei mais de perto, no Departamento de Teoria Literária e Literatura Comparada. É justo dizer que, sem seu esforço, nenhum trabalho acadêmico seria possível.

Ele também seria inviável sem o auxílio financeiro da CAPES, sou grato à instituição por isso.

A Ana Paula Pacheco, agradeço pela orientação zelosa e exigente, e sobretudo pelo diálogo intelectual franco e comprometido que foi estabelecido nesta quase meia década de trocas de ideias e impressões. Sua dedicação serve como testemunho da importância do papel de orientação em qualquer trabalho crítico.

Devo uma nota de agradecimento especial ao professor Timothy Bewes, da Brown University, que me acolheu na universidade norteamericana e que, em nossas conversas e discussões teóricas, abriu-me frentes de trabalho que hoje são partes inalienáveis desta tese. Destaco também os esforços de Luiz Fernando Valente em me inserir no rico 
ambiente do Departamento de Estudos Portugueses e Brasileiros da mesma universidade.

Aos amigos e família, desnecessário gastar muita tinta falando de sua importância. A amizade e carinho, nestes casos, não só desafiaram a solidão do ofício acadêmico como me mostraram que o pensamento não se faz para si mesmo, mas para os outros. Obrigado por aturar todas as dificuldades e privações que a escolha pela lida intelectual implica.

A Carolina Serra Azul, um agradecimento especial pela inspiração e inúmeras trocas sobre o mesmo objeto. Espero continuá-las ainda por muito tempo.

A Jessie e Poppy, por fim, sou eternamente grato pela alegria do dia-a-dia, pois isto é o mais importante. 


\section{Resumo}

Esta tese tem como objeto a formação histórica da obra de João Guimarães Rosa. Com foco nas narrativas de seu livro de estreia, Sagarana, de 1946, o texto trabalha com a seguinte hipótese: no livro, para além da experimentação de técnicas literárias que marcam a obra de Rosa como um todo, há nele a preocupação com um objeto histórico que é o sertão. A tese passa pela caracterização deste objeto, formado, a nosso ver, a partir das tensões políticas da Primeira República. O acompanhamento do objeto em Rosa também pressupõe uma inserção do autor na tradição da literatura brasileira pós-1930, em que a autonomia do objeto-sertão passa ao proscênio da representação. Chega-se assim à segunda hipótese do texto: esta autonomia e a importância do sertão para a literatura de 1930 a 1964 ligam-se às próprias dinâmicas que impulsionaram o país à industrialização. As novas necessidades emergidas do capitalismo industrial em gestação põem em primeiro plano o destino das populações pobres no sertão, das quais dependem sem reservas. A terceira hipótese trabalhada na tese é, portanto, a de que o tratamento sério do objeto-sertão em Rosa oferece um desafio às teorias formativas: tanto a forma rosiana como as teorias sociais que se preocuparam com a formação do país teriam se alimentado do mesmo empuxo integrativo sob a indústria; mas o objeto-sertão funcionaria como outro à utopia que atribuiu a essas dinâmicas a capacidade de construir uma cidadania efetiva no país. A tese demonstra como a atenção de Rosa a este objeto muito específico - as revoluções da matéria social do sertão - tem como consequência, em sua apreensão formal, o atravessamento da utopia formativa, revelando o ponto de impossibilidade de uma construção burguesa. 


\begin{abstract}
This dissertation focuses on the historical formation of the work of João Guimarães Rosa. With the emphasis on his debut book, Sagarana, from 1946, this text works with the following hypothesis: beyond technical and literary experimentation, present throughout Rosa's body of work, there is in Sagarana a commitment to a historical object, the sertão. This dissertation accompanies the characterization of the object, born from the social tensions of the Brazilian First Republic. By following this object in Rosa's work, we assume his insertion in the post-1930's tradition, in which the autonomy of the object-sertão comes to the forefront of literary representation. We thus arrive at our second hypothesis: this autonomy and its importance to literature from 1930 to 1964 find an explanation in the very dynamics that propelled the country towards industrialization. The new needs that arose with the emerging process of industrialization highlight the fate of poor populations of the sertão, on which they depend without reservations. The third hypothesis presenting itself in this work is therefore that the serious commitment to the object-sertão offers a challenge to the formation theories brought about the same period: the rosian form, as much as the social theories concerned with the formation of the country, would have benefited themselves from the same momentum granted by the integrative efforts of the industry. But the object-sertão would pose as an other to these theories' utopian projections, which impregnated these dynamics with the hope that the industrial processes would bring about an effective sense of citizenship to the country. This dissertation demonstrates how Rosa's attention to this very specific object - the revolutions on the sertão's social matter -, when formalized, bursts through the formative utopia, thus revealing the point of impossibility of a bourgeois construction in Brazil.
\end{abstract}


Índice

Introdução

1. O sertão como objeto

1.1 A emergência do sertão

35

$1.2 \mathrm{O}$ sertão como excrescência ideológica

43

1.3 O sertão como objeto fantasmático

48

2. A volta do marido pródigo

$\begin{array}{ll}\text { 3. Sarapalha } & 97\end{array}$

4. Conversa de bois 135

5. A hora e a vez de Augusto Matraga 176

$\begin{array}{ll}\text { 6. Formação e realismo } & 227\end{array}$

Bibliografia 


\section{Introdução}

Em se tratando de Guimarães Rosa, um dos muitos lugares comum a respeito do pensamento sobre sua obra é de que ele nasceu de uma encruzilhada. A imagem, tão utilizada pelo autor, tornou-se conceito crítico por empréstimo - como que um presente do escritor para aqueles que quisessem pensar sua obra. É justo dizer, por este motivo mesmo, que este trabalho nasceu da encruzilhada de uma encruzilhada, ou de uma encruzilhada em segunda potência. Isto porque, depois de mais de meio século de pesquisas sobre o autor, desassociar a voz da crítica e a voz do próprio Guimarães Rosa - ou se preferirmos, a voz da forma -, tornou-se uma tarefa com desafios próprios. A encruzilhada que deu origem a algumas das questões deste trabalho nasceu de uma desconfiança: a saber, algo ocorreu com a crítica brasileira que alçou Rosa ao patamar de maior nome da literatura nacional do último século. Este incidente gerou uma crítica apaixonada e até militante, que produziu trabalhos importantes no campo da linguagem; pesquisa genética; esforços eruditos que colocavam à luz da tradição as ligações de Rosa com o cânone etc. 
Floresceu também uma safra considerável de críticas filosóficas e, dentro destas, as de cunho metafísico que, em larga medida, responsabilizaram-se por armar a encruzilhada a que nos referimos. A resposta à presumida grandeza de Rosa passa pela extração simples de conceitos das obras rosianas, algo como uma filosofia inerente à obra. Esta operação básica, a tradução de ideias de um campo a outro, da filosofia à literatura, arma um resultado inesperado, que é o oposto de uma crítica conceitual. Trata-se no fundo de uma impossibilidade crítica que fala a mesma língua de nossa primeira encruzilhada: a de um trabalho antifilosófico e anticrítico perante uma forma particularmente intrigante. A estrutura deste motivo interpretativo é simples: o labor crítico resume-se nestes casos à analogia de ideias vinculadas pelo texto a conceitos da filosofia. O crítico em si não produz conceitos através da obra de Rosa pois sua tarefa interpretativa é, como dissemos, a tradução de conteúdos ficcionais em linguagem filosófica. Neste caso, a crítica coloca-se de lado nesta relação entre conceitos e ficção, apenas assegurando o trânsito entre uma instância e outra. Ao se falar de um trabalho anticonceitual presume-se que os dois níveis interpretativos - filosófico e literário - são autossuficientes e apenas comunicam seus conteúdos. Ou seja, não há nada que o crítico possa fazer senão intermediar uma relação que a princípio se basta em si e necessita apenas do trabalho de decifração.

A primeira encruzilhada - esta leitura anticonceitual - se coloca como questão a esta outra encruzilhada crítica: por que a literatura de Rosa exerce tal efeito sobre sua interpretação? A necessidade, essencial para este trabalho, de encarar essa encruzilhada forma-se como ângulo privilegiado deste trabalho: quebrar este efeito de apaixonamento significaria asseverar um princípio que mediasse as instâncias atuantes na forma rosiana de modo a colocá-las todas em relação e, ao mesmo tempo, erigir conceitos críticos que nascessem deste encontro com a forma. Seguimos aqui a 
pista de Antonio Pasta Júnior, que, ao final da década de 1990 e depois, sugeriu que uma relação anti-conceitual da crítica frente a Rosa ligava-se em nível mais profundo à maneira como a forma rosiana se apresenta: a saber, haveria uma associação entre forma e crítica que, em sua própria negação de um elemento mediador, revelaria um traço mais profundo da forma brasileira e, em específico, o nexo desta com a história de nossa modernização ${ }^{1}$. Em outras palavras, o fato de a forma de Rosa parecer saltar sobre a história teria atraído um tipo de crítica que mimetizava o mesmo movimento; o esforço contra-corrente, portanto, deveria passar, primeiro, pela análise do que é a história em Guimarães Rosa e, segundo, por que esta se apresenta como não-mediada.

Muito foi feito neste sentido: o maior feito de autores como Wille Bolle e outros talvez tenha sido estabelecer o debate histórico como tão necessário quanto o debate da linguagem rosiana, sobretudo se pensarmos que ainda hoje é aceitável a opinião de que autores como Guimarães Rosa nada tem com a história, esta sendo apenas um 'porém' sobre o qual o autor soube pular e erigir sua obra monumental e universal. Após duas décadas de discussão e muita tinta gasta a respeito, é possível afirmar entretanto que aquela primeira encruzilhada continua a fazer vacilar o conceito de história em Rosa. Isto porque a mesma crítica que afirmou a inevitabilidade da matéria brasileira no autor, fazendo-a conversar com a tradição literária do país, com correntes políticas e eventos históricos, hesita ao firmar a historicidade específica de sua forma: isto é, a pergunta 'qual é a formação histórica da obra de Guimarães Rosa' encontra respostas em algumas hipóteses; mas importante é notar que a análise detalhada destes escritos revela, ainda, resquícios da mesma estrutura da antiga crítica rosiana; ou seja, via de regra, o conceito de história

\footnotetext{
${ }^{1}$ Ver PASTA JÚNIOR. Formação supressiva: constantes estruturais do romance brasileiro. 2011 e "O romance de Rosa: temas do Grande Sertão e do Brasil”, 1999.
} 
coloca-se ao lado de alguns outros e recebe o mesmo tratamento dos demais, não necessariamente servindo à mediação entre forma e sociedade.

Tomemos de exemplo o comentário de Roncari sobre a relação de Grande sertão: veredas e o getulismo. Grosso modo, o crítico afirma a vacilação da forma e, mais especificamente, de Riobaldo como herói, relaciona-se à falta de pai. Trata-se de uma assunção que encontra algum lastro na obra: mas, desta constatação, o crítico salta à afirmação de uma nostalgia do pai autoritário que toma a nação pela mão e lhe indica os caminhos ${ }^{2}$. A dupla historicidade de Grande sertão, com um pé na primeira república e nos anos 1950, é explicada então pela nostalgia da autoridade: na primeira república, faria eco aos teóricos conservadores que ressentiam a debacle do império; nos anos 1950, à ruína (ainda que questionável) do getulismo.

O exemplo serve apenas para mostrar como não há, de fato, debate histórico neste caso. Há ainda a correspondência de traços ficcionais com eventos históricos. Mas não há nenhuma construção crítica que permita uma entrada na obra rosiana através da presumida hipótese da ausência paterna senão a mera analogia entre conteúdos. Noutras palavras: a história não emerge como palco de disputas no qual o conservadorismo, por exemplo, pudesse exprimir-se como forma. Ele está lá quase como dado a ser apreendido pelo crítico erudito, que sabe decifrar os rastros de sua presença a despeito da forma. Isto é, o argumento mimetiza o funcionamento da chave metafísico-filosófica: a forma existe e tem as características que se mostram à crítica. Mas sua existência é concebida em camadas, algumas delas criticáveis (como a possível simpatia autoritária de Rosa). Mas presume-se uma camada mais profunda da obra - a forma - impenetrável aos comentários críticos pois é entidade autônoma e, portanto, historicamente inabalável.

\footnotetext{
${ }^{2}$ Ver RONCARI, O Brasil de Rosa, 2004, p.63.
} 
O questionamento ao porquê deste impasse foi o motor principal desta pesquisa. Mais especificamente, uma desconfiança de que a forma de Rosa, e sobretudo o poder que exercia sobre a crítica, estavam atados historicamente. Ou seja, junto com Pasta Júnior, podemos dizer que o que a forma recalca e lhe dá a aparência de impenetrabilidade é a chave histórica que procuramos. Uma pista para esta chave histórica residiria precisamente na cisão operada pela crítica que, como sintoma, indicaria o que se procura suprimir: a saber, a relação de Rosa com a tradição e a matéria histórica da primeira metade do século passado.

A personagem principal desta trama crítico-histórica foi Antonio Candido: desde suas notas iniciais sobre Sagarana até o consagrado ensaio "O homem dos avessos", o crítico insistiu na importância do autor para a tradição brasileira e insistiu em conceitos - como o de reversibilidade - que dessem conta da fenomenologia da obra de Rosa e de sua relação com a história de seu século. Para um entendimento da questão, é necessário desviarmo-nos à própria noção de tradição para Candido, que em sua composição contém um nexo fundamental entre história, forma e crítica. Para Candido nunca restou dúvida quanto ao pertencimento de Rosa ao que o próprio crítico cunhou como 'tradição da literatura formada'; isto é, não haveria uma instância da forma pertencente a esta tradição que fosse inacessível à crítica. Todos os elementos que ligavam Rosa ao regionalismo, mais explícitos, e ao modernismo e realismo dos anos 1930, arrisco dizer, eram evidentes ao crítico e diziam respeito a movimentos mais amplos da tradição. Cumpria a esta relação crítica/literatura uma postura diferente do puro desvendamento: tratava-se, antes de tudo, de uma função quase civilizatória, na qual deslindar os laços de pertencimento e superação da tradição apontavam - sob a forma de conceitos críticos - possíveis caminhos para o pensamento sobre o país e seu lugar na história. 
Note-se o caso de "O homem dos avessos": o texto é sabidamente a fonte de muitas das vertentes críticas futuras, mas é largamente conhecido pela tese que catapultou a crítica universalista de Rosa: o Sertão é o Mundo. O caminho para a conclusão, no entanto, não é nada linear: Candido equilibra a análise do Grande sertão entre diversas frentes, a principal delas sendo a comparação com Os sertões. Para além disso, há uma noção do que é o sertão como objeto literário; um objeto que se revela pouco a pouco, à medida que o crítico acompanha as entradas e saídas do objeto no mito e na história. A oscilação, por fim, acaba sendo o efeito principal do ensaio, garantindo a força da descoberta de Candido, verdadeiramente conceitual: a noção de reversibilidade.

Fala-se do acesso ao estatuto de conceito por um motivo que talvez tenha sido obscurecido pelas muitas possibilidades de leituras que o ensaio permitiu; a razão de sua existência é todavia simples: o constante deslizamento entre mito e história não é um movimento em falso para Candido - não se trata, por exemplo, da saída da verdade histórica e entrada em seu falseamento. As entradas e saídas forjam um pano de fundo que ganha consistência em cada um destes movimentos críticos: a saber, à medida que o ensaio avança, não há dúvida sobre o objeto que sustenta e une em coerência o pertencimento duplo ao mito e à história, que é a própria ideia de Sertão (explicitamente capitalizado, por motivos que explicaremos adiante).

Vejamos as linhas finais do argumento, que melhor explicita a questão:

$\mathrm{O}$ jagunço, sendo o homem adequado à terra, ('O Sertão é o jagunço') não poderia deixar de ser como é; mas ao manipular o mal, como condição para atingir o bem possivel no Sertão, transcende o estado de bandido. Bandido e não-bandido, portanto, é um ser ambivalente, que necessita revestir-se de certos poderes para definir a si mesmo (CANDIDO, 2006c, p.129, grifos meus). 
Note-se a noção de reversibilidade atuando aqui como conceito que cose o objeto que, para Candido, deve ser o Sertão. O deslizamento se dá sobre o objeto e forja portanto o motivo literário de Grande sertão, que é esta função formal construída por Rosa que possibilita este vai e volta entre a história e mito. Noutras palavras, a forma de Rosa está indubitavelmente vinculada à história, que é aqui representada pela ideia de sertão, mas constitui-se como um pulso que oscila do chão social à invenção literária.

Este pulso, não obstante, ainda é sustentado pelo verdadeiro objeto da obra, ainda o Sertão. Para Candido, o fato de o objeto comportar a entrada no mito não o desabona e, ainda mais importante, não obriga o crítico a uma dupla mirada sobre a obra - uma histórica, outra meramente literária. Este é o ponto que afasta a crítica de Candido da grande maioria das leituras posteriores. É o ponto que nos interessa aqui neste tentativa de reerigir uma leitura conceitual de Rosa. Afirma o crítico, em nota final:

Se o leitor aceitou as premissas deste ensaio, verá no livro um movimento que afinal reconduz o mito ao fato, faz da lenda símbolo da vida e mostra que, na literatura, a fantasia nos devolve sempre enriquecidos à realidade do quotidiano, onde se tecem os fios da nossa treva e da nossa luz, no destino que nos cabe [...]. Entremos nessa realidade fluida para compreender o Sertão, que nos devolverá mais claros a nós mesmos e aos outros. O Sertão é o Mundo. (Idem, p.130, grifos meus). 
O argumento causa desconforto ao leitor contemporâneo pois não é evidente o que Candido pretende expressar com esta recondução do mito ao fato. Sabe-se que o crítico não se refere a um objeto mimético - o sertão - pois a forma comportaria em si mesma um extravasamento desta própria mimese, muito embora mantenha relações íntimas com ela. Candido com efeito aposta num efeito do objeto sobre o leitor, e este seria efetivamente o fato a que se atribui um trânsito final da obra. Neste ponto tornase clara a distinção entre sertão como objeto histórico e o Sertão como conceito propriamente candidiano: isto porque o sertão de Rosa não sugere um estancamento em sua oscilação, mas o conceito de Candido sugere que esta oscilação - tornada objeto crítico - guarda uma oscilação de outro nível. A saber, entre a matéria brasileira, a fantasia, e um ponto de fuga: a recondução ao fato que, neste caso, diz respeito ao efeito da forma sobre o leitor.

Este efeito explica a fusão entre Sertão e Mundo, pois trata-se da interação entre a realidade brasileira e uma consequência utópico-civilizatória. Nesta fusão mesma está a chave de leitura de Candido, que marca o seu pertencimento à tradição de pensadores da Formação do Brasil: uma tradição que, dos anos 1930 a 1960, sustentou a possibilidade de conhecimento da matéria brasileira alinhada às expectativas da integração do país a uma ordem civilizatória. Trataremos mais deste assunto no capítulo a seguir: o que importa agora é notar que o fusionamento do objeto Sertão só se sustenta se mantida esta projeção utópica, que afirma a possibilidade de extravasamento da mimese do sertão em direção à formação de um efeito estético real, como expressão da matéria brasileira num dialeto nãoparticularista. Em poucas palavras, seria possível dizer que a grande estima que Candido reserva a Guimarães Rosa reside neste poder da tradução da mimese em uma forma que possa afetar a ideia de civilização: por isso o tom vago destas 
considerações finais, da afecção do sertão rosiano sobre o cotidiano e sobre noções fundamentais à própria noção ampla de mitologia da civilização humana: luz e trevas, destino etc. Neste sentido é perceptível a profundidade do vínculo temático do ensaio sobre Rosa, originalmente publicado em 1957, com o espírito da Formação da literatura brasileira, que veio a público dois anos depois.

Decerto é impossível hoje seguir o argumento de Candido e escorar este ideal civilizatório, como sustentou em artigo Ana Paula Pacheco tratando dos problemas da equação 'o Sertão é o Mundo'ㄱ. Daí, talvez, o elemento que a própria forma rosiana elide e o traço que promove a aliança histórica feita entre crítica e a obra de Rosa à luz nossa não-formação. Desta aliança, o nascimento da encruzilhada crítica a que nos referimos. A saber, no momento em que se atesta a não-formação do país, vista de qualquer ângulo que se queira (inclusive o de Candido), a identificação Sertão = Mundo passa a soar como um 'tampão' explicativo; neste ponto, a vibração do conceito de Candido perde força. As saídas para solucionar a claudicância da armadura candidiana nas correntes críticas que se alimentaram de seus achados passam todas, acredito, pela repressão do fusionamento entre forma e civilização proposto por Candido. Isto é, de um lado tem-se a crítica que estanca a vibração da forma rosiana ao reprimir seu vínculo com a história, mantendo somente a parte do argumento que diz respeito à forma (como entidade autônoma) e sua relação com seus efeitos humanistas, agora pensados não mais como formas civilizatórias, mas simplesmente como pertencimento à cultura ocidental (sob as vestes da filosofia, da tradição literária, religião etc.).

Do outro lado há a crítica histórica, que, não necessariamente negando os vínculos de Rosa ao cânone (em muitos casos somente substitui a metafísica pela

\footnotetext{
${ }^{3}$ Ver PACHECO, "Jagunços e homens livres pobres: o lugar do mito no Grande sertão", 2008.
} 
filosofia política, a psicanálise etc.), ainda firma o pé sobre a relação entre as particularidades do contexto brasileiro e a forma. Esta relação todavia apega-se a um estranho legado do ensaio de Candido: a saber, se o extravasamento da mimese no mito é um dado formal, e se este mito mostrou-se uma inverdade histórica, a forma rosiana deve necessariamente ser considerada cindida. Isto é: há uma parte dela que diz respeito à história - aos arranjos políticos, jagunços, coronelismo -, mas a instância do mito atravessa todas estas camadas da forma de modo a evidenciar onde a história falta e onde a invenção literária predomina como um salto sobre o vazio histórico. Assim, como afirmamos acima, passa-se a considerar que há duas alternativas na análise histórica de Rosa: por um lado, pode-se supor que o núcleo duro da invenção literária é inacessível historicamente e diz respeito ao gênio de Guimarães Rosa. Em outra opção, comportada dentro desta matriz crítica, pode-se presumir que esta negatividade do mito é também um dado da mimese: neste caso, uma mimese da interrupção, ou da não-formação do país que reclama por sua vez a invenção literária como salto sobre a história.

Em vista dos problemas com o conceito de história nestas interpretações, os apontamentos de Pacheco, que atingem os problemas da imediaticidade da equação Sertão $=$ Mundo, parecem versar sobre a necessidade de uma interpretação que atinja também a identidade que funda esta equação. Esta crítica, ao mesmo tempo em que rejeita os espólios humanistas do texto de Candido, testa os limites de sua relação com a história: ou seja, a pergunta que é feita à forma torna-se 'se não é possível sustentála sobre uma força humanista genérica na mesma medida em que não se pode admitir o mito dentro de uma utopia civilizatória, do que se trata afinal?'.

Ainda que de maneira não inteiramente consciente, este teste da história - ou o 'limite histórico', como prefere a crítica - aponta duplamente à forma: trata-se de 
falar do limite histórico da mimese do sertão, bem como do entendimento do mito dentro desta mesma mimese. Esta visada antiutópica contra Candido acaba por clamar por uma história da não-formação do Brasil em sua relação com a civilização. Consequentemente, ao chamar a atenção para a classe de dependentes pobres do sertão - objetos principais da mitificação - como aspecto da mimese que não comporta o trânsito à invenção, Pacheco acaba investindo sobre a necessidade de uma reinterpretação do sertão como objeto em face da ideia de civilização. A revisitação do próprio fusionamento proposto por Candido pode revelar algo que, para o crítico, parecia ser uma consequência do próprio tratamento do sertão como objeto, mas que as décadas seguintes trataram de enterrar: a saber, a consciência de que o sertão não era um objeto simples e que, em sua própria ebulição social, cosia-se uma relação com a civilização. $\mathrm{O}$ teste histórico passa a figurar, portanto, não só como um teste à mimese de Rosa, mas um teste também a esta relação.

A diferença está nesta afirmação: se por um lado muitos críticos tomaram a não-formação como dado, quase como expressão de uma inadequação natural do Brasil aos padrões civilizatórios, a asserção de uma história da não-formação oferece uma mudança de perspectiva sobre a obra de Rosa. Dentro desta nova perspectiva, é possível que o fusionamento pretendido por Candido seja em verdade o maior achado de seu texto: a assunção de uma proposta simples, que é a de que a mimese do sertão guarda uma relação conturbada com a ideia de civilização.

Esta crítica necessária ao ensaio de Candido nos lhe obriga um retorno; um recuo à própria posição de Candido como crítico é peça fundamental para o enquadramento das questões desta pesquisa e para a reafirmação de uma leitura conceitual e histórica de Guimarães Rosa. Isto porque um questionamento às premissas de Candido não impede o reconhecimento de que o ensaio funciona por 
algum motivo. Como já propusemos, seu funcionamento advém de sua força conceitual, a que neste momento devemos atribuir uma força histórica. A saber, o trânsito da mimese à utopia deve ser subsidiado por um empuxo histórico que dá dinâmica ao conceito e apoia o vaivém da reversibilidade. A coisa se dá, no ensaio de Candido, como se a mimese do sertão permitisse o deslizamento na utopia: como se a apreensão do sertão como objeto literário estivesse ligada ao mesmo movimento histórico que sustenta a própria possibilidade de uma utopia formativa.

Este é, para esta tese, o momento em que se sai da encruzilhada crítica que assistimos se armar nas décadas que seguem o ensaio de Candido: um posicionamento interpretativo que viu o fracasso histórico da utopia candidiana, mas ainda assim manteve intacto o esqueleto de seu argumento, sem questionar de onde vinha sua real força. Desejo propor como hipótese, portanto, o seguinte movimento: o reconhecimento de que a utopia formativa não pode ser usada como artifício crítico; mas que esta reclama uma interpretação a contrapelo. Isto é: a compreensão de onde vem este empuxo utópico pode, a um só tempo, mostrar aspectos da mimese rosiana, percebida por Candido, e também revelar onde a tese candidiana falha: a saber, em sua proposta civilizatória. Com efeito, desejo manter a ideia básica de Candido - de que há uma relação entre a mimese do sertão e a civilização - mas que esta se dá em negativo, de tal modo que o deslizamento da mimese no mito não permita um caminho à civilização, mas a seu contrário, ao seu dorso negativo.

Existe, no "Homem dos avessos", e mais ainda em "Jagunços mineiros de Cláudio a Guimarães Rosa”, a clara consciência do crítico de que o sertão não era um 'achado' da literatura: a saber, um objeto que sempre esteve lá, presente em nossa matéria social, à espera de representação. Candido mostra a luta e as dificuldades da literatura regionalista em apreender este objeto; e ao remeter Grande sertão: veredas 
a uma raiz euclidiana, no "Homem dos avessos", o crítico também revela uma linha de consistência nos experimentos de Rosa ligada a uma tradição específica. O reconhecimento de uma tradição aponta para problemas especificamente literários - o posicionamento do narrador ante o objeto, por exemplo, parecia crucial a Candido. Mas ao se falar em tradição, sobretudo com Candido, fala-se também do estatuto social de um objeto literário. Isto é, remete-se inevitavelmente a uma matéria social que, de Euclides da Cunha a Guimarães Rosa, tornou-se inevitável à literatura que se preocupava em dar forma a um assunto brasileiro. Vemos aqui novamente a ligação com os desejos formativos, e neste ponto podemos arriscar a hipótese - a ser trabalhada na tese - de que a força do "Homem dos avessos" advém da consciência de que o sertão era um objeto instável - tanto literariamente quanto socialmente. Mais do que isto - e aqui vê-se a raiz da utopia candidiana -, ao destino do sertão vinculava-se uma expectativa mais ampla sobre a estabilização do objeto.

Trocando em miúdos, subjaz na armadura crítica de Candido a ideia de que a formalização rosiana do objeto significa sua superação, aqui talvez entendida em termos de uma dialética histórica. A estabilidade do conceito de Candido é garantida por estes dois polos que se conectam em seu esquema interpretativo: a mimese de um objeto 'selvagem' e sua resolução formal apontam para uma possível resolução histórica do problema do sertão. Esta resolução, aparentemente, é o que catapultaria a possibilidade da utopia 'à brasileira': a saber, um processo de integração que não recalcasse o sertão, mas que o absorvesse na chave de um processo civilizatório heterônomo. A constituição de uma civilização heterônoma é o tutano da utopia de Candido, e este é o ponto que mais merece atenção nesta reinterpretação de nossa história da não-formação. 
Com efeito, propõe-se que Candido estava certo quanto à importância do objeto sertão e que, portanto, o empuxo histórico que o leva à sua conceituação é real. Também se supõe que Candido acerta ao considerar que Rosa dá um fecho a esta tradição, o que indica alguma estabilização do sertão como matéria social. Todavia, no momento em que rejeitamos a solução candidiana (ou formativa), esta leitura a contrapelo reincide sobre a própria mimese rosiana. A coisa se dá nos seguintes termos: o comprometimento com a mimese histórica do sertão envolve uma ambiguidade que não escapou a Candido; trata-se de uma ambiguidade quanto aos processos de integração do país sob a indústria que de fato liga-se às projeções formativas, mas que ao mesmo tempo as trai. Dito de modo simples, a estabilização do sertão como matéria social diz respeito à integração do país, mas não da maneira como Candido a imaginou. Neste sentido, o aspecto surpreendente da forma rosiana é a habitação dentro e fora da integração civilizatória do país: dentro, pois a ebulição do sertão concerna às décadas de rápida industrialização; fora, porque o sertão forma-se como objeto ao ser rasgado por este processo de integração. O que a mimese mostra, portanto, não é tanto a integração em si, mas seu avesso: o ponto de corte em que nenhuma utopia pode se formar e onde o mito se mostra como as marcas, sobre a forma, da matéria social em revolução.

Com isso afirmamos com Candido que os traços fundamentais da obra de Rosa advêm deste único gesto: a apreensão do sertão enquanto parte do processo de integração do país. Contra Candido, porém, afirma-se que o outro que habita a forma rosiana não reside numa projeção utópica, mas na mimese em si e nas consequências que ela lega à forma: o outro, neste caso, seria o próprio corte na noção de civilização. O aspecto diabólico desta forma, diz Candido, surge "como acicate permanente, estímulo para viver além do bem e do mal" (CANDIDO, 2006c, p.128). Esta espora 
demoníaca, no entanto, não se apresenta aqui como quis o crítico: o ponto em que o real encontra a invenção, esta última entendida como sugestão de uma integração civilizatória para além da civilização, como queria a utopia formativa. O diabo revolvendo a forma não sugere nenhuma propulsão utópica porque é ela mesma o dorso da civilização; um ponto que se liga a ela, mas vista da perspectiva de seu corte.

Esta pesquisa propõe portanto este esforço metacrítico não porque ele seja, de fato, nosso objeto. Mas porque a proposta de uma interpretação histórica e conceitual da obra de Rosa contra a noção de civilização nos leva a crer que os impasses da crítica se impõem quase como sintoma. Neste caso, a manutenção do trânsito proposto por Candido, da forma rosiana à civilização, parece ter restado no corpo da crítica do autor como objeto escondido; às vezes como pulo ao universal; às vezes como ressentimento pela não-formação. Do ângulo que se olhe, é necessário reafirmar este objeto recalcado para que, enfim, se dê um passo para além da utopia formativa.

Em face do que se discutiu até aqui, é importante dizer algumas palavras sobre as intenções desta tese. Cumpre notar que o objetivo deste trabalho nunca foi o de escrutinar uma obra específica de Guimarães Rosa, mas o de propor uma mudança de perspectiva interpretativa sobre sua narrativa como um todo: a saber, uma leitura conceitual e histórica de sua forma. A proposta, é claro, é ambiciosa demais para caber numa tese. Inicialmente, a intenção era abarcar três de suas obras - Sagarana, Grande sertão: veredas, Primeiras estórias - com o intuito de mostrar um empuxo único, porém mutante, nesta apreensão do sertão como objeto. O projeto mostrou-se impossível, mas aguarda oportunidades futuras de realização. Parte desta 
impossibilidade adveio da própria necessidade de mergulhar mais fundo numa interpretação histórica que abarcasse o sertão nesta chave exposta acima - pertencente aos processos de integração industrial do país, mas como um fantasma destes mesmos. Importante dizer que muitos dos esforços desta pesquisa concentram-se na face literária deste problema: a saber, como adequar os achados sobre a matéria social a uma teoria do romance/realismo que não operasse verdadeiros desrespeitos à configuração da obra de Rosa. Havia, de minha parte, uma insistência em sustentar este ponto: a ficção de Rosa deve encontrar expressão teórica nesta tradição do pensamento sobre o romance burguês. A relutância - muito acertada, diga-se - de minha orientadora em aceitar esta proposição forçou-me à crítica das próprias teorias do realismo, que aparece no capítulo final desta tese. Este movimento aproximou-me também da crítica de Candido, sobretudo da Formação da literatura brasileira, onde percebi inquietações vizinhas às deste texto. Com efeito, alinho-me a Candido quando se trata da necessidade de revisão destas teorias frente à literatura brasileira; mais do que isto, acredito haver no texto de Candido a suposição de que conceitos devem ser criados e lapidados neste confronto com obras que desafiam a produção teórica europeia sobre o realismo. Penso não se tratar de uma aposta no 'exotismo' de nossa literatura, mas da necessidade de se aprofundarem as pesquisas sobre a relação entre capitalismo e forma literária.

Por último, gostaria de tratar da escolha de Sagarana como objeto principal de estudo. Pesou na escolha o surpreendente fato de o livro ter recebido atenção crítica esparsa se comparado ao Grande sertão. Ainda mais escassas foram as tentativas de interpretação da obra como um todo: as novelas, em muitos casos, foram analisadas em função de um eixo temático, ou simplesmente serviram de apoio para leituras de outros textos do autor. Em outras ocasiões, formularam-se interpretações autocontidas 
de novelas como "A hora e a vez de Augusto Matraga", talvez o texto mais estudado do livro. O desenrolar das análises das novelas do livro mostrará a tentativa de unificar as leituras das novelas em torno de um interesse: o de demonstrar a gênese daquilo que consideramos as linhas fortes da forma rosiana; isto é, as leituras estão submetidas à ideia de que estas linhas apreendem um objeto social específico, que é o sertão.

Como em muitos escritos de Rosa, não é muito fácil determinar o período histórico em que as estórias se passam; felizmente - e graças a esforços de críticos como Luiz Roncari e Nildo Benedetti - é possível identificar referências que as localizam, em sua maioria, no período da primeira república. Este dado é importante, por motivos que ficarão claros no capítulo seguinte: podemos adiantar, no entanto, que é nas décadas que compreendem este ciclo político-econômico que o sertão começa a emergir com força como objeto ao pensamento político, sociológico e, claro, à literatura. A proximidade da escrita de Sagarana ao período em questão ${ }^{4}$ interessa por motivos óbvios. Mas é importante delinear que, desde o início, a forma de Rosa constitui-se numa dupla temporalidade (que, em Grande sertão: veredas seria explorada com grande efeito): a saber, os anos pré e pós getulismo. Considera-se que o interesse de Rosa pela primeira república não seja fortuito: o enquadramento das narrativas neste período guia grande parte das temáticas trabalhadas pelo autor, do jaguncismo ao coronelismo. Mas o arranjo final desta forma, em nossa opinião, só pode ter lugar no ciclo que sucede a primeira república: este é o momento em que o sertão se desembrenha de uma acirrada disputa civilizatório-ideológica e emerge como objeto autônomo.

\footnotetext{
${ }^{4}$ Cumpre lembrar que a primeira versão da maioria das novelas foi escrita em 1937, agrupadas sob o título de Sezão, livro que na ocasião tinha doze narrativas.
} 
Esta emersão enquanto autonomia do objeto constitui, a um só tempo, o maior achado e maior dilema crítico que esta perspectiva interpretativa oferece. Isto porque a emersão não necessariamente significa uma superação do sertão, mas sua contínua compressão social sob os novos arranjos industriais. Esta compressão é percebida, nas narrativas, como forças que colocam-se para além do conteúdo imediato das novelas, mostrando-se sobretudo no vacilante posicionamento dos narradores e na força de totalização a que as narrativas acedem através destas estratégias narrativas. A autonomia do objeto sertão mostra-se portanto como a possibilidade de vislumbrar os nexos do sertão da primeira república a processos de totalização, ligados às dinâmicas capitalistas das décadas seguintes. De modo mais simples, poder-se-ia dizer que a maior prova da dupla temporalidade da obra de Rosa reside em uma de suas características principais: a de fazer o mundo da primeira república esparramar-se para além de suas fronteiras históricas. Esperamos mostrar que este efeito de distorção - ou a famosa tópica do mito - nasce da perspectiva adotada pela forma: um compromisso profundo com o sertão como objeto, colocado por sua vez sob a esteira de integração do país via industrialização. O sertão serve portanto como objeto e agente deste processo; funciona como suporte a ele, mas por ele é, ao mesmo tempo, destruído. Daí sua ambiguidade como objeto: como lâmina e corte; autônomo e subjugado.

Neste sentido, procurar-se-á construir uma análise que é fiel aos textos escolhidos, mas que se esforça em expandir suas leituras para além de Sagarana e em direção a este entendimento mais amplo da forma de Rosa. Esta expansão, no entanto, não almeja sugerir que os textos de Sagarana somente podem ser compreendidos criticamente à luz de outros textos 'maiores', como Grande sertão. Em verdade, propõe-se exatamente o contrário: a grandeza de Grande sertão talvez só seja 
compreensível se as linhas de força que atuam na obra forem reconhecidas em seu caráter diverso, destoante e por vezes até truncado. Reconhecer na forma rosiana o espaço aberto a estas quebras, recuos; sulcos e vazios de sentido é um importante passo crítico, pois demonstra os difíceis caminhos da forma em seu comprometimento com o objeto sertão, suas ambiguidades e dilemas; e Sagarana, em toda sua diversidade de estratégias narrativas, temas e resultados, mostra-se mais uma vez um objeto privilegiado para este projeto.

Ao final do trajeto, esperamos que o leitor tenha clareza de uma unidade possível da obra sob esta perspectiva, a despeito da escolha que fizemos das novelas cujo tratamento oferece melhores entradas à temática proposta. Resultado ainda mais feliz será obtido se esta leitura inspirar a possibilidade de reinterpretação de pontos importantes de uma obra que, não obstante o volume de atenção que recebeu, ainda pode instigar uma produção conceitual importante para o pensamento da tradição brasileira de literatura. 


\section{O sertão como objeto}

Em 1979 vinha a público a comunicação escrita por Antonio Candido "O papel do Brasil na nova narrativa" na ocasião do encontro que delineava as características marcantes da ficção latino-americana. De maneira significativa, este texto chegou até nós em sua versão definitiva, no livro $A$ educação pela noite ${ }^{5}$, com a supressão da primeira parte do título. Chamado apenas de "A nova narrativa", o papel do Brasil pode ter sido elidido apenas por questão editorial - afinal, ao contrário do encontro acadêmico para o qual o texto foi produzido, a coletânea de ensaios direcionava-se majoritariamente ao público brasileiro. Mas não é difícil pensar em outras razões para o ocorrido. É possível cogitar que, na ocasião da leitura da comunicação, a dimensão comparativa entre as literaturas latino-americanas de língua espanhola, com autores e traços característicos e em grande destaque na época, exigisse o realce das particularidades do único representante de língua portuguesa no continente. Curiosamente, no entanto, Candido aponta para as semelhanças com o

\footnotetext{
${ }^{5}$ CANDIDO, Antonio. A educação pela noite. $5^{\text {a }}$ ed. Rio de Janeiro: Ed. Ouro sobre Azul, 2006.
} 
contexto hispano-falante apenas como limite de sua exposição: o aporte histórico, menos do que evidenciar a história comum, caminha pelo trilho da diferença, almejando com isto tornar claro o ponto de vista brasileiro enquanto suporte para a comparação.

O destaque da contribuição do Brasil à nova narrativa é pois menos técnico e tem a ver com um projeto mais ambicioso de representação da história literária. A história das nossas letras, descrita por Candido, obedece ao conhecido ritmo de seu empenho ${ }^{6}$ na apreensão de um objeto brasileiro. Isto é, a apreciação das obras toma a perspectiva do ponto de condensação de um sistema que lutou para a consolidação de uma tradição. A análise do sentido desta história de ganhos e conquistas no terreno formal é portanto o que interessa a Candido. Ressoando trabalhos mais importantes do crítico, "A nova narrativa" abreviadamente posiciona o objeto de análise de sorte a ressaltar o árduo processo de sedimentação formal brasileiro.

Entretanto as inserções críticas do ensaio em questão têm de enfrentar uma instabilidade. Como se disse, o resultado imediato da leitura de "A nova narrativa" é de que se fala de uma perspectiva brasileira na literatura. Mas com isso contrasta o carregado efeito de dispersão ressaltado por Candido como traço principal da nova literatura e que torna 'o papel do Brasil' um significante vacilante. Isto é, muito

\footnotetext{
${ }^{6}$ A noção de empenho é fundamental para a construção do argumento candidiano em Formação da literatura brasileira. Em resumo, o conceito se refere a um traço curioso da literatura do país, perceptível já em seus primeiros esforços. Trata-se do interesse em vincular literatura e pensamento sobre o Brasil, suas peculiaridades e seu imaginário. Candido atribui este traço ao fato de as elites dirigentes do país serem também sua elite intelectual, portanto interessada em literatura. Claro, o argumento se complexifica à medida que se inserem as noções de forma e tradição na análise, já que se por um lado o empenho gerava um interesse importante para a aglutinação da literatura em torno de um objeto comum, ao mesmo tempo não a fixava ao redor de padrões formais consistentes, dada a volatilidade do pensamento das elites. Para Candido, a junção de tradição e forma só ocorrerá em Machado de Assis, que não por acaso encerra o estudo em Formação da literatura brasileira, de 1959. Para um entendimento mais aprofundado da discussão, é imprescindível a remissão as estudos de Roberto Schwarz sobre a obra de Machado, nos quais o crítico testa a tese candidiana com um potente arsenal teórico. Tocaremos neste tópico adiante.
} 
embora o crítico demonstre conhecer a fundo a produção contemporânea à escrita da comunicação, o texto culmina num sentimento de impossibilidade de agrupar tais tendências em torno de uma linha de sentido que torne palpável uma tradição brasileira. Como afirma o crítico em seu último parágrafo,

na literatura brasileira atual há uma circunstância que faz refletir: a ficção procurou de tantos modos sair das suas normas, assimilar outros recursos, fazer pactos com outras artes e meios, que nós acabamos considerando como obras ficcionalmente mais bem realizadas e satisfatórias algumas que foram elaboradas sem preocupação de inovar, sem vinco de escola, sem compromisso com a moda; inclusive uma que não é ficcional. Seria um acaso? Ou seria um aviso? Eu não saberia nem ousaria dizer. Apenas verifico uma coisa que é pelo menos intrigante e estimula a investigação crítica. (CANDIDO, 2006a, p.260).

A perda do fio da tradição talvez seja verdadeira, mas a timidez quanto a uma hipótese deve ter seu componente retórico considerado. Isto porque a movimentação do crítico em torno deste enigma - a tradição se constitui, mas depois se dispersa - se mobiliza em torno da ideia de formação como perspectiva necessária para se compreender o acúmulo formal brasileiro, mas ao mesmo tempo perspectiva impossível, já que se fala de nossa tradição do ponto de vista de seu corte. Isto, claro, encontra um lastro histórico específico, tornado evidente pelo próprio autor:

O decênio de 1960 foi primeiro turbulento e depois terrível. A princípio, a radicalização generosa mas desorganizada do populismo, no governo João Goulart. Em seguida, graças ao pavor da burguesia e à atuação do imperialismo, o golpe militar de 1964, que se transformou em 1968 de brutalmente opressivo em ferozmente repressivo./ Na fase inicial, período Goulart, houve um aumento de interesse pela cultura popular e um grande esforço para exprimir as aspirações e reivindicações do povo [...]. O golpe não cortou tudo desde logo, mas aos poucos. $\mathrm{E}$ então surgiram algumas manifestações de revolta, meio caóticas, berrantes e demolidoras, como o Tropicalismo. Na verdade, tratava-se de um processo 
transformador que teve como eixo os movimentos estudantis de 1968 e desfechou num anticonvencionalismo que ainda hoje orienta a produção cultural, [...] a busca entre patética e desvairada de uma situação de catch-as-catch-can em atmosfera de terra de ninguém (Idem, p.252, primeiro e terceiros grifos meus).

O papel do Brasil na cultura pós-golpe, percebe-se, se caracteriza pela negação de um padrão tradicional. Mais do que uma simples guinada estilística, o argumento de Candido aponta para a desestruturação do suporte que, em primeiro lugar, tornava possível o agrupamento da tradição em torno de alguns objetos.

Se, como diz Paulo Arantes sobre o trabalho de Candido, existe no conceito de formação um entrelaçamento entre obra, ideal e nó social objetivo ${ }^{7}$, o período militar dispõe em novo arranjo tais elementos, minando a tessitura que os mantinha unidos em sistema. Deve-se supor que o esforço deliberado do governo militar em desbaratar as correntes cultural e politicamente críticas ao regime tenha cooperado para o processo descrito por Candido. Mas mais importante é perceber que o golpe age em tensões produtivas que se saturavam havia pelo menos trinta anos na démarche político-econômica do país. Neste sentido, o período inaugurado pelo regime militar fecha um ciclo de industrialização iniciado em 1930 e, com isto, se dissermos com Arantes, faz vacilar o sentido da formação. A ideia, tão presente nos escritos brasileiros pós-1930, parece perder força após o golpe, levantando a suspeita de que a noção de formação fosse substancialmente animada pelo deslocamento do imaginário sobre o país: de produtor agrícola, passa-se às perspectivas abertas pela industrialização.

A falência de um traço tradicional gera um curioso efeito de realce de um período da história brasileira, pois o caminho conceitual necessário para expor as

\footnotetext{
${ }^{7}$ Cf. ARANTES, Paulo Eduardo; ARANTES, Otília Beatriz Fiori. Sentido da formação: três estudos sobre Antonio Candido, Gilda de Mello e Souza e Lúcio Costa. Rio de Janeiro: Paz e Terra, 1997, p.14.
} 
vicissitudes de uma literatura de difícil acumulação formal se choca, com um golpe, com a constatação de que este processo de acumulação respondia a dinâmicas históricas que podiam ser atacadas e, por fim, submetidas ao jugo de uma ordem em que empenho e cultura caminhassem apartados. A morte da tradição leva consigo a utopia de integração do país através da indústria; mas também promove um olhar crítico aos processos sociais que permitiam a própria sustentação de tal utopia.

Este é o traço que distancia o conceito candidiano dos demais representantes da tradição formativa do pensamento brasileiro. De modo geral, num espectro que alcançava de Gilberto Freyre a Sérgio Buarque de Holanda, de Caio Prado Jr. a Celso Furtado, todos utilizavam a ideia de formação como articulação entre um conhecimento do Brasil real e uma projeção de superação de entraves políticos e sociais, que possibilitaria a conciliação do que chamaremos de 'uma consciência das disparidades sociais e um desejo de integração do país'. É certo que o telos deste processo variou entre um autor e outro: mas, não obstante a diferença de posições, o importante é notar que, entre a apreensão do Brasil real e este telos político, se coloca uma ideia de integração e movimento histórico que, no fundo, acaba conformando o trabalho de cada um dos autores: ou seja, a visualização desta projeção de sentido funciona como farol para o olhar sobre o passado e presente. O caso de Candido, no entanto, é substancialmente diferente ${ }^{8}$.

Isto porque, entre objeto e ideal se interpõe a forma. Deste modo, a relação entre história e sentido, pulsante nos outros autores, fica em Candido condicionada à relação estabelecida pela própria objetividade da obra literária. A atenção aos procedimentos nada usuais de nossa produção em sua relação com a história brasileira

\footnotetext{
${ }^{8}$ Sobre a comparação entre os autores da formação, ver o ensaio "Sobre a Formação da literatura brasileira" In SCHWARZ, Roberto. Seqüências brasileiras: ensaios. São Paulo: Companhia das Letras, 1999.
} 
gera já na Formação da literatura brasileira ${ }^{9}$ uma plataforma de análise que põe sobre a mesa o problema do realismo em contextos heterodoxos. Isto porque o processo de aparição do objeto brasileiro, mostrou Candido, depende de um equilíbrio frágil entre o empenho de uma elite no conhecimento do país e a aparição do objeto brasileiro capaz de atravessar a voz de classe de onde surge a narrativa. Deste modo, pode-se afirmar que a ambição do crítico na Formação é observar os momentos em que a forma literária encampa os processos históricos reais do país através das rachaduras presentes nas ideologias de nação.

A noção de empenho em Candido portanto carrega um sentido ambíguo: é por um lado o impulso que inclina parte das elites dirigentes do país em direção ao conhecimento sobre o Brasil e sua integração à tradição ocidental de pensamento e artes. Mas por outro, o mesmo empenho acaba por constituir uma camada ideológica que se interpõe entre a forma literária e conteúdos históricos. A ideia de formação em Candido nasce assim com um duplo desígnio: por um lado, constitui-se como estudo histórico que mira no caminhar da forma sobre o fio tensionado entre empenho e objeto. Deste modo, compõe-se como uma história da literatura brasileira. Mas ao mesmo tempo, ao pôr-se uma questão formal, joga-se luz precisamente sobre o objeto heterônomo que escapa ao arranjo sociológico entre história e ideologia e dá a ver uma forma em contato direto com conteúdos históricos desviantes - daí, por exemplo, a insistente volta a obras como Memórias de um sargento de milícias.

A atenção à forma heterônoma, que escapa à ideologia, revela a importância da noção de forma na teoria de Candido: a crença portanto na objetividade da obra literária leva o crítico a cunhar algo como um duplo conceito de formação: um positivo, no qual se veem os nexos sociológicos estabelecidos entre classe dominante,

\footnotetext{
${ }^{9}$ CANDIDO, Antonio. Formação da literatura brasileira: momentos decisivos, 1750-1880. $12^{\mathrm{a}}$ ed. Rio de Janeiro: Ouro sobre Azul; São Paulo: FAPESP, 2009.
} 
ideologia e sociedade; e outro negativo. Esta acepção negativa de formação aposta na estrutura da forma como o elemento de análise que expõe os processos sociais e revela a crise ideológica. Deste lugar negativo, a própria forma e sua objetividade tratam de refratar as ligações utópicas que lhes são sugeridas - em alguns casos pelo próprio Candido, que não escapou de uma utopia formativa própria. $\mathrm{O}$ importante neste caso é notar que o arranjo analítico que o crítico arma lega à noção de forma esta negatividade, que chama ao proscênio da interpretação precisamente o nó social objetivo que a escora.

Este traço da obra candidiana por si só mereceria uma análise cuidadosa e independente. Mas no que tange ao nosso interesse imediato cumpre notar que o movimento crítico do autor é o alçamento dos problemas literários à categoria de objeto, que corresponde ao momento em que o nó social objetivo é formalizado: a ideia de nação na Formação, de malandragem na "Dialética da malandragem"10, de acumulação em "De cortiço a cortiço" ${ }^{11}$ e enfim de sertão nos ensaios sobre os regionalistas e em Guimarães Rosa. Isto quer dizer que Candido não encontra por trás do texto o dado que lhe informa: ele rastreia as condições estruturantes para que um tal objeto seja formalizado. Seguindo a mesma lógica, é curioso interpelar a própria rachadura ideológica que Candido mesmo experimenta quando do golpe militar: o esquema do crítico arma-se em favor da pergunta sobre a objetividade da tradição que se coagulou em torno de alguns problemas durante a primeira metade do século XX. A pergunta que resta desta interpelação é: qual chão social Candido viu formar-se sob a forma de um problema social e literário para depois ruir com o golpe?

\footnotetext{
${ }^{10}$ Cf. "Dialética da malandragem" In $O$ discurso e a cidade. 4 a ed. Rio de Janeiro: Ouro sobre Azul, 2010, pp. 17-47.

${ }^{11}$ op. cit, pp.107-132.
} 
O final da Formação aponta para uma resposta. Candido se interessa pelo momento em que a forma assume as rédeas da tradição e confronta-se com este nó social que a sustenta: o caso do escravismo é o que marca o fecho do livro e não é fortuito que o foco recaia sobre Machado de Assis. Escrevendo do seio do colapso da escravatura, a obra madura do autor traduz em forma os elementos que, ao mesmo tempo em que pertencem à ideologia senhorial, mostram-se como a própria face de sua crise. Este sentido de crise deve ser retido da análise de Candido, pois é ele que, para o crítico, qualifica a própria ideia de heteronomia: uma vez que os preceitos escravocratas se encontram em crise - uma vez que eles saem do enquadramento seguro da ideologia senhorial - eles podem ser criticáveis.

A crítica à forma ideológica em crise, torna-se claro, é para Candido o próprio elemento que alimenta a noção da dialética local versus universal (pergunta que o autor repetidamente se faz ao longo do estudo), dado que esta só encontra espaço para acontecer quando há um mínimo descolamento entre o pensamento empenhado das elites e as formas sociais que o criou. No caso de Machado, um descolamento tão pronunciado gerou o vazio ideológico que possibilitou que a forma literária pudesse abarcar a própria ideologia e envolvê-la nos movimentos da produção escravista em crise. Trocando em miúdos, as questões envolvendo a escravidão sempre estiveram em pauta, mas é somente com a crise deste sistema produtivo que eles podem se apresentar como problema formal. Deste modo, o que Machado descobriu e transformou em forma literária não é um problema ético - a saber, a crueldade da escravidão - mas a própria agonia de uma instituição e os volteios ideológicos necessários para salvá-la de sua própria morte.

Isto é, de dentro de uma ideologia funcional uma ideia como a de arbítrio patriarcal em Machado não é motivo de querela. Mas, uma vez em crise, o 
descolamento entre ideologia e sua efetividade torna-se o vão de onde o elemento crítico da literatura pode emergir. Não é à toa, portanto, que Candido fecha a Formação com um elogio ao ensaio crítico de Machado sobre o instinto de nacionalidade: trata-se do reconhecimento da inoperância da ideologia patriarcal na apreensão de um objeto brasileiro, que se apresenta somente quando visto de uma posição em que ela mesmo, a ideologia enquanto ideia de brasilidade, seja observada de certa distância e confrontada com a própria realidade de que se nutre ${ }^{12}$. A visão da crise do sistema escravocrata é, num só golpe, o que permite a quebra do enquadramento romântico da ideia de nação e também o elemento que possibilita o florescimento de uma nova forma para além do romantismo: uma forma que se alimenta precisamente deste elemento heterodoxo, situado entre a base da produção e as ideias sobre o futuro do país.

\section{A emergência do sertão}

O porquê de estas questões necessitarem passar pela literatura é um assunto complexo, mas é o que constitui o fundo do trabalho de Candido em Formação. O que importa aqui notar é que o recorte de Candido importa não só do ponto de vista sociológico, uma vez que mostra que o arranjo político das elites após a Independência exigiram sua posição empenhada na construção de uma ideia de nação que passava pela unidade em torno da mão de obra escrava. Uma vez que este quadro colapsa, a própria noção de empenho é colocada em xeque. Mas Candido vê nesta

\footnotetext{
${ }^{12}$ Os trabalhos de Schwarz sobre Machado cumpriram o papel de perscrutar e dar novos contornos à crítica candidiana. Ver SCHWARZ, Roberto. Ao vencedor as batatas: forma literária e processo social nos inícios do romance brasileiro. $5^{\mathrm{a}}$ ed. São Paulo: Duas Cidades; Ed. 34, 2000 e SCHWARZ, Roberto. Um mestre na periferia do capitalismo: Machado de Assis. $4^{\text {a }}$ ed. São Paulo: Duas Cidades; Ed. 34, 2000.
} 
conjunção de fatores o empuxo necessário para uma reviravolta na tradição. A saber, uma tradição que reconheça o objeto brasileiro enquanto tal, isto é, como um objeto que habita o vão entre as ideologias das elites e a base social heterodoxa do país.

É neste ponto que se admite a importância da emergência do sertão como objeto literário. Da mesma forma como o escravismo nem sempre foi considerado um problema em si, também o interior do país, apesar de habitar desde sempre a literatura brasileira, passou a ser considerado digno de representação por uma conjunção de fatores. Com efeito, o destino dos homens pobres, dependentes e livres surge com frequência em obras de importância. Mas o sertão se forma como objeto apenas na passagem do século XIX ao XX. O contraste no tipo de tratamento dado à questão na comparação de duas obras publicadas no ínterim de algumas décadas assume o papel de exemplo útil a esta hipótese: em $O$ sertanejo $(1875)^{13}$ de José de Alencar e $O S$ sertões (1902) ${ }^{14}$ de Euclides da Cunha o tratamento aos homens livres pobres assume feições e funções muito diferentes na composição dos textos. No primeiro, o destino do sertanejo aparece como peça articulada não só ao enquadramento romântico, mas sobretudo à funcionalidade da ideologia patriarcal. Não à toa o romance se estrutura como rememorações de um antigo patriarca sobre a vida na fazenda do interior do Ceará. Mais importante é no entanto a caracterização de Arnaldo, o vaqueiro-herói, de modo a fazer de sua marginalização na produção um traço de mistério e altivez. Sua altivez todavia tem todos seus feixes direcionados ao centro da ideologia patriarcal, que, embora narrativamente claudicante, comanda a trama e portanto os destinos do herói. Toda sua coragem e bravura direcionam-se à figura do patriarca, à defesa do grupo familiar, ao cuidado à propriedade etc. São estes mesmos feixes que

\footnotetext{
${ }^{13}$ ALENCAR, José de. O sertanejo: texto integral. São Paulo: Editora Martin Claret, 2005.

${ }^{14}$ CUNHA, Euclides da. Os sertões: campanha de Canudos. Cotia: Ateliê Editorial; São Paulo: Imprensa Oficial SP, 2002.
} 
configuram o clímax da trama: o vaqueiro abre mão do amor pela filha do fazendeiro e recebe em troca seu nome de família. Ou seja, ele passa de uma posição de dependente marginal a um dependente legal, se assim pudermos dizer.

Com esta mudança de estatuto legal algumas coisas vêm ao primeiro plano da análise. Tangencialmente a narrativa toca no problema do usufruto da terra por parte dos dependentes rurais - desfrutando de uma situação ambígua entre proprietários e não-proprietários das terras que ocupam na propriedade senhorial - e abre precedente para um elemento chave para a definição da discussão sobre o sertão, que será comentada à frente. Por ora, cabe apenas notar que, como objeto, o sertão não está presente em $O$ sertanejo. Isto porque o drama de Arnaldo enquanto protagonista em nenhum momento escapa da visada senhorial, dando a ver que a propriedade rural, estruturada em torno do trabalho escravo e contando com homens pobres e livres como trabalhadores marginais, tem a prerrogativa de ou absorver este último à casta de dependentes oficiais, mantê-los em sua condição ambígua ou periférica, ou, mais importante, relegá-los à completa escuridão ficcional que é a desvinculação dos laços com a fazenda e sua consequente saída da órbita senhorial. Note-se portanto que, neste caso, a possibilidade de representação literária é igualada à possibilidade de encaixe dentro da lógica da fazenda e, portanto, da posse da terra. Tudo que escapa a esta visada cai numa penumbra narrativa.

A hipótese que aqui se defende é que o objeto-sertão somente emergirá quando este lado obscuro da dinâmica senhorial vier a proscênio. Isto é, quando o dependente da fazenda interiorana escapar da órbita patriarcal tradicional para ocupar esta quina ideológica em que ele deixa de se posicionar como referência ao poder do fazendeiro, mas ainda exerce alguma função ligada à terra. Trata-se de um traço já identificável em Os sertões, no qual o objeto-sertão emerge pouco a pouco, como que 
escapando das tentativas de enquadramento racionalista de Euclides da Cunha. O sertão de Euclides, ao final, emerge quase como um objeto sem face e cuja existência se promove à revelia de todas os nexos causais lançados pelo autor - clima, terra, formação social. Ao longo do livro, vê-se a noção de sertão englobar todos os parâmetros citados e impor-se - com aura até mística - como um estado de coisas que revela uma classe antiguíssima de homens que percorre os interstícios do interior brasileiro.

Vê-se aqui a principal diferença entre este sertanejo e o de Alencar. Ela define o tratamento que se dará à ideia de sertão neste trabalho: com efeito, o sertão que surge como objeto literário no século $\mathrm{XX}$ é tributário à obra de Euclides como o objeto que traça uma linha entre civilização e arcaico de modo a fazer com que o último, nos melhores resultados literários, salte aos olhos do leitor como um objeto estranho, informe, inclassificável. Deste modo, da mesma maneira como ocorreu no caso de Machado de Assis, é preciso que se considere a questão do arcaico menos como um achado dos escritores regionalistas. Assim como as relações patriarcais machadianas, este homem do sertão sempre esteve presente na história do interior brasileiro. A sua transformação em objeto, no entanto, depende da conjunção de dois fatores históricos de ampla ressonância, que têm lugar com a instituição da República no Brasil: primeiro, a paulatina marginalização do destino dos homens pobres livres da estrutura produtiva das fazendas periféricas à cultura do café, nas quais o poder patriarcal é severamente minado. Segundo, uma complexificação significativa dos arranjos das elites dirigentes na definição do curso político e econômico do país após a abolição da escravatura. Ao se jogar luz sobre estas duas tendências será possível perceber como, de certa forma, a ideia de arcaico é um subproduto deste duplo movimento que, em todos os seus sentidos, deve sua substância histórica à passagem 
de um modo de produção baseado na mão de obra escrava para outro dependente da mão de obra livre.

A hipótese que Francisco de Oliveira em “A emergência do modo de produção de mercadorias: uma interpretação teórica da economia da República Velha no Brasil" ${ }^{\prime 15}$ lança sobre o processo de transição do trabalho escravo para o livre vai ao encontro do nascimento do sertão como problema em sentido amplo. Diz o autor, grosso modo, que o fator econômico que comprimiu a escravidão até sua impossibilidade encontra raízes nos próprios desdobramentos do capitalismo europeu, onde a indústria, já inteiramente consolidada como sistema produtivo, via a proporção de capital constante ${ }^{16}$ crescer, transferindo-a aos produtos da manufatura que compunham, aqui, parte dos elementos de subsistência à produção escravista ${ }^{17}$. Em termos menos técnicos, trata-se de afirmar que a proporção de valor, agregado às mercadorias, entre máquinas e trabalhadores havia aumentado no centro do capitalismo, de modo que cada produto de manufatura transferisse maior valor como resultado do avivamento do 'trabalho morto' contido nas máquinas ${ }^{18}$. Como isto afeta a escravidão no Brasil?

Diz Oliveira, sobre a economia brasileira escravocrata, que "na composição orgânica do capital da economia agroexportadora predomina um tipo de capital constante que inclui o escravo, cuja subsistência, também capital constante, força para baixo a taxa de lucro" (FAUSTO, 2006, p.443). Ou seja, sendo o escravo parte

\footnotetext{
${ }^{15}$ Cf. O Brasil republicano, v.8: a estrutura de poder e economia (1889-1930). Fernando Henrique Cardoso... [et al.]; introdução geral de Sérgio Buarque de Holanda. $8^{\text {a }}$ ed. Rio de Janeiro, 2006, pp. 430-455.

${ }^{16}$ A noção de capital constante, no Marx d'O Capital, liga-se à ideia de que, uma vez consolidado o mercado de mão-de-obra livre, é possível à produtividade um salto, uma vez que estes trabalhadores agora se submetem ao ritmo do maquinário industrial. Ver o capítulo 6 de MARX, Karl. O capital: crítica da economia política: Livro I: o processo de produção do capital. São Paulo: Boitempo, 2013.

${ }^{17}$ Cf. op. cit., p.443.

${ }^{18}$ Para uma discussão mais precisa sobre a noção de 'trabalho morto', ver os capítulos 7 e 8 do primeiro volume d'O Capital.
} 
integrante do capital constante - ou grosso modo o 'maquinário' -, a parte relativa a sua subsistência - roupas, comida etc. - faz parte do custo de produção. Sendo grande parte destes itens importada dos centros industriais europeus e norte-americanos, o peso do valor transferido por estes produtos se faz sentir na subsistência dos escravos: "Noutras palavras, é a parte importada do capital constante, a qual toma a forma do fundo de subsistência dos escravos, que ameaça a forma de valor da economia agroexportadora" (Idem, Ibidem).

O grande desafio do capital brasileiro nesta transição do trabalho compulsório para o livre é portanto o de expulsar o escravo do seio da produção, transferindo assim a realização do fundo de subsistência para dentro do país com a criação de um semi-campesinato que se encarregará de produzir os bens da cesta de consumo do trabalhador. Como consequência, esta 'territorialização' do trabalho, como afirma o historiador Luiz Felipe de Alencastro ${ }^{19}$, resulta num estímulo à circulação interna de mercadorias - vestuário, por exemplo, mas não só isso: carne, couro e todo outro tipo de produção que dá sustentação à produção agroexportadora.

Este processo de territorialização do trabalho se dá de forma paulatina e só ganhará uma forma cristalizada com as reformas trabalhistas de Vargas. Mas o que é importante reter deste período da Primeira República é o fato de que as condições para o posterior desenvolvimento industrial do país começam a movimentar-se, ainda que de forma paradoxal. Por um lado, um consórcio horizontal de produção que Francisco de Oliveira não hesita em chamar acumulação primitiva ${ }^{20}$ : isto é, a produção voltada ao abastecimento deste fundo de subsistência do trabalhador e que

\footnotetext{
${ }^{19}$ Cf. ALENCASTRO, Luiz Felipe de. A pré-revolução de 30. Novos Estudos CEBRAP, São Paulo, $\mathrm{n}^{\mathrm{o}} 18, \quad$ p. 17-21, setembro de 1987. Disponível em http://pt.slideshare.net/davi_carvalho/a-pre-revoluo-de-30. Acesso em: 15 abr. 2015.

${ }^{20}$ Trataremos da especificidade do conceito no caso brasileiro à frente.
} 
tem no lastro da terra como fonte de poder para garantir benefícios públicos e angariar trabalhadores (em outras palavras, o próprio fenômeno coronelista). Por outro lado, está a parte dinâmica da produção capitalista incorporada na cultura do café, voltada ao mercado externo.

Vê-se deste quadro que o fim da escravidão gera um rearranjo geral no capitalismo brasileiro. Mais importante para a discussão que aqui se propõe é o fato de que o processo de expulsão do escravo do seio da produção significa a mudança no estatuto da dependência a criação de um tipo particular de periferia, que se caracterizará pelo vínculo ambíguo que este estrato da população manterá com os proprietários de terra à margem da produção cafeeira: vê-se aqui, portanto, $a$ emergência da figura do sertanejo como uma entidade que passa a habitar a quina da ideologia patriarcal. Ainda no mesmo ensaio, Francisco de Oliveira reitera que a realização do valor do café, comercial e financeiramente, em terras estrangeiras gera um impasse para a economia da primeira República. Por um lado, a acumulação cafeeira, vinculada ao mercado externo, sofre com as variações cambiais ao mesmo tempo em que necessita de empréstimos - também estrangeiros - para financiar a própria produção. Deste modo dá-se que a produção do café 'persegue o próprio rabo' uma vez que a realização do valor do produto se dá em sua totalidade em território estrangeiro: mais, torna-se um jogo de soma zero na medida em que o mais-valor do café não se manifesta como lucro, mas como empréstimo. Ou seja, a produção de café pagava para realizar-se externamente sob a forma de juros.

O resultado objetivo desta ciranda produtiva é um quadro paradoxal: a necessidade de manutenção da economia do café redundava não só em sua realização estrangeira, mas numa parca circulação interna de mercadorias e mesmo um impedimento da diversificação social. Como aponta Oliveira, "a classe dominante 
rural bloqueará o avanço da divisão social do trabalho no campo" (Idem, p.452) fazendo com que a hegemonia do café impossibilite a composição das elites periféricas, interessadas na circulação interna de mercadorias, enquanto classe burguesa. Isto é, o arranjo coronelista no fundo é um modo de sobrevivência das elites rurais à margem do café: instadas a suprir uma demanda interna de produtos, mas inibidas em sua vocação manufatureira, resta-lhes o modo de reprodução simples do capital, isto é, a acumulação primitiva:

\begin{abstract}
Fixou-se, em suas relações com o nascente campesinato, numa apropriação do excedente ao nível da circulação via mecanismos de controle político e social já descritos, com o que travou o acabamento da formação camponesa e sua subsequente dissolução. Essa é a origem do controvertido 'feudalismo' das relações agrárias brasileiras. (Idem, p.452, grifos meus)
\end{abstract}

Em resumo, se aponta para o seguinte quadro: a expulsão do escravo do seio da produção gera um seccionamento das elites agrárias do Brasil. De um lado, a elite cafeeira assume a hegemonia sobre o Estado de modo a transformá-lo em seu veículo financiador junto ao estrangeiro. Como se viu, esta estratégia ganha formas de uma acumulação com soma zero, de modo que a elite cafeeira, surpreendentemente, assuma a feição de uma oligarquia anti-burguesa, uma vez que impede a realização de valor internamente e a consequente diversificação social que dela adviria. Nas margens da produção cafeeira, o coronelismo se forma como o sistema que garante a sobrevivência econômica das oligarquias regionais e sustenta a hegemonia cafeeira sobre o Estado. Vistas deste ângulo, as práticas de mandonismo são, no fundo, traduções do imperativo para a reprodução simples do capital, isto é, sua expansão baseada somente na apropriação de terras, trabalhadores braçais e poder político. 


\section{O sertão como excrescência ideológica}

Sem a intenção de exaurir o assunto, retenhamo-nos sobre discussão tocante ao sertão. Como já foi indicado, este emerge como objeto neste processo de 'criação' de uma periferia do trabalho e da expulsão dos meios de subsistência do seio da produção. O quadro é particularmente verdadeiro no que diz respeito ao café ${ }^{21}$; as demais regiões sertanejas apresentam um cenário mais complicado, no qual o imperativo para a reprodução horizontal do capital combinado a uma relativa pobreza de recursos (sobretudo de crédito) promovem não só uma associação parasitária com o poder público como soluções intermediárias para o problema do trabalho. No coronelismo, o homem pobre vê-se ainda vinculado ao fazendeiro, mas não mais como o sertanejo de Alencar: agora, como mão-de-obra para a acumulação primitiva do coronel, que mistura mandonismo ao ímpeto de acumulação de terras e poder. Vêse assim como a ideia de sertão nasce como uma linha que distingue o arcaico do moderno, mas uma linha que nasce ela mesma deste processo de modernização em que relações coloniais de produção são mantidas ou transformadas para sustentar uma débil cadeia acumulativa. Visto desta perspectiva, o sertão emerge não como permanência do arcaico, mas como sua própria fabricação para a sustentação do novo.

Mais importante no entanto talvez sejam as posições ideológicas que, até 1930, lutam pela posse deste objeto. É possível afirmar que também a divisão entre elite cafeeira e elites regionais se replica também no olhar ao sertão: os mesmos

\footnotetext{
${ }^{21} \mathrm{O}$ estudo de Candido sobre as populações rurais paulistas nas décadas de 1940 e 1950 é exemplar neste sentido, tanto no que mostra da pressão para a proletarização rural quanto na resistência da cultura caipira que, em áreas de decadência do café, retorna como 'cicatriz'. Ver CANDIDO, Antonio. Os parceiros do Rio Bonito: estudo sobre o caipira paulista e a transformação dos seus meios de vida. $11^{\mathrm{a}}$ ed. Rio de Janeiro: Ouro sobre Azul, 2010.
} 
traços anti-burgueses observados como resto estrutural da economia do café geram efeitos opostos no espectro ideológico brasileiro. De um lado, o pensamento mais próximo ao café assume seu caráter paradoxalmente avançado e tradicional - a saber, fala-se do setor mais dinâmico da sociedade brasileira mas que, por limitações de sua natureza acumulativa, devem postar-se como anti-burgueses sob o risco de ver a hegemonia paulista colapsar. Fala-se aqui do modernismo paulista e, deste ângulo, o sertão, ou as relações arcaicas de modo mais amplo, são vistos como o traço de informalidade que humaniza o capitalismo brasileiro $^{22}$.

Do outro lado do espectro reside uma seção da população particularmente avivada pela dinamicidade da economia cafeeira: prestadores de serviços, profissionais liberais e burocratas estatais, habitantes das cidades como membros da classe média, fora da esfera de influência dos coronéis no campo, mas cujas carreiras burguesas eram obstadas pela dinâmica geral da economia agroexportadora. Deste lugar, os impasses de um capitalismo frágil são hipostasiados em entraves apresentados por um Brasil dividido entre cidade e interior, avanço e atraso. O sertão emerge aqui como linha demarcatória entre a aspiração burguesa e sua impossibilidade.

O questionamento sobre o atraso surge portanto como nó górdio, colocado em plano ideológico, envolvendo a base produtiva da Primeira República e suas aspirações burguesas contraditórias. Ou seja, o objeto-sertão nasce deste arranjo de forças político-econômicas que ao mesmo tempo em que produz novas relações arcaicas no sertão, projeta-as como imagem sintomática de uma impossibilidade. Por um lado, o arcaico surge como resto simpático que amortece as dinâmicas capitalistas

\footnotetext{
${ }^{22} \mathrm{O}$ ensaio de Roberto Schwarz. "A corroça, o bonde e o poeta modernista" traça um panorama fiel das contradições e dilemas das vanguardas ligadas à aristocracia cafeeira. Ver SCHWARZ, Roberto. Que horas são?: ensaios. São Paulo: Companhia das Letras, 1987, pp.11-28.
} 
nos modernistas, dado que modaliza as vicissitudes da civilização; do outro, para os escritores regionalistas, torna-se um quisto nefasto que entrava o caminho ao desenvolvimento, e que deve portanto ser colonizado.

Quais sejam as pontas deste espectro, o sertão é visto como um outro, um corpo estranho à dinâmica capitalista que dela se forma como excrescência. Cumpre pois notar que a questão do arcaico se coloca no centro do debate sobre o projeto de país fomentado na primeira República, e sua variação ideológica corresponde às diferentes perspectivas de se levarem a cabo processos propriamente burgueses de desenvolvimento. Como se tentou mostrar, esta impossibilidade não se impõe mercê do atraso, mas precisamente porque este último faz parte de um projeto acumulativo de soma zero do café e que em si tem de inibir as dinâmicas burguesas.

A composição ideológica da primeira república fermenta-se pois sobre um terreno instável. No topo da pirâmide social, o aparelhamento do Estado como órgão financiador do principal produto de exportação cria uma estratificação entre as elites cafeeiras e as elites periféricas. Na relação entre as elites e os mais de quatro quintos da população sem acesso a uma cidadania funcional, o sentimento era de que o processo de modernização engatilhado pela abolição da escravatura e pelo aprofundamento das dinâmicas burguesas carreadas pelo café deveria ser ‘amortecido' e controlado a rédea curta pelas elites. O temor, como aponta Florestan Fernandes, era simples:

As representações ideais da burguesia valiam para ela própria e definiam um modo de ser que se esgotava dentro de um circuito fechado. Mais que uma compensação e que uma consciência falsa, eram um adorno, um objeto de ostentação, um símbolo de modernidade e civilização. Quando outros grupos se puseram em condições de cobrar essa identificação simbólica, ela se desvaneceu. A burguesia mostrou as verdadeiras entranhas, reagindo de maneira predominantemente reacionária e ultraconservadora, dentro da 
melhor tradição do mandonismo oligárquico. (FERNANDES, 2005, p.242, grifos meus)

A constituição de um sistema político fechado e altamente reativo - em que ideologia e posse real da hegemonia sobre o Estado coincidem - coaduna com a hipótese já levantada: a de que, compondo-se como uma revolução burguesa frágil, arranjada em função da exportação do café, as elites agrárias no fundo funcionavam como forças de retenção da diversificação da sociedade. O que é importante deter do trecho de Fernandes é a forma como o mandonismo e, mais amplamente, o próprio sistema coronelista agia como sistema original, claramente fundado sobre prerrogativas coloniais, mas cuja efetividade enraizava-se neste pacto intramuros entre as elites. Em outras palavras, os elementos característicos do coronelismo - sua relação violenta frente aos sub-cidadãos da república combinada ao nexo comensal com o Estado - funcionavam como o cimento que mantinha o pacto entre-elites funcional. No que toca especificamente à situação das elites periféricas, é importante notar como o foco recai sobre uma população que é marginalizada dos arranjos coloniais de usufruto da terra mas que persiste como fundamento para uma expansão horizontal da produção voltada ao mercado interno.

O sertão como objeto, portanto, deve seu nascimento a este complexo de forças políticas, econômicas e ideológicas. Do ponto de vista literário, é curioso notar, ainda com Antonio Candido, que em seu ensaio mais importante sobre o assunto “Jagunços mineiros de Cláudio a Guimarães Rosa”, de 1966 - o argumento do autor, interessado na identificação da jagunçagem como objeto propriamente literário, segue o mesmo caminho crítico esboçado alguns anos antes em Formação da literatura brasileira. A saber: muito obstante o tema da violência sertaneja apareça aqui e ali em 
escritos desde o século XVIII, é somente na passagem do século XIX ao XX que ela se impõe como objeto de interesse sistemático da literatura. Isto é, como aponta Candido, é importante que o próprio termo 'jagunço' se estabilize literariamente e seja enfrentado como parte integrante de um sistema efetivo de poder interiorano. Afirma o crítico:

não se consideram jagunços os ladrões de gado, os contrabandistas, os bandidos independentes. Embora haja flutuação do termo, a idéia de jaguncismo está ligada à idéia de prestação de serviços, de mandante e mandatário, sendo típicas nas situações de lutas políticas, disputa de famílias ou grupos (CANDIDO, 2004, p.104, grifos meus)

Mais à frente, quando comenta o romance Chapadão do Bugre Candido nota que a sistematicidade do jaguncismo só pode ser vislumbrada como objeto quando o mandonismo local é confrontado com uma ideia abstrata de Estado e de bem público, em oposição aos interesses privados:

Trata-se da ordem a princípio necessária, na fase de desbravamento, pois assegura através das instâncias privadas, que são principalmente os grupos familiares e suas clientelas, um funcionamento sucedâneo de instituições que o poder público ainda é incapaz de assegurar. A seguir, esta ordem se torna apenas arbítrio, mantendo o parasitismo dos grupos dominantes e impedindo o progresso.(Idem, p.108, grifos meus)

É de suma importância a percepção de que a noção de pitoresco no contexto sertanejo, para Candido, será estruturada em torno do significante abstrato de progresso, em geral posicionado contra as práticas de mandonismo privado. No caso de Chapadão do Bugre, observa-se o mesmo raciocínio presente na Formação: o romance vale pela apresentação documental e até certo ponto realista das relações 
sociais do sertão. Mas peca ao assumir como perspectiva narrativa uma posição ideológica, isto é, ao esposar o ponto de vista da função ideal do Estado e, mais amplamente, da própria civilização no combate a estas práticas. Veja-se assim que o arcaico neste caso não integra o romance de modo a formalizar uma mimese do processo histórico em que o mandonismo representa as próprias limitações internas do progresso brasileiro; ele serve somente como contraponto abstrato para a corroboração de uma ideologia reativa, isto é, uma ideologia que, ao perceber as impossibilidades das dinâmicas burguesas, enxerga no coronelismo as razões do entrave. Daí se compreende a importância que Candido dá ao aparecimento de Guimarães Rosa no cenário literário dos anos 1940 como a 'superação do regionalismo, ${ }^{23}$. Esta superação, mais do que um movimento estético, seria a estruturação da forma em torno do objeto sertanejo já livre das querelas ideológicas plasmadas no pitoresco. A autonomia deste objeto, embora possibilite uma formalização mais afiada, mostrar-se-á mais complicada do que o próprio Candido havia imaginado. Isto porque sua mimese trairá a própria expectativa do crítico quanto à absorção do arcaico à civilização: a autonomia do objeto, neste caso, representará a assunção da face fantasmagórica de ambos os termos desta equação atraso e modernidade.

\section{O sertão como objeto fantasmático}

\footnotetext{
${ }^{23}$ Ver os comentários de Candido sobre Rosa quando da publicação de Sagarana em CANDIDO, Antonio. Textos de intervenção. São Paulo: Duas Cidades; Ed. 34, 2002, p.186. Ver também o famoso ensaio "O homem dos avessos" que trata da estrutura do Grande sertão: veredas, no qual o crítico desenvolve alguns dos temas presentes nas primeiras impressões sobre Rosa. Cf. CANDIDO, Antonio. "O homem dos avessos" In Tese e antitese. $5^{\mathrm{a}}$ ed. Rio de Janeiro: Ed. Ouro sobre Azul, 2006, pp.111-130.
} 
A autonomia do objeto-sertão, como sugerimos anteriormente, permitiria uma visão clara da articulação entre forma, ideologia e projeto político na primeira metade do século XX. Como se viu no caso de Machado, a ideia de crise dos dois últimos ideologia e projeto político - permite que a forma literária seja o fator predominante neste tripé, de modo a englobar formalmente as próprias rachaduras entre projeto político e projeto ideológico e capturar o sentido de totalidade que os subsidia historicamente. Dentro deste mesmo esquadro é possível compreender as movimentações formais do regionalismo brasileiro como fruto dos impasses gerados pelo pacto coronelista. Ou, nos termos de Florestan Fernandes, o empenho da forma brasileira se vê entre os embaraços de um capitalismo difícil, premido entre as promessas de um desenvolvimento burguês e um arranjo acumulativo de soma zero, como é o caso da economia do café.

O sertão como objeto literário emerge portanto como resultado de um paulatino descolamento entre as aspirações ideológicas do país - que, excetuando o caso específico do modernismo paulista, identificava-se a um projeto civilizatório - e uma base político-econômica que perseguia o próprio rabo nos limites do pacto coronelista. Desta perspectiva é curioso interpretar a própria revolução de 1930 mais como um sintoma de impossibilidade de manutenção deste pacto do que um verdadeiro empuxo industrial que, no modelo clássico do desenvolvimento burguês europeu, faria oposição aos enclaves de uma política aristocrática às dinâmicas burguesas. Este caráter estranho e até contraditório da industrialização pós-1930 no Brasil - capitaneado substancialmente pelas mesmas elites agrárias - é o combustível de análises como a de Boris Fausto sobre $1930^{24}$, cujo objetivo é precisamente o de

\footnotetext{
${ }^{24}$ Cf. FAUSTO, Boris. A revolução de 1930: historiografia e história. São Paulo: Companhia das Letras, 1997.
} 
apontar a impossibilidade de se identificar um projeto industrial no seio das forças que alçaram Getúlio Vargas ao poder.

Com efeito, se junto com Francisco de Oliveira podemos supor que a hegemonia do café tinha o cordão umbilical ligado ao sistema de crédito inglês, quando este colapsa com a crise de 1929 o que se verifica é a completa impossibilidade de realização do valor do café ${ }^{25}$. A revolução de 1930, portanto, marca a falência do pacto coronelista - e assim a 'rebelião' de elites periféricas no país - como causa e sintoma de uma grave crise acumulativa. O caráter contraditório da crise ditará as políticas encabeçadas pelo governo varguista: por um lado subsidiar o café como modo de sustentar o único produto que gerava números positivos na balança comercial, por outro intervir diretamente na inércia agrária do país com uma política de liberação de mão de obra para a indústria. Ou, nas palavras de Oliveira,

a nova correlação de forças sociais, a reformulação do aparelho e da ação estatal, a regulamentação dos fatores, entre os quais o trabalho ou preço do trabalho, têm o significado, de um lado, de destruição das regras do jogo segundo as quais a economia se inclinava para as atividades agrário-exportadoras e, de outro, de criação das condições institucionais para a expansão das atividades ligadas ao mercado interno. Trata-se, em suma, de introduzir um novo modo de acumulação, qualitativamente e quantitativamente distinto, que dependerá substancialmente de uma realização parcial interna crescente. (OLIVEIRA, 2003, p.35, grifos no original)

Não cumpre no momento exaurir os sentidos desta afirmação por completo. Cabe por ora notar que uma nova política de realização interna do valor - isto é, a industrialização - dependerá em grande parte da liberação de mão de obra das populações agrárias não ligadas ao café e sobretudo um redirecionamento da ação do

\footnotetext{
${ }^{25} \mathrm{O}$ próprio espetáculo da compra do café para sua queima atesta para esta impossibilidade de realização do valor do produto.
} 
Estado sobre o poder local: ambas as políticas atingindo o coração do coronelismo. Ou seja, o aspecto destrutivo das novas orientações econômicas agirá sobre o elo mais frágil do pacto coronelista, a saber, as mesmas que, na República Velha, lançavam mão do arcaico para equilibrar-se numa estratégia acumulativa frágil. Isto significa, segundo Oliveira, a formação de um novo arcaico que funcionará de base para a industrialização. O novo arcaico, entenda-se, será composto pelo homem do campo pobre, premido pela desorganização dos laços coronelistas e lançado sobre um vazio produtivo.

Os processos sociais que têm início em 1930 apresentam portanto uma dupla face: de um lado, as dinâmicas propriamente burguesas têm suas amarras coronelistas liberadas, o que em termos ideológicos significa a possibilidade de construção de uma sociedade menos estratificada e na qual a ação política se expande para além dos núcleos familiares das elites agrárias. A outra face aponta para o destino destas populações rurais que comporão uma massa trabalhadora jogada ao estado de subcidadania de um processo rápido e desorganizado de proletarização.

No que toca à literatura, as repercussões deste novo arranjo político se fazem sentir no campo ideológico. A destruição dos laços coronelistas libera grande parte da população rural para a composição de uma periferia industrial. O sertão enfim salta aos olhos dos romancistas como objeto autônomo, livre do embate ideológico que o amarrava entre o modernismo e o regionalismo. Ele deixa de ter o caráter de corpo estranho na composição social brasileira, tendo seu nexo com as novas dinâmicas econômicas sendo tecidos: talvez o caso exemplar desta nova visada seja a obra de Graciliano Ramos e em especial Vidas secas, romance que extrai o sumo de seu efeito estético do choque brutal entre o destino das populações rurais e um questionamento radical quanto à possibilidade de construção de uma nação integrada. 
Este empuxo realista sofrido pela literatura brasileira pós-30 guarda portanto as características contraditórias da acumulação periférica: a saber, a sensação que se instala com a abertura de novos horizontes com a debacle das elites agrárias e o 'fantasma social' que ela libera, i.e. uma classe de sertanejos pobres que passam a habitar os interstícios do mundo produtivo brasileiro. No caso de Vidas Secas, por exemplo, Ana Paula Pacheco remete a este fenômeno quando reflete sobre a 'fantasmagoria do mundo do trabalho' em artigo recente ${ }^{26}$. O problema se constitui como pergunta: por que grande parte da atenção realista se volta para o não-lugar do trabalho sertanejo nos anos pós 1930 ? Acredita-se que a resposta a esta questão será formulada novamente como problema alguns anos depois por Antonio Candido: a saber, sobre qual esteira social se funda uma tradição brasileira de literatura?

A resposta já foi aventada: a atenção da literatura aos momentos de crise gera arranjos formais inovadores; a saber, os momentos negativos da formação, em que os imaginários sobre o país perdem sua sustentação material, promovem um empuxo formal sobre as próprias rachaduras do país. Viu-se o caso de Machado como fecho de um ciclo: isto porque a crise da escravidão impossibilitaria uma volta da forma às representações tradicionais; na mesma medida, o projeto de país gestado durante o século XIX, fundado sobre a autoridade e centralidade patriarcais perde o pé de apoio. Com efeito, o que se encontra no autor é um curto circuito utópico-ideológico inimaginável nos anos de bonança do Império. Mas se a ideia de formação da literatura não é somente um retrato ideológico, pode-se afirmar que o conceito se sustenta enquanto pergunta feita ao arranjo entre elites governantes, base produtiva e forma literária. Neste sentido, o período compreendido entre 1930 e o golpe militar de 1964 mostra-se de fundamental interesse para o pensamento sobre a literatura e, mais

\footnotetext{
${ }^{26}$ PACHECO, Ana Paula. O vaqueiro e o procurador dos pobres: Vidas secas. Revista do Instituto de Estudos Brasileiros, Brasil, n.60, p.34-55, abr. 2015.
} 
especificamente, sobre a ideia de tradição que, se por um lado se fundou com o interesse das elites em pensar o próprio país, abriu as portas para o realismo quando o arranjo das mesmas se vê debilitado. O sentido de crise que é proposto neste caso é todavia mais agudo do que aquele observado por Machado: isto porque envolve, em torno de uma tradição, uma expectativa de que os próprios aspectos que definem esta tradição (a saber, um olhar formal-objetivo às rachaduras sociais do país) sejam encampados pelo próprio movimento integrador que promove a tradição mesma. Existe, portanto, uma perspectiva de que o realismo dê uma volta em si mesmo - a um só tempo liberando as verdades do processo e superando-as.

O que as declarações de Candido sobre o descenso da tradição revelam é que durante três décadas, de 1930 a 1964, a crise das elites e seu rearranjo forjou um momento sui generis na esfera literária, no qual os encontros e desencontros entre uma utopia de integração do país sob a indústria e o destino do homem pobre eram fermento para o realismo brasileiro. O ponto de vista da desagregação tanto da tradição realista quanto das expectativas ligadas a ela gera uma interessante perspectiva do ponto de vista crítico: se mantivermos aberta a hipótese de que um nó social objetivo deve ser extraído formalmente deste processo, devemos aceitar que o realismo existiu, mas não completou o movimento que se esperava dele: não porque foi insuficiente, mas porque as torrentes históricas que o mobilizavam jogavam-no ao lado do utopia formativa ao mesmo tempo em que roía a corda onde se equilibrava. Ou seja, talvez a tradição literária estivesse à frente do pensamento conceitual na percepção de que o processo que integrava o país sob a indústria tinha uma face positiva e outra negativa, habitando o mesmo espaço histórico, de modo que o nó social a ser absorvido pela forma fosse precisamente esta aporia. Noutras palavras, a tradição formativa armou a estrutura crítica para que pudéssemos analisar o período; 
mas sua debacle histórica torna-se ainda mais importante, pois o desligamento da forma de suas projeções utópicas obriga-nos a supor que seu empuxo histórico colocava-se concomitantemente dentro e fora do processo de formação do país.

Como se tentou mostrar, a questão do sertão emerge como marca d'água deste novo processo, e o arranjo que ele oferece como objeto é notável. A bem notada 'fantasmagoria' do mundo do trabalho no realismo brasileiro é um tópico ainda a ser perscrutado, mas resta como indicação de que a tradição da literatura se coloca frente a um processo profundo de transformação de nossa base produtiva, de destruição de antigas formas de associação entre elites e trabalhadores e mesmo intraelites. O frágil muro erguido pela Primeira República sobre o pacto coronelista paulatinamente se esgarça para abrir caminho à indústria: o que salta aos olhos da literatura é o resto deste processo, o necessário fantasma do sertanejo. Talvez mais importante do que isto, no esquadro das perguntas levantadas neste texto, seja a ideia de que o estudo deste objeto - o sertão - lega uma questão fundamental ao realismo brasileiro ao interpelá-lo com o seguinte cenário: a superação do 'atraso', sua destruição, abre sulcos que possibilitam a transformação econômica do país; mas, ao contrário do realismo europeu, sobre estes sulcos não correm os processos de formação do sujeito moderno. Vê-se somente o fantasma do sertanejo, que sobra como resto ou outro de ambos os polos da equação: fantasmagoria do mundo coronelista, fantasmagoria do mundo industrial.

A compreensão da emergência do sertão como tópico ajuda a responder a questão: trata-se de uma contradição latente que acaba por penetrar as melhores obras brasileiras do período. Como em Vidas Secas, o trabalho pode ser um fantasma e ao mesmo tempo dominar a vida das personagens. Ainda mais reveladora é a questão levantada sobre Guimarães Rosa, tido como Candido como o fecho desta tradição: 
como um objeto que surge timidamente em Euclides da Cunha pode tomar conta de uma obra da envergadura de Grande sertão: veredas? A resposta para estas perguntas deve passar pela consideração dos traços peculiares da tradição literária brasileira e sua relação com processos sociais que procurei delinear neste capítulo. É fundamental que passemos agora, no entanto, à análise dos processos básicos na narrativa rosiana que evidenciam a captura deste objeto: o sertão autônomo mostrar-se-á, nos textos de Sagarana, como um objeto que afeta profundamente a forma de Rosa. Sua dupla historicidade - o sertão na Primeira República, o sertão pós 1930 - revelará os dois níveis básicos em que o objeto se movimenta: um primeiro, em que o mundo coronelista é apresentado como fratura - ou onde o arcaico revela sua compressão -; e um segundo, em que o sertão transforma-se em entidade própria, transbordando suas fronteiras, engolfando as vozes que sobre ele falam, mostrando suas relações com outras esferas da sociedade.

Se, com Adorno, pudermos afirmar que "o especificamente artístico na arte deve ser concretamente derivado de seu outro" e que "somente isto responderia às demandas de uma estética materialista-dialética" (ADORNO, 1996, p.3) 27 $^{27}$ e se o sertão oferece um outro tanto à utopia de integração que figurou no pensamento brasileiro após os anos 1930 e, no limite, à própria ideia de tradição literária (uma vez que agrupa seus interesses numa rachadura social), voltamos à afirmação inicial de Candido de um outro ângulo. O desfazimento da tradição que se observou após o golpe pode ser explicada pela formalização do sertão como objeto literário, na figura de Guimarães Rosa. Esta assunção, um tanto paradoxal, mostra duas faces: trata-se do fim da formação pois a ditadura militar soterrou qualquer utopia de integração

\footnotetext{
${ }^{27}$ Tradução livre da edição norte-americana: "The specifically artistic in art must be derived concretely from its other; that alone would fulfill the demands of a materialistic-dialectic aesthetics".
} 
democrática do país; e do ponto de vista literário, a relação entre este outro-sertão e a utopia de que um dia este não-sujeito virasse do avesso é o que mantinha a chama realista dos decênios pós-1930 acesa. A formalização, portanto, deste avesso mesmo a reversibilidade de uma forma que passa do positivo ao negativo incessantemente já é sinal de que a superação utópica é impossível, restando apenas uma imagem em negativo do processo da morte da utopia.

Esta morte, no entanto, é para a crítica como a morte de Diadorim em Grande sertão: veredas: uma fissura que, ao demandar constantemente o retorno a este corte, pergunta-lhe sobre suas necessidades, remodelando-a. O olhar direcionado a este fantasma do sertão torna-se portanto imperativo para a própria noção de crítica da literatura brasileira. Se a crítica e o pensamento brasileiro desejou tanto a formação, esta mirada ao avesso do objeto, representado pelo sertão, pode ser fundamental para a própria crítica dos nossos sintomas quando da morte de nossa utopia. 


\section{A volta do marido pródigo}

A segunda novela de Sagarana, "A volta do marido pródigo", condensa diversos elementos ficcionais que se mostrarão presentes não só no livro de estreia de Guimarães Rosa, mas também formarão a espinha dorsal de escritos posteriores do autor. Trata-se de uma novela cujo mote - a malandragem - é facilmente identificado e, precisamente por tocar num topos corrente em nossa tradição literária, promove um efeito de adesão quase imediata, sem muitos problemas, ao corpo da ação, ao tom da narrativa e a sua personagem principal. O desafio crítico diante do texto se mostra portanto uma ação de dupla face: aceitar seu tom leve e divertido como um dado, mas rejeitá-lo em seu nível estrutural. Isto é: o primeiro passo no enfrentamento de "A volta do marido pródigo" deve ser reconhecer e evidenciar uma estrutura contraditória, na qual a própria fibra solta da ação malandra testemunha e até age contra si ao apontar para um plano narrativo que somente ao final do texto se mostra presente. Em termos mais claros, dir-se-ia que a malandragem é pintada como afresco sobre um mural que lhe é extemporâneo. Mas, ao contrário do exemplo pictural, a sobreposição não é revelada com a passagem do tempo ou com o uso de outros materiais: a malandragem pertence ao tecido da novela, mas sua própria ação, por mais envolvente que seja, age contra si ao evidenciar um movimento na estrutura da 
forma que a contradiz ao mesmo tempo em que a conforma. Numa palavra: a malandragem é leve e descompromissada, e no mesmo ato de sê-lo, é também seu oposto. Voltaremos a esta tese ao final da análise.

A primeira etapa para a demonstração desta hipótese deve partir do dado mais visível ao leitor da novela: a saber, o fato de que, não obstante a trama relativamente simples - o foco narrativo sempre presente no acompanhamento da personagem Lalino, suas ações, planos e 'contraplanos' -, a narrativa se mostra dividida em duas partes. Isto é, tem-se uma estrutura textual que funciona até a partida de Lalino para o Rio de Janeiro e outra que dá conta de sua volta ao interior de Minas e dos eventos que lhe sucedem. Ainda que o tônus das ações de Lalino não sofra nenhuma mudança com o passar do tempo - mostrando que a personagem se encaixa na tradição malandra brasileira ao apresentar uma subjetividade inerte ao acúmulo processual algo muda quando Lalino retorna e se encaixa na engrenagem política do coronelismo interiorano. Esta análise tentará se haver com os indícios textuais que apontam para uma aparente estrutura disjuntiva da narrativa - a saber, dois registros diferentes em que a malandragem é exposta e colocada para funcionar. Deste modo, espera-se ao final chegar-se a uma visão unificada da novela, não obstante sua aparente fratura.

O primeiro aspecto que deve chamar a atenção do leitor é a apresentação da narrativa em atos, numerados pelo narrador. O primeiro destes atos encerra e demonstra sua função: a saber, uma relação específica com a passagem do tempo narrativo e sua relação com as ações de Lalino. Vejamos como isso se dá: o texto se abre com marcações secas de tempo e eventos:

Nove horas e trinta. Um cincerro tintila. É um burrinho, que vem sozinho, puxando o carroção. Patas em marcha matemática, andar conscensioso e macio, ele chega, de sobremão. Pára, no lugar justo onde tem de parar, e fecha imediatamente os olhos. [...] Pronto. $\mathrm{O}$ 
preto desaferrolha o taipal da traseira, e a terra vai caindo para o barranco. Os outros ajudam, com as pás. Seis minutos: o burrinho abre os olhos. O preto torna a aprumar o tabuleiro no eixo, e ergue o tampo de trás. O menino torna a pegar na rédea: direita, volver! Agora nem é preciso comandar: - 'Vamos!'... - porque o burrico já saiu no mesmo passo, em rumo reto; e as rodas cobrem sempre os mesmos sulcos no chão. (GUIMARÃES ROSA, 2001b, p.99-100, grifos meus $)^{28}$.

A apresentação da cena e o posicionamento do narrador são inequívocos: trata-se de um ambiente de trabalho, em que a passagem do tempo é marcada por atos repetitivos que envolvem as ações tanto de homens quanto de animais num objetivo comum. Este objetivo comum, torna-se claro mais à frente, é a construção de uma rodovia que liga Belo Horizonte a São Paulo. A abertura do ato, portanto, joga o leitor diretamente numa cena que lhe é estranha, sem nenhuma introdução da parte do narrador. Pelo contrário, sua atitude é propositalmente factual e distante, sugerindo a sensação de que a ação lhe é independente. Isto é, ela já acontecia antes de sua chegada e antes do propósito de narrá-la e provavelmente continuará a acontecer, sob o ritmo das repetições, a despeito do narrador. Este portanto porta-se como um observador contingencial, cujo interesse, torna-se claro, não recai sobre a matéria da produção: a saber, não se trata de adentrar o porquê da construção da via de rodagem, como ela se estrutura, de onde vieram estes trabalhadores etc. O ambiente de trabalho serve como pano de fundo para uma apresentação minimamente necessária para o entendimento do contexto narrativo:

No corte, a turma do seu Marra bate rijo, de picareta, atacando no paredão pedrento a brutalidade cinzenta do gneiss. Bom trecho, pois, remunerador. Acolá, a turma dos espanhóis cavouca terra mole, xisto talcoso e micaxisto; e o chefe Garcia está irritado, porque, por causa

\footnotetext{
${ }^{28}$ Evitando a repetição da referência bibliográfica, usaremos 'S' para Sagarana nas próximas citações, todas extraídas da mesma edição da obra.
} 
disso, vão receber menos, por metro quadrado e metro cúbico. Adiante, uns homens colocando paus em mata-burro. Essa outra gente, à beira, nada tem conosco: serviço particular de seu Remígio, dono das terras, que achou e está explorando uma jazida de amianto. E, mais adiante, o pessoal do Ludugéro, acabando de armar as longarinas da ponte. (S, p.100, primeiro, segundo e quarto grifos do autor, terceiro grifo meu).

Note-se neste trecho que o narrador resume-se somente a explicar ao leitor o que ele vê: como observador de fora, ele não adentra a produção, apenas a apresenta como alguém que sabe informações básicas do que ocorre: quem comanda o trabalho de quem, qual o tipo de trabalho que se está presenciando, qual deles é mais rentável. Desta apresentação, é de fundamental importância que se note que o narrador circunscreve a cena de trabalho de uma posição de fora: mesmo as emoções do chefe Garcia, por exemplo, que comanda os espanhóis, são vistas como decorrência da matéria do labor em si, ou seja, sua frustração é quase decorrência natural da exploração de uma parte menos lucrativa da construção. O narrador ainda faz questão de dar nota de uma parte exterior à cena interessada quando afirma que aquele pessoal que se vê por ali, extraindo amianto, nada tem a ver com o trabalho que lhe interessa. Ou seja, todo o esforço do narrador se dá no sentido de apresentar a construção da rodovia como algo com motivos e funcionamentos próprios, como um corpo estranho ao lugar e cuja lógica não só é autocontida como não lhe desperta muito interesse.

A importância da apresentação da cena in acto torna-se clara quando Lalino Salãthiel dá as caras no meio do expediente, escorregando do compartimento de carga de um caminhão em movimento que chegara com produtos vindos do armazém. A chegada de Lalino dá ensejo a um gesto fundamental do narrador: ele anota o tempo novamente, afirmando que "agora seu Marra fecha a cara" (S, p.101, grifo no original) com a chegada atrasada do empregado; segue-se uma breve descrição da 
aparência pitoresca de Lalino e, a partir deste ponto, a narrativa se abre aos diálogos entre as personagens. O agora que marca o momento de sua entrada em cena será, até o fechamento do primeiro ato da novela, a brecha de que o narrador se aproveita para abrir a célula do trabalho a uma perspectiva interna, animada unicamente pela ação de Lalino, que desperta as reações nos companheiros de trabalho e que são de fato de interesse do narrador: “Os colegas põem muito escárnio nos sorrisos, mas Lalino dá o aspecto de quem estivesse recebendo uma ovação:/ - Olá, Batista! Bastião, bom dia! Essa força como vai?.../ Boa tarde!” (Idem, Ibidem). Mais adiante, o narrador deixa clara sua intenção ao desviar a atenção da cena abrindo um importante parênteses; um diálogo na periferia da cena: “(Lá além, Generoso cotuca Tercino:/ - Mulatinho descarado! Vai em festa, dorme que horas, e, quando chega, ainda é todo enfeitado e salamistrão!....)" (Idem, Ibidem).

O desprendimento do narrador, que pode ir e voltar à cena principal, como se vê, serve a um propósito. Se colocado em contraste com seu posicionamento inicial, sua perspectiva denotativa está de acordo com seus movimentos posteriores, seguindo os rastros de Lalino; mesmo sua relação com o tempo obedece à atenção à personagem principal: um tempo frágil mas cuja inconsistência lhe propicia a abertura a ações concomitantes, todas elas despertadas por Lalino. O narrador constrói uma posição de modo que os movimentos de Lalino gerem um efeito de choque com o mundo do trabalho; isto é, a malandragem, que logo nas primeiras páginas da novela se configura como seu objeto, não é introduzido como objeto autônomo: ela recolhe sua substância necessariamente de sua relação com a disciplina exigida no trabalho assalariado; mais especificamente, o trabalho tal como é descrito pelo narrador ${ }^{29}$ : a

\footnotetext{
${ }^{29}$ À frente ver-se-á a importância da caracterização do trabalho na construção da estrada como um evento autocontido, passageiro e relativamente independente das demais relações sociais do interior mineiro.
} 
saber, neste caso, um trabalho que acompanha a construção dos trechos da estrada e que portanto alicia mão-de-obra por onde passa. Este aspecto do trabalho, sua transitoriedade, é fundamental para o entendimento do vão que se estabelece entre a disciplina demandada para a efetuação das tarefas e as manobras de Lalino para burlála. É precisamente neste vão que se constitui a malandragem em "A volta do marido pródigo", e é também através deste espaço que o narrador constrói sua perspectiva e, desta forma, acompanha o ziguezaguear de Lalino, como se vê no seguinte trecho:

\begin{abstract}
Bom dia, seu Marrinha! Como passou de ontem?/ - Bem. Já sabe, não é? Só ganha meio dia./ E seu Marra saca o lápis e a caderneta, molha a ponta do dedo na língua, molha a ponta do lápis também, e toma nota, com a seriedade de quem assinasse uma sentença. [...] Que é que eu hei de fazer, seu Marrinha... Amanheci com uma nelvralgia... Fiquei com cisma de apanhar friagem.../ [...] Mas o senhor vai ver como eu toco o meu serviço e ainda faço este povo trabalhar... (Idem, p.100-101, primeiro grifo no original, segundo grifo meu).
\end{abstract}

O narrador posta-se na brecha entre a célula do trabalho assalariado, que exige disciplina e manejo racional do tempo, e a malandragem de Lalino, que com ela se choca, aproveitando-se dos restos deste choque. Somente deste ponto de vista é possível construir a ironia que guia a negociação entre Lalino e seu Marra quanto ao pagamento das horas de trabalho do primeiro: a seriedade de sua sentença na anotação das horas trabalhadas por Lalino é rapidamente desfeita pela lábia do trabalhador que, ao desviar a atenção de seu supervisor para a elaboração de um teatrinho local, consegue que este revise sua sentença e lhe garanta o pagamento do dia pleno de trabalho. O narrador faz jus a sua posição, pois durante toda a 'negociação' abre-se espaço, sem qualquer mediação, para o mesmo parênteses que já antes aparecera, no 
qual são mostrados ao leitor os comentários dos outros trabalhadores sobre Lalino, cujo conteúdo é precisamente o choque entre labilidade e disciplina. A possibilidade desse vaivém entre ações dispersas num único ambiente evidencia como ao narrador é permitida uma entrada nesta lacuna através da malandragem.

Há, portanto, neste primeiro ato da novela, um número significativo de movimentos formais que aproximam o narrador de sua posição desejada. A partir do momento em que Lalino entra em cena, a narrativa comporta-se de fato de acordo com a arquitetura de um teatro: o tempo paralisa-se e a cena de trabalho, antes estéril, abre-se para uma multiplicidade de vozes cujos vetores apontam todos para o mesmo centro: a malandragem. A voz narrativa acompanha este movimento, mas de maneira a explicitar que este centro não é de modo algum estável, dependendo da agitação proporcionada pela personagem principal. O que se tem pois, neste momento da trama, é um ziguezague que assinala o núcleo mole do trabalho assalariado neste contexto específico.

A narrativa poderia se contentar com isto, a saber, com a simples exposição da malandragem como inadequação do trabalhador interiorano ao mundo do trabalho assalariado $^{30}$. Seus movimentos seguintes, no entanto, mostram que sua ambição é mais ampla. A partir da caracterização da malandragem e do posicionamento do narrador em função dela, o que se vê é a abertura desta célula do trabalho que antes se mostrava distante e inacessível. Mais importante é que esta abertura serve para a caracterização deste mundo do trabalho de dentro e a partir do vão aberto pela malandragem. Tudo isto acontece via Laio e sua tagarelice que, precisamente por ser antidisciplinar, instiga dois procedimentos básicos através dos quais notações importantes são recolhidas pelo leitor como desvios da pura repetição do trabalho

\footnotetext{
${ }^{30}$ É este o núcleo do argumento de Nildo Benedetti em O Brasil de Rosa. Tocaremos nas consequências desta visão da malandragem à frente.
} 
manual. São eles os diálogos entre os trabalhadores e as fantasias de Lalino, ambos vinculados um ao outro e que servem à expansão da cena laboral para outros espaços do universo sertanejo.

Vejamos um exemplo claro deste procedimento. Laio provoca um companheiro, criticando a maneira como ele trabalha. A provocação abre espaço para o diálogo e, depois, a fantasia:

- Xi, Corrêia!.../ - Que é, comigo?/ P'ra que é que você põe tanto braço no braçal? Com menos força e mais de jeito, você faz o mesmo serviço, sem carecer de ficar suando, pé-de-couve no chuvisco!/ - É... Mas, muito em-antes de muita gente nascer, eu.../ - Você já penava que nem duas juntas de bois, p'ra puxar um feixinho de lenha, não é, fumaça?... Qual, eu estou é brincando... (Corrêia tinha feito uma cara ruim) Lá até que é um arraial supimpa, com a igrejinha trepada, bem no monte do morro... E as terras então, hein, Corrêia?! P'ra cana, p'ra tudo! (Corrêia se praz)... Eu acho que nunca vi espigas de milho tão como as de lá.../ - É. A terra é boa.../ - Caprichada! E ainda estou por conhecer lugar melhor para se viver [...]. Ah, eu inda hei de poder arranjar dinheiro p'ra comprar uns dez alqueires ali por perto, só de mato-de-lei... (S, p.103, grifo no original).

Note-se que as provocações de Laio são antiprodutivas e anticonstrutivas. Isto é, atrapalham o trabalho e não levam a lugar nenhum como função subjetiva: as personagens não são afetadas em sua realidade como assalariados, nada muda em suas perspectivas sobre o trabalho em que se engajam. A única coisa que o diálogo acessa, sobretudo com a menção de Lalino à terra de Corrêia, é a fantasia da posse da terra, da agricultura fértil e consequentemente uma saída da situação em que se encontram naquele momento. O devaneio, não obstante, informa-nos sobre o passado de Corrêia: sabe-se a partir dele que o trabalhador saiu de algum canto de Minas Gerais no qual o 
contexto rural de produção prevalece sobre qualquer coisa que remotamente caracterize o trabalho assalariado.

A fantasia de Laio, completamente irresponsável no que diz respeito à fidelidade histórica, subverte a construção inicial do narrador, em que o trabalho na estrada aparece como um célula laboral asceticamente fechada sobre si. A pura representação de seu desejo, sem nenhum lastro e por isso pura provocação, retraça o caminho do trabalhador do desenraizamento rural ao trabalho assalariado. Como lugar social, portanto, é possível afirmar que a fantasia de Laio - uma das manifestações de sua malandragem - é uma imagem positivada de um processo fundamentalmente negativo, que neste momento ainda aparece como uma relação obscura entre o trabalho assalariado e a interrupção do trabalho rural, fosse ele de subsistência ou de lida em fazenda alheia. Como consequência, é interessante notar que as ações malandras abrem caminho para a descoberta do lugar de nascimento da própria malandragem, mostrando-se assim não como algo em si - a malandragem como qualidade inata do sertanejo - mas como função de tenacidade do trabalho assalariado (neste caso, uma baixa tenacidade, ainda que existente). Funcionando então como alternador, a malandragem positiva - em fantasia - retira seu tônus daquilo que é um processo social essencialmente negativo $-\mathrm{o}$ desenraizamento rural. $\mathrm{O}$ mais importante é notar esta posição relacional da malandragem: não se trata de um corpo estranho ao trabalho livre e assalariado, mas precisamente um ponto de afrouxamento que denota sua existência.

A noção de desenraizamento é importante na contextualização do que é propriamente o nascimento do moderno mercado de trabalho no Brasil: a saber, o que Luiz Felipe de Alencastro ${ }^{31}$ caracterizou como transição de uma estrutura produtiva

${ }^{31}$ Cf. ALENCASTRO, op. cit. 
que 'comia trabalhadores crus', isto é, valia-se da escravidão e sobretudo do lastro com a terra para manutenção e reprodução de mão-de-obra, para outra estrutura que só se cristalizaria após os anos 1930, na qual a nascente produção industrial necessitava do 'cozinhar' dos trabalhadores. A diferença residiria na maneira como se dispõe a mão-de-obra à produção de mais-valor: o trabalho 'cozido internamente' depende do fluxo interno de mão-de-obra entre setores da economia brasileira e, mais importante, que pode gerar excedente de mão-de-obra; em oposição à crueza do trabalho forçado, o trabalho cozido é aquele que se sustenta sobre a possibilidade de assalariamento. Isto é, que o salário seja portador de valor e, assim, por um lado, garanta que o mais-valor seja extraído numa relação entre tempo e trabalho e, por outro, tenha no horizonte a transformação de terra não mais em equivalente de poder, mas em meio de produção, abandonando o nexo colonial que assegurava a autonomia produtiva e jurídica de cada latifúndio. Ou seja: o que ficará mais claro com o avanço da discussão é que esta transformação na chave produtiva não é apenas uma troca do tipo de mão-de-obra. Ela envolve também um deslocamento do centro de poder do latifúndio com traços coloniais para outro lugar, mais difícil de ser localizado pois é o lócus de própria atuação do capital. Mas, dizendo em termos simples, se de um lado o 'cozimento' do trabalho significa o desenraizamento do trabalhador - e consequentemente uma errância laboral e um obstáculo às práticas de subsistência não vinculadas ao mercado -, de outro tem-se sob a figura do fazendeiro a corrosão da identificação entre posse de terras e poder e sua inserção na cirando do capital.

Voltaremos a este tópico mais à frente. O que importa dizer neste momento da análise é que o aparente desprendimento de Lalino, a nosso ver, deve-se à ocupação desta posição histórica de transição do trabalho cru ao cozido. Isto porque, se o enredamento do trabalhador rural na prática assalariada depende de dois fatores - a 
possibilidade de transformação do dinheiro em mercadorias, ou seja, o salário como portador de valor, que possibilita o segundo fator, o desenraizamento das práticas de subsistência - o cenário apresentado por "A volta do marido pródigo" é manco de uma destas pernas. A saber, tem-se uma ideia muito vaga do uso do dinheiro recebido como pagamento da rodovia, por exemplo. Isso não significa que o dinheiro não tenha nenhuma função neste quadro: ele o tem muito antes da consolidação da produção industrial no país. Mas não é possível ver como a necessidade de salário exerce uma função coercitiva e decisiva sobre os trabalhadores no que diz respeito à efetiva metamorfose do dinheiro em mercadorias. O dinheiro, assim como as fantasias de Lalino, aparece como um significante solto, não costurado a uma rede de necessidades básicas que propriamente caracterizam o mercado capitalista.

Não é à toa, portanto, que as fantasias sobre o dinheiro, em Laio, sejam descoladas de qualquer traço real, sendo facilmente permutáveis entre a compra de uma terra onde tudo que se planta dá - "Mas hei de plantar também uma chácara, como ninguém não viu, com as qualidades de frutas... Até azeitona!” (S, p.104) - e prostitutas -

Em nem sei como é que vocês ficam por aqui, trabalhando tanto, p'ra gastarem o dinheirinho suado, com essas negras, com essas roxas descalças... Me dá até vergonha, por vocês, de ver tanta falta de ter progresso! [...] Cada lourinha, upa!... As francesas têm olho azul, usam perfume... [...] E é só ‘querido' p'ra cá, 'querido' p'ra lá... A gente fica até sem jeito... (S, p.107).

É muito significativo, para a tese aqui proposta, que a manifestação do uso do dinheiro, para Lalino, se dê nas fantasias de posse de terra e gasto com prostitutas. De um lado, o uso do dinheiro liga-se negativamente ao desenraizamento do trabalho rural (ou seja, exerce uma função compensatória com aquilo que se perdeu) e por outro mostra-se como desejo solto, sem objeto, mirando em devaneios sobre mulheres 
que há na capital do país, à espera da transformação do salário em prazer, uma ideia vaga e irônica do uso 'inteligente' do dinheiro.

A malandragem de Lalino indica portanto a habitação de um lugar muito específico na história brasileira. Sua própria possibilidade, seu ativo desprendimento em face da disciplina exigida pelo trabalho assalariado, mostra como este trabalho está desconectado de uma rede de necessidades que se esperaria se o salário fosse portador de valor. Isto se torna claro quando, já no terceiro ato da novela, o narrador lança o olhar sobre o vácuo deixado pelo término da construção daquele segmento da estrada: "E assim se passou mais de meio ano. $\mathrm{O}$ trecho da rodovia ficou pronto. $\mathrm{O}$ pessoal de fora tomou rumo, com carroções e muares, famílias e ferramentas, e bolsos cheios de apólices, procurando outras construções" (Idem, p.117, grifo meu). Neste ponto vê-se claramente o porquê de o narrador, ao início, focar na construção como um objeto estranho e autossuficiente: o investimento do Estado, na construção da via de rodagem, carrega consigo seu próprio 'saco de trabalhadores' que, em troca de seu trabalho, recebem algo vago como apólices ou títulos da dívida estatal; isto é, algo que, diferentemente do dinheiro, não pode ser transformado sem um número de mediações, no ato de troca, em mercadoria como comida, casa etc. Há, neste caso, trabalho assalariado; mas ainda faltam-lhe as mediações sociais necessárias para se constituir como trabalho propriamente capitalista, em que o dispêndio de tempo de trabalho possa ser expresso em portabilidade de valor ${ }^{32}$. Não à toa, portanto, passada esta bolha assalariada, o local volta a se fechar sobre as formas rurais de produção: "Mas os espanhóis ficaram. Compraram um sítio, de sociedade. E fizeram relações e

\footnotetext{
${ }^{32}$ Moishe Postone, em sua interpretação de $O$ capital, chama a atenção para a dominação abstrata do capital sobre o trabalho como o fator mais importante da produção capitalista. Ver mais em: POSTONE, Moishe. Tempo, trabalho e dominação social. São Paulo: Boitempo, 2014.
} 
se fizeram muito conceituados, porque, ali, ter um pedaço de terra era uma garantia e um título de naturalização" (S, p.117).

A novela, com isso, passa a apontar para sua segunda metade. Esta passagem, no entanto, deve ser mediada por um comentário ao texto que fundou a crítica sobre a malandragem brasileira e que pode esclarecer pontos desta análise. O escrutínio detalhado da "Dialética da malandragem" de Antonio Candido é desnecessário, dado o número de estudos sobre o texto e mesmo a tradição crítica que iniciou. O que interessa particularmente a esta discussão é uma visão da malandragem que sofre uma mudança radical do comentário sobre as Memórias de um sargento de milícias contido no livro de 1959, Formação da literatura brasileira, se comparada à sua revisitação em 1970 no ensaio citado acima. Na Formação, a rápida anotação sobre o livro oitocentista segue a lógica do estudo do árduo processo de formação de nossa literatura: Candido chama a atenção para o caráter excêntrico do romance, a fuga da grandiloquência romântica da época e o foco no achado documental do texto, isto é, ao retrato da sarabanda da vida fluminense no período joanino. No que tange ao já conhecido esquema do crítico, o interesse na dialética local x universal, as Memórias são de interesse para Candido por trazer à forma uma imagem de um objeto livre das amarras de tom do romantismo da época. Neste sentido trata-se de um livro importante para o reconhecimento da diferença que envolve o objeto brasileiro na literatura. Ou seja, a malandragem, no caso do estudo de 1959, é subsumida a seu aspecto documental - a saber, à possibilidade de se formalizar o caráter inteiramente desviante da vida brasileira. Por isso o livro merece estar no rol de obras que 
demonstram o percurso da formação: por gerar uma visão da hetoronomia que seria, na opinião de Candido, sintetizada junto à tradição com Machado de Assis, ao final daquele século. Em resumo, portanto, em 1959 Candido vê a malandragem como um objeto único, maciço e consubstancial à vida fluminense que lhe inspirou.

Esta visão do objeto brasileiro sofre uma mudança radical em 1970. Se antes a malandragem era um dado submisso ao documento, ela emerge no estudo posterior como objeto principal de análise. Esta é uma mudança notável, sobretudo se tem-se em mente o rebaixamento que Candido submete à noção de documento:

Quando o autor os organiza [os fatos da vida social] de modo integrado, o resultado é satisfatório e nós podemos sentir a realidade. Quando a integração é menos feliz, parece-nos ver uma justaposição mais ou menos precária de elementos não suficientemente fundidos, embora interessantes e por vezes encantadores como quadros isolados. Neste último caso é que os usos e costumes aparecem como documento, prontos para ficha dos folcloristas, curiosos e praticantes da petite histoire (CANDIDO, 2010, p.39, grifos no original).

Candido, ao distinguir claramente o papel do historiador e do crítico literário, eleva a noção de forma e, consequente, faz de seu objeto algo que envolva os dados documentais em um sentido formal. Torna-se claro que, para Candido, as Memórias funcionam porque, do ponto de vista literário, exerce uma função formal de redução de dados estruturais da realidade brasileira. A eleição da malandragem como este elemento reduzido, no entanto, é de vital importância para a noção de forma que Candido vislumbra: isto porque o crítico reconhece uma tensão entre uma função totalizante da forma - a 'organização da vida social de modo integrado' - e o caráter parcial deste elemento que, ele mesmo, rende o efeito de totalidade. A saber, Candido reconhece que aquilo que, ao mesmo tempo, é o fator mais marcante da obra de 
Manuel Antonio e que lhe oferecesse uma legibilidade do ponto de vista formal depende de uma relação de corte com dados fundamentais da produção oitocentista. Em outras palavras, o crítico reconhece que o que eleva a malandragem à função mediadora é precisamente uma relação de negação dos dois polos estruturais do escravismo: a relação senhores e escravos.

Ao se cortarem as duas pontas da produção, o que resta é a formalização do extrato médio da sociedade, isto é, dos homens livres e pobres que, na aparência, vivem à margem do que realmente interessa à representação daquela sociedade, dado que não exercem nenhuma função produtiva direta, vivendo de favores, bicos e trambiques. A virada da crítica candidiana se dá, todavia, precisamente neste ponto: ao perceber o caráter parcial do documento e a redução da malandragem como elemento totalizador da forma, Candido no fundo afirma que este extrato médio apenas aparenta não participar da estrutura produtiva. Isto porque, ao perceber que o romance funciona não obstante seus efeitos de obscurecimento, o crítico se dá conta que o termo reduzido é fracionado em dois polos: um polo positivo, aquele que remete diretamente à vida das camadas livres e pobres, e outro polo negativo, este sim que exerce a tal função totalizante. Trata-se, como se sabe, do favor, que se expressa como malandragem vista de seu polo positivo mas que, em sendo relação de trabalho não mediada, é também a relação jurídica fundamental de exploração na relação senhor x escravo. Ou seja, a grande fatura do ensaio é esta descoberta; a saber, que a malandragem pode exercer uma mediação não-mediada e contém mesmo em seus dados positivos - a vida leve, sem compromissos - a redução de um traço que une proprietários, escravos e dependentes na sociedade oitocentista. Isto é, que ela, através de seu caráter bruxuleante, funciona como cola entre as formações produtivas em jogo: senhores, camadas médias e escravos. Candido percebe portanto que há uma 
relação entre todas elas - o que possibilita à forma seu caráter totalizante - mesmo que esta relação não seja clara ou mesmo que seja voluntariamente cortada do plano representacional do romance ${ }^{33}$.

"A volta do marido pródigo" se insere na tradição da literatura malandra brasileira obviamente pela matéria tratada. Mas acredita-se que, à luz do ensaio de Candido, é possível afirmar que a retomada da questão da malandragem na novela relaciona-se à história brasileira menos por seu aspecto documental. Ela ganha força na narrativa e reverbera na tradição sobretudo pelo papel de operador formal que exerce sobre o desejo - paradoxal, como se verá - de totalização do texto rosiano. Sendo assim, se se procura a função aglutinante que a malandragem desempenha sobre a forma, coloca-se em perspectiva os muitos aspectos que, em Lalino, poderiam ser considerados irrealistas: por exemplo, a esquiva de qualquer disciplina laboral, o livre fluxo de suas fantasias e a capacidade de se safar de qualquer constrangimento podem ter pouco valor documental, mas têm grande peso formal.

O fato de que o narrador só consegue se ater à matéria de narração através de Lalino dá pistas de como sua malandragem se fixa a funções mais profundas do texto. Mais especificamente, Lalino é o responsável por abrir caminho para o narrador, que o segue com um objetivo muito específico: circunscrever o espaço do trabalho e da política no sertão. Não à toa, o período no Rio de Janeiro é abreviado a um único ato da novela, no qual o narrador se resume a dizer que "as aventuras de Lalino Salãthiel

\footnotetext{
${ }^{33} \mathrm{O}$ ensaio de Candido, a meu ver, deve ser exaltado por esta descoberta: a saber, que é possível a redução formal de dados não iluminados pelo romance. Isto é, que a forma pode conter traços totalizantes que não necessariamente fazem parte da matéria narrada. Trata-se de uma reviravolta importante na crítica brasileira, como atentou Roberto Schwarz, sobretudo por fundar a possibilidade de produção de teoria em contextos capitalistas heterodoxos. Claro, esta proposta em si já seria responsável por um número significativo de questões colocadas à própria noção de teoria literária materialista, a saber, como literatura e sociedade interagem formalmente quando o capitalismo não segue seu caminho de desenvolvimento 'clássico'. Não só a teoria literária teve de se haver com este problema, mas toda a teoria social que nasceu dos estudos da dependência.
} 
na capital do país foram bonitas, mas só podem ser pensadas e não contadas, porque houve demasia de imoralidade" (S, p.117-118). A busca do narrador por uma moralidade na história é, à primeira vista, somente uma nota irônica sobre a própria imoralidade dos atos de Lalino em Minas - sendo a venda da mulher ao espanhol Ramiro o mais grave. O que ela revela, no entanto, pode ser interpretado de duas formas: por um lado, pode-se presumir que simplesmente o narrador não tem interesse pelo que aconteceu no Rio de Janeiro, pois seu objeto é outro; ou pode-se também supor que o narrador não tem acesso ao que lá houve, e sendo assim poderia somente resumir os ocorridos como anedota: diz ele, sobre as histórias de Lalino na capital que

todavia, convenientemente expurgadas, talvez mais tarde apareçam, juntamente com a história daquela rã catacega, que, trepando na laje e vendo o areal rebrilhante à soalheira, gritou - 'Eh, aguão!...' - e pulou com gosto, e, queimando as patinhas, deu outro pulo depressa para trás $(\mathrm{S}, \mathrm{p} .118)$.

Dir-se-ia que as duas hipóteses são corretas e concomitantes. O narrador tem um interesse específico que não envolve as aventuras na capital, por isso as desclassifica como causos da carochinha. Por outro lado, seria possível afirmar que o narrador não pode ir ao Rio e seguir sua personagem por estar vinculado ao contexto interiorano. Mostra-se assim como, apesar de ser um narrador livre no que diz respeito ao que quer ou não quer iluminar, ele depende de um balanço de forças que só faz sentido no sertão: ou seja, sua liberdade de ir e vir entre a matéria narrada, sua permeabilidade ao enxerto de anedotas na trama e seu desprendimento temporal são facetas de uma independência relativa. Isto é, afirma-se portanto que somente em aparência há um interesse na personagem de Lalino quando, no fundo, o que sustenta o narrador é o efeito que este promove no contexto sertanejo. 
Numa palavra, o narrador está atado à malandragem no contexto sertanejo. À malandragem, como se viu, mais como operador formal do que como tema ${ }^{34}$. Ou seja, por um lado atesta-se a debilidade do narrador - ao qual, mimetizando o ziguezague de Lalino, é permitido saltos temporais e inserção de gracejos e anedotas quando a personagem some de cena ${ }^{35}$. Por outro, confirma-se a consistência de seu interesse pela malandragem em um contexto muito específico - e daí a sua força que passa a se justificar quando a novela segue em sua segunda metade.

A transição se dá maneira emblemática. Seu Oscar, filho do chefe político do distrito, Major Anacleto, encontra Lalino após seu retorno ao arraial e lhe pergunta como planeja reaver a mulher, Maria Rita, que havia cedido ao espanhol Ramiro em troca de dinheiro. O plano de Lalino, no fundo, é a ausência de um plano. Seu Oscar pergunta: "Então... Mas, tu não vai cobrar teu direito do espanhol? Vai deixar a sá Ritinha com o Ramiro?” (S, p.125). A que Lalino responde que sim, quer a mulher de volta, mas que está esperando a hora certa para agir: “se eu for agora lá, derrubo cinza

\footnotetext{
${ }^{34}$ Se o interesse do narrador fosse meramente picaresco, não haveria motivo para não seguir sua personagem nas aventuras na capital, por exemplo.

${ }^{35}$ Talvez o melhor exemplo da submissão do narrador à ordem malandra da narrativa seja a inserção, meio arbitrária, de uma versão da anedota infantil da tartaruga que quer participar da festa no céu. Sua versão 'clássica' dá conta do porquê do casco da tartaruga parecer remendado (a tartaruga, depois de descoberta, é expulsa da festa, cai no chão e tem o casco estilhaçado). A esta versão o narrador insere a figura do sapo, uma clara alegorização de Lalino, que por meio de sua lábia consegue enganar São Pedro e fá-lo jogar na água ao invés da terra. A anedota é interesse não só por seu conteúdo, já que demonstra alegoricamente as relações de malandragem agindo sobre a autoridade. O pastiche da anedota também lança uma suspeita quanto à relação do narrador com a 'seriedade' da matéria narrada. Este ponto se tornará mais claro ao final do capítulo, mas por ora poder-se-ia dizer que a aliança entre malandragem e narrador denota, por um lado, a sapiência do narrador quanto ao real assunto da novela (que por natureza deve também submetê-lo de modo a ratificar seu compromisso para com ele), por outro sua debilidade; a saber, a ideia de que se o narrador pusesse-se em uma posição de autoridade e seriedade, ele mesmo estaria falseando seus propósitos.
} 
no mingau! A Ritinha, uma hora destas, há-de estar me esconjurando, querendo me ver atrás de morro... E a espanholada, prevenida, deve de estar arreliada e armada, me esperando.” (Idem, Ibidem). Seu plano, no entanto, quanto a Ritinha é 'chamá-la no pio'. No que diz respeito ao espanhol, fazê-lo 'desencostar e cair'. Seu Oscar lhe diz: “- Mas de que jeito, seu Laio?/ - Sei não./ - E você fica aí, de papo p'ra riba?/ Esperando sem pensar em nada, p'ra ver se alguma idéia vem...” (Idem, Ibidem).

Seu Oscar interpela Lalino de modo a apontar a relação que o narrador procura no nexo entre malandragem e totalidade: “É o que é, seu Oscar. Viver de graça é mais barato... É o que dá mais... / - E os outros, seu Laio? A sociedade tem sua regra... (Idem, Ibidem, grifo meu). Novamente o quadro que se apresenta é o de contraste entre labilidade e disciplina: neste caso, uma mínima disciplina mental que seu Oscar espera de Lalino para cumprir com as poucas obrigações morais que o possibilitem a vida em sociedade. A isto Laio responde que não tem nada com estas regras e que, tivesse ele criado o mundo, o faria de acordo com seu desejo: "Magina só: eu agora estava com vontade de cigarrar... Sem aluir daqui, sem nem abrir os olhos direito, eu esticava o braço, acendia o meu cigarrinho lá no sol... e depois ainda virava o sol de trás p'ra diante, p'ra fazer de-noite e a gente poder dormir" (S, p.126).

A imagem de um mundo que dobra até o movimento do sol à sua vontade mostrará ser bastante emblemática: da mesma forma como suas fantasias revelavam um mundo do trabalho invertido, aqui ela mostra a captura do esqueleto do desejo patriarcal, já esvaziado de toda substância. Por ora, este é um dado menor, mas que, como todas as fantasias de Lalino, aponta o solo onde sua malandragem atuará. Neste quadro, uma pergunta se mostra imperativa: por que motivo o pensamento atípico de Laio, sua subjetividade solta e irresponsável, torna-se um atrativo para seu Oscar, que sugere o uso do malandro nos esquemas eleitorais do pai? 
A resposta abarca a compreensão de toda a segunda metade da novela, na qual Lalino é inserido no esquema eleitoral do Major Anacleto e, narrativamente, observase uma guinada de tom e modos de escansão da trama. Se a primeira metade serviu à apresentação do teor da malandragem de Lalino e revelou sua relação com o débil assalariamento interiorano, a segunda metade formará uma nova perspectiva sobre a mesma malandragem, desta vez vista a partir do sistema coronelista. O que 'prende' portanto o narrador ao contexto sertanejo não é tanto a personagem de Lalino, mas propriamente o nexo entre estas duas metades, o que impede que "A volta do marido pródigo" seja vista apenas como uma peça pícara, bem como as Memórias não o são para Candido.

Também aqui a malandragem derivará sua força de um constante embate referencial; se antes esta referência era a abstração disciplinar do trabalho, neste ponto ela será a autoridade do Major. O que se vê, a partir do momento em que o fazendeiro admite Lalino em seu esquema de angariamento de votos, é o constante choque entre os planos do Major e as atitudes errantes de Laio. Este, por exemplo, demora um dia para dar as caras no novo 'trabalho', o que, aos olhos do Major, já constitui uma audácia inexplicável para alguém de sua estirpe:

E, quando o mulatinho subiu, lépido, a escadinha da varanda, Major Anacleto, esquecido da condição ditada em hora severa, dispensou o intermédio de seu Oscar, e chofrou o rapaz:/ - Fora! Se não quer tomar vergonha e preceito, pode ir sumindo d'aqui! O senhor está principiando bem, hein?! Está pensando que é senador ou bispo, para ter seu estado? (S, p.129, primeiro grifo no original, segundo grifo meu)

Lalino então responde: 
Seu Major, faz favor me desculpe! Demorei a vir, mas foi por causa que não queria chegar aqui com as mãos somenos.... Mas, agora, tenho muita coisa p'ra lhe avisar, que o senhor ainda não sabe... Olhe aqui: todo-o-mundo no Papagaio vai trair o senhor, no dia da eleição. Seu Benigno andou por lá embromando o povo, convidando o Ananias p'ra ser compadre dele, e o diabo!... Na Boa Vista, também, a coisa está ruim: quem manda mais lá é o Cesário, e ele está de palavras dadas com os 'marimbondos'. Lá na beira do Pará, seu Benigno está atiçando uma briga do seu Antenor com seu Martinho, por causa das divisas das fazendas... Todos os dois, mesmo sendo primos do senhor, como são, o senhor vai deixar eu dizer que eles são uns safados, que estão virando a casaca p'ro lado de seu Benigno, porque ele é quem entende mais de demandas aqui, e promete ajudar a um, p'ra depois ir prometer a mesma coisa ao outro... (S, p.130, grifo meu).

Vê-se que a contraposição das duas falas revela, por um lado, uma ideia de poder a que o Major se agarra: a noção de que é necessário algum cargo que concentre poder - senador, bispo - para que se possa dar ao luxo de escapar à disciplina senhorial. Lalino responde com sua efetiva 'produtividade', mostrando o relatório de informações eleitorais que já conseguiu reunir. Neste movimento que se repetirá durante toda a segunda metade da novela há portanto um curso que nos interessa: o Major, proprietário de terras e com ascendência política, traça planos e emite ordens que, no entanto, são submetidos à labilidade de Laio. Mais do que um testemunho da capacidade do malandro, põe-se em cheque a fragilidade deste centro de poder patriarcal: isto é, diante das notícias que Lalino traz, o Major não tem outra escolha senão absorver as informações às suas futuras decisões políticas. Em resumo, o que a malandragem demonstra, neste caso, é um deslocamento do centro decisório das mãos do fazendeiro para um outro lugar, que é o de atuação de Lalino.

Se antes o vaivém de malandro tomava lugar num espaço vazio e socialmente inócuo, isto é, como negação à dominação abstrata do trabalho assalariado, aqui ele se posta num lugar social muito específico em que ganha ressonância e função social. A 
saber, o jogo político coronelista acomoda a malandragem de Lalino, uma vez que é cosido num leva e traz em que troca de favores definem posições políticas. À sustentação deste centro de poder é fundamental, como se vê no trecho acima, que o chefe político possa garantir, junto ao Estado, alguma garantia de manutenção da mínima estabilidade na equação posse de terras = poder político/econômico.

Numa palavra, a malandragem funciona agora dentro do esquema coronelista. Trabalha-se portanto com uma ideia de coronelismo que nem sempre é a que predomina na crítica de $\operatorname{Rosa}^{36}$. Em geral, e no contexto específico da análise desta novela, visões divergentes sobre a figuração do coronelismo podem resultar em perspectivas críticas com pontos de chegada bastante distintos. A saber, ao se considerar o coronelismo um atestado do vigor do poder privado sobre a máquina pública, torcendo-a diante de seus interesses locais, gera-se um quadro representacional em que a novela de Rosa reitera esta clivagem público x privado e não reconhece seu funcionamento sistêmico. Neste quadro, torna-se difícil encontrar uma interpretação formal para a malandragem de Lalino que não seja apologética: isto é, que escape à constatação de que a malandragem é algo como um ponto de adensamento da cordialidade brasileira, um apanhado de traços positivamente encontrados no mundo social, e que consequentemente é testemunha da dificuldade de se modernizar o Brasil. Nildo Benedetti, por exemplo, em sua análise da "Volta do marido pródigo", reitera que Lalino é "um mestre em tirar proveito das situações e das forças e fraquezas alheias, dentre as quais estão a vulnerabilidade à lisonja e a cordialidade" (BENEDETTI, 2010, p.60). O modo de análise dicotômico, e até moral, se reproduz em maior escala quando o crítico afirma:

\footnotetext{
${ }^{36}$ Ver por exemplo Roncari e Benedetti, op. cit.
} 
Lalino é, portanto, um vencedor em sua terra, mas perdedor na capital, onde os hábitos, os costumes, os valores e o progresso lhe são estranhos. É claro que o local onde vive está em processo de receber o progresso por meio da estrada de rodagem em construção, porém ele não se adapta ao trabalho disciplinado exigido a homens e burrinhos no exercício de sua tarefa. Somente em sua terra e em seu estado de atraso é que ele apropriadamente desempenha seu papel. (Idem, p.64, grifos meus).

Vê-se de que modo Benedetti iguala o atraso à cordialidade e disciplina ao progresso. Diz-se tratar de uma crítica apologética pois considera a malandragem menos um dado da forma e mais um retrato da inadequação ou resistência do sertão atrasado ante o progresso. Da mesma maneira, um sinal positivo é atribuído ao trabalho assalariado e outro negativo ao coronelismo. Disto decorre que este último é menos visto como um arranjo político original e mais como um corpo estranho, em certa medida ahistórico e resistente às forças civilizadoras que, para Benedetti, são simbolizadas pela construção da rodovia.

No primeiro capítulo tratei dos problemas desta visão sobre o sertão e mais especificamente sobre a República Velha, enxergada como um interregno entre o Império - atraso - e industrialização - progresso. Para além dos problemas políticos que correm ao fundo dessa sistematização, o principal obstáculo para a crítica é a extração de qualquer especificidade histórica do período que compreende a instauração da república e a ascensão de Vargas. Vista somente como um período de transição, a República Velha deve sua existência à insistência do atraso, por um lado, e, paradoxalmente, à projeção do futuro, do outro. Este aporte específico acaba por contaminar a análise formal, já que o enfoque no ciclo da Primeira República como devedor de substância histórica gera uma clivagem na forma, de modo que esta seja encarada ou como contraditória (avançada em sua forma, atrasada em matéria) ou 
meramente como reprodução fotográfica de uma oposição que, como no caso atraso $\mathrm{x}$ progresso, nem se eleva ao nível de contradição e dificilmente se sustenta enquanto interpretação histórica do período.

Como se tentou mostrar, obviamente a malandragem de Lalino empresta traços do que, de forma bastante ampla, se poderia chamar de 'cordialidade brasileira'. Porém, muito mais importante do que isto é a percepção de que a malandragem é menos uma alegoria e mais uma função formal. E neste sentido retira suas forças menos de uma fotografia de um vazio histórico e mais de um processo histórico real, sendo-lhe possível, como foi a Candido, que dele se extraia um senso de totalidade que permeia a forma. Assim, ao virar-se a chave de interpretação do coronelismo - de mera resistência do atraso ao progresso a um sistema político com atributos próprios - é possível uma nova visão da forma rosiana.

Uma visão unificadora do sistema coronelista já estava na mira do estudo clássico de Victor Nunes Leal, Coronelismo, enxada e voto. Logo em sua introdução, o autor defende a tese de que o coronelismo

não é, pois, mera sobrevivência do poder privado, cuja hipertrofia constituiu fenômeno típico de nossa história colonial. É antes uma forma peculiar de manifestação do poder privado, ou seja, uma adaptação em virtude da qual os resíduos de nosso antigo e exorbitante poder privado tem conseguido coexistir com um regime político de extensa base representativa (NUNES LEAL, 2012, p.4344 , grifos meus).

O estudo de Nunes Leal urde um quadro detalhado da rede de dependências a que se ligam fazendeiros, Estado e dependentes pobres. Trata-se sem dúvida de uma triangulação de bases precárias e cujos polos exibem forças desiguais, mas que coloca como centro destas relações políticas a figura do coronel. Vistos de perto, os mandos 
e desmandos dessa classe de fazendeiros podem parecer demonstração de força política; mas Nunes Leal é muito claro ao afirmar que a disputa de votos coronelista aponta, mais do que tudo, em direção a um vínculo de dependência econômica dos favores estatais que, como consequência, coloca o coronel no centro de articulação política na relação horizontal fazendeiros $\mathrm{x}$ fazendeiros, e vertical fazendeiros $\mathrm{x}$ Estado: sobre o sistema de reciprocidade na base do coronelismo afirma-se que

de um lado, os chefes municipais e os 'coronéis', que conduzem magotes de eleitores como quem toca tropa de burros; de outro lado, a situação política dominante no Estado, que dispõe do erário, dos empregos, dos favores e da força policial, que possui, em suma, o cofre das graças e o poder da desgraça (NUNES LEAL, 2012, p.63).

Mais do que a simples proposição que afirma a decadência do poder privado e a ascensão do poder estatal, é preferível enxergar estas relações à luz das transformações na estrutura produtiva do país. Como mostrado no primeiro capítulo da tese, a ascensão do café ao nível de commodity de circulação mundial tem papel fundamental nesta nova função do Estado na República Velha: trata-se de um Estado que serve aos propósitos desta fração da burguesia agrária tanto internacionalmente, mediando as relações de crédito e regulando câmbio, quanto no âmbito interno, que mais nos interessa. O Estado passa a assumir funções propriamente capitalistas quando media as relações de produção intra-setoriais, retirando do poder privado algumas atribuições que sobre ele recaíam no período colonial, como a construção de vias de escoamento de mercadorias (leia-se produtos e pessoas, como no caso das rodovias), funções policiais, jurídicas, burocráticas etc. Neste sentido, mais do que uma ascensão do Estado, tem-se uma mudança, ainda que tímida neste momento, de suas relações com a produção. 
Do lado dos coronéis, estes ficam premidos entre os setores da burguesia agrária que realmente têm acesso aos primeiros escalões da política - a saber, as elites dirigentes do país, que mesmo que não façam parte da cultura cafeeira dela dependem - e seus dependentes diretos. Este 'meio', espaço entre o Estado e a produção de mercadorias secundárias, voltadas ao mercado interno, para os coronéis é tudo; a saber, deste meio depende sua possibilidade de sustentação econômica. A briga de foice que se dá no nível local é, neste sentido, uma briga pela sobrevivência e que, vista ao longo das décadas da Primeira República, denotam processo importante de transformação. Acerca disso, Nunes Leal afirma:

Há, é certo, muitos fazendeiros abastados e prósperos, mas o comum, nos dias de hoje, é o fazendeiro apenas 'remediado': gente que tem propriedades e negócios, mas não possui disponibilidades financeiras; que tem o gado sob penhor ou a terra hipotecada; que regateia taxas e impostos, pleiteando condescendência fiscal; que corteja os bancos e demais credores, para poder prosseguir em suas atividades lucrativas (NUNES LEAL, 2012, p.46).

Vê-se, deste ângulo, de que modo o leva e traz visto na novela de Rosa, a política feita à boca miúda por Lalino, é no fundo um espelho do enredamento do produtor médio na ciranda capitalista, na qual, neste estágio, a posse do controle político de uma região significa acesso à produção para o mercado (daí a grande diferença da produção colonial) sob a forma de acesso a 'favores' do Estado, sobretudo no que tange a crédito.

Algo que pode ficar obscurecido por este véu contábil a que se dá o nome de 'as relações de crédito' é a mudança da relação do produtor com a terra e a força de trabalho, que também sofre uma rotação diante deste novo panorama capitalista. Nunes Leal nota algo que pode ser considerado uma contradição diante do quadro que 
ele mesmo esboçou a respeito da fragilidade econômica das fazendas periféricas: não obstante um aumento no número de pequenas propriedades, "a expressão percentual da concentração da propriedade rural não tem diminuído” (Idem, p.49). Há algo como um imperativo econômico que sustenta a necessidade de expansão territorial das fazendas a despeito de sua fragilidade: ou melhor, precisamente por sua debilidade, acentua-se a tendência colonial de concentração fundiária. Mas há algo que vincula o coronelismo a este quadro aparentemente paradoxal; a saber, se a disputa de poder se dá horizontalmente, entre coronéis, é de se esperar que a luta por terras tenha importância. Para além disto, no entanto, pode-se dizer que este equilíbrio instável entre crédito escasso e expansão territorial configura uma nova relação entre terra, produção e lucro.

Neste sentido aponta Francisco de Oliveira quando comenta o 'problema agrário' nos anos de transição da economia agrário-exportadora para a urbanoindustrial. Este vaivém coronelista, que mistura briga por terras, disputa política e luta por crédito, diz Oliveira, configura

um complexo de soluções cujas vertentes se apóiam no enorme contingente de mão-de-obra, na oferta elástica de terras e na viabilização do encontro desses dois fatores pela ação do Estado construindo a infra-estrutura [...]. Ela é um complexo de soluções cujo denominador comum reside na permanente expansão horizontal da ocupação com baixíssimos coeficientes de capitalização e até sem nenhuma capitalização prévia: numa palavra, opera como uma sorte de 'acumulação primitiva' (OLIVEIRA, 2003, p.43).

O uso do conceito marxiano, a acumulação primitiva, pode provocar estranheza quando aplicado ao contexto brasileiro pois, sabe-se, Marx usou-o n'O Capital para situar historicamente o processo de expropriação do campesinato como condição para 
a acumulação capitalista na Europa. Sua utilização para descrever um contexto que muito pouco lembra a situação europeia pré-capitalista acaba reclamando algum tipo de mediação por parte do teórico. Esta mediação todavia existe, e ela é o que nos interessa: em grande parte similar ao esforço contemporâneo de Roberto Schwarz de definir um arcabouço conceitual que descreva a situação periférica do capitalismo brasileiro, a acumulação primitiva de Oliveira gera uma tensão interessante na própria ideia de industrialização que, no Brasil, seguiu caminhos heterodoxos, mas não obstante reuniu os elementos básicos para sua possibilidade.

A noção de acumulação primitiva, neste sentido, serve como alternador desta possibilidade conjugada a uma impossibilidade, que tenta extrair daí as características da integração industrial do país. Oliveira diz o caso brasileiro: "trata-se de um processo em que não se expropria a propriedade [...] mas se expropria o excedente que se forma pela posse transitória da terra" (Idem, Ibidem, grifos no original). Ou seja, no coração desta relação de expansão horizontal da produção está a relação entre fazendeiros, meeiros e sitiantes, o morador que "ocupa a terra, desmata, destoca, e cultiva as lavouras temporárias chamadas de 'subsistência'; neste processo, ele prepara a terra para as lavouras permanentes ou para a formação de pastagens, que não são dele, mas do proprietário" (Idem, Ibidem).

Estas anotações são de fundamental importância para a caracterização da Primeira República como um período cujas especificidades, muito embora apontem para uma transição da base agrária à industrial, remetem a estruturas próprias que condicionam o processo de industrialização por vir. Vê-se assim que o processo de concentração de terras na Primeira República é um fator de resistência da antiga equação colonial terra $=$ poder . Mas, neste caso, o poder a que se acede com a posse fundiária é o poder sobre a valorização das mercadorias com circulação no mercado 
interno, processo que depende, como vimos acima, não só do acesso ao crédito e às benesses do Estado, mas que envolve uma profunda reestruturação da organização da mão-de-obra. É neste ponto, portanto, que Oliveira encontra Marx no questionamento: como a indústria foi possível?

A ciranda coronelista, nota-se, não é apenas um diálogo entre iguais: ela depende, em última instância, da relação que estabelece com os dependentes da propriedade rural, que passam de uma situação de relativa estabilidade quando a produção na fazenda vinculava seus trabalhadores à terra - a crueza da mão-de-obra a outra de constante agitação quando estes mesmos dependentes passam a servir de ponta de lança do processo de acumulação primitiva no interior do Brasil. Referi-me a esta segunda situação como 'desenraizamento' dos dependentes pobres, situação que, agora, mostra-se não apenas uma consequência da concentração de terras, mas uma necessidade para a sustentação do próprio sistema coronelista. Como afirma Oliveira, há neste processo de constante arregimentação precária de mão-de-obra que trabalha na terra uma "transferência de 'trabalho morto', de acumulação, para o valor das culturas ou atividades do proprietário" (OLIVEIRA, 2003, p.43).

A noção de 'trabalho morto' volta a aparecer como significante importante para a discussão sobre a possibilidade da indústria no Brasil. Sabe-se, pela construção teórica de Marx n'O Capital que, grosso modo, trabalho morto é a quantidade de trabalho transferida de uma etapa da produção para outra. Apesar de sua aparente simplicidade, a proposição pressupõe a complicada discussão sobre o que é 'trabalho abstrato', a saber, o termo que, em toda mercadoria, é comunicável a outra, sendo portanto uma redução abstrata de qualquer trabalho, não importando seus fins ou especificidades, que comunica o valor. Marx, nos primeiros capítulos do livro, deixa claro que se trata de um traço que caracteriza o capitalismo e, portanto, é mesmo a 
base da definição do valor como esta malha de comunicabilidade de trabalhos num sistema de troca de mercadorias. Sobre a questão específica do trabalho morto, afirma Marx, usando o famoso exemplo da produção de algodão:

O tempo de trabalho requerido para a produção de algodão, que é a matéria-prima do fio, é parte do tempo de trabalho requerido para a produção do fio, e, por isso, está contido neste último. [...] Assim, quando se considera o valor do fio, ou o tempo de trabalho requerido para sua produção, todos os diferentes processos particulares de trabalho, que, separados no tempo e no espaço, têm de ser realizados para, primeiramente, produzir o próprio algodão e a quantidade de fusos necessária à fiação e, posteriormente, para obter o fio a partir do algodão e dos fusos, podem ser considerados fases diferentes e sucessivas de um mesmo processo de trabalho. Todo o trabalho contido no fio é trabalho passado (MARX, 2013, p.264-265, grifo meu).

Marx claramente promove a ideia de que o valor se constitui a partir da abstração de trabalhos passados, função da acumulação que é possível no capitalismo porque estes trabalhos se comunicam através de sua redução a trabalho abstrato. O trabalho morto, nesse sentido, contido no algodão, é portanto reavivado pelo trabalho de tecelagem, cujo fim é em parte a transferência do valor de uma forma da mercadoria para outra.

No caso da acumulação primitiva, como conceituada por Marx, ou mesmo no caso brasileiro, vislumbrado por Oliveira, o processo é um pouco mais complexo. Trata-se em suma de uma situação em que esta comunicabilidade do valor é impossível, pois o mercado de mercadorias é incipiente; isto é, a redução do trabalho específico a trabalho abstrato é barrada pela impossibilidade de redução das horas de trabalho em salário, que pode comprar outras mercadorias e assim comunicar à 
produção qual é o trabalho 'socialmente necessário' para sua concretização ${ }^{37}$. Neste caso, portanto, em que, numa palavra, o dinheiro ainda não exerce o seu papel como portador de valor, o processo de acumulação primitiva se dá sempre numa relação direta entre a formação dos meios de subsistência pelo trabalhador e o trabalho que gera lucro ao proprietário: como os meios de subsistência não conseguem se expressar em salário, a única maneira de fazer com que o trabalho passado se comunique com o presente é através da formação de novas fronteiras agrícolas, pois com isto um novo ciclo de relação entre subsistência e trabalho produtivo se inicia. Trocando em miúdos, a acumulação primitiva se dá horizontalmente porque ela precisa constantemente renovar o nexo entre trabalho dispendido e trabalho necessário, já que uma rede de comunicabilidade do valor é inexistente.

Em termos mais concretos, ao trabalhador rural brasileiro era impossível transferir o trabalho morto ao capitalista sem reiniciar o ciclo de produção, no qual ele mesmo trata de criar um bolsão de subsistência que o sustente, e formar as bases da cultura por vir, através do desmatamento e preparação mínima da terra. Uma vez iniciado este processo, o trabalhador é dispensado ou levado a novas fronteiras, onde o ciclo se reinicia. Daí o sentido do 'desenraizamento' a que se referiu anteriormente que, como se vê, está estruturalmente ligado à dinâmica capitalista da Primeira República.

\footnotetext{
${ }^{37}$ Neste ponto, na teoria de Marx, fica claro que a relação salário/dinheiro não é simplesmente contábil ou responde somente às relações de oferta e demanda. A noção de 'trabalho socialmente necessário' é aqui peça fundamental para este entendimento: a saber, o trabalho só consegue comunicar sua necessidade a partir do momento em que a rede de comunicação de valor, que possibilita a metamorfose de dinheiro em mercadoria, se estabelece. O mesmo adágio poderia ser dito de outra forma: a necessidade somente se dá via relação entre trabalho e capital, mesmo que esta relação tenha que, num primeiro momento, ser imposta. Neste ponto, salário e meios de subsistência indicam o seu nexo primordial na teoria marxiana, sobretudo quando se tem em mente a menção de Marx ao trabalho abstrato como sendo, em última instância, o trabalho 'muscular' a que todo tipo de trabalho deve ser reduzido no capitalismo.
} 
Diante desta perspectiva sobre o coronelismo percebe-se como não há, de fato, como parte da crítica de Rosa acredita, um abismo entre o arcaico e o moderno, ou mesmo uma oposição simples entre eles. No caso específico da novela "A volta do marido pródigo", ao contrário do acredita Nildo Benedetti, a malandragem não se constitui como retrato positivo da cordialidade que atravanca o progresso. Ela é, antes, a formalização desta negatividade que habita o processo de desenraizamento do trabalhador rural e que, surpreendentemente, é a própria condição para a formação capitalista das relações no campo: a labilidade revela de que forma o favor acopla-se às necessidades de expansão de terras, residindo portanto numa zona cinza em que a impossibilidade de assalariamento é o que, ao mesmo tempo, liga o coronelismo a um processo capitalista e lhe empresta traços tão heterodoxos. Assim, pode-se afirmar que as ações de Lalino habitam precisamente este espaço de impossibilidade de comunicação do valor, seja no bolsão de assalariamento, no qual a disciplina laboral não tem efeito porque não consegue se erigir como necessidade; seja em sua atuação na política coronelista, em que atua no vão entre o proprietários, seus pares e o Estado, com vistas à expansão horizontal da acumulação, i.e. à acumulação primitiva.

Esta perspectiva explica também a própria caracterização de Major Anacleto como um proprietário cuja autoridade se sustenta por um fio e cuja articulação política acontece como que às suas costas. Isto é, há sempre algo a ser feito, algo a ser urdido, de modo que o Major está sempre correndo atrás das consequências das atitudes de Lalino, que lhe vai abrindo espaço em meio à costura eleitoral:

Com o relatório de Lalino, o Major compreendeu que não podia ficar descansado. Tinha de virar andejo. Mandou selar a mula e bateu para a casa do Vigário. Mas, antes da sua pessoa, enviou uma leitoa. Confessou-se, deu dinheiro para os santos. O padre era amigo seu e do Governo, mas, com o raio do Benigno chaleirando e intrigando, a 
gente não podia ter certeza. Felizmente, estava vago o lugar de inspetor escolar. Ofereceu-o ao Vigário. (S, p.132, grifo meu).

Vê-se que o proprietário está sempre um passo atrás do processo, tecendo-o com o que tem em mãos a oferecer - neste caso, um cargo de inspetor escolar. O narrador, que seguira de perto as ações de Lalino na primeira metade da novela, agora faz o mesmo, mas desta vez recebendo notícias de 'segunda mão': isto é, segue o Major que segue Laio. Não é fortuito portanto o uso do pronome 'a gente' no excerto acima: o narrador toma partido, não só porque se identifica com Lalino e posteriormente com Major Anacleto, mas sobretudo porque só consegue ver através deste rastro. A narrativa percorre então este ziguezague provocado por Laio, um diz-que-não-diz que configura a todo momento o embate entre a autoridade corrompida do Major e as ações de Lalino, acompanhadas a todo momento por uma sombra de dúvida quanto a sua lealdade. Quando o Major, por exemplo, descobre que Lalino anda visitando a Boa Vista, foco da oposição, ao lado do filho do adversário, o proprietário se enfurece: “- Então, seu caradura, seu cachorro! O senhor anda agora de braço dado com o Nico do Benigno, de bem, para me trair, hein?!... Mal-agradecido, miserável!... Tu vendeu a mulher, é capaz de vender até as hóstias de Deus, seu filho de uma!” (S, p.134).

Apesar do aspecto cômico da situação, ela diz muito sobre a reestruturação da noção de lealdade e, consequentemente, de dependência que se estabelece no contexto coronelista. Numa palavra, se no contexto rural neocolonial ${ }^{38}$ o agregado era parte integrante da fazenda, que funcionava como um centro de irradiação quase inconteste

\footnotetext{
${ }^{38}$ Usamos aqui a terminologia de Florestan Fernandes em A revolução burguesa no Brasil para caracterizar o período que, politicamente, compreende o intervalo entre a independência e a república.
} 
de poder, a noção de lealdade se distribuía em círculos concêntricos a partir do proprietário. A traição, portanto, era tão mais grave quanto mais próximo deste centro o dependente estivesse: o caminho inverso era também possível, o agregado podia avançar em direção ao centro se demonstrasse grande lealdade (basta pensar novamente n'O sertanejo de Alencar, em que o vaqueiro Arnaldo, após inúmeras demonstrações de fidelidade, é convidado a integrar a família proprietária). Este centro fixo de poder facilita a perspectiva narrativa, já que o mundo da fazenda é praticamente um mundo fechado em si no que diz respeito a suas relações de produção e jurídicas ${ }^{39}$, possibilitando que a narrativa se expanda até os limites da propriedade se adotar a perspectiva senhorial.

Este decerto não é o caso de "A volta do marido pródigo". Embora, em sua segunda metade, o narrador assuma a perspectiva patriarcal, ela não the garante um ponto de perspectiva fixo. A incerteza é portanto tanto da personagem como do narrador: é verdade que a novela ganha processualidade com sua segunda metade, precisamente porque a perspectiva do narrador é expandida com a entrada de Lalino na política. Mas ainda assim é correto afirmar que sua visão é limitada no sentido de que o sujeito da narração - a instância narrativa que lhe confere um senso de totalidade - não pertence ao narrador, é em verdade por ele perseguido. Neste sentido é correto afirmar que um traço que distingue a situação neocolonial à coronelista é que o proprietário periférico não habita mais um centro fixo que identifica posse de terras a poder econômico e jurídico. O proprietário coronelista, assim como seus dependentes, postam-se num centro semovente, no qual a propriedade ainda tem papel fundamental na garantia de uma estabilidade frágil de poder. Mas a noção de

\footnotetext{
${ }^{39}$ Fala-se em relações jurídicas porque elas se expressam, no contexto neocolonial, na própria pessoa do proprietário. Isto é, dele deriva a lei e, consequentemente, o julgamento sobre traições.
} 
propriedade privada muda: ela se torna meios de produção no sentido capitalista, isto é, apenas o suporte da produção e portanto de atravessamento do valor, o nó onde se dá o processo de valorização que deve se reiniciar a cada ciclo produtivo, com o avivamento do trabalho morto e produção de mais-valor.

Os traços nada ortodoxos do capitalismo brasileiro dificultam a visão do coronelismo nesta chave. Neste sentido, a narrativa rosiana, ao acompanhar de perto e percorrer todas as dobras do sistema político em questão, tem grande papel na documentação das características deste quadro. Mas, para além disso, a maneira como ela se posiciona é fundamental para a defesa da tese de que seu objeto final é a captura formal deste processo. "A volta do marido pródigo" é um texto que se inicia com uma perspectiva limitada e paulatinamente amplia seu escopo. A passagem do tempo, como se viu, é primeiramente organizada em pequenos atos que encerram cenas muito específicas em cujo centro está a ação malandra de Lalino. Neste sentido, o tempo na primeira metade da novela é medido como função da impossibilidade de assalariamento: ou seja, a temporalidade atesta a existência de miniciclos de trabalho que, incapazes de se perdurar como comunicação de valor, fecham-se sobre si. A partir do momento em que o narrador se posta sobre os ombros do Major, a noção de temporalidade muda: ainda se está colado às perturbações que Laio promove no interior do sistema sertanejo, mas desta vez ela se põe à luz de um ciclo maior, que é o da política. Melhor dizendo: na segunda metade acompanha-se o tempo de um ziguezague no interior do ciclo eleitoral, até que ele se feche.

O final da novela é exemplar neste sentido. Mais uma vez suspeita-se de traição de Lalino, que teria sido visto conversando com deputados da oposição. Enquanto isso, o Major recebe Maria Rita, que pede que o proprietário interceda na relação entre ela, o espanhol e Laio, o que o coloca em situação difícil pois é amigo 
dos espanhóis. A posição do fazendeiro oscila em favor e contra Lalino de acordo com as notícias que recebe, isto é, seu poder de decisão está nas mãos do malandro, que, traindo ou sendo fiel à aliança, pode minar ou selar sua permanência como principal cabo político na região.

Este momento é emblemático sobretudo porque faz apontar diversos vetores narrativos em direção ao fazendeiro, inclusive todo o imbróglio envolvendo Lalino e sua mulher. Enquanto o narrador observa este movimento, a real ação se dá às suas costas, sob o signo da incerteza, quando Lalino age a favor ou contra o Major. Tem-se então um quantum narrativo que aponta para o centro patriarcal, mas ele é oscilante e no limite vazio, pois seu poder decisório está nas mãos de uma ação outra, que acontece no escuro, para além da perspectiva narrativa. Por este motivo o Major oscila e no limite é incapaz de decidir:

- Calma, criatura! - levanta, vai lavar esses olhos... Ó Vitalina, engambela ela, dá um chá à coitadinha... Afinal... afinal ela não tem culpa de nada... É uma história feia, mas... Nem o Eulálio não tem culpa também, não... Foi só falta de juízo dele, porque no fundo ele é bom... Mas, que diabo! O espanhol é boa pessoa... Arre! (S, p.145).

As reticências que povoam a fala do Major são o signo dos deslizamentos no pensamento do proprietário: o que eles indicam é sobretudo a incapacidade de ligar um veredito à pessoa de Lalino, Maria Rita e o espanhol. Este veredito, como se disse, depende de uma outra ação, do tipo de costura política que Eulálio empreende às suas costas. Vê-se portanto em que medida o arranjo jurídico cordial está comprometido: embora haja o desejo por parte do Major de sustentá-lo, ele escapa às suas mãos porque o centro decisório que vincula propriedade e poder se desloca para um lugar outro que não a figura do proprietário. 
Quando se descobre o que houve neste espaço escuro - a saber, que Lalino garantira uma visita do secretário do interior, membro do governo, à fazenda, onde o Major pôde oferecer toda hospitalidade - todos os mesmos vetores que apontavam para o centro patriarcal oscilante voltam a fazê-lo, agora com o poder de volta às mãos do Major:

Major Anacleto chama Lalino, e as mulheres trazem Maria Rita, para as pazes. O chefão agora é quem se ri, porque a mulherzinha chora de alegria e Lalino perdeu o jeito. Mas, alumiado por inspiração repentina, o Major vem para a varanda, convocando os bate-paus:/ Estêvam! Clodino! Zuza! Raymundo! Olhem: amanhã cedo vocês vão lá nos espanhóis, e mandem aqueles tomarem rumo! É para sumirem, já, daqui!... Pago a eles o valor do sítio. Mando levar o cobre. Mas é para irem p'ra longe!/ E os bate-paus abandonam o foguinho do pátio, e, contentíssimos, porque de há muito tempo têm estado inativos, fazem coro (S, p.149, grifos meus).

Neste momento finalmente as reticências abandonam a fala do Major e chega ao fim o movimento de ziguezague, ensejando assim um fecho à narrativa:

No alto, com broto de brilhos e asterismos tremidos, o jogo de destinos esteve completo. Então, o Major voltou a aparecer na varanda, seguro e satisfeito, como quem cresce e acontece, colaborando, sem o saber, com a direção-escondida-de-todas-ascoisas-que-devem-depressa-acontecer. (S, p.150, grifos meus).

Com a bênção das estrelas e do coro de sapos, "em festa [...] a exultar" (Idem, Ibidem), a novela chega ao fim com alta voltagem irônica. Tem-se um cenário narrativo inusitado, pois com a retomada das rédeas políticas pelo Major e o fim do jogo coronelista, o narrador parece satisfeito com o material alcançado: isto é, tem-se enfim uma história digna de se contar. Porém, ao fazê-lo, o narrador se coloca à 
disposição do próprio material que narrou e se coloca no mesmo nível das personagens, que se dão por satisfeitas com a precária estabilização das amarras políticas a que se chega. Para ser mais exato, o narrador continua na mesma posição que sempre ocupou, que é a de terceira voz neste jogo de vaivém, apenas um observador que ansiava também pelo final do ciclo político. A verdadeira matéria da ação, no entanto, mostra-se a despeito da autoridade do narrador e precisamente através de sua ironia: neste fecho que não fecha, com um 'destino' que se assegura até o início de uma nova rodada de negociação política, o verdadeiro sujeito da narrativa mostra que habitou o lugar da sombra da malandragem o tempo todo.

Em outras palavras, este sujeito mostra-se ao final em seu refluxo sobre o proprietário, investindo-lhe de poder temporário, e desta forma afirma sua presença durante toda a narrativa como parte que habitava negativamente as ações de Lalino. Mais claramente, Lalino, sobretudo na segunda metade da novela, perseguia os acordos políticos que garantiriam o poder ao Major. No entanto este mesmo poder que lhe é conferido é apenas o poder para reiniciar o mesmo ciclo que lhe desinveste de poder novamente. Numa palavra, dir-se-ia que o verdadeiro sujeito da narrativa é o próprio circuito político do sertão que, no contexto sertanejo da Primeira República, persegue o próprio rabo, sem conseguir verdadeiramente transformar lucro em capital político e financeiro. Ou seja, que não consegue se valorizar. Por isso a narrativa assume este aspecto de um ziguezague dentro de um círculo: quando se toca na fronteira do círculo, a sensação é de que se vira a página e começa-se tudo de novo. Esta eterna volta ao lugar de instabilidade mimetiza portanto o próprio movimento de acumulação que descrevemos.

Importante ressaltar que ele sempre teve, desde o início da novela, que acontecer a despeito do narrador: se este realmente tivesse poder sobre a narrativa, 
estivesse em situação privilegiada para sintetizar a ação num quadro mais amplo, ele trairia o próprio movimento histórico que buscava formalizar, que é a rigor um processo encabeçado por um sujeito que funciona de acordo com a estrutura econômica da Primeira República, e por isto necessariamente contra a ação dos sujeitos econômicos, como o fazendeiro, porque é um movimento em falso. Por isso a ironia ao final tem alto valor formal: porque evidencia como o narrador se coloca à disposição deste quadro maior da política, cujo efeito de totalização deve acontecer a despeito dos sujeitos inseridos na ciranda coronelistas. Ou seja, o narrador oferece um falso fecho - o cumprimento da direção-escondida-de-todas-as-coisas-que-devemdepressa-acontecer - como isca ao atravessamento do verdadeiro movimento de sintetização da trama, que é a do ciclo acumulativo.

Chega-se assim à interessante constatação de que este efeito de totalidade que a narrativa oferece ocorre num movimento que aponta para a história, mas dá ares de não apontar, porque é circular e sem rumo. O sujeito que tece sua verossimilhança, por sua vez, é um sujeito oculto e paradoxal, pois ao mesmo tempo em que constrói a posição do narrador, sabota-a ao sugerir um equilíbrio débil e irônico.

O centro de poder que a narrativa buscou perseguir a todo custo, no momento em que se mostra, evidencia estar num para-além de sua capacidade de apreensão: quando a narrativa chega no ponto desejado, ele já não está mais lá, por isto ela se fecha quase como anedota, não obstante o rico valor realista a que acede. Trata-se de um movimento que se mostra importante na caracterização dos arranjos narrativos em Sagarana: a saber, a colocação de um narrador em situação, envolvido na trama, seja como expectador, contador de causo ou como personagem. Este posicionamento é fundamental para a ideia de síntese e de totalização a que as novelas podem atingir; isto é, elas precisam subjugar o narrador, colocá-lo como voz implicada num processo 
que ocorre a seu despeito, de modo que a redução estrutural do processo histórico mirado seja possível. Este processo histórico, já se pode dizer, deve prestar contas ao próprio ciclo acumulativo do sertão, a este centro que se move horizontalmente, sempre mantendo sua possibilidade de construção num lugar outro.

Evidencia-se aqui o nascimento de um tópico muito caro à literatura de Rosa: a ideia de sertão como centro instável, de revolução constante de certezas e parâmetros ético-políticos, desestabilizador de dicotomias etc. Não se trata de uma invenção do autor, muito embora se lhe possa atribuir os méritos de formalizar este processo histórico talvez como nenhum outro autor brasileiro. Também não é o caso de atribuir esta noção de sertão a influências eruditas que, sobretudo no Grande sertão, foram adicionadas a esta estrutura narrativa já presente em Sagarana. O que se pode dizer é que Rosa, no livro de 1946, inicia a estratégia de formalização deste processo histórico, iniciado com a nova república. Mas acede-lhe já vendo-o como objeto autônomo, mostrando em que medida deve a formalização do sertão à situação histórica pós-1930, na qual o pitoresco perde força em benefício da figuração dos nexos do sertão com os processos de integração acumulativa do país. Neste caso, uma integração que está lá; mas no momento em que se lhe mira o olhar, já está num lugar outro. 


\section{Sarapalha}

Tapera do arraial. Ali, na beira do rio Pará, deixaram largado um povoado inteiro: casas, sobradinho, capela; três vendinhas, o chalé e o cemitério; e a rua, sozinha e comprida, que agora nem mais é uma estrada, de tanto que o mato entupiu./ Ao redor, bons pastos, boa gente, terra boa para o arroz. E o lugar já esteve nos mapas, muito antes da malária chegar. (S, p.151, grifo meu).

Assim se inicia "Sarapalha", a terceira novela de Sagarana. O narrador, de chofre, joga o leitor no local exato de desenvolvimento da trama. A caracterização do espaço é um atestado de seu desolamento. A posição do narrador, no entanto, é ambígua: ele toma meia-distância do lugar de interesse, como se estivesse de passagem pelo local e a visão daqueles restos de civilização the instigasse a memória. Apoiando-se nesta estranha familiaridade, o narrador demonstra saber a cadeia de causalidades que levou o vilarejo a esta situação:

Ela veio de longe, do São Francisco. Um dia, tomou caminho, entrou na boca aberta do Pará, e pegou a subir. Cada ano avançava um punhado de léguas, mais perto, mais perto, pertinho, fazendo medo 
no povo, porque era sezão da brava - da 'tremedeira que não desmontava' - matando muita gente. (Idem, Ibidem).

A caracterização do narrador como observador eventual - isto é, alguém que conhece a região, conhece o acontecido, mas não o viveu nem o observou de tão perto - é fortalecida por um procedimento que insere os outros - moradores da região - em sua fala. A marcação da passagem do tempo - de quando a vila era funcional e saudável, ou 'pertencia aos mapas' - para sua condição atual, é feita através de falas que, sem o prejuízo do conceito, podem ser chamadas de fantasmáticas: “ - Talvez que até aqui ela não chegue... Deus há-de... / Mas chegou; nem dilatou para vir" (Idem, Ibidem). Trata-se de falas fantasmas porque são a presentificação de uma elocução passada, de um morador desconhecido, a que o narrador teve acesso e que serve somente a um propósito: pôr em relevo o avanço de um agente impessoal, a doença, contrapondo-o à esperança dos moradores. O narrador portanto coloca-se entre duas frentes de impessoalidade: a doença e a voz dos moradores.

Novamente, a descrição do avanço da malária se usa deste procedimento:

Em abril, quando passaram as chuvas, o rio - que não tem pressa e não tem margens, porque cresce num dia mas leva mais de mês para minguar - desengordou devagarinho, deixando poços redondos num brejo de ciscos: troncos, ramos, gravetos, coivara; cardumes de mandis apodrecendo; tabaranas vestidas de ouro, encalhadas, curimatãs pastando barro na invernada; jacarés, de mudança, apressados; canoinhas ao seco, no cerrado; e bois sarapintados, nadando como búfalos, comendo o murerê-de-flor-roxa flutuante, por entre as ilhas do melosal. Então, houve gente tremendo, com os primeiros acessos da sezão:/ - Talvez para o ano que vem ela não volte, vá s'embora.../Ficou. (S, p.151-152, grifos meus). 
Neste trecho é mais claro o que intenta o narrador. Ao ciclo natural do rio, que enche e depois estia, acompanha a ação marginal de diversos restos - tocos, galhos, poças, peixes mortos etc. - que, passivamente, abrem espaço para a atividade da doença, que vem avançando com o rio. Depois, ao meio do caminho de uma circunferência que vai do centro do impessoal da doença às margens, aparecem os animais fugindo do cenário pantanoso. E, por fim, no limite deste círculo, há a ação humana, que toca o gado para fora da região e já sofre com os sinais da sezão.

Como se percebe, há um contínuo que vincula a passividade do ciclo de cheia e estiagem do rio, que passa pelos animais e chega à ação humana, deixando o lugarejo. Este círculo de ação é, no entanto, subvertido quando da chegada da doença, e novamente a fala fantasmática exerce uma função na construção desta estrutura: a frase intercalada ao processo de aproximação da malária marca um ponto de virada, no qual a lógica deste círculo é desfeita e, no limite, invertida, já que depois que a doença fica, o teor da ação muda de figura e dá lugar à impessoalidade e à disfunção: “Quem foi s'embora foram os moradores: os primeiros para o cemitério, os outros por aí a fora, por este mundo de Deus. As terras não valiam mais nada. Era pegar a trouxa e ir deixando, depressa, os ranchos, os sítios, as fazendas por fim” (S, p.152, grifo meu). Torna-se claro, assim, que a marcação temporal não serve tanto para localizar no tempo o ocorrido: ela se presta a engendrar um movimento de definhamento da ação humana e a tomada de cena de algo que chamarei de ação coisal: em termos claros, quem toma as rédeas da ação não são os homens - estes somente agem negativamente, adoecendo, morrendo, ou fugindo - mas sim a própria malária. Assim, faz sentido que uma voz fantasma sirva a este propósito, uma vez que quem fala não é ninguém: é apenas a voz servindo como passagem para a doença, que a empurra, já neste ponto, para um local muito além da ação humana e sua consequente elocução. 
Quem fala é o narrador, mas o processo que descreve é estranho, pois permeado por vozes fantasmas e pelo avanço da ação da malária.

Este, portanto, ao permitir a inversão deste núcleo de ação, passa a descrever a redução do vilarejo a resto, consumido pelo mato e povoado por animais:

\begin{abstract}
Aí a beldroga, em carreirinha indiscreta [...] apontou caules ruivos no baixo das cercas das hortas, e, talo a talo, avançou. Mas o cabeça-deboi e o capim-mulambo, já donos da rua, tangeram-na de volta; e nem pôde recuar, a coitadinha rasteira, porque no quintal os joás estavam brigando com o espinho-agulha e com o gervão em flor. [...] Os passarinhos espalhavam sementes novas. A gameleira, fazedora de ruínas, brotou com o raizame nas paredes desbarrancadas. [...] $\mathrm{E}$ aí, então, taperização consumada, quando o fedegoso em touças e a bucha em latas puderam retomar seu velhíssimo colóquio, o povoado fechou-se em seus restos, que nem coscorão cinzento de uma tribo de marimbondos estéreis. (Idem, p.152, grifos meus).
\end{abstract}

À primeira vista, este primeiro movimento da novela poderia encerrar um gesto de aproximação da matéria narrada que, em aparência, reitera a posição semi-distante do narrador, já que a este é possível observar a ‘taperização' do vilarejo com alguma objetividade: ele vê de fora tanto o processo temporal que levou à redução a resto como observa os efeitos físicos da devastação da malária. Neste sentido, o narrador poderia ser um viajante, uma pessoa que conhece e circula pela região sem necessariamente ter vínculos com o arraial; ou alguém que ouviu a história como causo, perdida no tempo e alegorizada. Mas este lugar perde força com a própria aproximação da malária como agente que devasta o arraial e gera um leito de impessoalidade por onde passa, jogando a ação para as margens deste movimento. Este processo afeta também o narrador, que, ao adentrar o leito principal da narrativa, 
abandona sua semi-distância e mergulha também no centro das ações coisais, que se configura como o centro da matéria narrada.

Toda a preparação nas primeiras páginas da novela, muito embora lembrem a estrutura do causo - isto é, remetam a um interesse contingencial por uma narrativa de conteúdo extraordinário -, serve de fato à mitigação da posição do narrador como sintetizador do narrado. Isto é, a distância posta de início, aliada à parca marcação temporal, geram um efeito de deslocamento do narrador de uma posição central - ele vê e descreve, e assim se aproxima da matéria em questão - a uma posição marginal ele simplesmente acompanha e comenta o movimento das coisas. O conteúdo narrativo de "Sarapalha" somente se mostra quando esta posição já fora alcançada, no momento em que chega no local desejado:

É aqui, perto do vau da Sarapalha: tem uma fazenda, denegrida e desmantelada; uma cerca de pedra-seca, do tempo de escravos; um rego murcho, um moinho parado; um cedro alto, na frente da casa; e, lá dentro, uma negra, já velha, que capina e cozinha o feijão. Tudo é mato, crescendo sem regra; mas, em volta da enorme morada, pés de milho levantam espigas, no chiqueiro, no curral e no eirado, como se a roça se tivesse encolhido, para ficar mais ao alcance da mão $(\mathrm{S}$, p.153, grifos meus).

A narrativa para, temporalmente, e estaciona neste lugar até seu fecho. A partir deste momento, toda a função descritiva do narrador lhe é tolhida: ele se colocará ao lado, apenas acompanhando a pulsação da malária, sua ação sobre as personagens Primo Ribeiro e Primo Argemiro. Antes de partir para o arranjo que verdadeiramente caracteriza "Sarapalha", é preciso atentar aos dados que o narrador menciona apenas de passagem. 
A novela é peculiar do ponto de vista formal, e por isso mesmo difícil de se apreender criticamente. Isto porque ela se direciona a um ponto em que toda matéria processual chega ao limite da paralisia. Ou, numa palavra, não haveria muito a se narrar sobre um vilarejo fantasma a não ser o seu próprio processo de encolhimento e morte, que é o que caracteriza a primeira seção do texto. Mas o narrador se utiliza do processo para ele mesmo alterar sua posição de modo que, ao deslizar os processos narrativos da vida humana no vilarejo para a ação coisal, a redução seja vista através da perspectiva do corte da vida normal e funcional do lugarejo. É o que se observa, por exemplo, na fazenda dos primos Ribeiro e Argemiro: a descrição muda de tom ao se falar de uma antiga fazenda na qual o mato passa a agir mais que os homens; ou que a roça, com vontade própria, se encolhe para ficar ao alcance da mão. Ao atribuirse agência aos objetos, o narrador caracteriza algo como uma antiação que, como se vê no exemplo da fazenda, é a forma de narrar uma cesura nos aspectos funcionais da produção.

"Sarapalha" apresenta então um quadro que, do ponto de vista narrativo, forma-se como uma encruzilhada: a partir da redução a resto e da atribuição da agência às coisas, o que se coloca em relevo é a negatividade da ação humana vista somente como corte. Por exemplo, do mato que, ativamente, engole a fazenda; do milho que cresce sem rumo, pode-se ver, em negativo, a ação humana na produção e cultura da fazenda. O trabalho crítico deve partir então de alguns pontos base: qual o interesse do narrador em excluir a ação humana e mostrá-la somente em negativo? Como se dá a relação entre esta negatividade e a agência das coisas? E, por fim, como estas questões se relacionam com um quadro histórico a que estes vetores de negatividade podem ser atribuídos? À configuração deste quadro dedicaremos a próxima seção deste texto. 
Mais uma vez voltamos à crítica de Nildo Benedetti como contraponto. O crítico vê o processo de negação da novela como a fotografia de um "local de retrocesso ao estado de natureza", como "repúdio dos dois homens [primos Argemiro e Ribeiro] de qualquer condição civilizada" (BENEDETTI, 2010, p.94-95). A estagnação da novela, e até mesmo sua ação final, são para o crítico sinais de conformação ao arcaico. Isto é, a um lugar social oposto à civilização. A narrativa se coloca voluntariamente neste lugar, é verdade, mas na visão de Benedetti com o claro intento de atestar a imobilidade que assola o interior do Brasil.

Como já discutimos o problema da identificação do 'arcaico' à ausência de processos sociais, não nos deteremos longamente sobre o ponto. Vale notar, como vimos acima, que mais do que uma fotografia da imobilidade, trata-se de uma imobilidade ativamente procurada e em certa medida construída por forças que atuam no interior da narrativa. Ou seja: não se encontra um estado de paralisia (menos ainda de natureza), mas sim um processo de paralisação. A percepção de que há forças que atuam neste sentido deve apontar a crítica mais na direção dos processos em si do que na imagem que eles geram. Somente assim se poderá ter uma visão da novela como forma - isto é, como malha em que processos e imagens agem juntos na geração do efeito narrativo. O direcionamento à crítica formal de "Sarapalha" deve portanto encontrar uma implicação mimética que dê conta, ao mesmo tempo, de processos de 'geração ativa do arcaico' e de paralisia social. Em outras palavras, deve-se procurar historicamente dinâmicas sociais que atuem sobre o sertanejo na promoção de seu fechamento sobre um resto produtivo. 
O enclausuramento do caipira a um vínculo precário com a terra é o objeto de estudo de Antonio Candido em Os parceiros do Rio Bonito. A própria noção de restrita mobilidade, analisada pelo crítico, é em si uma situação sem precedentes históricos e, portanto, uma criação do século XX. A configuração desta contradição histórica, na qual o sistema de parceria se vê pressionado pelas transições produtivas da primeira metade do século, é o objeto de Candido: a precariedade da produção não era novidade no sistema caipira, mas sim sua ambígua relação com a terra. $\mathrm{Na}$ sociedade sertaneja, no período colonial e neocolonial, a precariedade da produção era compensada pela alta mobilidade e possibilidade de expansão de novas fronteiras agrícolas, onde o ciclo de subsistência se repetiria e se estabilizaria no que o autor chamou de mínimos vitais. Ligado a este panorama estava um estatuto maleável de propriedade, que permitia ao caipira aventurar-se por terras desocupadas:

\begin{abstract}
A posse, mais ou menos formal, ou a ocupação pura e simples, vêm juntar-se aos tipos de exploração e ao equipamento cultural, a fim de configurar uma vida social marcada pelo isolamento, a independência, o alheamento às mudanças sociais. Vida de bandeirante atrofiado, sem miragens, concentrada em torno dos problemas de manutenção dum equilíbrio mínimo entre grupo social e meio. (CANDIDO, 2010, p.56, grifos meus).
\end{abstract}

Há algo em "Sarapalha" que joga a narrativa para esta condição de atrofiamento que remete às raízes da sociedade caipira. Mas, como se apontou, a mobilidade lhe é tolhida, de modo que a relação de agência se inverte: não é mais o caipira que se move dando, portanto, continuidade ao ciclo produtivo de subsistência. Antes, é a malária que se move e encarcera a fazenda em "Sarapalha", junto com seus proprietários. A agência da doença e a insistência da narrativa em se ater à 
imobilidade é portanto um dado fundamental do texto, que aponta para um outro tipo de precariedade social, diferente daquela do caipira histórico estudado por Candido.

Com efeito, é possível dizer que o narrador somente consegue inverter sua posição de observador do processo de ruína do arraial para observador da submissão dos primos Argemiro e Ribeiro aos ciclos da doença porque eles estão vinculados à propriedade e, por isto, imóveis. Isto significa que, fosse outro contexto histórico, seria possível ao narrador seguir a debandada dos moradores; ou, em termos conceituais, o processo narrativo perseguido seria diverso, conformando possivelmente uma narrativa de diáspora ou de trânsito. Ou seja, ter-se-ia uma narrativa mais tradicional no sentido de que o enfoque seria a agência humana. Cabe a pergunta crucial ao texto, portanto: por que a inversão de perspectiva, dos homens à coisa?

Parte da resposta está apontada acima: há algo que vincula Primo Argemiro e Primo Ribeiro à propriedade. Mais do que isto, há algo que os segura e os junge junto aos seus restos. Uma outra vez, o estudo sociológico de Antonio Candido, Os parceiros do Rio Bonito vem ao auxílio da caracterização deste quadro histórico. Candido relata que uma das fazendas em que fez trabalho de campo, na década de 1950, já fora uma fazenda próspera de café na região de Botucatu, estado de São Paulo, cuja própria trajetória serve como tipo ideal do quadro que o autor tenta esboçar. Diz Candido que a crise de produção de 1902

marca o fim do período áureo da fazenda. Vendida depois da geada de 1918, decaiu cada vez mais. Depois da crise de 1928, passou às mãos de um credor, que a possui ainda hoje, mas não a dirigiu, nem a ela se dedicou até 1948, pois seus interesses comerciais estão em São Paulo. (CANDIDO, 2010, p.131). 
O destino da propriedade, enredada em crises de produção e problemas de crédito, não deixa dúvidas quanto ao seu pertencimento à dinâmica econômica da Primeira República. Mais importante que a simples constatação de seu declínio é, no entanto, a asserção de Candido que vem a seguir: diz o autor que o latifúndio

conheceu o trabalho escravo, o colonato de pretos livres e de imigrantes portugueses. Mas a partir de 1918 deixou propriamente de ser fazenda, isto é, propriedade administrada em que o proprietário explora este ou aquele ramo de atividade agrícola ou pecuária, para se tornar um conjunto de glebas dadas em parceria, sob vigilancia distante (Idem, p.131-132, grifos meus).

O estádio de penúria, portanto, muda efetivamente o regime da mão-de-obra da fazenda observada por Candido: muda também a relação desta mão-de-obra com o estatuto da terra. Com alguma surpresa, o autor assiste ao renascimento daquela mesma sociedade caipira, sustentada em mínimos vitais, num contexto econômico inteiramente diferente da que a originou. Neste sentido, como deixará claro Candido, não se trata de um retorno do arcaico: mas sim de processo novo e que perderia sua especificidade não fosse o cuidado de contextualização histórica. Em suas próprias palavras: "Sobre as ruínas do latifúndio produtivo, na ausência de liderança econômica, a cultura tradicional se refez como cicatriz" (CANDIDO, 2010, p.132, grifo meu).

Interessa-nos aqui esta ideia de cicatrização do tecido social, irrompido pelas crises de produção da Primeira República. A volta à cultura precária de subsistência tem a ver, portanto, com o próprio ciclo de mão-de-obra já descrito nos capítulos anteriores: neste caso, ao contrário do que se encontrou em "A volta do marido pródigo", situa-se o olhar narrativo não sobre o processo de expansão acumulativa, 
mas o de retração. Ou, numa palavra, de crise. A crise e a expansão, no entanto, guardam um senso de coerência interna se, ao atentar-se à cicatriz, percebe-se como ela redefine o estatuto da terra em relação ao trabalho. Ao contrário da situação caipira tradicional, a cultura de subsistência como cicatriz não se liga à farta oferta de terras não ocupadas e ao relativo desinteresse desta produção em relação ao mercado que lhe é externo. No panorama inaugurado pela Primeira República, o ciclo de expansão da produção periférica, que necessita do trabalho para abrir novas fronteiras agrícolas, é o mesmo que também necessita do trabalho de subsistência para garantir a posse da terra como meio de produção ${ }^{40}$. Isto é, estabelece-se uma relação entre proprietários e dependentes que é diferente da neocolonial: aqui, vê-se que ela responde a dinâmicas de expansão e sobretudo retração de mercados vinculados a um contexto que transborda os limites da fazenda.

A ocupação dos moradores, neste sentido, exerce menos uma função produtiva e mais uma função de garantidora do latifúndio como meio de produção: ou seja, ela evita que a terra se comporte como uma cédula de dinheiro que caiu em desuso e que, portanto, perde a capacidade de vincular-se à cadeia de valor. Da perspectiva do morador, este 'retorno do recalcado' somente em aparência lembra a situação caipira tradicional. Este mesmo morador é produto da acumulação primitiva em seu sentido mais forte: ele é fruto do processo de desvinculação do trabalhador dos meios de

\footnotetext{
${ }^{40}$ À primeira vista, o retorno à situação de ocupação precária da terra pode parecer uma contradição com a afirmação de que se trata da transformação da propriedade rural em meios de produção capitalista, e em parte a confusão da crítica ao usar termos como arcaico e moderno vem do embaraço conceitual criado pela situação. Deixaremos a problematização do conceito de modernidade para o último capítulo. Interessa por ora somente o estresse no fato de que produções agrícolas em crise rompem com relações propriamente capitalistas de abstração do trabalho sem no entanto romper com a lógica capitalista como um todo. $\mathrm{O}$ exemplo de Candido é mais uma vez útil neste ponto: a fazenda perde o interesse do patrão face à queda dos preços de produtos do campo, e sua atenção se volta a São Paulo, onde mantém relações de crédito nas quais a fazenda continua funcionando como lastro de suas relações comerciais. O nexo funciona e o valor flui, apoiando-se mesmo sobre os restos da fazenda.
} 
produção: com as terras tomadas por um novo sentido de propriedade privada, seu destino seria o assalariamento em regiões de pujança produtiva - como algumas áreas do café - ou a recaída nesta posição de carência absoluta, na qual ele não tem posse da terra e muito menos recebe o equivalente de seu trabalho na forma de salário ${ }^{41}$. Habitando este limbo produtivo, sua única função na cicatriz do sertão é garantir o lastro da terra ${ }^{42}$ às pulsões de expansão e retração do mercado; inserido como está, todavia, no mercado de mão-de-obra, este morador funciona também como reserva de braços de trabalho e, mais importante, como produtor de mercadorias de subsistência fundamentais.

Este último dado é importante para a caracterização sociológica da cicatriz: Candido chama a atenção, em muitos pontos de seu estudo, à pressão que o mercado exerce sobre o parceiro e o sitiante, inexistente em sua situação tradicional. Diz o autor que estes

agora estão submetidos às vicissitudes da economia geral do estado e do país, com a qual se põem indiretamente em contacto por meio do comerciante, que lhes abre crédito e funciona como comprador dos seus produtos, revendendo-os em seguida aos compradores vindos dos centros distribuidores de produtos agrícolas e pecuários (CANDIDO, 2010, p.192).

\footnotetext{
${ }^{41}$ Ver CANDIDO, 2010, p.252.

${ }^{42}$ Importante ressaltar que, como aponta Candido (ver CANDIDO, 2010, p. 235), desconsiderando os movimentos de migração às cidades ou áreas de agricultura mais próspera, há um intenso movimento de vaivém entre moradores, sitiantes e meeiros entre fazendas na mesma condição econômica. A volubilidade da condição de sitiante não invalida o argumento de que ele está preso a uma circulação entre fazendas nas quais ocupará a mesma posição. Neste sentido, sociologicamente, diz-se que não importa se o trabalhador específico muda de local de trabalho; o que importa é que a situação de dependência se compôs de modo a fazer deste extrato do trabalho um meio de garantir à terra uma produtividade mínima.
} 
Este quadro gera, para o autor, uma situação inimaginável no contexto caipira tradicional: a "construção necessária dum orçamento, ainda que virtual, como a base da economia doméstica" (Idem, Ibidem). A interpretação de Candido, portanto, ganha força ao encarar este quadro paradoxal: enquanto a cicatriz do sertão aparenta um retrocesso a funções coloniais de produção, mimetizando sua penúria produtiva, ela é abraçada por uma rede maior de necessidades produtivas que a pressiona a uma situação de ainda maior precariedade.

Este quadro de nova precarização na cicatriz é o que nos interessa diretamente, pois liga-se à parca possibilidade de assalariamento: como afirmou Candido, o caipira é obrigado a constituir um orçamento, e a única maneira de fazê-lo é subsistir numa situação que o prende à terra arrendada sob o imperativo de produção de subsistência a níveis baixíssimos de produtividade. Como mostra Francisco de Oliveira, a ‘resolução’ deste impasse se dará com as reformas promovidas pelo Estado pós-1930, com as quais se constroem canais de escoamento de mão-de-obra, sendo, por exemplo, a constituição de um salário mínimo peça chave para romper este círculo vicioso no campo e permitir que o trabalho migre em direção à indústria e às cidades $^{43}$. Mas, por enquanto, o que interessa à análise de "Sarapalha" é a situação de cicatriz descrita por Candido, na qual a expressão da crise nos grandes mercados significa um retorno à produção de subsistência que, por um lado, prende o trabalhador a um vínculo de dependência com os proprietários - que assegura a posse da terra como meio de produção ao sustentar este 'retorno do recalcado' - e, diante da impossibilidade de assalariamento, uma nova dependência diante do mercado, que junge o trabalhador ao imperativo de produzir para si e para fora, resultando num alto nível de exploração do trabalho. No fenômeno da cicatriz de Candido, tem-se a

\footnotetext{
${ }^{43}$ Ver Francisco de Oliveira, Crítica à razão dualista, op. cit.
} 
descrição do quadro completo de uma negação ativa, de uma redução a resto que guarda a chave de sua atividade no novo estatuto da terra a partir da Primeira República: sendo meio de produção numa atmosfera de ralo assalariamento, a terra é lugar de expansão agrícola, mas é também depósito de restos de mão-de-obra.

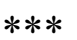

A necessidade de constituição deste quadro histórico parece distante do que "Sarapalha" apresenta como matéria literária. Afinal, pouco se fala de trabalho, produção ou política na novela. O essencial, no entanto, é dirigir a atenção ao efeito de paralisia e redução a resto que a forma tece, evidenciando a relação deste efeito formal, que derivaria seus traços do processo histórico descrito acima, com um artifício literário muito presente na ficção rosiana; a saber, um esboroamento ou mesmo apagamento das evidências históricas de seus textos. Por conta deste procedimento, muitas vezes as narrativas rosianas parecem fechar-se sobre si, num universo formal autocontido que paira no ar. Este traço - a nosso ver, inegável e incontornável - junto a outros - como a extrema erudição do autor e seu gosto por temas religiosos e metafísicos - criaram o ambiente favorável para um tipo de crítica que, no Brasil, floresceu a partir da década de 1970, interessada em vincular a obra de Rosa a tradições filosóficas, psicanalíticas e mesmo místicas.

Da parte da crítica histórica, esta ficou adormecida até a década de 1990, por motivos que aqui não cabe abordar ${ }^{44}$. Seu reaparecimento é de fundamental importância para que uma crítica verdadeiramente formal à obra de Rosa tenha lugar. O dilema que diz respeito ao tratamento de Rosa à história continua a colocar-se

\footnotetext{
${ }^{44}$ Para uma visão mais contundente sobre o difícil panorama crítico de Rosa, ver Danielle Corpas, O jagunço somos nós: visões do Brasil na crítica de Grande sertão: veredas, 2006.
} 
como um canto obscuro de sua obra, com acesso limitado, muito embora leituras de alto alcance crítico tenham se dedicado à empreitada. Um destes trabalhos é o de Ana Paula Pacheco, que abordou o problema da relação entre forma e história em Rosa erigindo o conceito de mito como noção articuladora. Acertadamente, a crítica reconhece se tratar de um problema de perspectiva, pois conquanto as narrativas rosianas dêem ares de imobilidade ainda há um atravessamento histórico desta mesma paralisia:

o mítico surge na dobradiça do foco narrativo ora como mentira, ora como sabedoria, mas também como mentira (que é) histórica, ou seja, visada do mundo que revela, no seu modo de entender/suprimir a História, contradições sociais verdadeiras (PACHECO, 2006, p.19, grifo no original).

Em nota, a crítica deixa clara a sua posição e as consequências do uso do conceito para a análise da obra de Rosa sobre a qual se debruça, Primeiras estórias:

No livro, a revivescência do mito figura ora no universo infantil, ora em pequenos arraiais ou em grandes propriedades rurais onde persistem não só formas arcaicas, ou melhor, residuais, da cultura, como também condições precárias de trabalho e de vida. Não se trata apenas de um remanescente arcaico, no contexto de modernização focalizado pelo livro, mas de elemento constitutivo da nossa modernidade (Idem, Ibidem, grifos meus). 
A afirmação de Pacheco é acertada e toca no nó górdio da interpretação histórica de Rosa. A saber, como se dá essa relação de negação da história de modo que, aporeticamente, ela continue sendo histórica?

A resposta de Pacheco, salvo engano, envereda-se via demonstração de que a própria modernização brasileira contém em si quistos de arcaísmo, sustentando um processo no qual o arcaico ou serve de apoio ao moderno ou é incapaz de desfazê-lo, de modo que seja possível que a própria mentira (isto é, o processo de negação ou recalque do atraso) seja ele mesmo um dado da forma, portanto histórico. A única diferença deste aporte ao que aqui se tenta estabelecer está na própria relação que se estabelece entre atraso e modernidade. Continuando na metáfora psicanalítica, quando o atraso é considerado um conteúdo primitivo que sofre recalque mas continua a existir no 'inconsciente social', não há propriamente contradição no sentido dialético do termo; há o que Ruy Fausto chamou de "oposição real" (FAUSTO, 2003, p.113): isto é, quando atraso e modernidade se opõem realmente, mas sem que esta negação as defina mutuamente. Noutras palavras, deste ponto de vista arcaico e moderno se opõem e a relação é pensada em momentos de forma descontínua (como quebra ou quisto), em outros de forma contínua (arcaico como suporte para o moderno). Mas ela nunca é pensada como contínua e descontínua ao mesmo tempo (como tentamos mostrar acima), de modo a fazer com que o moderno - ou a História - seja definida pela sua negação no atraso, e vice-versa. Em termos menos abstratos, dir-se-ia que, da perspectiva da crítica que se usa do conceito de mito como mentira histórica, a cicatriz do sertão é menos uma criação e mais reminiscência; sua descontinuidade com o resto da produção (o impossível assalariamento) não é considerado uma continuidade das dinâmicas de mão-de-obra. Da mesma forma, não se constrói a 
mediação entre a relação de negação e redução a resto - precariedade - e a acumulação - moderno.

Do ponto de vista de uma crítica dialética, o nó da questão tem de estar numa relação de negação que comporte tanto a continuidade atraso/moderno quanto sua descontinuidade de forma concomitante (expansão de mercados, retração de mercados), e não em momentos separados. Por isto a questão estagnação e processo não pode apresentar-se como oposição simples entre mito e História. Se, desta perspectiva, a narrativa chega a um beco sem saída do ponto de vista processual como é o caso de "Sarapalha" - a compreensão desta frenagem por meio de uma oposição mito e História gera dificuldades. São elas: ou a forma apreendeu um dado positivo do atraso; ou o processo histórico foi barrado via negação, ou nas palavras de Pacheco, mentira.

O impasse que esta via gera, como se disse, reside menos na consideração do atraso como estagnação, e mais na ideia de um movimento que não contempla a negação, e por isto pode aparecer como atraso e, mais importante, não deve pertencer ao moderno. Haveria, portanto, na tentativa de desmitificação do atraso, uma mistificação do moderno que a contrabalanceia ${ }^{45}$. Todo o esforço interpretativo aqui empreendido tem como fim a demonstração de que a desmistificação do arcaico deve resultar, sem ressalvas, numa também desmistificação do moderno, e isto inclui colocar em cheque a própria noção de processualidade, fundamental para a crítica literária e que fundou a própria tradição de análise materialista da literatura. A noção de processo deve abarcar, no sentido dialético acima apontado por Fausto, os

\footnotetext{
${ }^{45}$ Não há nada de errado em manter o dualismo na interpretação de Rosa; é necessário todavia dar-se conta de suas consequências. A mais premente é a assunção de que é possível sustentar, teoricamente, a visão de uma 'modernidade' manca, ou de que o capitalismo brasileiro se comporta de maneira anormal, com setores que se sustentam não obstante o enclave aos processos de valorização. Este pode ter sido o caso de nosso período imperial, mas certamente não é uma visão fiel ao século XX.
} 
momentos concomitantes de continuidade e descontinuidade, nos quais, por exemplo, expansão do café e cicatrização do sertão aparecem passando um no outro e se determinando mutuamente. Desta perspectiva, a ideia de processo deixa de ser um atributo somente da História e passa a ser mediação, como deve ser na crítica dialética. Da mesma maneira, o mito paralisado deve ser visto como abrigando um processo de negação que o atravessa constantemente para a constituição da história capitalista do Brasil do século XX.

O estatuto do mito depende portanto diretamente da caracterização dos processos de negação que ocorrem na obra de Rosa, e não há dúvidas de que há narrativas em que procedimentos que estancam as dinâmicas de apreensão formal de estruturas históricas, funcionando então no sentido denominado por Pacheco, como mentira ou recalque ${ }^{46}$. Mas não é o caso de muitas outras, em que a constituição do sertão como objeto - e não mero assunto literário - predomina. Põe-se assim a hipótese de que o simples tratamento da matéria social 'atrasada' não caracteriza o mito; a mera negação da história (e consequentes estancamentos de processos narrativos) também não é suficiente: como já foi dito, a chave para a questão está no cotejo destes processos negativos de narração com a formalização histórica que eles proporcionam. Neste sentido, "Sarapalha" se destaca talvez de qualquer outro texto

\footnotetext{
${ }^{46}$ Este é o caso, a meu ver, de "São Marcos". O motivo do julgamento desfavorável aos processos míticos nesta novela está diretamente ligado ao traço a que Pacheco chamou a atenção: o modo como o mito pode funcionar como dobradiça perspectiva. No caso de "São Marcos", entende-se que, muito embora sua complexidade, a construção formal e a constituição de tensões dentro do texto acabam refluindo sobre a figura do narrador, que dela sai fortalecido. Isto em si não seria um problema - e certamente não o é, dada a alta qualidade do texto. Um dos motivos no entanto que fazem "São Marcos" não figurar entre as narrativas aqui escolhidas, todavia, é o entendimento de que a construção de uma perspectiva do sertão depende da deposição do narrador como a voz que sintetiza a narrativa e, consequentemente, abre espaço não somente para a voz do outro, mas sobretudo à inclusão das duas vozes narrador e sertanejo - num processo formal que as acolha sob a formalização de processos históricos.
} 
rosiano pela contundência das dinâmicas de 'recalque', e a tipificação de suas negações joga luz sobre esta difícil discussão.

Numa palavra, a reconstituição do argumento de Candido sobre a cicatriz do mundo caipira fornece uma visão sobre o atraso que é ao mesmo tempo modernidade e corte, processo social e crise: acredita-se ser este o chão social que sustenta "Sarapalha". Como se viu, o recalque da produção à condição de cicatriz é menos uma reminiscência e mais uma produção ativa do próprio processo de acumulação levado a cabo na Primeira República e que só se desafogaria muitas décadas depois, com o estabelecimento em bases sólidas da industrialização e de um trânsito estável de mão-de-obra. Como a própria analogia de Candido sugere, a cicatriz é um corte ativo: sua paralisia, portanto, é um processo de negação que em si age sobre o todo da produção. A constatação da natureza das injunções que comprimem o sertanejo ao trabalho precário na terra pode inverter o julgamento sobre a paralisia da novela em questão, consequentemente iluminando os processos míticos de negação e, mais importante, de atribuição de agência às coisas - traços que são notados em "Sarapalha" e que podem figurar sob o guarda-chuva do mito. É o que tentaremos mostrar agora.

Quando o narrador de "Sarapalha" se aproxima de seu objeto, tempo e espaço já foram reduzidos a sua célula mínima. Como que se desfazendo de camadas de pele, o foco narrativo despojou-se da distância temporal e espacial que havia em mãos, jogando para a margem da narrativa todo e qualquer outro aspecto do vilarejo que não 
fosse a simples ação da malária num cenário muito circunscrito: a varanda onde Primo Argemiro e Primo Ribeiro sofrem com os acessos da doença. Neste ponto, torna-se evidente que as personagens são objeto de ação da própria doença; não só porque sua paralisia lhe é devida, mas também porque todo e qualquer movimento subjetivo das personagens por ela é motivado. Da mesma forma, o narrador sai de uma posição de centralidade, daquele que conta o causo, para a posição de anotador dos efeitos do pernilongo e da enfermidade em si:

É de-tardinha, quando as mutucas convidam as muriçocas de volta para casa, e quando o carapanã rajado mais o moçorongo se recolhem, que ele aparece, o pernilongo pampa, pés de prata e asas de xadrez. Entra pelas janelas, vindo dos cacos, das frinchas, das taiobeiras, das bananeiras, de todas as águas, de qualquer lugar ( $\mathrm{S}$, p.153-154, grifo meu).

Em outro trecho, o narrador se aproxima da agência dos ciclos da doença:

Mas, se ele [o mosquito] vem na hora do silêncio, quando o quinino zumbe na cabeça do febrento, é para consolar. Sopra, aqui e acolá, um gemido ondulado e sem pouso... Parece que se ausenta, mas está ali mesmo: a gente chega a sentir-lhe os feixes de coxas e pernas, em linhas quebradas, fazendo cócegas, longas, longas... Arrasta um fio, fino e longínquo, de gonzo, fanho e ferrenho, que vem de longe e dar no longe... Estica ainda mais o fiapo amarelo da surdina. Depois o enrola e desenrola, corpo todo, zonzo, ninando, ninando... E quando a febre toma conta do corpo todo, ele parece, dentro da gente, uma música santa, de outro mundo. (Idem, p.154, grifos meus).

Os trechos são muito ricos em informações sobre esta nova posição do narrador. Com eles, não há dúvidas quanto ao abandono da posição inicial do narrador. Mais ainda: não só este tem como foco a atividade da doença, mas é por ela afetado, de modo a se 
irmanar aos primos Ribeiro e Argemiro, personagens, mas também companheiros do narrador quando o assunto é a pura agência da malária. A narrativa portanto, daí em diante, será diretamente afetada pelos ciclos de febre e pela própria debilidade do narrador, que se ausenta de qualquer posição central e sintética e deixa-se levar pelos mesmos efeitos daquele termo que verdadeiramente segura o bastão da ação na novela.

Este caminho aberto à malária, que subjuga personagens e narrador, é determinante para a temporalidade da narrativa: a partir deste momento, ela se fecha num presente condicionado aos ciclos de febre. Noutras palavras, corta-se qualquer traço de processualidade de maior abrangência. O espaço observa uma cesura também: paralisados, personagens e narrador observam ações que são todas estranhas a suas vontades. Por um lado, a doença com agência própria vem de longe, encurralaos na varanda, de onde se pode observar a dança dos mosquitos nos arredores; por outro, ela age de dentro quando o enxame de protozoários periodicamente ferroa-lhes os baços e ataca-lhes a consciência.

Os cortes espacial e temporal - míticos, dir-se-ia - abrem espaço para a observação das personagens de um ponto de vista muito particular. Submetidos a este encurralamento, o diálogo entre os primos se dá numa chave em que a memória passa a exercer o papel de dobradura dos diversos vetores que ainda continuam operando não obstante o cenário de paralisia. Com efeito, constitui-se uma noção de memória que serve de roldana da relação entre a atividade da doença e o corte da atividade das personagens. Vejamos este movimento: Primo Ribeiro pede ao companheiro que o enterre no cemitério do povoado, pois, não obstante seu estado de abandono, este é ainda "chão de Deus" (S, p.158). Primo Argemiro responde que irá antes dele, mas mesmo assim promete cumprir o desejo do parente se caso for necessário. O tópico da 
morte abre espaço na lembrança de Argemiro para a recordação do que dissera o doutor que lá estivera antes da vila ser reduzida a nada: "Doutor apessoado, engraçado... Vivia atrás dos mosquitos, conhecia a raça deles lá, de olhos fechados, só pela toada da cantiga... Disse que não era das frutas e nem da água... Que era o mosquito que punha um bichinho amaldiçoado no sangue da gente... Ninguém não acreditou..." (Idem, p.158-159). Ele continua:

- Escuta, Primo Ribeiro: se alembra de quando o doutor deu a despedida p'ra o povo do povoado? Foi de manhã cedo, assim como agora... O pessoal estava todo sentado nas portas das casas, batendo queixo. Ele ajuntou a gente... Estava muito triste... Falou: - 'Não adianta tomar remédio, porque o mosquito torna a picar... Todos têm de se mudar daqui... Mas andem depressa, pelo amor de Deus!'... Foi no tempo da eleição de seu Major Vilhena... Tiroteio com três mortes... (S, p.159-160, grifo meu).

Note-se que a memória serve aqui como espaço do presente encurralado em suas relações com os cortes: o corte com a vida funcional do vilarejo, em que um médico veio prestar seu serviço; o corte com a vida política e, consequentemente, com o tempo antes da malária, marcado pelas disputas políticas. Todas estas relações se dão em negativo, mas ao contrário das falas que destacamos no início da análise, não são falas fantasmáticas: ou seja, elocuções sem sujeito a serviço do narrador. Isto porque a memória, neste caso, serve como mediação no sentido que expusemos acima: ela é concomitantemente marca de continuidade com a vida anterior e gesto de ruptura. Sob este enfoque, o mito, em sendo a negação da vida pregressa e a suspensão do tempo neste estado febril, não é mentira histórica, mas o ponto exato em que desenraizamento e vínculo com a terra/produção coincidem. 
Esta tensão entre continuidade e ruptura é, em sua mínima redução formal, representada pelo povoamento de reticências no discurso de Argemiro. As reticências são os momentos em que a memória trabalha como esta dobradura entre o presente ossificado - rompido em sua continuidade, ou contínuo em seu rompimento - e o passado; da mesma forma, as reticências são locais de continuidade/ruptura entre o presente enclausurado da varanda e a vida ampla do povoado. Em outras palavras: entre processo e paralisia.

Porém, talvez mais importante do que tudo isto, é a abertura à fala dos primos e à rememoração, com o artifício das reticências, ao pensamento deslizante entre presente e passado, pavimenta o caminho para a atividade dos restos de que o narrador se despojou. Numa palavra, pode-se dizer que o que sabemos do passado não nos é informado pelo narrador, mas vem das rememorações das personagens febris. Mas o mecanismo descrito acima - em que estas informações nos são mostradas como signo de continuidade/descontinuidade com o passado - nunca poderia gerar o mesmo efeito se o narrador ocupasse posição central e sintetizadora das ações. A auto-debilitação do narrador, portanto, é parte fundamental para o efeito da novela. A narrativa fala, por assim dizer, a partir da própria descamação do narrador. Estes restos não só falam sobre a vida do vilarejo, mas formalmente denunciam o processo de paralisia a que o próprio narrador foi submetido. Neste sentido, não fosse a memória, nada saber-se-ia deste passado e, mais importante, perder-se-ia o efeito formal a que se acede com seu acesso via fala das próprias personagens.

Este efeito simplesmente não existiria se o narrador tivesse se incumbido de sumarizar a história do povoado. O contraste entre paralisia e movimento também seria outro caso fosse este o procedimento: ter-se-ia aquilo que Candido identificou nos escritores regionalistas que precederam Rosa, a saber, uma distinção clara entre 
sujeito e objeto $^{47}$. O que se tem, no entanto, é uma armação narrativa na qual a memória funciona como articuladora de conteúdos ao mesmo tempo em que denuncia o tipo de negação que se opera sobre a novela; neste sentido, o objeto mitificado - a doença, a paralisia, seus efeitos sobre a subjetividade dos sertanejos - passa a todo momento à posição de sujeito: um sujeito que opera via negação e via corte.

Subsidiando por completo esta noção de sujeito, a articulação entre memória, atividade da doença e diálogo em "Sarapalha" lentamente abrirá espaço para que a verdadeira tensão da novela emerja. A menção a Prima Luísa, ex-mulher de Primo Argemiro, é sutilmente introduzida na trama através de um silêncio: "De branco a mais branco, olhando espantado para o outro, Primo Argemiro se perturbou. Agora está vermelho, muito./ Desde que ela se foi, não falaram mais no seu nome. Nem uma vez. Era como se não tivesse existido. E, agora...” (S, p.160, grifos meus). O narrador se incumbe de fazer esta introdução indireta à terceira personagem da estória, mas ele o faz somente porque a articulação entre a doença e as outras duas personagens lhe o permite: o narrador coloca-se ao lado tanto da doença - pois sabe que o estado físico dos Primos talvez não permita mais que eles entretenham alguma conversa fiada como de suas subjetividades - pois ele sabe o que este silêncio significa. O diferente uso dos 'agoras', na mesma passagem, denuncia esta dupla implicação do narrador: da palidez de Primo Argemiro a seu enrubescimento, o narrador sabe que há uma mudança no ciclo da doença; isto é, que um novo acesso de febre lhe espera; já o segundo 'agora' dá conta do momento por ele esperado. A saber, o momento em que a malária reduz aqueles homens a um resto subjetivo, uma escória ${ }^{48}$, e com ela a

\footnotetext{
${ }^{47}$ Ver CANDIDO, Antonio. "O homem dos avessos", op. cit.

${ }^{48}$ Importante lembrar que o uso da palavra escória remete ao processamento de ferro, isto é, um material que resta do processo de fundição das matérias primas como parte irredutível e que não tem mais nenhuma utilidade.
} 
certeza de que esta redução subjetiva permite o surgimento de um conteúdo mnemônico proibido, que enceta uma reviravolta na ação da novela.

Primo Ribeiro confessa:

- É isso, Primo Argemiro... Não adianta mais sojigar a idéia... Esta noite sonhei com ela, bonita como no dia do casamento... E, de madrugadinha, inda bem as garrixas ainda não tinham pegado a cochichar na beirada das telhas, tive notícia de que ia morrer... Agora mesmo, 'garrei a 'maginar: não é que a gente pelejou p'ra esquecer e não teve nenhum jeito?... Então resolvi achar melhor deixar a cabeça solta... E a cabeça solta pensa nela, Primo Argemiro... (S, p.160, grifo meu).

A certeza da morte é também a certeza de que se chegou ao fundo da memória: isto é, o processo de redução estava completo. 'Deixar a cabeça solta', neste sentido, é a entrega a este processo de nenhuma vontade (ou ausência de atividade elocutória) e de mera articulação entre a memória, a doença e os cortes entre presente e passado que ela provocou, trazendo à tona o maior dentre eles: a traição da Prima Luísa. É o registro deste corte que guiará o diálogo entre os primos dali em diante, através do qual a vida da fazenda passa a ser reconstituída:

- Só três anos de casados!... Lembra, Primo Argemiro?... Você veio morar comigo dois meses depois, p'ra plantar à meia o arroz... Eu não tenho raiva dela... Não tenho não. Ainda ficava mais triste, se soubesse que ela andava penando por aí à toa. Agora, o tal, esse... Mesmo doente e assim acabado, eu ainda havia de... (Idem, p.161, grifo meu).

O toque neste conteúdo recalcado passa a abrir, via própria paralisia, as veias da fazenda na reconstrução de sua funcionalidade: sabe-se que o Primo Argemiro veio 
trabalhar na propriedade como arrendado, sabe-se que as obrigações 'legais' de Primo Ribeiro, concernindo a traição, eram 'letra viva' no passado:

- Ai, Primo Ribeiro, por que foi que o senhor não me deixou ir atrás deles, quando eles fugiram? Eu matava o homem e trazia minha prima de volta p'ra trás.../ - P'ra quê, Primo Argemiro? Que é que adiantava?... Eu não podia ficar com ela mais... Na hora, quando a Maria Preta me deu o recado dela se despedindo, mandando dizer que ia acompanhar o outro porque gostava era dele e não gostava mais de mim, eu fiquei meio doido... Mas não queria ir atrás, não... Tive vergonha dos outros... Todo-o-mundo já sabia... E, ela, eu tinha obrigação de matar também, e sabia que a coragem p'ra isso havia de faltar... (S, p.162, grifos meus)

Note-se que este processo de reversão da ação - das coisas às pessoas - se dá como uma passagem do objeto ao sujeito: isto é, a totalidade da vida social interiorana atravessa o resto e se faz saber tão-somente pela inutilidade de todas as informações que reconstroem o quadro da vida anterior da fazenda: àquela altura, qualquer uma das prerrogativas ligadas à traição, vinculadas às expectativas sociais da vingança, já haviam caído totalmente em desuso. Não há mais este outro que é o 'todo-o-mundo' que sabia dos atos de Prima Luísa, que justificava a vergonha de Primo Ribeiro, que poderia motivar sua vendeta. Mais importante do que tudo isto é o fato de estas prerrogativas apontarem em direção a Primo Ribeiro como que se vinculando a um centro colapsado. Os vetores de processualidade da vida social vêm à luz, mas somente como fósseis que nunca emergiriam não fosse o processo de redução a este quisto da memória, que é a traição de Prima Luísa.

Resumindo-se o panorama narrativo, tem-se o seguinte percurso: o narrador posiciona-se a meia distância de um ocorrido que lhe interessa - a história de uma cidade devastada pela malária. A aproximação a este objeto, no entanto, implica a 
instância narrativa no acompanhamento da redução do vilarejo a resto, o que paulatinamente a coloca ao lado das personagens, premida sob o efeito negativo das injunções que agem sobre a vila, e sob a agência da própria malária, que ganha protagonismo. Desta posição, ao lado das personagens, debilitado, o narrador dá formas ao processo mitificante de entregar o sujeito da ação às coisas e objetificar os processos humanos.

Deste lugar em que o narrador é incapaz de sintetizar processos humanos, abre-se espaço para que a memória das personagens funcione como o próprio dispositivo que atualiza o processo de negação sofrido, ao trazer ao presente os fósseis da vida pregressa: estes mesmos fósseis são os elementos da vida social que foram negados e que, deste lugar de inutilidade, reconstituem a posição das personagens de meros objetos paralisados pela doença a sujeitos que foram alienados dos processos sociais de que participavam - a produção, a vida política, os dilemas amorosos etc. Reconstrói-se, da noção de corte como alienação, um novo lugar para a estória no qual a agência narrativa é disputada entre a malária e a memória: melhor dizendo, a malária e seus ciclos de febre contribuem para a atualização dos antigos dilemas - a querela em torno da Prima Luísa em seu centro - de modo que a noção de sujeito oscila entre a doença e as personagens, revertendo a posição inicial da narrativa.

A tensão verdadeira da trama acontece portanto neste novo cenário em que a febre impulsiona a atividade da memória e assim presentifica um objeto de disputa entre os primos. Objeto que não reverte sua condição de fóssil mas atua atravessando a debilidade. Veja-se como isto se dá: logo após a memória acessar o quisto da traição de Prima Luísa, Primo Ribeiro entrega-se ao ciclo de febre e assim fica 
inacessível ao diálogo. Neste momento, é a memória de Primo Argemiro que passa a funcionar, atualizando o seu conteúdo recalcado:

Primo Ribeiro se deixa cair no lajedo, todo encolhido e sacudindo de tremor. Primo Argemiro fica bem quieto. Não adianta fazer nada. $E$ ele tem muita coisa sua para imaginar. Depressa, enquanto Primo Ribeiro entrega o corpo ao acesso e parece ter partido para muito longe d'ali, não podendo adivinhar o que a gente está pensando. (S, p.163, grifo meu)

Neste momento dá-se uma virada crucial na narrativa. Os pensamentos de Primo Argemiro passam a se confundir com as palavras do próprio narrador, procedimento que dá ênfase à emergência do conteúdo recalcado e relega o papel da doença ao lugar que antes ocupava o próprio narrador, que é o de suporte da ação.

E Primo Argemiro sabe aproveitar, sabe correr ligeiro pelos bons caminhos da lembrança./ Como era mesmo que ela era?!... Morena, os olhos muito pretos... Tão bonita!... Os cabelos muito pretos... Mas não paga a pena querer pensar onde é que ela pode estar a uma hora destas... Quando fugiu, que baque! Que tristeza... Não esperava aquilo, não esperava... Parecia combinar bem com o marido... Primo Ribeiro naquele tempo era alegre... E ele sentira até ciúmes de Primo Ribeiro, ciúme bobo, porque Primo Ribeiro era quem tinha o direito a ela e ao seu amor... (Idem, Ibidem).

O cenário de reversão da debilidade em ação é completo: o novo arranjo joga a cena na ebulição de afetos atuais que somente vêm à tona graças aos ciclos da maleita. Primo Argemiro restitui todo o microuniverso da fazenda a partir de seu acesso, e com isso a noção de processo volta à narrativa: o processo de enamoramento pela mulher do Primo, o tipo de angústia que isto lhe causa, os dilemas éticos ligados à traição, à posição de Primo Ribeiro como proprietário etc. 
Primo Argemiro já se acostumou com o trincar de dentes e com os gemidos de Primo Ribeiro. Não pode dar-lhe ajuda nenhuma. O que pode é pensar. E pensa mais, quase cochilando, gemendo também, com as ferroadas no baço. Pensa à toa, como os tico-ticos, que debicam na terra ciscada por galinhas, e dão carreirinhas tão engraçadas, que a gente nem sabe se eles estão cruzando aos pulinhos ou se é vôo rasteiro só./ ... Não adiantou ter sido tão direito... Se ele, Primo Argemiro, tivesse coragem... Se tivesse sido mais esperto. Talvez ela gostasse... Podia ter querido fugir com ele; o boiadeiro ainda não tinha aparecido... Agora, ela havia de se lembrar, achando que era um pamonha, um homem sem decisão... E, no entanto, viera para a fazenda só por causa dela... Primo Ribeiro não punha malícia em coisa nenhuma... Sim, os dois tinham sido bem tolos, só o homem de fora era quem sabia lidar com mulher!... (S, p.165, grifos meus).

O número de movimentações narrativas neste trecho é vertiginoso. Nota-se primeiro que o narrador está inteiramente inserido dentro do processo mental de Primo Argemiro, de modo que seu próprio pensamento oscila entre o assunto que the interessa - a querela envolvendo a Prima Luísa - e passagens analógicas que falam sobre o próprio modo de se pensar sob a febre - como passarinhos ciscando, pulando de um pensamento a outro. O deslize sem mediações para a psique de Primo Argemiro quase transforma a novela em um texto em primeira pessoa, no qual as ciscadas mentais dão o tom de uma processualidade mole, que rodeia o assunto que reconstrói todo o cenário de tensões na fazenda. Por fim, tem-se um dado importante: a marcação desta personagem obscura, o boiadeiro, como homem de fora, o homem com decisão.

A figura desta personagem que leva Prima Luísa delimita a própria inscrição da fazenda de Primo Ribeiro num contexto funcional de produção: ou, se falarmos com o narrador, marca seu pertencimento nos mapas, já que insere a fazenda no quadro de circulação de pessoas e mercadorias no interior. Tem-se portanto mais uma 
vez a figuração do corte sobre o qual a novela versa: o conteúdo recalcado de maior envergadura é precisamente o contato da fazenda com seu exterior. É neste ponto de contato, portanto, que o luto e, depois, a malária atuou.

A determinação de um limite entre dentro e fora da fazenda pode passar desapercebida, mas assume um significado notável face à discussão que se fez sobre a natureza das forças que exercem a redução da fazenda a resto e seu consequente enclausuramento numa célula débil de ação. Esta ação determinante, vinda de fora e que sela o destino dos dois primos à amargura do luto e, pode-se dizer, à atividade da maleita, é traço marcante em Sagarana. Existe, grosso modo, uma disposição formal que delimita o espaço do sertão no local da passagem ou de limite entre dentro e fora: é o que vemos em "Sarapalha", é o que vemos em outras novelas.

Em "Duelo", por exemplo, o arranjo narrativo poderia muito bem ser considerado o inverso de "Sarapalha": a ação de perseguição e vingança atua no sentido de delimitar muito bem seu espaço de possibilidade. A posição do narrador é segura e estável durante a maior parte da novela, na qual acompanha a perseguição de Cassiano a Turíbio Todo de modo a configurar um tom leve e até mesmo engraçado ao jogo de gato e rato que as personagens proporcionam. Mas quando as duas personagens extrapolam este espaço delimitado - Turíbio parte para São Paulo para trabalhar na lavoura do café, Cassiano adoece num vilarejo esquecido e muito pobre vê-se que o estatuto da ação muda de figura, bem como o posicionamento do narrador. A novela perde seu tom leve e cômico e dá lugar à hagiografia (que será discutida nos capítulos a seguir). O que importa neste momento é a identificação de uma clara distinção entre dentro e fora: dentro do espaço de perseguição, as expectativas de vingança, suas consequências, são moeda comum e de conhecimento de todos que habitam este espaço. Fora dele, Turíbio se engaja em atividade 
assalariada; Cassiano tenta contratar um matador para dar conta de sua vingança sem sucesso, pois a pobreza da vila onde se encontra a faz desconhecer este tipo de atividade.

A virada hagiográfica em "Duelo" se dá precisamente neste ponto de contato, onde o narrador perde seu esteio inicial como observador/contador de causo, a novela perde seu tom cômico e a vingança muda totalmente de figura. Neste sentido, toda a circunscrição de um espaço inicial de ação é subvertida em função de seu próprio extrapolamento. Encontra-se aqui a mesma lógica que, em "Sarapalha", está reduzida à sua fórmula mínima. A saber, a delimitação da forma numa relação entre dentro e fora, esquema no qual o narrador exerce importante papel como voz distante ou do outro, serve para sua posterior subversão na qual dentro e fora se confundem numa relação de continuidade/descontinuidade simultânea, como vimos. No caso de "Duelo", as duas partes do texto são relacionadas pela noção de vingança, que continua a acompanhar a trama mesmo depois do desmonte de sua estrutura inicial. Mas a vingança como infinita perseguição da primeira parte da novela não é a mesma vingança hagiográfica de seu final: dentro do círculo demarcado pela narrativa, a vingança como perseguição é possível; fora dele, ela é impossível. A vingança hagiográfica, ao marcar uma linha de continuidade entre possibilidade e impossibilidade, é certamente um artifício literário de alto alcance. Mas é também o registro da forma da própria apreensão da ideia de sertão como esboroamento. $\mathrm{Ou}$, em termos mais precisos, do ponto de continuidade e descontinuidade entre o mundo rural e o sistema capitalista. Exatamente por ser um ponto paradoxal - contínuo, descontínuo - esta noção de sertão, em muitos momentos da crítica, teve de ser abordada com conceitos que articulassem o que está dentro do mundo rural - arcaico - ao que está fora - moderno. Perde-se no entanto, com esta abordagem, o momento 
de configuração do sertão como movimento de passagem do dentro no fora, do fora no dentro: a saber, perde-se a dialética na noção de alienação, que reside neste momento de passagem. Em "Sarapalha", o sertão se configura portanto como objeto em cada momento de corte e negação, de paralisia e rememoração, nos quais se torna explícita a continuidade forjada sobre o descontínuo da paralisia. A subjetividade das personagens em "Sarapalha" torna-se o ponto de dobradura do sertão, em que dentro e fora passam um no outro.

O sertão, ao contrário de Grande sertão: veredas, em Sagarana não está em toda parte: ele é acessado via uma série de deslocamentos que, em suma, podem ser resumidos à deposição do narrador como figura sintética e aproximação da perspectiva do sertão descrita acima. Falar em 'perspectiva do sertão' pode parecer um tanto vago: mas, ao contrário de uma determinação geográfica ou mesmo sociológica - ambição de localização conceitual que conduziu Euclides da Cunha, por exemplo -, chama-se a atenção para a maneira como o sertão se constitui formalmente como processo que exatamente media estas relações entre dentro e fora. Seja através de casos claros em que o narrador se coloca como perspectiva de fora caso de "Minha gente" ou "Corpo Fechado" -, seja por mecanismos mais complexos, como vimos em "Sarapalha".

A questão para Rosa, portanto, não pode se resumir num abismo entre escritor culto e matéria atrasada, pois a forma rosiana atesta o contrário: como se viu, a ação de dispositivos narrativos tem como fim a deposição deste abismo que traz a proscênio a imagem de um processo que, em seus melhores resultados, engloba tanto 
sertanejos quanto o narrador. Em outras palavras - e em "Sarapalha" isto é mais do que claro - a narrativa opera uma transformação nas posições e estatutos do narrador e personagens, de modo que o final do texto confronte o seu início e o obrigue a uma releitura à luz do processo que emergiu como efeito final. Ou seja, toda a construção inicial reflui ao início da narrativa como perspectiva do sertão.

A novela aqui analisada é sem dúvida a que apresenta a maior dificuldade de análise. Ela conta com inúmeros processos simultâneos de negação e redução à debilidade para, ao fim, abrir-se de maneira surpreendente. Neste ponto a leitura que Candido faz do processo de cicatrização sertaneja reaparece como chave de leitura para se entender, primeiro, por que a constituição de uma perspectiva processual que mira o sertão assume estas feições; segundo, o porquê de sua abertura. A cicatriz, como se viu, é um enclausuramento ao uso precária da terra; ela é, sobretudo, a medida de uma necessidade - a acumulação primitiva - vinculada a uma impossibilidade que caracteriza a Primeira República: aquela de assalariamento. É por este motivo que se diz que talvez a conceituação de Candido sobre a cicatriz tenha sido aquela que melhor tenha apreendido a ideia de sertão: exatamente porque condensa, num conceito, uma possibilidade e uma impossibilidade simultâneas. Tendo a relação da cicatriz com os aspectos totalizantes da economia brasileira bem esboçados, é difícil admitir este quadro como sendo uma simples figuração do atraso: a atividade de compressão que sofrem os sertanejos é nítida, e ela tem a ver com as dinâmicas de expansão e retração de um mercado que transborda os limites da cicatriz.

Esta compressão aliada à impossibilidade é o que gera seu quadro paradoxal e que, acredita-se, explica o transbordamento dos processos narrativos ao final de "Sarapalha": trata-se, de um lado, de uma compressão necessária e, por isto, uma 
pressão vinda de fora; mas na medida em que se põe como movimento geral de compressão da mão-de-obra, este mesmo processo excede os limites da propriedade rural e exige um embaralhamento das mesmas fronteiras que a cicatriz tratou de criar. Isto é, se da perspectiva do sertanejo a compressão pode ser encarada uma força alheia à sua vontade que o limita a uma vida de precariedade, de uma perspectiva processual ela deve marcar uma continuidade com o movimento geral de crises e acumulação da economia brasileira.

O fecho de "Sarapalha" nos dá o espelhamento formal deste processo. A agência da malária - isto é, a compressão de fora - enseja o momento de confissão de Primo Argemiro. O narrador, com sua voz misturada à da personagem, dá conta do contexto da confissão como um último ato que precede a total constrição da personagem diante deste processo de redução: a saber, a morte. Ele diz, sobre a febre que começa a agir sobre Primo Argemiro:

Sim, d'aqui a pouco vai ser sua hora. Aqui a febre serve de relógio. Ele já está ficando mais amolecido. Também deve ser de ter pensado muito. Antes o outro não tivesse querido falar em nome guardado... Foi dar outra força à saudade... E ele, que nem tem com quem desabafar, não tem a quem contar seu sofrimento!... Lá, onde está o cruzeiro, morreu um trabalhador de roça, um velho. Foi de repente, do coração... Será que a gente ainda tem de viver muito?... (S, p.168, grifos meus).

Vê-se como a agência de fora, a maleita, engendra o processo interno que, enfim engatilha a confissão; isto é, a ação propriamente dita:

- Eu... eu também gostei dela, Primo... Mas respeitei sempre... respeitei o senhor... sua casa... Nós somos parentes... Espera, Primo! Não foi minha culpa, foi má-sorte minha.../ Primo Ribeiro arregalou os olhos. Calcou a mão na madeira do cocho. Faz força para se 
levantar./ - Não teve nada, Primo!... Juro!... Por esta luz!... Nem ela nunca ficou sabendo... Por alma de minha mãe! [...] - Fui picado de cobra... Fui picado de cobra... Ô mundo!/ - Mas, sossega, Primo Ribeiro... Já lhe jurei que não faltei nunca ao respeito a ela... Nem eu não era capaz de cair num pecado desses.../ - Fui picado de cobra.../ O senhor está variando... [...]/ - Não estou variando, não, mas emantes estivesse!... Some daqui, homem! Vai p'r'as suas terras... Vai p'ra bem longe de mim!... Mas vai logo de uma vez! (Idem, p.169170 , grifos meus).

A ação desabrocha deste emaranhado de inação, tal como as prerrogativas sobre a posse da terra são desentranhadas de seu resto. Da mesma forma que o boiadeiro, vindo de fora, não respeita a prerrogativa de posse da terra - e consequentemente posse das pessoas ligadas a ela -, o que este último ato da novela produz é também uma confusão e esboroamento sobre a ideia de propriedade e as prerrogativas que com ela caminham. A querela é familiar e esta aponta para o centro da propriedade demandando uma resolução: com efeito, a última cartada de Primo Ribeiro é apelar para estas prerrogativas, não obstante sua total falta de lastro. Mas a negação deste estatuto, que percorreu todo o texto, fá-lo estacionar precisamente neste ponto de concomitância entre posse/não-posse, que é exatamente a situação de cicatriz. A novela portanto encaminha seu desfecho para um cenário de impossibilidade, no qual as prerrogativas legais sobre a propriedade existem somente em modo fantasmático.

Primo Argemiro obedece, mas a cena que descreve sua saída não resulta na demarcação daquele espaço como sendo um dentro sobre o qual se tem jurisdição. Muito pelo contrário: o embate entre dois moribundos, com um deles deixando o espaço da varanda, mostra-se exatamente como isto, um caminhar por uma terra sem dono. 
Primo Argemiro reúne suas forças. E anda. Transpõe o curral, por entre os pés de milho. Os passopretos, ao verem um espantalho caminhando, debandam, bulhentos. O perdigueiro de focinho grosso vem correndo também. Vem, mas diz que não vem: vira a cabeça, olha para Primo Ribeiro, que lá está sentado ainda, curvado para o chão. O cachorro está desatinado. Pára. Vai, volta, olha, desolha... Não entende. Mas sabe que está acontecendo alguma coisa. Latindo, choramingando, chorando, quase uivando. Porque tem ordem de ser sempre fiel, e não sabe mais, não se recorda mais qual dos dois homens será seu dono verdadeiro. (S, p.171, grifos meus)

De modo sutil, o narrador novamente retira a agência dos homens e a transfere à coisa, colocando sobre a subjetividade do cachorro uma posição de indecidibilidade que não the diz respeito. A narrativa, ao invés de se fechar sobre a propriedade, conduz ao efeito contrário: sua abertura é, de fato, uma abertura da situação de resto para além dos confins da fazenda sob o signo do embaralhamento definitivo das vozes do narrador e de Primo Argemiro:

... Por aquele tempo, Argemiro dos Anjos era um moço bemaparecido, de figura, e com oitenta alqueires de terras de cultura, afora algum dinheiro de parte.../ Ai! que o frio cai entre os ombros, $\mathrm{e}$ vai pelas costas, e escorre das costas para o corpo todo, como fios de água fina. Zoa nos ouvidos confuso sussurro, e para diante dos olhos vêm coisinhas, querendo dançar (S, p.172-173, grifo meu).

Esta abertura joga uma última luz novamente sobre a articulação entre passado e presente, deixando claro que o que aquele espantalho carrega como negação é precisamente uma noção de pessoa que se ligava à posse da terra. $\mathrm{O}$ contraste disto com a total indeterminação é o verdadeiro efeito da novela:

Ir para onde?... Não importa, para a frente é que a gente vai!... Mas, depois. Agora é sentar nas folhas secas, e agüentar. O começo do 
acesso é bom, é gostoso: é a única coisa boa que a vida ainda tem. Pára, para tremer. E para pensar. Também./ Estremecem, amarelas, as flores da aroeira. Há um frêmito nos caules rosados da erva-desapo. A erva-de-anum crispa as folhas, longas, como folhas de mangueira. Trepidam, sacudindo as suas estrelinhas alaranjadas, os ramos da vassourinha. Tirita a mamona, de folhas peludas, como o corselete de um caçununga, brilhando em verde-azul. A pitangueira se abala, do jarrete à grimpa. E o açoita-cavalos derruba frutinhas fendilhadas, entrando em convulsões./ - Mas, meu Deus, como isto é bonito! Que lugar bonito p'r'a gente deitar no chão e se acabar!... / É o mato, todo enfeitado, tremendo também com a sezão (Idem, p.173, grifo meu).

Não é surpreendente que este trecho, embora breve, lembre em muito a posição do narrador em Grande sertão: veredas e, mais ainda, o efeito poéticodescritivo que caracteriza aquela obra. Com efeito, o que se pode dizer como palavra final é que o caminhar sobre esta linha de indecisão que caracteriza a situação de cicatriz não assegura a noção de propriedade; pelo contrário, pode-se dizer que toda a preparação narrativa em "Sarapalha" se dá em função deste momento em que as condições descritas na fazenda se espalham para além de seus confins. Tem-se aí uma indicação de que o sertão não é o mundo como condição a priori. O processo de negação do sujeito, neste caso, acompanha Primo Argemiro e se estabelece como condição necessária para que haja esta poesia descritiva ao final: ou seja, o processo de mitificação - a contaminação da natureza pela malária - é apenas um efeito da forma no acompanhamento da cicatrização como processo social, no qual as fronteiras da produção rural vão sendo abertas sobre esta trilha de indefinição quanto à ideia de propriedade e, consequentemente, de pessoa e subjetividade. A malária que contamina um terreno vasto, sem cercas, onde as coisas têm agência comprimindo o sujeito e expandindo o horizonte, é apenas uma maneira de afirmar: o sertão 
transborda o leito da Primeira República acompanhando o destino do trabalhador rural no caminho de um chão social impossível. 


\section{Conversa de bois}

Segundo Guimarães Rosa, em carta a João Condé, "Conversa de bois" foi uma narrativa inicialmente escrita para figurar em Sezão, obra de 1937 que seria a base de Sagarana nove anos depois. A versão anterior - texto que envolvia também "carros, bois, carreiro e guia" (S, p.27) - fora, segundo o autor, "definitivamente sacrificada", dando lugar à versão que conhecemos em Sagarana. A declaração, para além do interesse na análise dos processos criativos do autor, pode dizer muito sobre a narrativa em questão. Com efeito, vemos os mesmos elementos citados pelo autor, contidos na narrativa original, em outras novelas - "Burrinho pedrês" e "Minha gente", por exemplo - mas nenhuma carrega a complexidade formal de "Conversa de bois", o que pode explicar em parte o descarte da ideia anterior e a necessidade de sua estrutura ser totalmente repensada. Temos, de início, somente a pista de que a relação entre animais e trabalho será abordada pela novela: mas esta mesma relação escondese à sombra de múltiplos movimentos narrativos que dificultam-lhe um acesso direto. 
À primeira vista, o que se pode falar sobre "Conversa de bois" é que se trata do texto em que a noção de alegoria é ativada com maior seriedade do que em outros textos que compõem Sagarana. E, neste sentido, a alegoria carrega consigo a já mencionada discussão sobre o mito, dado que se trata de uma narrativa em que animais ganham vozes e possibilidade de ação tão potentes quanto a de humanos. Há, no entanto, um dado fundamental da elaboração formal em "Conversa de bois" que não pode ser omitido e que talvez remeta à grave reestruturação a que o autor fez menção. Há uma cena que se estabelece logo de início na qual o narrador se enche da impostura fabulesca e, logo em seu primeiro parágrafo, estabelece a expectativa de que o que se encontrará à frente é a estrutura de uma narrativa tradicional, à moda dos contos de fada:

Que já houve um tempo em que eles conversavam, entre si e com os homens, é certo e indiscutível, pois que bem comprovado nos livros das fadas carochas. Mas, hoje-em-dia, agora, agorinha mesmo, aqui, aí, ali, e em toda parte, poderão os bichos falar e serem entendidos, por você, por mim, por todo o mundo, por qualquer um filho de Deus?! (S, p.325).

O tom do narrador logo de cara levanta suspeitas: trata-se, ao mesmo tempo, de um narrador culto, com conhecimento da tradição a que se refere, mas também angustiado pela matéria que move sua questão narrativa. A expectativa estrutural também carrega uma perspectiva de tratamento temporal da matéria: espera-se que ela se dê quase ao modo de um tratado ou ensaio, no qual o narrador exporá seus pensamentos a respeito da matéria de modo a submeter exemplos específicos - no qual animais falam ou não falam - a uma cadeia de causalidades lógicas que pode provar ou refutar seu argumento. 
Toda esta expectativa é de chofre quebrada com o parágrafo a seguir, no qual se tem notícia de que o narrador não se encontra sozinho, mas imerso numa situação dialógica: “ - Falam, sim senhor, falam!...” (Idem, Ibidem). A inserção deste outro exerce um corte em todas as expectativas anteriores: tanto no que diz respeito à temporalidade da narrativa - a suspensão dá lugar à presentificação das conjecturas quanto ao posicionamento do narrador frente às mesmas. Com efeito, este outro parece interromper as divagações do narrador e mesmo sua pretensão de levar a cabo o raciocínio por conta própria. Trocando em miúdos, o aparecimento de um outro e da situação dialógica lança a ideia de causalidade e constituição de um pensamento sob o registro de uma outra chave, dado que se mostrará importante à frente.

O mesmo narrador que pretendia se lançar à fábula é obrigado então a caracterizar o outro que interrompe seu discurso:

afirma o Manuel Timborna, das Porteirinhas, - filho do Timborna velho, pegador de passarinhos, e pai dessa inifinidade de Timborninhas barrigudos, que arrastam calças compridas e simulam todos o mesmo tamanho, a mesma idade e o mesmo bom-parecer; Manuel Timborna, que em vez de caçar serviço para fazer, vive falando invenções só lá dele mesmo, coisas que as outras pessoas não sabem e nem querem escutar (S, p.325, grifo meu).

A caracterização é rica não somente porque detalha o outro dialógico, mas sobretudo porque insere sua fala e mesmo o objeto da conversa num registro muito diferente do inicial. Manuel Timborna é personagem da mesma extração que outros em Sagarana, um espectro que pode compreender desde Lalino em "A volta do marido" a Manuel Fulô em "Corpo fechado". Trata-se de sertanejos sem ocupação definida, que flutuam no espaço social do sertão e talvez por isso sejam a melhor fonte de conteúdo para causos. É claro, o julgamento do narrador sobre Timborna também caracteriza o 
primeiro como alguém de fora e que, portanto, consegue qualificar tanto o assunto da conversa como a situação em que ela ocorre como fruto da falta de ocupação, i.e. produto de uma mente não disciplinada pelo trabalho.

Esta caracterização é importante por motivos que ficarão claros à frente quando o estatuto do causo será afastado da conversa fiada e se aproximará de uma representação mais séria. Por ora, cumpre notar que certo escárnio na caracterização de Timborna reflui sobre o próprio narrador e suas divagações cultas do primeiro parágrafo: certamente o tom bacharelesco de sua fala é trazido ao rés-do-chão pela intervenção do sertaneja e pela introdução do diálogo. Veja-se como ele prossegue:

\begin{abstract}
- Pode que seja, Timborna. Isso não é de hoje:... "Visa sub obscurum noctis pecudesque locutae. Infandum!..." Mas, e os bois? Os bois também?.../ - Ora, ora!... Esses são os que mais!... Boi fala o tempo todo. Eu até posso contar um causo acontecido que se deu./ - Só se eu tiver licença de recontar diferente, enfeitado e acrescentado ponto $e$ pouco.../ - Feito! Eu acho que assim até fica mais merecido, que não seja (S, p.325-326, primeiro grifo no original, segundo grifo meu)
\end{abstract}

É evidente que a citação de Virgílio em latim estabelece uma disparidade entre os dois falantes, bem como o tom condescendente do narrador ante o sertanejo. Importante notar no entanto que o desejo de ambos era o mesmo: divagar sem muito lastro sobre um assunto qualquer, somente um ensejo para a continuação de uma conversa que, ao que tudo indica, já acontecia antes de a narrativa se iniciar. Tem-se portanto a situação na qual a erudição do narrador é submetida ao registro do causo não por compaixão ao outro que fala, mas simplesmente porque - como a citação latina confirma - ela não encontra qualquer repercussão simbólica naquele lugar social. 
$\mathrm{O}$ 'trato' feito entre ambos, por isso, não é um trato que serve à nivelação dos dois registros por vontade do narrador de dar ao causo o mesmo estatuto narrativo que ele encontra em Virgílio, por exemplo. Mas é um trato que esboça o local de onde ambas as vozes falam: um lócus em que o tom bacharelesco, sem sustentação, tem de se nivelar ao do causo. Novamente, o efeito deste embate entre as vozes acaba revelando que tanto a erudição quanto o causo servem à conversa fiada por sua estrutura de pensamento: solta, descomprometida, auto-afetiva e desinteressada pelo objeto. A própria insustentabilidade de perspectivas distintas, materializadas como discursos de fora e de dentro do ambiente sertanejo, revela menos a boa-vontade do narrador e mais o próprio setting em que ambas as vozes encontram-se neste lugar de descompromisso no qual o causo é possível: o ambiente em que a noção de trabalho abstrato e disciplina mental é frouxa.

Outro aspecto crucial deste trato concerne o estatuto dado à ficção como intervenção na matéria do causo. O narrador aceita ouvir a estória de Timborna, contando com a possibilidade de 'enfeitá-la' e talvez transformar seu conteúdo de modo a torná-la digna das altas narrativas que o narrador tem em mente: a pergunta que resta, a esta altura, é se a trama preservará a mesma estrutura do pensamento bacharelesco, ao final retornando ao narrador e encarregando-o de extrair da estória um sumo lógico e moral. Cabe ao desenvolvimento da novela a tarefa de conformar esta noção de ficção como embelezamento ou de subverter a armação inicial de "Conversa de bois". 
Com o início do causo, dá-se lugar a uma mudança drástica de perspectiva narrativa. A investidura antes assumida por Timborna é logo passada à voz de uma irara que casualmente "rolava e rodopiava, acabando de tomar banho de sol e poeira" à beira de uma estrada. O fato de a voz ter sido dada a um animal, é claro, já corrobora com o assunto da prosa anterior, já colocando toda a narração como 'prova' do ponto que Timborna gostaria de fazer. Mas a simples mudança de ponto de vista não constitui matéria de um causo, que, como prometido pelo sertanejo, deve exibir uma prova da conversa dos bois. A fortuidade com que o animal encontra sua matéria narrativa quando o carro-de-bois passa pelo cachorrinho-do-mato deve portanto, por ora, ser guardada como dado quando casualidade e necessidade se confrontarem no decorrer da novela. $\mathrm{O}$ que se pode dizer à esta altura é que a passagem de voz à irara por um lado joga com o sentido anteriormente atribuído à ficção como um floreio. Mas sobretudo ela trabalha com a primeira noção de animalidade a aparecer na novela: a de um ponto de vista que pode acompanhar a ação - que decorre em trânsito, importante dizer - de forma neutra e desinteressada. Quando a caravana passava pela irara, ela teve de decidir se a acompanhava ou não: entra em jogo um novo sentido de negociação, que desta vez acontece entre o animal e Timborna, que depois do acontecido captura o cachorrinho e só promete sua liberdade "a troco da minuciosa narração" (S, p.329). A negociação decerto ainda acontece no registro da fábula - ou melhor, da história de pescador. Mas o fato surpreendente é que, desta vez, ao contrário do primeiro trato, ela se dá às custas da perda do sentido inicial de fortuidade do encontro com a matéria narrada e da assunção de um compromisso com a minúcia; isto é, com a objetividade que garanta à ação o status de ficção.

Este primeiro sentido da animalidade é sutil mas fundamental para o curso da trama, pois reconstitui sorrateiramente uma posição narrativa que escapa à situação 
dialógica inicial, na qual as posições de fora e de dentro do local de ação se chocam na busca pela autoridade narrativa. Cria-se, portanto, mesmo que paradoxalmente, um ponto de vista objetivo para a narrativa dos fatos; isto é, um ponto de vista terceiro que pode, ao cabo, desafiar o próprio sentido de ficção estabelecido pelo interlocutor culto. Este ponto de vista muda a chave de interesse pelos fatos da mera casualidade para a necessidade: isto porque, fosse Timborna a testemunha dos fatos narrados, toda a trama continuaria no registro do causo e, como se disse, restaria ainda como significante em disputa com o interlocutor culto. Isto significa que a objetividade da narrativa não se deve somente à agilidade da irara e sua malícia, que promovem o acompanhamento próximo dos fatos. Ela se deve sobretudo à retirada da voz do registro humano e de sua colocação em uma instância outra. A saber, o espaço da conversa fiada, no qual o estatuto da narração como causo deve sua forma à parca mediação a que é submetido e no qual o caráter divertido ou intrigante do narrado tem a ver com o próprio descompromisso de quem narra. Trocando em miúdos, à pergunta que decerto se deve fazer ao texto - por que colocar a narrativa na boca de um animal? - se deve responder: para subverter a noção de causo e sua consequente indolência narrativa, retirando o estatuto da ficção tanto das mãos do interlocutor culto quanto das mãos do capiau. Esta nova ideia de ficção flutua portanto entre a mera imaginação do sertanejo e a invenção engenhosa do intelectual, o que de fato constitui o espaço para alegorização da animalidade que está por vir.

Após o estabelecimento da perspectiva animal como mediadora e capaz de descrição detalhada dos fatos, um novo objetivo narrativo se arma aos poucos. Ele é, a princípio, configurado como uma aproximação ao carro-de-boi e à cena que sobre ele é sustentada. Tudo começa com um apelo à descrição: 
Começou, porém, a esquentar fora da conta. Nem uma nuvem no céu, para adoçar o sol, que era, com pouco maio, quase um sol de setembro em começo: despalpebrado, em revelo, vermelho e fumegante. / Então, Brilhante - junta do contra-coice, lado direito coçou calor, e aí teve certeza de sua própria existência (S, p.329, grifo meu).

Note-se que a consciência do boi é despertada pelo calor que o narrador-animal também pode perceber. O efeito do cenário sobre o boi - isto é, a percepção possível ao animal de que está muito quente - abre ao narrador uma porta a sua subjetividade. O embate com a natureza, neste caso, cumpre-se a evidenciar uma primeira clivagem na mente bovina: rachadura básica, mas que já constitui o terreno de mediação entre a mera descrição e a alegoria.

O boi Brilhante sente calor, sobretudo por seu pelame negro. A pura afecção sensorial contextualiza seu desejo de "querer toda vez, no pasto, a sombra das árvores" (S, p.330). Do desejo de alívio do calor, desce-se mais um degrau em sua consciência: o boi se lembra, associativamente, que tais lugares são no entanto perigosos, repletos de moscas que o fazem se ver às voltas com bernes e bicheiras. Há também ervas venenosas, que lhe exigem uma pastagem cuidadosa. Brilhante se lembra do irmão Tubarão, morto há um mês e meio, "ervado de timbó" (Idem, Ibidem). A lembrança abre outra porta, um luto pessoal pela morte do irmão, o que, aliado às bernes, explica seu temperamento difícil como boi.

Neste ponto, no entanto, intervém uma observação do narrador que será determinante no conteúdo alegórico da conversa dos bois. Diz ele:

Todavia, ninguém boi tem culpa de tanta má-sorte, e lá vai ele tirando, afrontado pela soalheira, com o frontispício abaixado, meio guilhotinado pela canga-de-cabeçada, gangorrando no cós da brocha 
de couro retorcido, que lhe corta em duas a barbela; pesando dequina contra as mossas e os dentes dos canzis biselados; batendo os vazios; arfando ao ritmo do costelame, que se abre e fecha como um fole; e com o focinho, glabro, largo e engraxado, vazando baba e pingando gotas de suor (S, p.330).

De chofre, o leitor é jogado de dentro da consciência do boi para seu exterior. O mesmo efeito que o calor exercera anteriormente - o de clivagem na consciência do boi - agora é posto em relevo em sua relação com o próprio carro-de-boi, trazendo consigo a mesma dicotomia entre prazer/desprazer. A ressalva feita pelo narrador ao início do trecho, não obstante, joga as consequências desta dicotomia para outro nível de reflexão. A oposição entre natureza e consciência, com a descrição de todo o aparato do carro-de-boi constringindo o animal, surge agora como um outro com força impessoal. Esta nova oposição entre carro-de-boi e animal, mediada pelo desprazer, abre o espaço para a alegorização de seu pensamento: "Nós somos bois... bois-de-carro... Os outros que vêm em manadas, para ficarem um tempo-das-águas pastando na invernada, sem trabalhar, só vivendo e pastando, e vão-se embora para deixar lugar aos novos que chegam magros, esses todos não são como nós..." (S, p.330-331, grifos meus).

Perceba-se como a descida a níveis mais fundos da consciência animal começa a gerar um senso de causalidade que é diferente do início da novela. Toda a narrativa, até então, seguira a estrutura do causo, com sua causalidade solta e o compromisso com a extração de um fato excepcional. Mas, à medida que a novela se estrutura em novas bases, a casualidade dá lugar à necessidade: não é qualquer conversa em que os bois se engajam, mas sim sobre este outro que é o trabalho a que são submetidos. O significado deste outro, como se vê no desenvolvimento acima, configura-se como tal 
porque é algo que se opõe à vontade do boi. Mas ao contrário do calor - ou da natureza, como passaremos a mencionar este primeiro nível de outridão - o carro-deboi, com suas amarras, cintas e freios, necessariamente insere o elemento humano na reflexão bovina. Isto é, o pensamento sobre o carro divide novamente o raciocínio animal; mas se antes a dicotomia entre prazer/desprazer ligada ao outro da natureza levava à ação do boi evitando o calor, por exemplo, e às consequências que disto poderiam decorrer - os perigos da sombra na mata -, o outro do carro inevitavelmente constrói o espaço para um pensamento impessoal.

Isto porque, ao contrário do calor, o boi é constrangido por uma necessidade que lhe é absolutamente estranha: o porquê de estar amarrado àquele aparato. A impessoalidade desta constrição constrói o lugar para o pensamento animal figurar como alegoria do trabalho, uma vez que o boi é levado a pensar em separações entre categorias de bois - de engorda, de carro - que nada têm a ver com sua própria vontade. Chega-se assim à situação que é essencial à estrutura da novela, que é a da necessidade da intervenção do homem como outro estranho para que os bois ganhem consciência de si e possam pensar sobre seu próprio papel no trabalho. A situação é peculiar porque o desígnio inicial, na forma causo, era demonstrar que animais conversavam. Mas a conversa só é encetada pela introdução do elemento do trabalho que, mantendo-se, aos olhos de boi, como elemento obscuro, acaba virando alegoria do próprio pensamento humano.

Em termos mais claros, a constituição deste outro do trabalho como elemento opaco ao pensamento animal o joga necessariamente no registro da alegoria; a saber, uma voz dentro da narrativa que versa sobre o trabalho e a racionalidade a ele ligada. No meio desta alegoria, está o outro 'misterioso', que é o próprio homem, e que é perscrutado pelo pensamento animal, que tenta compreender seu papel nesta atividade 
estranha que é o trabalho. A configuração desta estrutura alegórica é muito clara em seu início, quando as perguntas sobre os tipos de bois e o homem são feitas:

- Eles não sabem que são bois... - apóia enfim Brabagato, acenando a Capitão com um esticão da orelha esquerda. - Há também o homem... / - É, tem o homem-do-pau-comprido-com-o-marimbondona-ponta... - ajunta Dançador, que vem lerdo, mole-mole, negando o corpo. - O homem me chifrou agora mesmo com o pau... / - $O$ homem é um bicho esmoçado, que não devia haver. Nem convém espiar muito para o homem. É o único vulto que faz ficar zonzo, de se olhar muito. É comprido demais, para cima, e não cabe todo de uma vez, dentro dos olhos da gente. (S, p.331, segundo grifo no original, demais grifos meus)

A caracterização do homem que toca o carro-de-boi com o recurso a uma descrição que é extremamente adjetivante, mas por ser tão literal não o é exatamente, demonstra o ponto acima: a descrição do homem e sua atividade como algo estranho à lógica bovina gera um ponto de vista no qual o trabalho é visto como algo alheio e, portanto, algo que pode se opor ao boi como a natureza o faz. Não há, portanto, da perspectiva animal, algo que medeie a relação de trabalho - como, por exemplo, o entendimento do porquê se necessita aferroar o boi para que ele mantenha seu passo. E é precisamente esta falta de mediação que alavanca o raciocínio bovino ao pensamento alegórico.

Torna-se claro, neste ponto, que o autor vislumbrava uma alegoria que, contrapondo o pensamento 'intuitivo' do boi ao 'racional' do homem, figurasse na novela. A questão que se põe, no entanto, é menos sobre o uso da alegoria e mais como ela precisa figurar no texto para não comprometer a posição do narrador. Se a alegoria aparecesse ex machina, ter-se-ia a noção de que quem comanda a ficção é de fato o bacharel e todo o sentido de necessidade atribuído ao pensamento animal seria 
perdido. A construção da alegoria, como de fato se dá no texto, não só sustenta a hipótese de que o estatuto da ficção continua em disputa entre o capiau e o bacharel, mas também abre espaço para que, desta disputa, algo a mais apareça como resultado da própria complexidade do arranjo narrativo.

Noutras palavras, foi necessária toda a preparação de um ponto de vista minimamente objetivo - isto é, alheio à disputa entre caipira e erudito - para que a alegoria do pensamento racional fosse colocada na boca dos bois como estranhamento ao trabalho e consequentemente estranhamento ao modo como humanos medeiam suas relações, ou, nas palavras do boi, um animal que carrega um vulto que gera vertigem.

Deste ponto se percebe a importância de todo o malabarismo inicial da novela; da passagem do ponto de vista para um campo de mediações entre a irara e Timborna. Trata-se no fundo da constituição de uma perspectiva que habita entre o animal e o humano, e por isso está ao mesmo tempo dentro e fora do universo de mediações humanas. Por estar dentro, sabe-se o que ocorre ao fundo do pensamento bovino: estes são usados como força de tração do carro-de-boi. Por estar fora, no entanto, esta própria atividade - banal do ponto de vista sertanejo e, pode-se dizer, humano - causa estranhamento porque levemente deslocada.

A falta de mediação da alegoria, figurada por exemplo na descrição do carreiro como homem-do-pau-comprido-com-o-marimbondo-na-ponta, acaba criando um vínculo negativo com o universo humano, que é: por que o homem raciocina e, em última instância, trabalha? Sob o tom desta pergunta que a alegoria animal se desenvolve: “ - É porque temos de viver perto do homem, temos de trabalhar... Como os homens... por que é que tivemos de aprender a pensar?..." (S, p.334). É também nesta chave que a alegoria central da novela é construída: a do boi Rodapião, que 
mimetizou o pensamento racional humano (e, bom notar, o próprio calculismo capitalista) ao ponto de se arriscar numa ribanceira para encontrar o melhor pasto. Boi Rodapião rola morro abaixo e morre, e este é o fim do causo contado pelo boi Brilhante. A estória, claro, tem fundo moral e denuncia os perigos do pensamento racional, por isso mesmo se constitui como alegoria. Mas há nela um ponto de contato e outro de descontinuidade que impedem que a alegoria seja circunscrita no registro da fábula. O ponto de descontinuidade é aquele já descrito: o estranhamento ao trabalho e a opacidade dos fins humanos ao pensamento racional. O pensamento bovino se fecha como alegoria mercê deste corte: incapaz de tecer esta mediação, o pensamento se fecha sobre um ensinamento moral, que é o de que bois não devem raciocinar como homens. Este ponto de descontinuidade no entanto impede a entrada na chave da fábula porque, do ponto de vista dos bois, não há um narrador que teça as consequências do pensamento perigoso a um círculo mais amplo de moralidade, que é exatamente o que faz o narrador da fábula ao suspender o contato com este círculo para, ao fim, usar a alegoria como forma de remeter-se a ele.

Outro aspecto que impede a inscrição da alegoria na fábula - este mais decisivo e ponto de continuidade com o cenário que ensejou a alegoria bovina - é o que acontece na trama ao fundo da conversa entre os bois. Os fins para o pensamento racional, inacessível aos animais, vão sendo tecidos em paralelo com o drama humano que se configura entre Tiãozinho e o carreiro Agenor. Se a alegoria bovina supõe uma estranha moralidade antirracional, abstratamente levantada e logo esvanecida, o tecido de relações entre Tiãozinho e Agenor, atadas num emaranhado complexo, dificulta ainda mais a apreensão imediata da alegoria bovina em chave fabulesca. Somente a partir do desenvolvimento desta trama em paralelo é que se é possível expandir a 
alegoria animal; esta expansão, no entanto, não se dá em chave moral, mas é também mediada pelo mundo do trabalho, como veremos.

Da mesma forma que a função narrativo-descritiva apresentou os bois logo no início do causo, quando a palavra fora passada à irara, também os humanos são postos em cena via pura exposição:

Como aquele trecho da estrada fosse largo e nivelado, todos iam descuidosos, em sóbria satisfação: Agenor Soronho chupando o cigarro de palha; o carro sem petulância, arengando; a poeira dançando no ar, entre as patas dos bois, entre as rodas do carro e em volta altura e da feiúra do Soronho; e os oito bovinos, sempre abanando as caudas para espantar a mosquitada, cabeceantes, remoendo e tresmoendo o capim comido de-manhã./ Só Tiãozinho era quem ia triste. Puxando a vanguarda, fungando o fio duplo que lhe escorria das narinas, e dando a direção e tenteando os bois. / $E$, por tudo assim sem história, caminharam um quilômetro ou mais (S, p.329, grifo meu).

O narrador não poderia ser mais explícito quanto à casualidade da cena: apenas um carro de boi, com um carreiro feio e um menino triste puxando os bois à sua frente. Nada nos é apresentado sobre os dois neste ponto, e certamente não será o narrador que se encarregará deste papel mais à frente. Como vimos, a descrição da cena faznos entender como se dá a entrada na consciência dos bois: da mera exposição passase à compreensão do desconforto dos bois com o calor, o efeito disto na dicotomia prazer/desprazer, o estranhamento ao trabalho e, por fim, a alegoria do pensamento bovino sobre a racionalidade. A engenhosidade na construção do texto, no entanto, 
reside no papel verdadeiramente ambíguo que o narrador passa a exercer, sustentando de um lado a conversa entre os bois e do outro a continuidade da cena, na qual reside a ação humana.

Esta ação e seus meandros são obscuros por enquanto, pois se as vê de duas perspectivas: o pensamento alegórico dos bois, incapazes de entender a finalidade do trabalho; e o compromisso expositivo do narrador, que, como já se pode inferir, não tem jurisdição sobre as subjetividades em cena. Tal qual a irarinha que acompanha a ação, o narrador só tem acesso às personagens à medida que a própria cena os afeta. Esta posição do narrador, entre os homens e animais, e com compromisso apenas descritivo, possibilita que seus movimentos subjetivos se deem precisamente no lugar de encontro entre bois e homens: mais ainda, permite que o ponto obscuro da mediação entre ambas as partes, se mostre através do movimento da cena:

- Mas eu já vi o homem-do-pau-comprido correr de uma vaca... De uma vaca. Eu vi./ - Quieto, Buscapé!... Sossega, meu boizinho bom... - clama o menino guia./ Não é à toa que Buscapé é um boi china, espantadiço e pois pernalongo, que avança distanciando muito as patas e costuma relar com os cascos brutos os calcanhares do guia. Mais ao jeito que ele é mogão e mal-armado, que, se tivesse bons estrepes, na parelha da testa um perigo seria./ Mas Agenor Soronho estranhou qualquer lance: - Vigia aí, Tiãozinho! Vi um bicho raboso mexer no matinho... (S, p.331, grifo no original).

O movimento do carro, a maneira como ele afeta bois e homens, abre lentamente o escopo da descrição para o ponto em que é possível passar da consciência dos animais à voz dos humanos via aquilo que os conecta. Enquanto a divagação bovina prossegue em paralelo, a descrição do movimento do carro-de-boi abre pouco a pouco o ponto cego à alegoria animal, que é precisamente esta mediação: 
Acolá, longe adiante, onde as árvores dos dois lados se encontram e encartucham e o caminho se fecha aos olhos da gente, apontaram de repente uns cavaleiros. Vêm chegando. Para que eles possam passar, mesmo tendo de contornar o barranco, Tiãozinho detém os bois./ Boas tarde, seu Agenor! Que é que vão carregando?/ - Umas rapadurinhas pretas, mais um defunto... É o pai do meu guia, que morreu p'r'amanhecer hoje... (S, p.332, grifo meu).

Onde a estrada afunila e dois carros dão de encontro, a própria descrição da cena enseja a explicação da finalidade da viagem. Esta finalidade - ou a abertura dos desígnios humanos - é mostrado ao leitor e ao narrador ao mesmo tempo. Mas, como também ocorreu aos bois, a abertura da voz humana é uma porta à caracterização de seus conteúdos subjetivos. A descrição passa portanto de um impressionismo inicial Agenor Soronho é um homem feio, Tiãozinho um menino triste - a um mergulho um pouco mais fundo no senso de necessidade que guia esta descrição.

Vê-se portanto que o narrador postado num ponto de vista descritivo, acompanhando a cena, permite que a atividade do carro-de-boi - entendido em seu sentido amplo como o porquê da viagem, seu funcionamento e relação com os bois, os encontros com demais carros - encete um duplo movimento. Da parte animal, a formação da alegoria, um pensamento circular pois assentado sobre um ponto cego (o trabalho humano); da parte dos homens, uma espiral que desce da aparência aos motivos mais íntimos de suas subjetividades. Este segundo movimento, como se verá, ao mesmo tempo em que não é uma lógica autocontida como a dos animais, acaba por jogar luz sobre o próprio ponto cego do pensamento bovino e promover a identificação entre homens e animais.

Como último exemplo, vejamos como este tripé narrador-descritivo, homens e bois se articula para a descida nos motivos humanos da estória. "O sol agora está dois 
degraus mais alto. A poeira deixou de ser vermelha: é parda, parecendo cinza fina. Estão num baixadão de campo, de semi-arbustos, flechinha e capim-lanceta, todo encalombado de surujes de cupins" (S, p.336). A descrição narra o movimento do carro e do dia, e o recrudescimento do calor. Novamente o carro cruza com outro no caminho inverso, e a descrição foca precisamente no que aquele carro carrega e os efeitos disto nos bois: "Vem a voz de outro carreiro, gritando. Fazem a volta, acolá, outras juntas: seis parelhas, puxando um carretão, que arrasta imenso toro acorrentado" (Idem, ibidem, grifo meu). O cruzamento dos carros sustenta a interação de todos neles envolvidos, animais e homens: "Tiãozinho sorri para o menino-guia. Soronho saúda os carreiros. E os bois de cá espiam os bois do carretão: com outros, mal conhecidos: Tinhorão, Marechal, Cantagalo e Murici. Também deitam olhares, mas vão afanados, que o peso é pesado" (Idem, Ibidem, grifo meu).

Note-se como a atividade laboral vai se constituindo com mediador entre homens e animais, ou seja, como atividade que carrega um sentido para esta interação e para a disposição tanto dos bois quanto dos homens. Neste momento, no entanto, esta finalidade é ainda obscura tanto ao leitor quanto aos bois, mas à medida em que o trabalho toca os humanos e testa sua reação, é possível ao narrador o deslizamento progressivo em direção ao esclarecimento dos traços do trabalho, sua finalidade e especificidade.

O outro carro passa e o nosso carro agora range com mais força. $\mathrm{O}$ barulho mais um dado da função descritiva - demanda uma ação de Tiãozinho: “- Esperta, boi!...” (S, p.336). O mesmo barulho, no entanto, afeta o carreiro, irritando-o. E é através desta afecção que o narrador pode adentrar um nível mais profundo da espiral humana: 
- Tu Tião, diabo! Tu apertou demais o cocão!... Não vê que a gente carreando defunto-morto, com essa cantoria, até Deus castiga, siô?!... Não vê que é teu pai, demoninho?!... Fasta! Fasta, Canindé!... Ôa!... Ô-ôa!... Anda, fica novo, bocó-sem-sorte, cara de pari sem peixe! Vai botar azeite no chumaço, que senão agorinha mesmo pega fogo no eixo, pega fogo em tudo, com o diabo p'r'ajudar!... (Idem, Ibidem, grifos meus).

A irritação do carreiro e a tensão no carro abrem uma porta ao narrador, pois se trata de um fato objetivo: alguém preparou o veículo de modo que as rodas rangessem demais e pudessem pegar fogo. Através deste fato, o narrador pode adentrar a subjetividade de Tiãozinho e desvendar mais sobre a relação dele com Soronho:

Tiãozinho veio no grito, mas se mexendo encolhido, com medo de que o homem desse nele com a vara-de-ferrão. Falta de justiça, ruindade só. Foi o carreiro mesmo quem apertou a chaveta da cantadeira, hoje cedo; e até estava enjerizado, na hora, falando que Tiãozinho era um preguiçoso, que não prestava nem para ajeitar o carro nem para encangar os bois (Idem, p.337, grifos meus).

Esta construção é notável pois determina a diferença entre a construção da alegoria no pensamento bovino e a constituição do universo humano como passível de expansão e desvelamento intrínseco de significado. Assim como os bois, Tiãozinho age de acordo com o que a situação dele demanda, e como os bois ele teme a consequência de sua inação - a ferroada com a vara. Mas ao contrário dos bois, a constrição advinda do carro e do carreiro não é vista como um outro opaco: Tiãozinho sabe que a culpa não é dele, que quem preparou o carro foi o próprio Agenor. Disto decorre que seu pensamento não se forma como alegoria, mas extrapola a dicotomia entre prazer/desprazer como raciocínio baseado em uma noção vaga de justiça e injustiça. Mais do que isto, a Tiãozinho é acessível a lembrança do que disse Soronho: 
de que o menino não presta ao trabalho, não tem disciplina e habilidade para ajeitar o carro e os bois sozinho.

A abertura do universo do trabalho como um universo percebido como moral é de fundamental importância para o esquadrinhamento da relação entre Tiãozinho e Agenor. Isto porque, com este elemento moral, tem-se à vista algo que aos bois era impossível ver: qual é o teor da dependência entre ambos e, consequentemente, como esta dependência molda sua relação de trabalho. Neste ponto, o narrador está a um passo de ter livre acesso à consciência de Tiãozinho, da mesma forma como fez com os bois quando estes foram confrontados pelo trabalho. Mas, uma vez acessado o conteúdo da relação entre o menino e o homem, ao narrador será possível sair do círculo fechado do pensamento bovino e reconstruir o campo do trabalho que medeia a todos nesta novela.

Antes de configurar este passo, que mudará os rumos da novela, é conveniente, a título de esclarecimento e recapitulação, demonstrar graficamente o esquema narrativo que até então se tentou descrever:

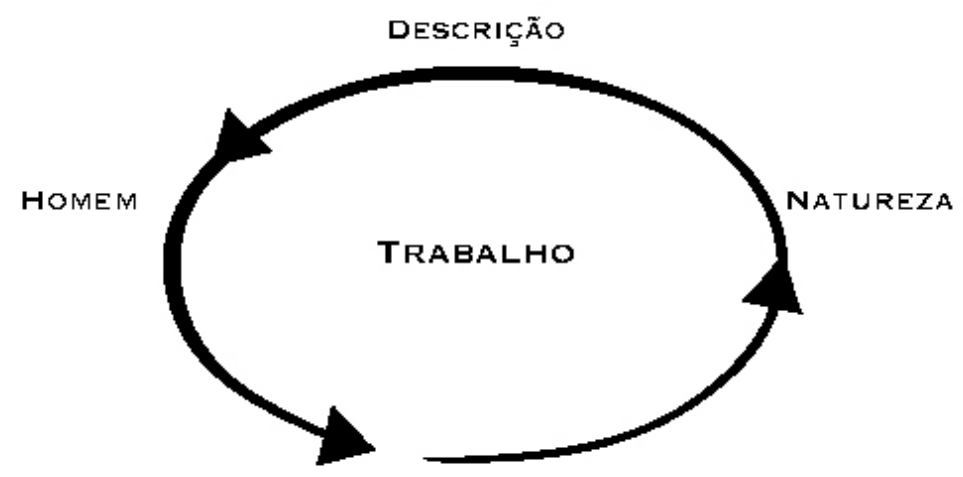

ALEGORIA 
O gráfico serve à demonstração da estrutura inicial do causo, isto é, à maneira como a conversa de bois tem lugar. Esta estrutura, no entanto, circula em torna do trabalho de modo a expô-lo como elemento mediador e como real ponto de interesse da narrativa: mais do que isto, o compromisso com a descrição e com os efeitos dela nos bois gera uma incompletude no círculo do pensamento alegórico, pois aponta para o elemento humano como ponto opaco.

Veja-se que a novela se constrói de modo a fazer todos os elementos acima expostos se relacionarem. Desta forma, pode-se mostrar como os bois relacionam-se com os homens através do campo do trabalho e formam a alegoria, que versa sobre a relação prazer/desprazer (natureza) de modo a remeter novamente ao campo do trabalho. O círculo não se fecha, no entanto, por dois motivos: a alegoria corre em paralelo à dinâmica humana, esperando pelo momento em que o mundo do trabalho se ilumine e promova a identificação entre homens e bois, que só virá ao final da novela. Por outro lado, a ação do narrador sobre os homens se conduz em forma de espiral, preenchendo o campo do trabalho ao mesmo tempo em que escapa ao círculo fechado que é propriamente a atividade do carro-de-boi. Este esquema serve somente como demonstração da estrutura que rege a narrativa do momento em que a palavra é passada à irara - e portanto fica no meio do caminho entre a fala humana e a fala dos animais - até o momento em que todo o drama humano da relação entre Agenor Soronho e Tiãozinho se desvela. O acesso a esta relação, como se disse, teve de passar por todas estas etapas de mediação: a saber, o narrador não a adentrou, ou simplesmente não podia adentrá-la logo de cara, pois ele também estava totalmente imerso na situação da cena. É somente à medida em que o próprio mundo do trabalho interfere nesta relação que é possível acessá-la. Mas uma vez que esta porta é aberta, o mundo do trabalho, que desde o começo mostrou-se como representação opaca e 
fechada sobre a cena do carro-de-boi, acaba por caracterizar a mediação que oferece. E uma vez que a mediação se mostra como tal, a ponte entre a alegoria e o pensamento humano, que promove sua identificação, pode se realizar.

O último movimento da estrutura descrita acima se dá quando Tiãozinho azeita as rodas do carro enquanto o sol quente castiga Agenor. O carreiro mais uma vez reclama da ineficiência do menino, mas desta vez deixando muito claro que sua posição de autoridade tem a ver com a morte do pai de Tiãozinho:

- Que martírio!... De vez que não acaba mais com isso, ou tu pensa que os outros vão ficar no arraial com o cemitério aberto, esperando a gente?!.../ - Já vou, seu Soronho... Já vai.../ - É, nheinhein?!... Ai, que sina, esta minha, trabalhando em sol e chuva, e inda tendo de agüentar este mamão-macho sem preceito!... Tu fala macio, mas p'ra trabalhar comigo tu não presta... Mais em antes eu queria um rapazinho carapaçudo e arapuado, que fosse malcriado mas com sustância que nem eu, p'ra trabucar... Que me importa, se a gente chega de noite no arraial?! O pai não é meu, não... O pai é seu mesmo... Só que tu não tem aquela-coisa na cara... Mas, agora, tu vai ver... Acabou-se a boa vida... Acabou-se o pagode!... (S, p.338, grifos meus).

A finalidade da viagem é finalmente desvelada bem como todo o universo de relações em que nexos familiares e de trabalho se misturam. Torna-se claro que a ascendência que Agenor exerce sobre Tiãozinho vincula-se à morte do pai; isto é, que seu autoritarismo revela a fragilidade financeira e familiar a que Tiãozinho está sujeito.

A partir do acesso a este conteúdo, quando a autoridade de Soronho não é mais obscura e se a pode entender num contexto específico, a narrativa muda de 
constituição. Deste ponto adiante, o narrador tem total acesso à subjetividade do menino, à qual se pode recorrer para a figuração desta posição de dependência. Dizse, portanto, que o narrador deixa seu posto meramente descritivo para um novo tipo de paralelismo. Os pensamentos dos bois continuam funcionando em sua circularidade, permanecendo no mesmo eixo alegórico. São as reflexões do menino, abastecidas pela melancolia da morte do pai e da crueldade de Soronho, que, ao descer cada vez mais fundo em direção à natureza desta dependência, forja um ponto de contato com o pensamento bovino. Vejamos como isto acontece.

Acompanhando este novo eixo narrativo, a descrição da cena passa a se confundir com os pensamentos de Tiãozinho, que a princípio reconstroem seu cenário familiar: "Chora-não-chora, Tiãozinho retoma seu posto. 'O pai não é meu, não... O pai é seu mesmo...' Decerto. Ele bem que sabe, não precisa de dizer. É o seu pai quem está ali, morto, jogado para cima das rapaduras... Deixou de sofrer... Cego e entrevado, já de anos, no jirau” (S, p.338). O narrador, já dentro da mente de Tiãozinho, continua:

\begin{abstract}
Ah, da mãe não gostava!... Era nova e bonita, mas antes não fosse... Mãe da gente devia de ser velha, rezando e sendo séria, de outro jeito... Que não tivesse mexida com outro homem nenhum... Como é que ele ia poder gostar direito da mãe?... Ela deixava até que o Agenor carreiro mandasse nele, xingasse, tomasse conta, batesse... Mandava que obedecesse ao Soronho, porque o homem era quem estava sustentando a família toda (Idem, p.339, grifo meu).
\end{abstract}

A estrutura de seu pensamento é similar à dos bois, significando que a cena transcorre enquanto suas ideias percorrem um caminho de associações engatilhadas pelo desprazer no trabalho. Mas ao contrário dos bois, o desprazer não gera o pensamento 
alegórico: ele segue um caminho muito específico de reconhecimento de seu Soronho como a fonte de autoridade que o condiciona àquela situação de dependência:

Mas o carreiro não gostava de Tiãozinho... E era melhor, mesmo, porque ele também tinha ojeriza daquele capeta!... Ruço!... Entrão!... Malvado!... O demônio devia de ser assim, sem tirar nem pôr... Vivia dentro da cafua... Só não embocava era no quartinho escuro, onde o pai ficava gemendo; mas não gemia enquanto o Soronho estava lá, sempre perto da mãe, cochichando os dois, fazendo dengos... Que ódio!... (S, p.339)

A caracterização do mal neste contexto é muito diferente da moralização extraída do pensamento alegórico. Isto porque, embora correndo livre a esta altura e imbricado à voz do narrador, o pensamento de Tiãozinho constrói seu próprio lastro e figura uma situação em que o desprazer em relação ao trabalho não se constitui abstratamente, mas identifica aquele que o explora. Este novo registro em que a novela funciona fica claro quando, agora sob a perspectiva de Tiãozinho, a mediação do trabalho não mais aparece como um signo opaco de dominação, uma constrição que leva os bois ao devaneio sobre sua condição de bois de carro. Ela tem cara, contexto e atua em situações específicas.

Neste ponto, o simples registro dos acontecimentos - a aleatoriedade do causo de um carro-de-bois em que os animais conversam - é inteiramente revertida por um senso de necessidade de um drama humano. Em outras palavras, uma história qualquer e extraordinária dá lugar à história de Tiãozinho, seu pai morto e sua dupla dependência face a Soronho: financeira e familiar. Assim, à medida que os pensamentos de Tiãozinho se desenvolvem, eles se aproximam do pensamento dos bois não por engenho do narrador, mas porque, ao descer a espiral de sua 
dependência, o menino se aproxima de uma pura dominação que, formalmente, se assemelha ao uso dos animais no trabalho.

A diferença é nítida quando se atenta, por exemplo, às ações de seu Soronho em sua função de carreiro como parte do aparato opaco do trabalho - o homem-dopau-comprido-com-o-marimbondo-na-ponta - e quando as mesmas ações são vistas agora da perspectiva de Tiãozinho. Quando os bois se agitam e o menino tem que dar conta da situação (exercendo portanto sua função como menino-guia), ele pensa:

Também, quem tem a culpa d'eles ficarem assim desinquietos é o carreiro, que vem picando os bois, à toa, à toa, sem precisão. É mau mesmo. 'Mas, agora, tu vai ver!... Acabou-se a boa vida... Acabou-se o pagode!'... P'ra que falar isso?!... Seu Soronho sempre não xingou, não bateu, de cabresto, de vara-de-marmelo, de pau?!... E sem ter caso para mão brava, nem hora disso, pelo que ele lidava direito, o dia inteiro, capinando, tirando leite, buscando os bois no pasto, guiando, tudo... Mas Tiãozinho espera... Há-de chegar o dia!... Quando crescer, quando ficar homem, vai ensinar seu Agenor Soronho... (S, p.340-341, grifos meus).

Tanto a maldade de Soronho quanto o desejo de Tiãozinho ganham contornos mais definidos, e a memória, como acontece em outros escritos de Sagarana, passa a exercer o papel de dobradiça que abre a perspectiva do narrador a contextos sociais mais amplos. O significante opaco do trabalho desaparece e dá lugar a uma situação muito bem definida. Mesmo com Tiãozinho cuidando de toda a lida que sustenta a própria possibilidade de trabalho de Agenor, este ainda insiste em aguçar a situação de dominação. O devaneio de Tiãozinho - sobre quando crescer, quando puder confrontar pessoalmente seu Agenor num embate de potência contra potência começa a trazer a proscênio os traços principais desta situação de trabalho. O carrode-boi, o trabalho como guia sob sol quente, se misturam a todas as outras atividades 
em que Tiãozinho se envolve enquanto trabalhador braçal. Toda a relação entre Agenor e o menino é, portanto, mediada pelo trabalho. Mas este trabalho carrega exatamente a peculiaridade de ser mediado apenas por um fator: Agenor, por fazer coincidir a função de pai e empregador, forja um tipo de dependência na qual o imperativo do trabalho parece ser absolutamente não-mediado; ou seja, chama para si as feições de um autoritarismo total sobre o corpo e a mente de Tiãozinho ${ }^{49}$. É por este motivo que a língua do trabalho, nos devaneios do menino, pode aparecer como um embate entre impotência e potência. Esta língua esconde a relação mediação-nãomediada, mas coloca em primeiro plano um aspecto fundamental desta relação de trabalho, que é o embate entre corpos.

A figuração da dupla dependência de Tiãozinho revela um aspecto da dominação laboral que, como diria Marx, é muscular em seu limite; não porque todo trabalho revela um gasto fisiológico, como algumas interpretações de Marx levam a $\operatorname{crer}^{50}$, mas porque o trabalho no capitalismo depende de uma intrincada relação entre mediação e produção, em que a abstração do tempo de trabalho caminha ao lado da alienação em relação aos meios de produção e do imperativo de acumulação. Quando a mediação falha, esta negação básica do capital é exposta: a negação ao acesso aos

\footnotetext{
${ }^{49} \mathrm{Na}$ crítica de Rosa é comum se chamar a atenção à ausência da figura paterna como traço marcante em sua obra. Vemos isto claramente em Grande sertão: veredas, onde a trajetória de Riobaldo é marcada pela ausência de filiação paterna. O mesmo poderia ser dito de "A terceira margem do rio", nas Primeiras estórias. Trata-se de um veio de análise importante, e não se descarta a ajuda da psicanálise para decifrá-lo. A psicanálise ajuda a entender a relação entre o 'nome-do-pai', como escreveu Lacan, e a lei; relação tão clara em Guimarães Rosa. Faz-se somente a ressalva que as leituras devem ser remetidas ao contexto sertanejo, no qual a figura do pai poderia servir, como autoridade investida pelo contexto patriarcal, como entreposto entre esferas de dominação. É basicamente o que se observa em "Conversa de bois": fosse a função paterna efetivamente ligada ao "nome-do-pai', o caráter de dominação de Agenor sobre Tiãozinho teria outra feição, pois entre a autoridade e o trabalho se colocaria a lei. Mas esta não nos interessa, uma vez que o texto nos apresenta, sem nenhum acaso, uma situação que possibilita a apresentação do trabalho como uma ascendência do carreiro sobre todas as esferas da vida de Tiãozinho.

${ }^{50}$ Ver o capítulo "Abstração real e contradição: sobre o trabalho abstrato e o valor" em Sentido da dialética, por Ruy Fausto, 2015.
} 
meios de produção e a incidência de uma necessidade absoluta de trabalho, que se revela exploração nua. A dupla dependência de Agenor sobre Tiãozinho expõe esta falha, na medida em que a ausência paterna possibilita que as atividades comerciais do primeiro tenham total ascendência sobre o trabalho do menino, e somente por isto a fronteira da exploração do trabalho é o próprio limite da exaustão corporal ${ }^{51}$. Noutras palavras, novamente o espaço social do sertão se configura como um lócus em que o imperativo do trabalho se liga à circulação de mercadorias, com a peculiaridade de que sua não-mediação abstrata (no caso, a pura dominação patriarcal de Agenor) pode levar a exploração deste trabalho aos limites do corpo.

Em trabalho recente sobre Vidas Secas, Ana Paula Pacheco chamou atenção à fantasmagoria do trabalho no livro; a saber, relações de trabalho que "aparecem e desaparecem", criando algo como uma "invisibilidade social do trabalho" (PACHECO, 2015, p.38). A crítica ressalta o aspecto do livro que talvez tenha dificultado leituras que visassem especificamente as relações de trabalho nele presentes: sua fantasmagoria o torna invisível e sua precariedade e miséria se confundem com a miséria da própria família de retirantes. Isto pode ter alavancado o que a crítica chamou de leituras humanistas da obra, como a que enxerga a proximidade da família da situação animal como uma "reserva ética" contra a reificação absoluta do trabalho ${ }^{52}$. Contra esta leitura, a Pacheco afirma: "O trabalho dos retirantes - e o trabalho da caça ao trabalho - quase não tem contornos, por ser quase tudo" (Idem, Ibidem, grifo no original). Em nota, ela caracteriza este trabalho como 'trabalho total': "a saber, a vida, ou a pessoa inteira, transformam-se em trabalho" (Idem, Ibidem). Em outras palavras: um trabalho sem reservas não tem

\footnotetext{
${ }^{51}$ Não à toa, portanto, Tiãozinho se lembra da história do menino-guia Didico, que morreu no ato de guiar um carro-de-bois sozinho.

${ }^{52}$ Ver a nota 10 do artigo citado, "O vaqueiro e o procurador dos pobres: Vidas Secas".
} 
contornos por se misturar com a própria vida. Menos em um sentido humanista, temse uma visão não-alegórica do trabalho, no qual a confusão com a totalidade da vida do trabalhador é o que caracteriza o tipo de exploração.

A questão envolvendo trabalho humano e trabalho animal, em "Conversa de bois", poderia alavancar o mesmo tipo de análise que Pacheco combate, na qual se inverteria o eixo que aqui se procura seguir: a aproximação de Tiãozinho da lógica dos bois no fundo seria um trunfo, uma reserva ética contra a exploração, quando na verdade é o contrário. Esta paulatina aproximação, à medida que o menino é levado à exaustão, força um ponto de convergência em que se perdem os contornos do trabalho. Mas ao contrário de Vidas Secas, aqui ele não se exprime como fantasmagoria, mas como explosão de potência. Ao porquê desta particularidade retornaremos à frente: por ora, vale dizer que o fecho da novela encontra um nexo de coerência com a armação de sua estrutura narrativa, demonstrada acima, na qual o campo do trabalho exerce a mediação entre as várias instâncias da trama que funcionam ao mesmo tempo. Um olhar a este 'trabalho total', portanto, se torna necessário para o desvendamento do desfecho de "Conversa de bois".

$$
* * *
$$

Antes de retornarmos ao cerne da novela, retenhamo-nos ainda um pouco mais sobre a relação de mediação exercida pelo trabalho no capitalismo. Voltamos ao Marx do Capital, mais especificamente aos capítulos vinte quatro e vinte cinco no primeiro volume d'O Capital. Estes capítulos, segundo David Harvey, geram uma quebra nos modos de exposição anteriores, utilizados por Marx. Afirma Harvey, 
eles vão de encontro ao pressuposto central do resto do livro, estabelecido no capítulo 2, em que Marx aceita o mundo teórico de Adam Smith de trocas atomísticas realizadas no mercado; nesse mundo, a liberdade, a igualdade, a propriedade e Bentham reinam de tal modo que todas as trocas de mercadoria ocorrem num ambiente não-coercitivo de instituições liberais em perfeito funcionamento. (HARVEY, 2013,p.277, grifo meu).

O próprio Marx dá conta desta necessidade de regredir à análise histórica para demonstrar como as teorias liberais - muito embora descrevam o funcionamento do capital - falham ao reconhecer sua origem. Ele afirma:

$\mathrm{Na}$ história real, como se sabe, o papel principal [para o desenvolvimento do capital] é desempenhado pela conquista, a subjugação, o assassínio para roubar, em suma, a violência. Já na economia política, tão branda, imperou sempre o idílio. Direito e 'trabalho' foram, desde tempos imemoriais, os únicos meios de enriquecimento [...]. Na realidade, os métodos de acumulação primitiva podem ser qualquer coisa, menos idílicos (MARX, 2013, p.786).

Sabe-se, Marx deseja reconstituir o cenário europeu de constituição do capital, no qual a subversão do antigo direito feudal foi essencial em duas frentes: na concentração de terras e capital e na liberação de mão-de-obra à manufatura. No que diz respeito à mão-de-obra, é importante para Marx atacar a premissa liberal de liberdade em sua venda: Marx não desconsidera que, em certa medida, o proletário é legalmente livre para trabalhar em qualquer setor da economia que necessite de seu trabalho. Mas o ponto importante - e o que caracteriza a noção de acumulação primitiva - é a ideia de que esta liberdade só foi constituída a partir do rompimento das relações feudais que vinculavam o camponês à terra: este corte, forçosamente violento, gerou uma nova situação jurídica. O camponês perde o amparo das relações 
feudais (que distinguiam claramente um dentro e for jurídico no qual ele se inseria em vínculos de obrigação e proteção como parte do feudo) para uma situação outra, em que a terra passa a não ser mais o lastro jurídico do trabalho, mas sim o próprio corpo físico do trabalhador.

Marx é bem claro quanto a esta necessidade de cesura no trabalho e em suas consequências legais: “A assim chamada acumulação primitiva não é, por conseguinte, mais do que o processo histórico de separação entre produtor e meio de produção" (Idem, Ibidem). O que isto significa para o processo capitalista de acumulação é um pouco mais complicado, no entanto. Para que se estabeleça a mediação entre meios de produção e trabalhador, Marx atenta que

é preciso que duas espécies bem diferentes de possuidores de mercadorias se defrontem e estabeleçam contato; de um lado, possuidores de dinheiro, meios de produção e meios de subsistência, que buscam valorizar a quantia de valor de que dispõem por meio da compra de força de trabalho alheia; de outro, trabalhadores livres, vendedores da própria força de trabalho e, por conseguinte, vendedores de trabalho (MARX, 2013, p.786, grifos meus).

Não cabe aqui explorar todas as consequências desta definição. O que é importante notar é que a constituição do trabalhador como sujeito livre e possuidor de uma mercadoria - sua força de trabalho -, imprescindível para que o capital passe do trabalho aos meios de produção, depende primeiramente que este registro da mercadoria coincida com o próprio corpo do trabalhador. Daí advém a ideia de 'trabalho total': pois, separado de qualquer possibilidade de subsistir sem se inserir no processo de valorização, a relação de troca entre trabalho e salário deve ocorrer neste registro do corpo, não mais sendo mediado pela relação corpo-terra. 
Encontra-se aqui mais uma vez a ideia de continuidade/descontinuidade subsistindo no mesmo local de acumulação, pois que a relação capitalista fundante se dá no vínculo do trabalhador com a mediação não-mediada do trabalho. Este complexo nexo gerará as críticas de Marx aos direitos do cidadão - considerados, por um lado, uma conquista dos trabalhadores contra esta exploração direta sobre o corpo, mas também um construto do capital para que ele mesmo possa exceder os limites que a acumulação primitiva exibe. Mais importante, no entanto, é a desmistificação da outra parte desta relação: aquela que exerce a dominação.

Sua brutalidade, é claro, remete a formas arcaicas de exploração do trabalho. Mas é necessário distingui-la de tais, como o faz Moishe Postone em seu comentário de Marx:

\begin{abstract}
Nos casos de cooperação e manufatura, a apropriação das forças produtivas do trabalho concreto para o capital pode parecer ser uma questão de propriedade e controle, ou seja, uma função da propriedade privada, porque essas forças ainda são constituídas pelo trabalho humano direto na produção $e$, por conseguinte, podem parecer apenas extrinsecamente relacionadas ao capital. A análise de Marx sugere, no entanto, que embora tenha desempenhado um papel central neste processo de alienação na emergência histórica do capitalismo, a propriedade privada não se mantém estruturalmente central com o desenvolvimento da grande indústria (POSTONE, 2014, p.405, grifos meus).
\end{abstract}

O comentário de Postone permite que se coloque em questão o adjetivo 'primitivo' a este caráter da exploração capitalista. Como se vê, ela não se dá fora do capital, mas numa relação de simultâneas exterioridade e interioridade do capital. Isto porque a acumulação primitiva é precisamente o nexo entre a propriedade - os meios de produção, o trabalho - e seu caráter abstrato - a acumulação, o dinheiro. Por este 
motivo é possível estender a noção de acumulação primitiva para além dos momentos de formação do capital e encontrá-la nos momentos em que se luta para a criação de condições para o desenvolvimento propriamente capitalista dos modos de produção, nos quais a alienação do trabalho "é intrínseca ao próprio processo de sua constituição". Postone continua: "na verdade, a condição para sua realização histórica é precisamente o fato de serem constituídas de maneira separada e oposta aos produtores imediatos" (Idem, Ibidem, grifos meus).

Este embate caracteriza o cenário brasileiro após a abolição da escravidão e caracteriza toda a crise acumulativa da Primeira República. A luta para a criação de um modo de produção sistemicamente alienante - e portanto estruturalmente separado dos produtores imediatos - é o que se observará no Brasil após as reformas da década de 1930. Antes disto, a produção gira em torno desta relação ambígua entre propriedade e acumulação e por isso assume a feição de acumulação primitiva: porque o esforço de liberação das amarras do escravismo joga as relações de produção numa relação de conflito constante entre terra e corpo do trabalhador, em que ambos se opõem na constituição da força de trabalho, mas continuam vinculados na produção enquanto função da propriedade fundiária, já que não existe mercado de mão-de-obra.

Deste ângulo é possível entender o comentário de Francisco de Oliveira sobre o período, em que afirma que

O limite da possibilidade de aumento da produtividade numa economia deste tipo é, no máximo, dada pela fase de cooperação; mais além, o aumento da produtividade mesmo em termos físicos esbarra naquilo que Marx chamou de 'transferência da virtualidade técnica do operário para a máquina', pois essa metamorfose, que culmina na subsunção formal do trabalho ao capital em subsunção real, não é possível na ausência de trabalho livre (OLIVEIRA In FAUSTO, 2006, p.442, grifo meu). 
Por isso Oliveira pode afirmar que, na Primeira República, não se produziu acumulação, somente riqueza. Esta busca pela produção de riqueza, num setting de acumulação primitiva, é o que imprime a produção do sertanejo sob o imperativo do 'trabalho total', pois é este semi-campesinato que irá cumprir, "para o nascente modo de produção de mercadorias interno, o papel de acumulação primitiva, que a economia colonial havia desempenhado para o modo de produção de mercadorias externo" (Idem, p.443, grifos no original).

O corpo do trabalhador, neste quadro, se torna a própria arena de disputa de formação do capital: por um lado, ele é premido pelo imperativo de geração de mercadorias e riqueza; por outro, é mantido sob controle do capitalista, pois não há mercado de trabalho formado e, como já se disse, circulação de valor em forma de salários. Daí se compreende o tipo de dependência produzida neste período e que caracteriza propriamente o sertão: uma em que se vincula o corpo do trabalhador e seu trabalho a um estatuto ambíguo com a terra, pois que, seguindo Marx, este se coloca simultaneamente no ponto de corte/separação dos meios de produção e sob o imperativo de produção de mercadorias.

A 'reserva ética' neste panorama de configuração do sujeito de trabalho é portanto inexistente. Sob este tipo de dependência, toda a função subjetiva do trabalhador se dá em função do trabalho: no caso de "Conversa de bois", portanto, o carro-de-boi é mais do que uma alegoria desta situação. Ele é toda a mediação da relação entre o carreiro-comerciante e o menino-guia, porque guiar o carro é sua tarefa diante da ordem de Soronho; a brutalidade de Agenor, por outro lado, é a face desta relação que, ao contrário do que se poderia pensar, abre-a a um contexto mais 
amplo, no qual se vinculam circulação de mercadorias e posse de terras. Por isso o delírio/transe de Tiãozinho se dará na chave da potência e numa intervenção direta sobre a autoridade de Agenor Soronho, pois a autoridade do carreiro é o que segura este arranjo de mediação pelo trabalho total. Mas, como fica claro no texto, a intervenção contra o domínio de Soronho se dará através de seu aparato mediador - o carro de bois e suas ferramentas, os próprios animais - revelando portanto como as revoluções da forma de Rosa se ancoram neste dilema particularmente sertanejo: a pertença dentro e fora, a favor e contra os processos básicos de acumulação nas tentativas de integrar o país sob a indústria.

Neste ponto é importante trazer a bordo a referência ao estudo de Maria Sylvia Franco sobre a sociedade caipira do século $\mathrm{XIX}^{53}$. A tendência à não-mediação de conflitos, para a historiadora, revela em que medida a sociedade brasileira funcionava sob um registro personalista do direito. $\mathrm{O}$ que encontramos já no século $\mathrm{XX}$ é uma perspectiva um pouco diferente: este personalismo não desaparece, como é evidente em Guimarães Rosa. Mas mostra-se transformado por uma mediação mínima que emerge no mundo do trabalho. Por menor que seja, no entanto, esta mínima mediação vira palco para as disputas dentro do coronelismo. A sede de expansão coronelista revela-se assim menos uma persistência do poder privado em meio à modernização e mais o signo de seu pertencimento a um movimento mais amplo da matéria histórica brasileira. A mínima mediação, por outro lado, é também o local do sertanejo nesta grande ciranda: a escolha de perspectiva de Rosa, neste sentido, é também mínima, como a cena que acompanhamos aqui. Mas cabe ao seu desdobramento crítico encontrar nas agitações minimalistas desta cena seus vínculos com este objeto maior, que chamamos de sertão.

\footnotetext{
${ }^{53}$ Ver, de Maria Sylvia Franco, Homens livres na sociedade escravocrata. $4^{\mathrm{a}}$ ed. São Paulo: Fundação Editora da UNESP, 1997.
} 
“ - Vam’bora, lerdeza! Tu é bobo e mole; tu é boi?!...” (S, p.347, grifo meu). As palavras de Agenor Soronho têm um fim - fazer o carro-de-boi repleto de rapaduras, sobre as quais um defunto descansa - chegar ao vilarejo onde o pai de Tiãozinho será enterrado, mas mais importante, onde as rapaduras serão vendidas. A ordem atravessa o carro-de-boi imprimindo sua necessidade - a celeridade - e por meio desta ordem, bois e Tiãozinho se igualam na condição de aparatos que movimentam o carro. A pergunta que iguala o menino aos bois tem um fundo retórico importante: ela é impossível de ser direcionada aos bois, pois destes não se pode extrair uma noção abstrata de eficiência visando um fim. Os bois respondem ao estímulo que gira na chave prazer/desprazer; já Tiãozinho funciona em outro registro. A este é possível uma redução à condição bovina, que no limite significa a ameaça da incidência da pura brutalidade. Mas a autoridade, neste caso, não funciona na mesma matriz dos bois: ela não gera uma mera oposição entre sensações boas e sensações ruins. A autoridade de Soronho atravessa a subjetividade de Tiãozinho, reduzindo-o a aparato do carro ao mesmo tempo em que o vincula ao imperativo comercial.

Esta dupla relação - redução a aparato e vínculo inextrincável à autoridade do carreiro - circunscreve o espaço social que Tiãozinho habita e condiciona seu devaneio. A humanidade de Tiãozinho é portanto definida por aquilo que ele sabe como resto de sua redução a este fim acumulativo e a este espaço, junto ao narrador e em oposição aos bois: ao passar por uma fazenda, que poderia ser uma fazenda qualquer, o narrador afirma: "Estão passando agora em frente à Fazenda do seu 
Gervásio [...]./ A casa está aberta, mas não se vê ninguém. Todos foram ao canavial, pois é o começo do tempo de corte, marcar a cana caiana que vão moer amanhã demanhã" (S, p.341, grifo meu). Note-se que não é um saber constituído, como talvez se esperaria do sujeito burguês engajado na acumulação, calculando os meios necessários para obtenção de lucro. Tiãozinho forma um saber alienado neste sentido de resto: algo que sobra de sua própria exploração, de seu vínculo com Agenor e o carro-de-bois.

É este saber despedaçado que vai escapando da constante redução do menino a aparato acumulativo: a morte do pai, neste sentido, exerce função simbólica primordial, pois aponta precisamente à ausência consumada de qualquer anteparo entre Tião e Agenor. Exercida esta redução sem reservas, sobra somente o vínculo com o carreiro que, por sua condição alienante, não lhe agrega nenhum conteúdo subjetivo: a percepção de que Tiãozinho funciona apenas como roldana laboral é notada através do despedaçamento do mundo do trabalho, no qual se reconhece que há nele um fim, mas cujos objetos e seus usos lhe escapam totalmente:

Tiãozinho atraso o passo, para aproveitar. Mas ainda está triste. Não quer pensar no pai depois - tem medo de pôr a idéia no corpo que vem em-riba da pilha de rapaduras. Só agüenta pensar nele de-emantes, na cafua... Pega a imaginar outras coisas. Fala aos bois, sem precisão: - Buscapé!... Brabagato!... - Depois, faz força para se lembrar dos nomes das vacas todas de seu Major Gervásio: Espadilha... Bolívia... Azeitona... Mexerica é a turina. Porcelana é a toda branca, desmochada. Guiamina é a preta, de cinturão branco no cilhador... (S, p.345, primeiro e terceiro grifos no original, demais grifos meus).

O que sobra desta redução e despedaçamento, no pensamento de Tiãozinho, é a simples adjetivação das vacas do fazendeiro. Vê-se portanto que estes restos apontam 
para os dois vetores de dependência que atuam sobre o menino: por um lado, a autoridade do carreiro; por outro, seu vínculo com a terra onde provavelmente vive como agregado. É precisamente neste espaço do mundo despedaçado que surge a identificação entre os bois e Tiãozinho: pois a espiral que se abre na subjetividade de Tiãozinho - a mesma que caracterizou seu universo familiar e sua relação com Agenor - chega a este espaço de mínima redução em que só é possível a adjetivação de objetos: as vacas são brancas, pretas etc.

É neste lugar que o pensamento dos bois e do menino se tocam: o lugar da simples descrição, adjetivação da ação, em que as coisas não têm nome porque não têm inscrição no mundo humano; isto é, lugar onde falta a consistência do nexo entre atividades, coisas e finalidade, que é dada ao homem via trabalho:

E desde que o carro acaba de virar para trás das rodas a dobra do espigão, até alcançar a chapada de terra vermelha, são trezentos $e$ cinqüenta metros de silêncio, antes de Dançador voltar a cara, espiando, e de Capitão perguntar:/ - Que é que está fazendo o carro?/ - O carro vem andando, sempre atrás de nós./ - Onde está o homemdo-pau-comprido?/ - O homem-do-pau-comprido-com-omarimbondo-na-ponta está trepado no chifre do carro.../ - E o bezerro-de-homem-que-caminha-sempre-na-frente-dos-bois?/ - O bezerro-de-homem-que-caminha-adiante vai caminhando devagar... Ele está babando água dos olhos... (S, p.356-357, grifos meus).

Esta passagem do pensamento bovino ao de Tiãozinho reverte a situação inicial da novela, colocando em xeque a noção de natureza que antes guiava a alegoria bovina. Esta inversão torna-se clara, por exemplo, quando novamente o significante do trabalho vem à tona em seu raciocínio:

- Que é o que está dizendo o boi Dançador?/ - que nós, os bois-decarro, temos de obedecer ao homem, às vezes.../ - O homem não 
sabe./ - O bezerro-de-homem não sabe... O nosso pensamento de bois é grande e quieto... Tem o céu e o canto do carro... O homem caminha por fora. No nosso mato-escuro não há dentro e nem fora... (Idem, p.358, grifos meus).

O saber, fica claro, tem a ver com a finalidade do trabalho e a própria inscrição dos bois nele (por isso o questionamento sobre sua obediência). Pensar dentro e fora, neste caso, é pensar fora deste imperativo opaco: ou seja, o homem pode movimentarse nos meandros do mundo do trabalho, orientando-se por sua finalidade, guiando-se por sua necessidade. Já o bezerro-de-homem não pode, como os bois; não porque ele se aproxima de sua naturalidade, mas porque o mundo do trabalho o comprime em necessidade absoluta, em 'trabalho total', uma redução em que não há dentro e fora, apenas o imperativo.

O transe de Tiãozinho, portanto, coincide com este momento de redução absoluta, momento em que, atravessado pela autoridade de Agenor, ele está inteiramente imerso no ponto escuro do trabalho. Este atravessamento lhe dá o conteúdo - o mundo despedaçado - e a identificação com os bois lhe fornece a ideia de potência vinculada à posse terra. Mais do que indicar uma regressão, trata-se da negação do duplo nexo de dependência que o segura na condição de sertanejo: a noção de potência ligada à posse de terra emerge como imaginário negativo da situação de alienação que desvincula o sertanejo da terra e o submete à exploração não-mediada. Circunscrevendo este duplo nexo, o enfrentamento se dá ante a autoridade de Agenor, o fio que o vincula ao campo de dependência:

- Mhú! Hmoung!... Boi... Bezerro-de-homem... Mas eu sou o boi Capitão!... Moung!... Não há nenhum boi Capitão... Mas, todos os bois... Não há bezerro-de-homem!... Todos... Tudo... Tudo é enorme... Eu sou enorme!... Sou grande e forte... Mais do que seu 
Agenor Soronho!... Posso vingar meu pai... Meu pai era bom. Ele está morto dentro do carro... Seu Agenor é o diabo grande... Bate em todos os meninos do mundo... Mas eu sou enorme... Hmou! Hung! ... Mas, não há Tiãozinho! Sou aquele-que-tem-um-anel-branco-aoredor-das-ventas!... Não, não, sou o bezerro-de-homem!... Sou maior que todos os bois e homens juntos (S, p.359, grifos no original)

A figuração desta potência, adquirida via esta identificação, revela em negativo o laço que constringia Tiãozinho: não só a ideia de ele se tornar um boi, mas o abuso de uma noção de potência absoluta - 'sou maior que todos os bois e homens juntos' - aponta exatamente para a totalização do trabalho e diminuição da subjetividade a resto. Por esta via de negação do resto e positivação de uma potência impossível, Tiãozinho maneja sua identificação com os bois. Não por acaso, o resultado desta identificação é a negação dos últimos restos do mundo do trabalho, os nomes dos bois e sua função: “Não há bois... Tudo... Todos... A noite é enorme... Não há bois-de-carro... Não há mais nenhum boi Namorado..." (Idem, Ibidem). A perda de qualquer lastro com o mundo do trabalho, através deste último momento de negação do resto, é o que permite esta subversão impossível: “Eu, Tiãozinho!... Sou grande, sou dono de muitas terras, com muitos carros de bois, com muitas juntas" (Idem, p.360, grifo meu).

Este impulso, que impele o primeiro tranco que chacoalha o carro, se dá de um lugar inteiramente fora do mundo do trabalho, de onde Tiãozinho pode imaginar a subversão completa de sua situação de dependência e, portanto, afirmar sua condição animal. O segundo tranco, no entanto, revela um aspecto surpreendente; ele se volta para dentro do trabalho novamente, com o papel do menino como guia:

- Namorado, vamos!!!... - Tiãozinho deu um grito e um salto para o lado, e a vara assobiou no ar... E os oito bois das quatro juntas se 
jogaram para diante, de uma vez... E o carro pulou forte, e craquejou, estrambelhado, com um guincho do cocão (S, p.361).

Tiãozinho chama o boi pelo nome, que havia sigo negado momentos atrás, inscrevendo ambos no universo do trabalho novamente. Sua vingança se dá, portanto, de um lugar que é concomitantemente dentro e fora do trabalho. Ou, melhor dizendo, se dá como um movimento de furo de dentro da condição mais íntima do trabalho sertanejo, que irrompe sobre o seu fio condutor - a autoridade de Agenor - negandolhe a finalidade da tarefa do carro-de-boi, que era a chegada à vila com a mercadoria, e mesmo destruindo o próprio aparato que fusionava todos os elementos da trama: o carro-de-boi.

A vingança contra Agenor é uma explosão da tensão construída durante toda a novela. Mas ela não muda nada na condição de Tiãozinho, que após o transe se dá conta do ocorrido e chega a mostrar até arrependimento. Por um lado, mostra-se a impossibilidade que marca a superação pessoal deste tipo de dependência. Por outro, no entanto, revela-se que a tensão buscada pelo texto estava no setting existente, precisamente a mediação da autoridade via o trabalho no carro-de-boi. A excepcionalidade da estória, neste sentido, não recai em Tiãozinho como herói, e menos ainda na pessoalidade do mal, encarnada em Agenor: mas naquilo que irrompe da tensão que se construiu: uma tensão que, não por acaso, acompanha os rangidos do carro-de-boi. É o que mostram os últimos parágrafos da novela:

Chorando outra vez. - 'Coitado do seu Agenor!... Era brabo, mas não era mesmo mau-de-todo, não... Tinha coração bom... Mas não foi por meu querer... Juro, meu Nosso Senhor!...' - Com jeito, seu Quirino! Credo, Nhô Alcides, já tinha outro defunto aqui dentro!... Meu pai! Não tem culpa. Tristeza. Frio. O sol foi s'embora. Mas é preciso ajudar. Estou bem, não tive nada. Negócio urgente de Nhô Alcides. 
Seu Quirino carreia, a cavalo mesmo. Os bois querem caminhar. 'Vamos, Buscapé! Namorado, va-âmos!...' (S, p.362)

A compressão do tempo e das sentenças que passam pela mente de Tiãozinho aponta para a normalidade que se retoma após os eventos. Isto é, Tiãozinho volta a seu lugar e retoma sua função. Com isso, o interesse no causo se esvazia, e a irara Risoleta desvia sua atenção e fecha o texto.

Assim, a estrutura do causo acaba por retornar, afirmando seu interesse pela estória excepcional. Mas o sumo formal que se extrai de "Conversa de bois" é totalmente diverso daquele intendido pelas duas personagens iniciais. Não se trata de uma prova de que animais falam: o que buscamos mostrar é que o aparato sobre o qual se medeia a relação de alienação de Tiãozinho, e que possibilita a identificação entre homens e bois, é o objeto da novela. A excepcionalidade da estória é conformada pelo modo como este objeto vem à tona: pouco a pouco o que era opaco a todos - bois, Tiãozinho, Agenor, narrador e leitor - abre-se em sentido à jusante da narrativa, quando o trabalho fantasmático - que é sina para os bois e para o menino e suas tensões específicas ganham local histórico. O excepcional, por fim, recai sobre o furo no mundo do trabalho, que a todo tempo mediou as relações no texto. Dito isto, e tendo em mente a noção de ficção que o interlocutor culto prometeu adicionar ao causo, pode-se dizer que a ficcionalidade esteve na construção desta tensão laboral, e a perspectiva da forma acaba sendo esta do furo. Ou, se quisermos, do sertão, que, como em Euclides da Cunha, aqui aparece como uma irrupção que aponta para uma situação impossível. Mas, ao contrário de Euclides, os deslocamentos da forma proporcionados por "Conversa de bois" permitem que o sertão perca seu aspecto fantasmático e assuma uma face. Este rosto, no entanto, aparece como espaço 
ambíguo, em que o mínimo espaço para o trabalho capitalista se transforma, da perspectiva sertaneja, em abismo. 


\section{A hora e a vez de Augusto Matraga}

Antonio Candido, no escrito "Radicalismos" (CANDIDO, 2004), esboça um panorama amplo do pensamento conservador do Brasil, que emerge com maior força, sistematicidade e consistência no período da Primeira República e no decorrer dos anos 1930. A composição não é complexa e a alcunha de 'pensamento reacionário' é precisa, uma vez que se trata de uma reação às mudanças estruturais pelas quais o país passava que paulatinamente deflacionavam o poder da grande propriedade no $\mathrm{Brasil}^{54}$. A resposta a este movimento, segundo Candido, se dá no plano do pensamento

\footnotetext{
${ }^{54}$ Esta deflação, é claro, deve ser entendida no sentido do significado colonial e neocolonial da grande propriedade. É evidente que, à medida que a propriedade torna-se em si meio de produção com fins capitalista, o latifúndio continua a exercer grande poder; seu proprietário, no entanto, não é mais da mesma extração dos grandes proprietários da Colônia ou do Império. O latifundiário capitalista exerce seu poder de outro modo e suas prerrogativas e interesses são outros. Creio que a ausência desta distinção é a causa de muitos problemas na interpretação de textos que versem sobre a Primeira República ou mesmo períodos subsequentes, como é o caso de Rosa.
} 
conservador como reiteração do que foi perdido, como "romantismo tradicionalista que valorizava a herança colonial em sentido senhorial e ufanista, destacando as alegadas virtudes morais, econômicas e políticas do que se chamava a aristocracia rural" (Idem, p.212, grifo no original). Candido destaca a obra de Oliveira Vianna de 1920, Populações meridionais do Brasil, como o texto de maior envergadura e influência no pensamento brasileiro desta extração: nesta obra em particular, o consórcio entre pensamento racista e autoritarismo na forma de uma 'teoria de governança' acaba por realçar os elementos que Candido tenta articular no artigo. A saber, o que o crítico chama de um traço indistinguível destes textos, mesmo que às vezes 'inconsciente', é o que ele chama de 'dever de tutela', “a ser exercida pelas elites sobre o povo ignorante, incapaz de perceber os próprios interesses, e que precisaria ser encaminhado no rumo mais conveniente à nação" (Idem, Ibidem).

A própria necessidade de uma teoria de governança nestes termos - e daí o sentido forte de pensamento reacionário - aponta para a própria crise no seio do patriarcalismo; isto é, a teoria é necessária para reconduzir a 'horda ignorante' de volta ao patriarcado. A ideia mesma de teoria e o arcabouço de conceitos que carrega (os de aristocracia rural e povo, sobretudo) se confundem com a noção de civilização, ensaiando assim uma entrada às avessas no pensamento formativo: o caminho para a civilização, via patriarcalismo, é o que se necessita encontrar para tamponar essa fratura social. A própria noção de 'tutela', portanto, é tributária a uma primeira divisão entre povo e elite esclarecida, o que, é claro, lança uma nota de suspeita sobre este esclarecimento 'à brasileira'. O importante, no entanto, é notar que este antagonismo - povo/elite - não é um achado do pensamento conservador. A matéria histórica da primeira república fornece os rudimentos para a sustentação enlutada da 
teoria conservadora, bem como para a nova volta do parafuso deste referente imprescindível, a noção de civilização ou esclarecimento.

Dado este quadro, é surpreendente a posição crítica de Luiz Roncari quanto a Rosa. O crítico acerta ao localizar na primeira república as tensões que alimentam o texto rosiano. Roncari, no entanto, ao investir na ideia de que Rosa alegoriza as tensões da história (ao invés de formalizá-las) acaba identificando o projeto estético do autor ao pensamento conservador de sua época. Afirma o crítico, sobre uma suposta 'terceira camada' do texto rosiano - diferente das duas outras camadas, a leitura histórica e que inseria o autor na tradição regionalista, e a segunda, que elaborava a "dimensão simbólica, universal e mítica das obras" (RONCARI, 2004, p.18):

Ela [a terceira camada] alegorizava a história da vida políticoinstitucional de nossa primeira experiência republicana e numa perspectiva que poderíamos considerar conservadora. Como crítica das instabilidades do novo regime, ela participava também, a seu modo, da nostalgia da 'ordem imperial', desencadeada pelas crises políticas e institucionais que se sucediam [...]. Desse modo, o 'conservador' aqui se manifestava não como uma defesa da ordem, mas como uma crítica dela e por uma outra ordem, restauradora do pai tutelar ou da autoridade que se havia perdido com a República (RONCARI, 2004, p.18-19).

A nostalgia de Rosa, a que Roncari se refere, liga-se à conhecida conjunção de dois fatores na obra do autor: a instabilidade ética e a figuração da violência interiorana. Para Roncari, a remissão da instabilidade à violência cria o ambiente para a alegorização de um projeto político, pois o primeiro termo se refere à situação de sucessivas crises políticas do país, e o segundo à prevalência da ordem privada sobre o bem público. Há a percepção do crítico de que a obra de Rosa atenta ao declínio do 
privatismo neocolonial, e em suas análises de Sagarana Roncari chama atenção à importância do entendimento do coronelismo para uma aproximação aos contornos da obra rosiana. Mas há, nesta aposta na alegoria como chave explicativa, o recurso a uma grave tautologia cujo desvendamento é essencial para a compreensão da perspectiva rosiana.

O curto-circuito se dá na própria concepção de coronelismo como sobrevivência do poder privado e de sua imediaticidade. Quando Roncari comenta “A volta do marido pródigo" e o quadro que a novela tece em torno do coronelismo, ele afirma:

O que ele [o telegrama recebido por Major Anacleto] descreve é um sistema essencialmente verticalizado de mando e pressão que vem de cima para baixo, da instância federal, a do Ministro, até a local, a dos pequenos coronéis, passando pela do Presidente do Estado, através do Secretário do Interior, e pela do Prefeito. [...] esse sistema não tinha pés-de-barro, ele era sustentado por pequenas realidades locais que formavam as suas contrapartidas e de cujo apoio também dependiam as esferas mais altas, daí o compromisso que se criava entre um sistema e outro, entre a 'política dos governadores' e a 'política dos coronéis'. Esse outro quadro, o do microcosmo local do mando disputado por vários coronéis, nos é dado por Lalino. Ele nos mostra como o autoritarismo e a violência, o mando e a capacidade de pressão, já não eram mais políticas, quer dizer, mediatizadas, mas diretas. Elas aconteciam para o arrebanhamento de votos, usados pelos coronéis como moedas de troca dos apoios políticos recebidos. [...] É o que acontecia na novela, a função política voltava-se para a busca dos benefícios pessoais. A perda do verdadeiro sentido dessa ação e a confusão que se estabelecia entre o público e o privado faziam da ética um vale-tudo, de tal modo que tornava tolerável qualquer transgressão (RONCARI, 2004, p.53-55, grifos meus).

O desenvolvimento do argumento do crítico é um tanto inesperado, pois descreve todas as etapas de mediação do coronelismo para, ao fim, afirmar que em sua base 
elas recaíam no privatismo e, portanto, na não-mediação. A questão da não-mediaçãomediada já foi discutida quando tocamos no problema em "A volta do marido", não cabendo portanto retomar o argumento de que a aparência de não-mediação esconde um tipo específico de mediação. O mais importante neste trecho - e o que aponta para a tautologia na crítica de Roncari - é a consideração de que a política se dá nas movimentações das instâncias oficiais e com algum lastro representativo e que, no momento em que esta política toca o chão, ela esbarra no mandonismo e, portanto, na não-política.

A tautologia acontece precisamente neste ponto: Rosa descreve o processo em seu enraizamento no 'vale-tudo' ético, provocado pelo mandonismo. Como, na visão de Roncari, há o reconhecimento do problema e uma falta de investimento naquilo que, a seu ver, tamponaria esta cesura entre ordem pública e privada (a saber, a aposta na civilidade), seus escritos devem ser identificados ao pensamento reacionário do período, que percebia a mesma falta mas remetia sua solução à nostalgia da autoridade patriarcal. Mas, como Candido tratou de mostrar, a própria separação de um polo positivo da política e outro negativo é ela mesma um subproduto do pensamento conservador: ele emerge ao mesmo tempo em que o próprio sertão se forma como objeto, em direta oposição a ele, como sintoma deste desgarramento das populações rurais do seio da propriedade neocolonial. Note-se portanto o curtocircuito: Rosa descreve ficcionalmente as relações coronelistas de uma perspectiva local, abrindo-as para os nexos que as envolvem como sistema. Este sistema, no entanto, é visto pelo crítico como naturalmente cindido - na contramão de todos os indicativos do texto rosiano. Há portanto uma interferência do próprio pensamento conservador - a cisão entre um polo positivo e outro negativo da política - no julgamento do crítico: e é este julgamento que permite a assunção de que o texto 
rosiano é alegoricamente vinculado às visões conservadoras do país. Em outras palavras, a semelhança entre Oliveira Vianna e Rosa só pode ser construída se adotarse de antemão a premissa de que realmente há a necessidade de um elemento para tamponar uma falta na política brasileira, que é a desconexão entre a plebe rural e a política. Somente após a assunção de que a cisão é verdadeira - de que realmente há a necessidade de civilizar-se e de que a 'horda rural', dependentes e coronéis incluídos, representa uma falta ou obstáculo a este movimento de civilização - é que se pode considerar o texto de Rosa como alegórico.

O fio condutor deste pensamento, como se vê, é uma noção abstrata de formação como processo civilizatório; e a própria consideração da obra de Rosa do ponto de vista alegórico - e não formal - revela a estratégia de subsumir a forma à dualidade abstrata dos polos positivo e negativo da política. Um exemplo do problema desta abordagem se dá na categorização do tipo de ação que tem lugar na obra rosiana. Esta se dá, de novo, como sintoma de uma cisão imaginada entre processos sociais e ideais utópicos; isto é, em termos literários, a referência ao bildungsroman europeu aparece como ideal de harmonia entre formação de sociedade e formação subjetiva. No caso de Grande sertão: veredas o problema aparece como paradoxo: como o texto pode inserir-se nesta tradição se apresenta ação e resultados heterônomos $?^{55}$ Ao referir-se ao famoso episódio do tribunal que julga Zé Bebelo no Grande sertão, Roncari se posiciona da seguinte maneira:

O processo do tribunal surgiu, por um lado, como a oportunidade de representar ao leitor, diretamente, as duas questões mais gerais e decisivas em discussão no romance: primeiro, a formação do herói, como pode alguém se formar num universo social estratificado e sem

\footnotetext{
${ }^{55}$ Retornaremos com mais atenção a este ponto no capítulo seguinte, no qual se confrontará diretamente a pergunta: à luz de Sagarana, é possível considerar Grande sertão: veredas um romance de formação?
} 
padrões civilizatórios minimamente fixados, o que levaria a um formar-se e deformar-se constante num nunca acabar; e, segundo, a da estruturação do lugar, as possibilidades e dificuldades de incorporação [...] das instituições modernas e civilizadas num mundo rústico. Por outro lado, o tribunal focaliza um momento ímpar, poderíamos dizer, de alta política, que é o da tentativa encabeçada por Joca Ramiro de instaurar outra ordem no sertão, que fugisse ao conflito entre as forças locais e as legais, ou, em outros termos, as do poder privado e as do poder público (RONCARI, 2004, p.264-265, grifos meus).

A crítica alegórica de Roncari quase mimetiza o efeito basculante do próprio romance em questão: entre a objetividade que o texto apresenta, encarada como impossibilidade de formação, e a alegoria civilizatória a que ele apontaria, o comentário vacila precisamente sobre a noção de justiça que se põe em xeque na ficção rosiana.

$\mathrm{Na}$ alegoria da civilidade, sertão e justiça são dois significantes incompatíveis - e deste deslizar entre padrões de incompatibilidade se acredita extrair o efeito de reversibilidade do texto. A subsunção do texto à abstração de justiça é necessária para justificar a abordagem alegórica, e neste caso a própria forma - sua tendência à reversibilidade, por exemplo - é subjugada a uma abstração que existe antes na crítica e no pensamento conservador e menos no texto em si. O que aconteceria, no entanto, se os termos da equação fossem invertidos? Se, através da perscruta do texto e de seu arranjo formal, buscasse-se a raiz da noção de justiça trabalhada por Rosa, como fica a ideia de civilidade: isto é, como a abstração se sustenta diante da apresentação formal do objeto-sertão?

Este rastreamento é facilitado pelo último texto de Sagarana: com efeito, em “A hora e a vez de Augusto Matraga" todos os elementos aqui em jogo - a relação do coronelismo e jagunçagem, a questão da justiça atravessando a noção de sertão - são 
postos em relação, tanto localmente quanto sistematicamente, criando um panorama amplo do sertão e revelando os desafios de sua apreensão formal. A análise da novela pode revelar a impostura de uma intenção alegórica no texto rosiano ao mesmo tempo em que, como as outras novelas aqui estudadas, permite vislumbrar o que seria uma formalização da questão do sertão na literatura. Vejamos, então, quais consequências traz a coabitação de justiça e sertão no mesmo nó formal.

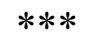

As intenções formais do texto são dispostas logo em seu primeiro parágrafo, em que o narrador demonstra uma clivagem voluntária de tons e escopos na narrativa: “Matraga não é Matraga, não é nada. Matraga é Estêves, filho do Coronel Afonsão Estêves, das Pindaíbas e do Saco-da-Embira. Ou Nhô Augusto - o homem - nessa noitinha de novena, num leilão de atrás da igreja, no arraial da Virgem Nossa Senhora das Dores do Córrego do Murici" (S, p.363, grifos meus). O sentido das conjugações entre negações e afirmações neste primeiro trecho da novela condiciona todo o sentido de sua construção. A afirmação inicial - 'Matraga não é Matraga, não é nada' - surge como enigma e quebra as expectativas do leitor quanto à estória que encontrará à frente. $\mathrm{O}$ desdobramento posterior, no entanto, elide a importância desta primeira função negativa que aparece logo no início da novela, e que se mostrará fundamental somente em seu desdobramento final. Com efeito, o narrador localiza a cena e insere o leitor num contexto muito específico - o leilão que acontece neste lugarejo no interior de Minas -, ponto do qual a narrativa firma sua base e prepara as reviravoltas que condicionarão seu fecho. 
A retenção do sentido desta primeira micro-reviravolta entre uma negação contundente e um posterior desdobramento processual deve todavia passar por um primeiro escrutínio, que sustentaria a ideia de que "A hora e a vez de Augusto Matraga" já coloca sob suspeita, logo de cara, qualquer alegorização de seus efeitos formais. Primeiramente, esta micro-reviravolta coloca o narrador numa posição curiosa: ele segura o resultado de todo o desenvolvimento ulterior consigo, mas ainda assim exerce um efeito elusivo ao afirmar uma identidade em todo negativa ao que seria Matraga: ao afirmar que Matraga não é Matraga, o narrador claramente se refere ao título da novela sob a forma de desmentido: ou seja, em parte coloca-se ao lado do leitor, que espera uma estória sobre Augusto Matraga (ou, como diria Roncari, a saga de um herói). Mas o complemento não é um nome - o que se vê logo acima não é o que qualifica o herói como sujeito. Ao afirmar, portanto, que 'Matraga não é Matraga', o narrador no fundo diz que não se trata da estória de formação de um sujeito, pois Matraga não é um título a que Nhô Augusto terá acesso ao final de seu périplo, como resultado de sua construção como personagem. Matraga também não é um adjetivo que ele, o narrador, pode atribuir qualificando esta construção: de fato, Matraga não é nada neste sentido.

A inflexão de tantas negações no início do texto condiciona a narrativa a uma situação peculiar: o narrador tem conhecimento da estória de Nhô Augusto e reclama também o saber sobre o que é Matraga. Mas este saber coloca-o numa posição de estranha subserviência, pois a nomeação de Matraga não seria seu atributo, mas sim o resultado do próprio desenvolvimento da trama. Deste modo, o narrador é o portador da voz que sabe, mas apenas como veículo ou portador deste saber. O conteúdo do saber só pode ser acessado através da narrativa e das relações que ela mesmo sugere. Como se verá à frente, a definição do que é Matraga - ou melhor, como o termo se 
constitui somente como suporte de uma certa relação - colocará em xeque a noção alegorizada de justiça, justamente por surgir do tecido da própria forma. Uma pista desta relação é dada nesse parágrafo inicial, no qual a afirmação de que Matraga não é nada é logo seguida pela afirmação: 'Matraga é Estêves...'. A partir do momento em que o narrador se propõe a escrutinar a personagem, torna-se claro que a saga do herói não pode ser ignorada no entendimento do que é Matraga. Resta somente a pista de que esta definição deve passar por esta dobradura entre a negação da constituição subjetiva e sua afirmação pela narrativa.

Por ora, no entanto, cabe-nos acompanhar o narrador a partir de seu momento de inflexão positiva - isto é, a partir do momento em que de fato começa a tecer a imagem de Nhô Augusto, num salto vertical destas relações de 'não-ser' de Matraga para suas relações de 'ser'. 'O homem', como ressalta o narrador, este se encontra num lugar e situação muito específicos, em que se iluminam os primeiros traços sobre a personagem. O narrador coloca o leitor prontamente em situação, da qual o esboço de Nhô Augusto é deduzido via suas ações no leilão sem graça da igrejinha do interior. A apatia do evento logo dá lugar à arruaça quando a "multidão encachaçada de fim de festa" começa a querer leiloar as duas "mulheres-à-toa" (S, p.363) que ali estavam. O significante animal volta a aparecer aqui para marcar a posição social das mulheres: uma, a branca, com pescoço fino e pernas finas, foi logo apelidada de Sariema e entrou no leilão como qualquer outro animal. Quando os lances começam, Nhô Augusto logo entra em cena e arrebata a mulher por cinquenta mil-réis.

O momento importa por vários fatores: primeiro, a já sugerida reificação da 'mulher-à-toa', que fica à deriva neste jogo estritamente masculino, servindo apenas como referente para a auscultação daquele microcosmo de poder. Na pequena cena, o poder econômico não se distingue do título de Coronel que Nhô Augusto ostenta e, 
para todos os efeitos, o dinheiro é apenas símbolo deste poder. Isto é, ao contrário de um leilão normal, em que uma transação ocorre, o dinheiro ali tem a mesma eficiência de uma arma empunhada: é signo de poder, inalienável e ligado à pessoa de Nhô Augusto $^{56}$. A impostura monetária de Nhô Augusto se apoia decerto sobre sua proeminência social, e com isso serve para reclamar a posse de Sariema. Esta proeminência, no entanto, não existe em absoluto: ela se mantém em relação aos demais capiaus que o aplaudem, reconhecendo-a, ou via rivalidade, que se estabelece entre Nhô Augusto e um sertanejo que apresenta um interesse não-monetário pela moça.

Após encenar a compra, Nhô Augusto faz coro ao pedido do leiloeiro para que se dê fim à bagunça, pois se tratava de um leilão em terreno sagrado: "Sino e santo não é pagode, povo! Vou no certo... Abre, abre, deixa o Tião passar!” (S, p.365). Ao derrubar a própria prerrogativa do leilão que ele mesmo endossara, torna-se clara a impostura de Nhô Augusto. Mas quando o capiauzinho tenta falar baixo ao ouvido da moça, para que aproveitassem a situação para irem embora, a posição de Nhô Augusto muda novamente: ele se coloca entre os dois, apoiado por seus quatro guarda-costas, e reclama novamente o direito sobre a moça. O povo grita: “-É do Nhô Augusto... Nhô Augusto leva a rapariga" (Idem, Ibidem). O resultado da contenda é a esperada: o capiauzinho perde a posse sobre a moça e sai apanhando dos quatro capangas de Nhô Augusto. Logo em seguida, no entanto, o fazendeiro a descarta dizendo que ela tinha "perna de manuel-fonseca, uma fina e outra seca", mandando-a embora.

\footnotetext{
${ }^{56}$ À frente veremos como, ao contrário de Roncari, este significante do dinheiro não é sinônimo de imediaticidade de poder. Veremos como o problema do jaguncismo se relaciona ao dinheiro.
} 
O que o episódio demonstra, para além da brutalidade com a mulher, é que a relação do capiau com a moça era objetal, no sentido de que ele a queria como objeto de afeto. No caso de Nhô Augusto, o objeto de seu desejo era o poder, que percorria o seguinte trajeto: o interesse na Sariema somente atravessava-a como forma de se contrapor ao capiau. A mulher, neste caso, acaba se igualando ao dinheiro na primeira situação: é apenas a instância que o poder de Nhô Augusto precisa atravessar para a contraposição aos homens pobres do vilarejo. Portanto, da mesma forma como a intervenção de Nhô Augusto constitui-se como poder ao atravessar a transação comercial do leilão, o mesmo se dá com a relação entre o capiau e Sariema: a possibilidade de atravessar o desejo do dependente lhe configura o poder.

Tem-se nesta cena despretensiosa, que abre a novela, a primeira armadura do esquema do poder coronelista. Nele, revela-se um triângulo que constitui a situação de poder entre o dependente, o objeto de seu interesse (a moça no caso), e a ascendência de Nhô Augusto. O poder exerce-se aqui não de forma imediata, como sugere Roncari e outros críticos, mas necessita dos outros dois termos do triângulo para realizar-se. Poder-se-ia, contra este argumento, afirmar-se o que é óbvio: tudo poderia não passar por apenas um exercício perverso de Nhô Augusto, com o único intento de interpelar o objeto de desejo do capiau para infligir-lhe alguma violência. A estrutura da perversão é correta, mas acredita-se que Nhô Augusto a coloca em movimento não porque quer, mas porque pode e em certo sentido deve. Em outras palavras, o poder não lhe é imanente, mas é situacional e deriva da capacidade de atravessar o desejo dos dependentes, o que acaba definindo sua prerrogativa coronelista.

A contraprova que sustenta essa hipótese é a função que o dinheiro parece exercer no poderio coronelista. Mais à frente, sobre Nhô Augusto, o narrador afirma: 
"Mais estúrdio, estouvado e sem regra, estava ficando Nhô Augusto. E com dívidas enormes, política do lado que perde, falta de crédito, as terras no desmando, as fazendas escritas por paga, e tudo de fazer ânsia por diante, sem portas, como parede branca" (S, p.369, grifo meu). O acento sobre sua condição econômica decadente é logo seguido pela apresentação do drama de sua mulher, Dionóra. Ela apaixonara-se por outro homem e este outro "era diferente! Gostava dela, muito... [...] da maneira que a gente deve gostar" (S, p.369). Mas, se Dionóra aceitasse ir com este outro, "Nhô Augusto era capaz de matá-la" (Idem, Ibidem). Tem-se assim a mesma configuração anterior: a mulher de Nhô Augusto tem um objeto de desejo - o outro que a ama de um modo que é diferente de seu marido, isto é, um desejo que a encontra enquanto objeto de amor também, não somente a atravessa como o desejo do proprietário. A prerrogativa de poder de Nhô Augusto neste caso seria clara na obstrução desta relação entre intenção-objeto: ele a mataria, assim como espancou o capiau no leilão. Mas, mesmo diante do perigo, Dionóra segue com seu objeto de amor e foge: isto porque, como afirma Quim Recadeiro ${ }^{57}$, ‘a casa estava caindo'.

Diante da notícia de que sua mulher o abandonara, Nhô Augusto segue adiante com sua prerrogativa de poder coronelista: ele chama os capangas para completar o triângulo e obstar o desejo de sua dependente. Mas, quando Quim responde ao comando do patrão e convoca os capangas, estes recusam-se a atendê-lo. O fato tem importância crucial na trama e ajuda a dar contornos claros à espécie de desmoronamento do poder de Nhô Augusto: embora as demais instâncias de seu poder dessem sinais de desgaste - política do lado que perde, falta de crédito - a engrenagem coronelista de Nhô Augusto realmente emperra quando sua relação com os capangas sofre um corte. No que concerne à relação com seus bate-paus, não se

\footnotetext{
${ }^{57}$ Quim Recadeiro talvez seja o único dependente que acredite na imanência do poder de Nhô Augusto, por isso sua fidelidade cega ao patrão.
} 
trata do mesmo tipo de abandono que sua mulher lhe infligira. $\mathrm{O}$ abandono dos capangas revela um traço fundamental da política coronelista:

Dali a pouco, porém, tornava o Quim, com nova desolação: os batepaus não vinham... Não queriam ficar mais com Nhô Augusto... $O$ Major Consilva tinha ajustado, um e mais um, os quatro, para seus capangas, pagando bem. Não vinham, mesmo. O mais merecido, o cabeça, até mandara dizer, faltando ao respeito: - Fala com Nhô Augusto que sol de cima é dinheiro!... P'ra ele pagar o que está nos devendo... E é mandar por portador calado, que nós não podemos escutar prosa de outro, que seu Major disse que não quer. (S, p.372, grifos meus).

Aqui se vê a importância do dinheiro na relação com os capangas, um dado que desafia a visão patrimonialista do coronelismo: a saber, a noção de que o sistema é uma mera reminiscência colonial. Como se vê, o poder de Nhô Augusto não é derivado diretamente da terra, do mesmo modo que seus dependentes têm a prerrogativa de circular nos interstícios da propriedade, o que indica que o poder passa pela terra mas não é seu lastro último. O dinheiro, no entanto, tampouco se configura como este mesmo lastro, o que se esperaria de uma sociedade industrial constituída, na qual a propriedade privada assume outra função: a de meio de produção. Afirma-se isto pois a relação monetária com os capangas ainda é atravessada pela pessoalidade da lealdade, por um lado, e do desafio, como mostra o desaforo vindo do chefe dos jagunços de Nhô Augusto. Em outras palavras, trata-se de uma relação monetária que ainda atravessa a pessoa do coronel: melhor dizendo, atravessa sua capacidade de sustentar seu poder.

É exatamente a esta prerrogativa que Quim se refere no seu conselho ao chefe: “Mal em mim não veja, meu patrão Nhô Augusto, mas todos no lugar estão falando que o senhor não possui mais nada, que perdeu suas fazendas e riquezas, e que vai 
ficar pobre, no já-já” (Idem, Ibidem). O contraste deste momento da trama com seu primeiro movimento, na cena do leilão, no qual a pessoa de Nhô Augusto era incontestável e seu poder se expressava pelo dinheiro, não como poder econômico, mas poder coronelista, é de fundamental importância para o entendimento dos tipos de mediação coronelistas. Ao mostrar a corrupção deste mesmo poder, a narrativa mostra a mesma face do dinheiro menos como moeda e mais como peça de sustentação do poder do coronel. A debandada dos jagunços, neste cenário, redireciona a atenção do texto à relação entre dinheiro, propriedades, crédito e poder, no qual o papel dos próprios jagunços é essencial.

De certo modo, é possível afirmar que a jagunçagem é o próprio fiel da balança deste nexo e, curiosamente, "A hora e a vez de Augusto Matraga" se constrói como imagem espelhada da novela já analisada, "A volta do marido pródigo". Se nesta mostrou-se o ciclo de acumulação coronelista rodopiar até encontrar o eixo na asseguração da vitória política do Major Anacleto, expressa na efetividade do uso de seus capangas, o quadro mostrado em "A hora e a vez" é o inverso: os jagunços escapam à órbita do coronel no momento de sua debacle, que neste contexto mostrase como a impossibilidade de dar corda à mesma ciranda de acumulação primitiva que discutimos anteriormente.

Trata-se do mesmo quadro complexo, a que iremos nos referir mais adiante. Por ora, cabe notar que o movimento da roda coronelista envolve e sustenta, in nuce, o refluxo de poder sobre a pessoa do coronel via dois caminhos: por um lado está a sua capacidade de atravessar a vontade de seus dependentes de modo a garantir uma orquestração política que lhe favoreça (o famoso voto de cabresto, por exemplo); esta relação, decerto, aponta para uma face do Estado, capaz de lhe garantir sua sobrevivência em formas de favores, garantias políticas e acesso a crédito. 
Do outro lado, o poder reflui ao coronel sob a forma de dinheiro, com os frutos de sua produção para o mercado interno. Aqui se encontra o estatuto ambíguo da propriedade rural, pois o dinheiro reflui não como lucro a ser reinvestido na produção, mas como própria sustentação do poder pessoal do coronel. Isto é: o dinheiro funciona como lastro da roda da política, na qual as articulações do coronel assumem a feição de mandonismo e violência em suas duas frentes: nas relações políticas com dependentes e adversários; na relação com a terra e o trabalho, sob o imperativo de expansão horizontal da produção.

É este o quadro que Luiz Bernardo Pericás esboça sobre o funcionamento básico do coronelismo, no estudo focado sobre os grupos independentes de cangaço: “um dos padrões de conduta mais comuns dos 'coronéis' era a apropriação de terras e pequenas fazendas pela força das armas ou a sua compra de sertanejos endividados [...]. Iam se apoderando de tudo em que pudessem colocar as mãos” (PERICÁS, 2010, p.27, grifos meus). A caracterização é feliz ao igualar as armas ao uso do dinheiro para compra de terras a preços irrisórios. Em ambos está a pressão, livre e direta, do jaguncismo sobre a pequena propriedade e seus ocupantes. A pressão traz consigo o papel ambíguo do dinheiro neste processo, como fica patente em outro trecho do historiador: ao lançar comentário sobre os grupos independentes de jagunços (e em especial o famoso grupo de Lampião no nordeste brasileiro), Pericás afirma:

Antônio Silvino agia como líder militar e também como patrão, acreditando que assim garantiria a lealdade dos jovens que lutavam a seu lado em seu bando. Quando os 'recrutas' abandonavam o grupo, Silvino chegava a encaminhá-los para trabalhar com fazendeiros amigos seus. Os cangaceiros que ficavam recebiam um salário diário. Alguns anos mais tarde, os homens de Lampião supostamente ganhariam 30 mil-réis semanais (Idem, p.52, primeiro grifo no original, segundo grifo meu) 
Este duplo caráter da jagunçagem, estranho à primeira vista, pode causar confusão no momento de sua interpretação. Isto porque os grupos independentes de jagunços, que tiveram sua existência vinculada ao cenário da primeira república, assumem quase a qualidade da 'prestadores de serviço' aos coronéis. Isto é, os jagunços se inseririam no processo produtivo ao colocar-se como peça necessária para a expansão horizontal do capital; o dinheiro que a eles refluiria faria parte portanto dos custos de produção no interior, arcados pelo fazendeiro. Esta é uma afirmação em aparência verdadeira; mas um olhar contido às ambiguidades do jaguncismo revela mais sua pertença ao coronelismo do que a um sistema de produção em que a ideia de prestação de serviços fizesse sentido.

Para efeito de argumentação, pode-se afirmar que não deixa de ser verdade que um serviço era prestado; ressalta-se apenas que o caráter de sua contraparte monetária não é inteiramente abstrata - como se esperaria de uma transação em moeda num cenário capitalista-industrial formado. Outra passagem da obra de Bernardo Pericás nos ajuda na compreensão deste ponto: afirma ele que "todos esse líderes cangaceiros [...] vinham de famílias tradicionais e de relativas posses, respeitadas em suas regiões". (PERICÁS, 2010, p.33). Adiante, o autor completa o raciocínio:

Assim, o que se pode dizer é que, em geral, muitos desses bandoleiros se identificavam com um grupo de famílias de prestígio ou até mesmo com outros coronéis locais, e não necessariamente com os 'pobres'. [...]/ Não apenas esses chefes de quadrilhas tinham uma origem social mais alta que a maioria dos sertanejos, mas também preferiam se relacionar com as elites locais, com quem sentiam mais à vontade e com quem poderiam se associar nos negócios (Idem, p.35, primeiro grifo no original, segundo grifo meu). 
$\mathrm{O}$ argumento decerto tem uma função clara: retirar a aura em torno destes grupos e mostrá-los em perfeito consórcio com as políticas coronelistas. O interesse para nós, no entanto, está precisamente na natureza destes 'negócios' realizados no interior do sistema coronelista. Não se trata de negócios que necessariamente promovam a fluidez de capital, mas uma sorte de negócios muito parecida com dos próprios coronéis: acumulação de terras, negociação de favores públicos etc.

Em resumo, o jaguncismo não se insere como parte inalienável do sistema coronelista porque é prestador de serviços à produção ${ }^{58}$, facilitando assim a circulação de capital sob a forma de mercadorias. O jaguncismo faz parte da engrenagem da primeira república porque tomam parte precisamente 'dos negócios coronelistas', que, na falta de melhor termo, chamaremos apenas de 'poder coronelista'. O dinheiro circula portanto, nas mãos dos jagunços, como visto acima, não como capital, mas como função agregada do poder coronelista, que assume aqui o papel de ente circulante. Isto é: o dinheiro não flui como entidade abstrata, mas como parte acoplada ao poder dos coronéis, função na qual a pessoa do coronel serve de ponto agregador deste poder. O jaguncismo portanto imiscui-se num nó em que, de um lado, lealdade e respeito ao coronel/chefe jagunço são importantes; e, de outro, em que a moeda confere consistência a ambas as partes da equação. Em outras palavras, neste cenário a lealdade não existe sem o dinheiro, assim como o dinheiro não existe sem lealdade.

Neste sentido, é interessante notar o depoimento de um antigo jagunço, em conversa com o amigo sertanejo, recolhido por Pericás:

\footnotetext{
${ }^{58}$ Isto não significa que o jaguncismo não se vincula à produção. Veremos mais à frente, com maior detalhes, como isto se dá.
} 
Zé Divino, meu velho, és um louco, passando a vida inteira curvado sobre a tua enxada, que só te dá 500 réis por dia./ Pois não vês que um mês de trabalho teu te vale 12 mil-réis; enquanto que eu tenho por dia o dinheiro que quero, 10, 20 mil-réis, que os meus patrões me dão, de medo do meu rifle? (PERICÁS, 2010, p.57, grifo no original, segundo grifo meu)

O depoimento deixa claro qual extrato da população compõe o corpo da jagunçagem; o raciocínio econômico por trás da escolha pelas armas é também interessante, pois demonstra em que medida se trata de um fenômeno original da primeira república e menos uma reminiscência da violência colonial. O mais importante, no entanto, é a percepção de que a contraposição à lida de subsistência constitui aspecto estruturante do jaguncismo: no trecho, não se trata apenas de afirmar que a jagunçagem é mais lucrativa do que o trabalho no campo, mas precisamente que o trabalho na terra é monetariamente inócuo, enquanto que o trabalho em armas recebe uma retribuição em moeda que invariavelmente se vincula à fidelidade ao grupo jagunço. Ou seja, o jagunço não se coloca como trabalhador livre, uma vez que sua relação com seus 'patrões' não conforma uma transação trabalho/salário ${ }^{59}$, mas como fruto de uma relação em que dinheiro, violência e fidelidade compõem a única rede de financeirização possível no sertão, inalienável à circulação de poder coronelista. Trocando em miúdos, dir-se-ia: do lado da lida de subsistência, há um vácuo financeiro que se deve menos à falta de moeda e mais à impossibilidade de abstração

\footnotetext{
${ }^{59}$ Refere-se novamente à relação entre tempo, trabalho e produção de mercadorias. Nesta relação, a retribuição salarial constitui-se como contraparte abstrata à alienação, entendida como inacessibilidade aos meios de produção. Ou seja, o componente do tempo de trabalho passa a importar nesta relação pois comunica às mercadorias o 'trabalho abstrato', componente da produção que se constitui como falta de meios de subsistência. À frente trataremos da relação de alienação no contexto coronelista; pode-se adiantar, no entanto, que, embora haja uma relação entre falta e corte no trabalho de subsistência, o que se comunica não o trabalho abstrato à mercadoria, e sim a relação de poder coronelista ao círculo de acumulação cafeeira.
} 
do trabalho em forma de salário. Trata-se de um cenário que faz coincidir um trabalho e uma dependência que tendem à totalidade.

Do lado da jagunçagem, o dinheiro tampouco carrega valor: como aponta o depoimento do velho jagunço, o nexo entre moeda e trabalho não é mediado por relações entre tempo e mercadoria, mas é no fundo a coagulação de efetividade da função de poder em relação ao coronel, ou seja, efetividade no fluxo do poder coronelista. Ao se falar de uma efetividade do poder, diz-se da impossibilidade de este se sustentar sem essa coadunação que possibilita o fluxo coronelista: em última instância, o papel de ponta-de-lança dos jagunços é o que sustenta esta circulação de poder. Trata-se de uma observação importante para entender "A hora e a vez de Augusto Matraga" em sua dramaticidade: a perda do apoio dos capangas marca na novela um ponto de virada irreversível, pois o edifício coronelista, quando cai, desaba de uma vez. Isto porque dinheiro e poder perdem seu vínculo e consequentemente sua consistência mútua.

Este aspecto do coronelismo é claro na novela, marcado por uma anotação do narrador quanto aos 'infortúnios' de Nhô Augusto:

Assim, quase qualquer capiau outro, sem ser Augusto Estêves, naqueles dois contratempos teria percebido a chegada do azar, da unhaca, e passaria umas rodadas sem jogar, fazendo umas férias na vida: viagem, mudança, ou qualquer coisa ensossa, para esperar o cumprimento do ditado: 'Cada um tem seus seis meses...'/ Mas Nhô Augusto era couro ainda por curtir, e para quem não sai, em tempo, de cima da linha, até apito de trem é mau agouro. Demais, quando um tem que pagar o gasto, desembesta até o fim. E, desse jeito, achou que não era hora para ponderar pensamentos $(S, p .373$, grifos meus). 
O narrador delineia a diferença entre a má-sorte de qualquer capiau à de Nhô Augusto: do sertanejo, esperar-se-ia a cautela nas ações e sobretudo a fuga do lugar de querela. Deixar a poeira abaixar, neste sentido, denota a posição de dependência em que o capiau se encontra: se o parâmetro de justiça - o próprio fluxo de poder coronelista - lhe é inacessível, sobram-lhe duas opções, a fuga ou o conflito que, sem qualquer mediação, envolve toda sua pessoa ${ }^{60}$. Mas o grande fazendeiro é a personificação da justiça na medida em que recebe o influxo de poder coronelista e deve agir no comando de seus jagunços. Ou seja, para Nhô Augusto a ação é imperativa, pois é a própria ação de intervenção violenta que dá consistência à sua posição de poder.

Como se vê, o erro de cálculo de Nhô Augusto não é tanto a falta de ponderação, mas a desconsideração do fato de que, a partir do momento em que perde o suporte dos capangas, ele não mais ocupa posição nenhuma no quadro do sertão. Esta ação no vazio, portanto, é o que configura sua bravata e seu destino. Ao chegar na fazenda do Major Consilva, este lhe diz: “ - Tempo do bem-bom se acabou, cachorro de Estêves!" (S, p.374). Sem nem apear do cavalo, Nhô Augusto recebe o golpe de seus antigos bate-paus, que iniciam o linchamento. “- Arrastem lá p'ra longe, para fora das minhas terras... Marquem a ferro, depois matem" (Idem, Ibidem).

\footnotetext{
${ }^{60}$ Um paralelo com a novela "Duelo", neste ponto, é inevitável, pois nela mostra-se a mesma situação encontrada em "Augusto Matraga" vista de um ângulo invertido: isto é, da perspectiva dos capiaus. O texto gira em torno desta espécie de cálculo sertanejo, entre fugir e aceitar o confronto, e neste sentido é um texto essencial na caracterização dos 'espaços médios' do sertão. A saber, estes espaços de atividades insossas, em que o sertanejo pode se alocar nos interstícios do fluxo de poder coronelista. O vaivém de perseguição mútua, de cálculo constante, entre Turíbio Todo e Cassiano chega a um termo precisamente quando ambos deixam este espaço médio: um segue para São Paulo, para trabalhar no café, e o outro vai até a beira do sertão, no povoado de Mosquito, onde sequer capangas há para levar a cabo o serviço de vingança. A novela ajuda a perceber, portanto, que o sertão é um espaço delimitado, e apresenta seu interior e suas franjas, e deste modo caracteriza o espaço de cálculo sertanejo dentro do círculo coronelista. Voltaremos à comparação com "Augusto Matraga" quando este círculo estiver melhor definido.
} 
O sentido da marcação a ferro remonta à discussão da animalidade, a que já nos referimos em capítulo anterior. Cabe apenas notar que a mera morte de Nhô Augusto não seria suficiente para a significação completa de sua queda. A saber, o assassinato simples o colocaria no mesmo nível dos dependentes do Major Consilva: este então, para denotar um descenso para aquém deste nível, marca-o como boi, sua propriedade, e ordena sua morte. Da varanda, o Major pergunta: “ - Não tem mais nenhum Nhô Augusto Estêves, das Pindaíbas, minha gente?!.../ E os cacundeiros, em coro:/ - Não tem não! Tem mais não!...”(Idem, p.375).

Assim se define a morte social de Nhô Augusto como o fechamento de um ciclo coronelista: Nhô Augusto não apenas desaba; o fazendeiro não vai à falência, decaindo na escala social. A habitação do vácuo coronelista - que, como se mostrou, significa a incapacidade de fazer circular o poder - significa a pronta apropriação deste espaço por outro coronel, que passa a ocupá-lo, expandindo seu domínio. Neste sentido, a morte social de Nhô Augusto revela mais um aspecto jurídico do sistema coronelista: o nexo entre terras e dependentes lhe é inteiramente cortado a partir do momento em que nas duas esferas é incapaz de intervir com seus jagunços. Ou seja, há um sentido muito específico de propriedade que habita esta relação: a propriedade é ligada à pessoa do coronel, como indica a fala do Major Consilva ao adicionar ao nome de Nhô Augusto seu topônimo, das Pindaíbas. A terra lhe dá o nome, bem como o contrário também é verdade. Mas tudo depende de como o fazendeiro age nesta posição: a propriedade não lhe está assegurada por direito, tampouco os dependentes que dela dependem.

O direito é feito através da ação do proprietário, cabendo-lhe sua manutenção através da atividade econômica, por um lado, e a articulação política por outro. Em ambos os casos, agem os capangas, que estão em relação direta com o coronel. Neste 
sentido, portanto, o direito à propriedade não é uma entidade abstrata - como o é numa sociedade industrial - tampouco pessoal - como a colonial. O arranjo coronelista é original neste sentido: mais importante ainda é a noção de que a sustentação do direito à propriedade deve depender de alguma ação e de um movimento específico do fazendeiro: seja na apropriação de mais terras, na coação de dependentes e fazendeiros menores na política, e na arregimentação de mão-de-obra, este movimento define a posição do coronel e dá consistência a seu direito. Mais importante, na ponta deste processo estão os jagunços. Como são entidades inseparáveis - a posição coronelista e sua aliança com os jagunços -, Nhô Augusto perde-as ao mesmo tempo e as vê sendo apropriadas por outro proprietário, que, ao eliminar o adversário, passa a exercer seu direito.

Esta noção de direito, como veremos, será fundamental para o desenrolar da novela e para a transformação de Nhô Augusto em Matraga. Uma vez exposta a posição do coronel, a novela passa a explorar a posição do dependente. Neste movimento - e tendo as noções de direito e violência como suporte - a novela tece seu quadro do sertão.

A reviravolta na trama de "A hora e a vez de Augusto Matraga" é conhecida: Nhô Augusto, logo após ser marcado a ferro por seus antigos capangas, e imediatamente antes de ser executado, tem um lampejo de consciência e se joga barranco abaixo. Os bate-paus imaginam que ele perecerá por ali mesmo, dão por feito o trabalho, e armam uma cruz para colocar no local e evitar vinganças póstumas. Logo se descobre, no entanto, que Nhô Augusto não morreu; foi resgatado por um 
casal de negros pobres que moravam na base do morro, na boca de um brejo. Estes cuidam do moribundo e recolhem o material para já montar seu esquife, preparandose para a hora do "Diga Jesus comigo, irmão" (S, p.376). Mas Nhô Augusto escapa da morte, num gesto que caracterizará o resto de sua trajetória: o ex-proprietário de repente abre os olhos e pede " - Me matem de uma vez, por caridade, pelas chagas de Nosso Senhor..." (Idem, p.377). Depois da ordem, não atendida, ele delira sobre sua vida passada, "só braveza de matar e sangrar" (Idem, Ibidem). O conteúdo dos devaneios assusta a preta, que afirma: "E ele chama por Deus, na hora da dor forte, e Deus não atende, nem para um fôlego, assim num desamparo como eu nunca vi!" (Idem, Ibidem).

O gesto de Nhô Augusto funciona em função desse desamparo, que é no fundo a sobrevivência fantasmática da posição coronelista. A saber, o desamparo se constitui como sombra de uma subjetividade que é só vontade, no sentido já exposto: uma subjetividade que subsiste na medida em que comanda alguma ação, mesmo que seja o controle sobre o próprio corpo. A angústia de Nhô Augusto, neste sentido, se estabelece como inverso da resignação sertaneja, à qual a figura de Deus, como expressa pela negra velha, assume posição de significante essencial. Isto porque, como a sertaneja afirma, o desespero de Nhô Augusto se mostra como medida do pedido feito a Deus: no caso sertanejo, o ajuste feito junto à figura de autoridade Deus - se dá na mesma chave do tipo de demanda posta à figura do proprietário. Isto é, na dupla chave lealdade/compromisso, na qual o sertanejo reconhece a autoridade Deus/proprietário no mesmo ato de pedir algo. O pedido de Nhô Augusto, junto a Deus, é um pedido impossível, pois sua volta à posição anterior é inegociável. Neste não-lugar de sua vontade, Nhô Augusto mede seu desespero junto a Deus. 
Seguimos aqui o conhecido argumento de Maria Sylvia Franco no estudo de populações sertanejas. A autora joga luz precisamente na ambiguidade presente nesta relação em que o próprio reconhecimento do estatuto de pessoa do sertanejo, que lhe imprime os direitos e compromissos desta nivelação com o proprietário, define o caráter da dependência entre ambos. Franco afirma: "o fabricar de lealdades e fidelidades por meio de um processo cumulativo de recíprocos encargos e favores promovia, sucessivamente, a eliminação completa da possibilidade de um existir autônomo". Para a autora, “os efeitos desse processo não param no nível da orientação da conduta, [...] eles atingem até a própria consciência do mundo social, impossivel de ser concebido senão mediante o prisma formado pela encarnação do poder" (FRANCO, 1997, p.94, grifo meu) ${ }^{61}$. Franco se refere ao fenômeno de

\footnotetext{
${ }^{61}$ Existe, nesta citação, a supressão de um excerto fundamental. A autora afirma que a situação de dependência tem o efeito de cancelamento da "racionalidade mínima que implica a representação subjetiva de motivos e fins" (FRANCO, 1997, p.94). A discussão sobre a racionalidade sertaneja é de grande envergadura, e, no caso de Franco, claramente denota uma posição frente ao objeto que acaba dependendo do significante "racionalidade". É certo que, para Franco, o termo se refere ao tipo de abstração mental necessária para algum distanciamento perante a lei, que é afinal o que define a noção de direito positivo. O sentido marxiano de abstração também não foge ao alcance da análise, pois com esta afirmação a autora reitera o que repetimos ao longo deste trabalho: a noção de trabalho abstrato é a base necessária para qualquer tipo de abstração do direito. Esta consciência da autora acaba realçando qual era a discussão de fundo na época de escrita de Homens livres na ordem escravocrata: havia um interesse, próprio da tradição em que a autora se insere (que podemos chamar de formativa) em entender a peculiaridade deste objeto (a dependência sertaneja) e vislumbrar os motivos por que ele não se insere nos modelos de formação clássica do campesinato. A falta de racionalidade, neste sentido, funciona para a autora como balança desta relação teórica: por um lado, a autora reconhece a ausência de uma abstração jurídica como traço que define o caráter peculiar do capitalismo brasileiro. Mas, ao invés de ser visto somente através de um ângulo simpático (afinal, atribui a este traço do objeto a impossibilidade de formar-se como alienação clássica), a autora aponta para outro tipo de alienação que se tece na malha desta dependência. Racionalidade e alienação andam juntos no argumento da autora, conjunção que em muito lembra a ambiguidade de Marx quanto à mesma ideia de direito. O direito ligado ao sujeito abstrato, muito embora possibilite a dominação capitalista, pelo menos retira este sujeito do jugo da dominação pessoal, liberando algumas das possibilidades humanas como a própria ciência. Não se discorda do argumento de Franco, muito menos do que significa como achado e consequência (a dominação sertaneja). A única ressalva que fazemos diz respeito à própria ideia de 'realização das capacidades humanas', nas quais se inseririam o raciocínio entre meios e fins e à qual se agregaria um conteúdo libertário. A discussão é extensa e privada de consenso, mas nossa posição ao longo deste trabalho foi a de mostrar que este tipo de projeção de sentido sobre a racionalidade é, mais do que qualquer coisa, uma excrescência utópica (a ideia de formação
} 
concentração de poder e terras nas mãos do proprietário, e suas consequências à noção de direito que carrega. Como se viu, o cenário coronelista apresenta algumas complicações a esta caracterização, advindas muito em função da inserção da figura do jagunço neste quadro. Voltaremos a este ponto adiante.

Por ora, e voltando à novela, cabe notar que a esta disposição da dependência condiciona o sentido hagiográfico que tomará as rédeas de "A hora e a vez de Augusto Matraga". O foco em Nhô Augusto após sua morte social revela uma estratégia formal de alta potência: neste novo arranjo narrativo, as figurações de direito e justiça estarão submetidas a um escrutínio vindo de uma posição dupla ${ }^{62}$, a saber, a posição fantasmática do coronel decaído, e a posição de dependência, agora enfocada graças ao universo social que Nhô Augusto passa a ocupar.

Esta dupla negociação é o que dá consistência e sentido ao percurso de ascese de Nhô Augusto, em curso desde o primeiro momento em que a noção de Deus é introduzida na trama. Logo fica claro que o mesmo Deus dos sertanejos não é o Deus do patriarca; no entanto, mesmo não coincidindo, vê-se que a imagem de Deus remete ao mesmo estatuto de direito e justiça, só que visto de duas perspectivas. Ou seja, de

do país, ou o luto diante de sua impossibilidade). A aceitação desta hipótese configuraria portanto um anacronismo na análise deste objeto - o sertão - uma vez que projetaria a ideia, falsa, de que a racionalidade abstrata talvez tivesse salvado o país da dominação capitalistaperiférica. Preferimos nos alinhar à tese mais próxima de Roberto Schwarz, para quem esta distância ao capitalismo central, embora determine um futuro sombrio, ao menos garante alguma distância das próprias excrescências ideológicas do sistema e, ressoando Adorno, permitem a própria visão desta racionalidade como um outro. É claro que, para o diagnóstico prático dos destinos do país, este reconhecimento da ideologia como outro pouco ajuda. Mas crê-se que para a crítica do capitalismo como sistema é necessário ir ao fundo da crítica de sua própria racionalidade.

${ }^{62}$ Vemos aqui a raiz da discussão sobre a reversibilidade na obra de Guimarães Rosa. Muito foi dito sobre o assunto, o que impossibilita que tratemos dele em sua plenitude nesta nota. Podemos apontar, no entanto, que a raiz da reversibilidade diz respeito à maneira como os narradores de Rosa se postam frente ao objeto-sertão. Acredita-se que, ao se observar o nascimento de uma dupla perspectiva - a do coronel e do dependente -, fusionadas no arranjo narrativo, afasta-se a hipótese de que este traço da obra rosiana deve seu impulso a interesses metafísicos do autor. O que se vê, em "A hora e a vez de Augusto Matraga”, é a cuidadosa construção da posição do narrador, entrincheirado entre duas perspectivas de impossível conciliação. Este arranjo gera uma instabilidade bastante potente, que, a nosso ver, será explorada em Grande sertão: veredas. 
ambos os lados há o que Franco chamou de 'encarnação do poder' com o qual se pode negociar: do lado sertanejo, há a negociação por espaço, proteção e favores. Do lado do patriarca, em sua posição fantasmática, há o desespero, pois ele mesmo ocupava esta instância. Neste sentido, o desamparo de Nhô Augusto é sintoma de demanda por ação violenta, prerrogativa coronelista, secretadas de um lugar vazio, por onde não circula poder. A construção da ascese de Nhô Augusto se dará deste lugar de uma autoridade sem lugar no fluxo de poder, com a noção de justiça sendo amparada pela referência ao lugar vazio na estrutura coronelista.

A disposição de sua ascese ficará muito clara quando o casal de pretos chama um padre para ouvir a confissão de Nhô Augusto. Nela, nota-se que este significante Deus/justiça - permeia o sentido da confissão. Logo de início, o ex-proprietário pergunta: "será que Deus vai ter pena de mim, com tanta ruindade que fiz, e tendo nas costas tanto pecado mortal?!”. A resposta do padre é reveladora: “Tem, meu filho. Deus mede a espora pela rédea" (S, p.379, grifo meu). A frase pode ser entendida de muitas maneiras; pode, por exemplo, ser compreendida no sentido da ascese, por quão curta é mantida a rédea da vontade. Mas, e mais importante, pode ser vista da perspectiva coronelista, em que espora se transforma em justiça e rédea vira sinônimo de ação. Ou seja, os pecados mortais de Nhô Augusto só vêm à luz no momento em que a rédea da justiça está completamente frouxa (e por isso as esporadas do exproprietário pesam-lhe sobre a consciência). Dito de outro modo, as questões de Deus e arrependimento nem se formariam se Nhô Augusto ocupasse a posição anterior, pois sua ação na manutenção do ciclo de poder coronelista são auto-justificáveis do ponto de vista legal: ou melhor, cada ação do coronel é a ação que põe o direito através de sua intervenção. 
Neste ponto, e com a ajuda do padre, se compreende a estrutura do fantasma de Nhô Augusto: o clérigo diz "Você nunca trabalhou, não é? Pois, agora, por diante, cada dia de Deus você deve trabalhar por três" (S, p.379). Torna-se claro que o exproprietário 'renasce' socialmente no lugar de dependente, posição na qual o trabalho cumpre uma função essencial na relação com Deus/proprietário ${ }^{63}$. Mas Nhô Augusto não ressuscita como dependente, e por isso falamos em estrutura fantasmática: isto porque o fantasma do ex-coronel continua a agir, mesmo que de um lugar vazio. E é precisamente este traço que dá ao trabalho uma modulação ascética, já que, como se disse, do trabalho do ponto de vista dependente não se espera nenhuma recompensa abstrata, como forma de salvação. O trabalho é simplesmente condição, à qual se pode referir a Deus/proprietário no sentido de pequenos ajustes dentro da lógica do favor. A abstração da justiça e da recompensa via penitência só adquirem este caráter ‘puritano' em Nhô Augusto porque ele funciona em outro registro, que é o do fantasma: a saber, a reminiscência da prerrogativa de ação funcionando a partir de um lugar vazio, onde a ação - por não receber o influxo de poder - não adquire qualquer status de justiça. A ação privada de consistência é o que define a angústia de Nhô Augusto; por um lado as ações passadas são vistas, desta perspectiva pós-morte, como condenáveis; por outro, o ímpeto de agir não encontra qualquer sustentação.

É através deste fantasma que Nhô Augusto subverterá a fala do padre para adequá-la a esta estrutura. O padre diz: "Reze e trabalhe, fazendo de conta que esta vida é um dia de capina com sol quente, que às vezes custa muito a passar, mas

\footnotetext{
${ }^{63} \mathrm{O}$ trabalho se relaciona com a justiça de maneira diferente de como se dá esta relação no puritanismo. No caso sertanejo, os frutos do trabalho não são vistos como recompensas divinas, ou um atestado de sua retidão, mensurações palpáveis da relação entre trabalho e Deus. O trabalho se põe como totalidade em relação a Deus, justamente porque o acesso à subsistência pode ser barrado por inteiro. Neste sentido, o pleito junto à justiça divina toma a forma de pedidos pessoalizados para que esta cuide do trabalho com pequenos ajustes, ou como clemência, ação que envolve o trabalho como um todo e mede as ações do trabalhador também em seu aspecto total.
} 
sempre passa. E você ainda pode ter muito pedaço bom de alegria... Cada um tem a sua hora e a sua vez: você há de ter a sua" (S, p.380, grifo meu). Nhô Augusto compreende o conselho à sua maneira, cunhando sua famosa frase: “ - Eu vou p'ra o céu, e vou mesmo, por bem ou por mal!... E minha vez há de chegar... P'ra o céu eu vou, nem que seja a porrete!” (Idem, p.381).

A frase deve ser decerto entendida como resto de autoritarismo em Nhô Augusto. Mas deve-se ter em mente a discussão prévia, na qual a personificação da figura que exerce a justiça, seja Deus ou o proprietário, é a base para a afirmação. Neste sentido, retoma-se o que se disse antes: a novela em sua segunda metade passa a funcionar num registro fantasmático, que encerra uma dupla ordem de consequências aos significantes em jogo. Ou seja, a posição fantasmática de Nhô Augusto condiciona a ideia de trabalho, cara aos dependentes, ao autoritarismo, prerrogativa proprietária. Esta conjunção se desdobra em outra, de importante consequência: a espera por justiça - vista de fora, como dádiva pessoal - ao imperativo da ação justa - ação que ela mesma põe o direito. Isto é, a expectativa pelo momento de justiça, que há de chegar, nem que seja a porrete.

Esta posição fantasmática, situada no coração do sertão, gera um corpo estranho no que antes caracterizamos de 'trabalho total' do sertanejo. Este, como vimos, põe-se como total porque, como trabalho de subsistência, coloca-se em relação direta com a terra. Em resumo, a pressão sobre o trabalho de subsistência e a compressão da dependência na primeira república geram as condições para esta 'totalidade do trabalho'. Nhô Augusto, jogado nesta posição, atua com seu fantasma precisamente neste ponto: diz o narrador que a personagem 
trabalhava que nem afadigado por dinheiro, mas, no feito, não tinha nenhuma ganância e nem se importava com acrescentes: o que vivia era querendo ajudar os outros. Capinava para si e para os vizinhos do seu fogo, no querer de repartir, dando de amor o que possuísse. E só pedia, pois, serviço para fazer, e pouca ou nenhuma conversa ( $\mathrm{S}$, p.382).

O altruísmo de Nhô Augusto deve ser visto como a conjunção da posição de dependente e sua inclinação ao trabalho através do fantasma do patriarca. A posição fantasmática retira da autoridade de Nhô Augusto o sentido jurídico de suas ações, gerando uma situação que, formalmente, é quase idêntica à do sertanejo pressionado pelos arranjos coronelistas: a saber, o sertanejo que trabalha tendo diante de si um abismo de sentido, pois toda sua produção ou acontece num vazio monetário ou é prontamente espoliada. $\mathrm{O}$ ato de trabalho, neste sentido, está constantemente à mercê de um corte que o coloca diante de um vazio. O mesmo acontece com Nhô Augusto e sua busca por penitência: cada uma de suas ações tem de se haver com uma falta de justiça e com um desamparo, pois a vontade coronelista gira em falso sem movimentar nenhum poder. Da mesma forma, seu trabalho ganha contornos obsessivos pois a dívida que Nhô Augusto deve pagar aponta para esta falta, já que todos os seus pecados anteriores serviam como corte na vida sertaneja e agora, vistos desta perspectiva, são ações sem nenhuma base jurídica. A bem da verdade, o que a dívida impagável de Nhô Augusto demonstra é precisamente a comunicação de uma falta no sistema coronelista, o que o coloca em posição de identificação com o sertanejo à beira do corte.

Vejamos o grafo abaixo, que ajuda na visualização da perspectiva narrativa: 


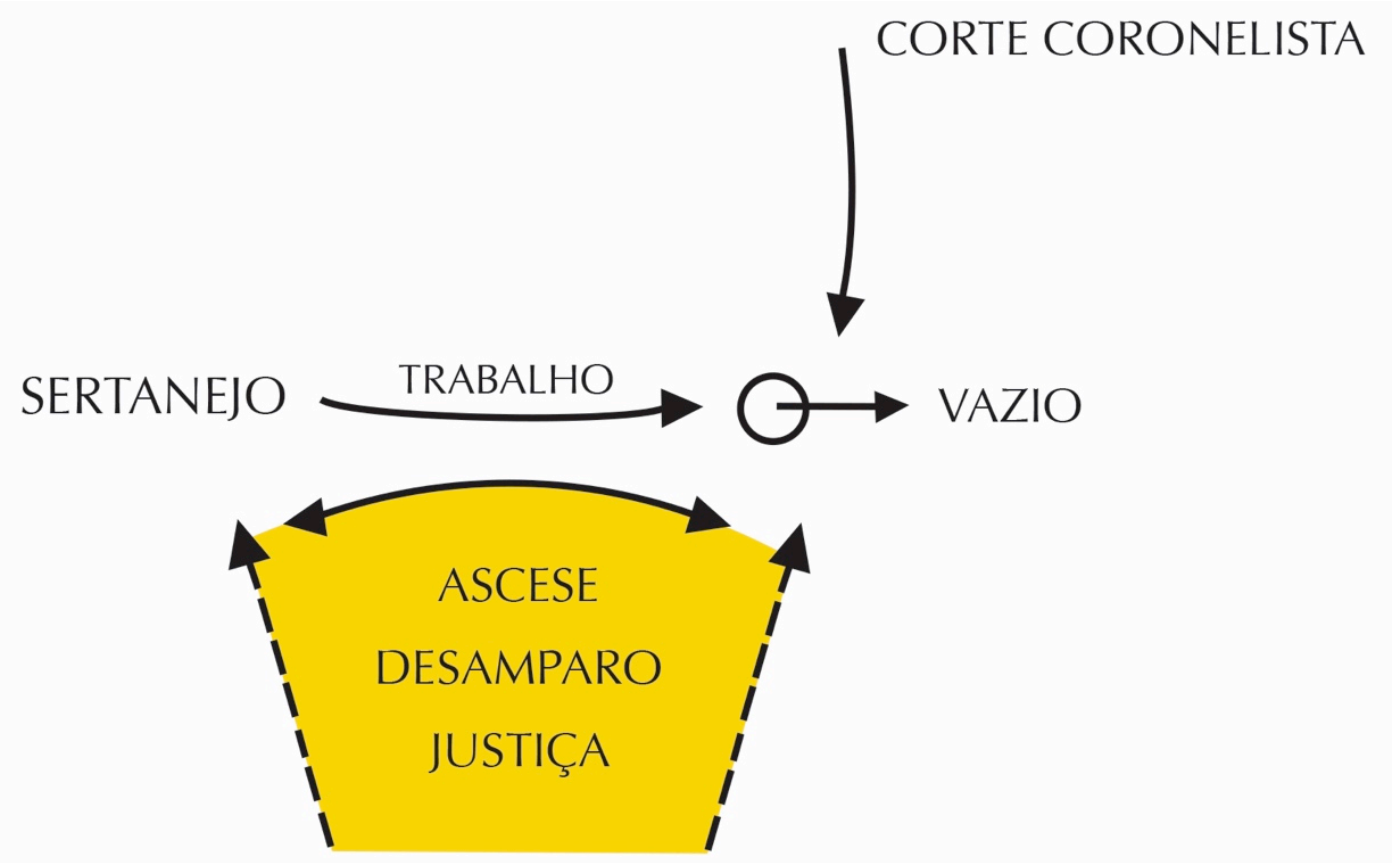

(PERSPECTIVA)

FANTASMA

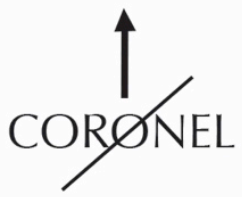

O grafo ajuda no entendimento da perspectiva da novela após a morte social de Nhô Augusto. A posição coronelista, barrada, gera o fantasma e é deste ponto que se tem a perspectiva narrativa. As ações do fantasma, privadas de sentido, necessariamente apontam para o ponto de corte no trabalho sertanejo, ao mesmo tempo em que se remetem ao trabalho de subsistência como referência para a construção deste pêndulo (que oscila entre o vazio e o trabalho), que irá configurar as noções de ascese, desamparo e justiça. Importante dizer que todas estas construções se dão em negativo, e este é um dado fundamental para a hagiografia da novela: sua negatividade é realçada quando se pensa em hagiografias tradicionais, em que há um 'chamado' ao 
bem. No caso de Nhô Augusto, como tentamos demonstrar, seu chamado está necessariamente ligado à posição do fantasma advindo de sua morte social: isto é, das prerrogativas coronelistas que demandam a conjunção de três fatores. Eles são: a ação interventora, a constituição de justiça através das ações, e a comunicação de um conteúdo através da conjunção dos dois primeiros. No caso coronelista, o que se comunica é o poder. Já no caso do fantasma, do coronel barrado, o imperativo da ação, ao ligar-se a um vazio de sentido, acaba comunicando o desamparo de Nhô Augusto e o imperativo de salvação. A conjunção fantasmática destes fatores é o que é plasmado em sua fórmula hagiográfica conhecida - ir ao céu, nem que seja a porrete.

A oscilação deste pêndulo que constitui a ascese e comunica a falta acaba por criar uma identificação com a posição sertaneja no ponto de corte e Nhô Augusto. Esta identificação será de suma importância para a identificação enigmática da novela $($ Nhô Augusto $=$ Augusto Matraga $)$. Antes de irmos a ela, no entanto, é preciso chegar à figura do jagunço desta vez vista da perspectiva sertaneja. O jagunço, como se disse, tem sua função estreitamente vinculada aos nexos de sentido entre o direito à terra e a produção coronelista. Sobre o primeiro, pode-se dizer que este estatuto da terra na primeira república encerra uma situação de volatilidade que é estruturalmente ligada ao funcionamento do coronelismo como sistema. O uso da terra pelos dependentes, por assim dizer, está à espera da intervenção do coronel: sentida como um corte, esta intervenção pressiona os arranjos de dependência, seja expulsando o sertanejo para os fundos do sertão, seja confiscando a produção de subsistência, seja liberando-o como mão-de-obra num vácuo salarial. Aqui vemos o entrelaçamento das noções de propriedade, direito e autoridade, pois o dependente que ocupa diretamente a terra põe-se sob a jurisdição do proprietário; este porém $f a z$ o direito na medida em que se 
coloca como interventor e expande seus negócios coronelistas, arrebanhando mais terras e mais dependentes.

Este estado de coisas gera uma situação sui generis do ponto de vista jurídico, pois a relação direta entre subsistência e terra aponta para o que Franco já havia dito sobre a sociedade caipira do século XIX: a saber, da ausência de uma instância jurídica abstrata nasce uma ideia pessoalizada de direito; isto é,

a dimensão de homem [do sertanejo] chega-lhe, assim, estritamente como subjetividade. Através desta pura e direta apreensão de si mesmo como pessoa [...] define-se o caráter irredutivel das tensões geradas. A visão de si mesmo e do adversário como homens integrais impede que desavenças sejam conduzidas para lutas parciais, mas faz com que tendam a transformar-se em lutas de extermínio (FRANCO, 1997, p.62, grifos meus).

A situação sofre um deslocamento significativo quando este mundo do sertão começa a se movimentar diante dos arranjos coronelistas. Se é possível afirmar que pouco teria mudado do ponto de vista prático - a saber, não haveria qualquer noção de direito abstrato que mediasse essas disputas - há na primeira república uma noção de direito que estratifica essas lutas de extermínio. Quando o proprietário, ao ocupar a posição coronelista, transforma-se numa instituição que necessita intervir precisamente no uso da terra pelos sertanejos, a noção de homem integral, constituída pelo uso da terra para subsistência, tem agora de se haver com uma ideia de justiça também estratificada. Em outras palavras, como já se comentou no caso de "Duelo", há uma justiça entre sertanejos que obedece ao esquema de Franco - isto é, ao embate pessoa versus pessoa, que deve ser resolvido nos interstícios do sertão; e o embate entre jagunços e sertanejos, no qual a noção de homem integral esbarra numa 
impossibilidade. Franco, em seu estudo do século XIX, já aventara a esta estrutura quando chamou a atenção ao descompasso entre interesses econômicos dos proprietários indo de encontro ao tecido de lealdade que compunha a dependência. $\mathrm{O}$ arranjo da primeira república, no entanto, é mais complexo e depende da institucionalização de mecanismos de pressão e intervenção nas relações de dependência. É neste ponto que o sertanejo se depara com a máquina coronelista, que se vincula a outras demandas econômicas e de poder que em muito escapam do escopo sertanejo. O choque, neste caso, entre a noção de homem integral com esta instância de corte é muito mais brutal, e gera um sentido de desamparo jurídico que também é muito mais agudo.

Esta relação entre a integralidade do homem e desamparo ganha novos tons quando o casal de pretos e Nhô Augusto se muda para os fundos do sertão, no povoado do Tombador. Trata-se de um lugar em que a história pregressa de Nhô Augusto seria mais facilmente esquecida e, mais importante, um local em que a angústia jurídica do ex-proprietário encontraria ajuste na posição de sertanejo, isto é, via trabalho: mais importante, no entanto, é que a noção de trabalho para Nhô Augusto é adaptada a esta mudança à beirada do sertão, onde o sistema coronelista, ainda que presente, é menos potente. Este posicionamento na franja do sertão possibilita que o fantasma do coronel pouco a pouco se acomode à situação sertaneja: a saber, seu exercício ascético se transfigura na constituição da imagem de homem integral através do trabalho: por isso, Nhô Augusto "não fumava mais, não bebia, não olhava para o bom-parecer das mulheres, falava junto em discussão" (S, p.382). Em outras palavras, o exercício de ascese foca-se de um lado no trabalho, de outro na expressão de qualquer desejo que pudesse gerar conflito e, desta forma, abrir um vazio jurídico em sua frente, no qual a ação fosse a balança e a medida da justiça. 
No entanto, como afirma o narrador, "como tudo é muito pequeno, e o sertão ainda é menor" (Idem, p.383), Nhô Augusto dá de encontro com um velho conhecido - Tião da Thereza - que passava pela região à busca de reses perdidas num estouro de boiada. O conhecido se espanta ao ver o ex-proprietário vivo e logo lhe dá as notícias de sua vida pregressa: sua mulher, Dona Dionóra, continuava amigada com seu Ovídio, pensando em casamento por imaginar ser viúva. Já a filha "crescera sã e se encorpara uma mocinha muito linda, mas tinha caído na vida, seduzida por um cometa, que a levara do arraial, para onde não se sabia...” (Idem, p.384). Já o Major Consilva, este agiu de acordo com o roteiro coronelista: mandando no Murici depois de arrematar as duas fazendas de Nhô Augusto. A pior notícia, no entanto, dizia respeito a Quim Recadeiro: este fora defender o ex-patrão e levara mais de vinte balas dos capangas do Major.

Às notícias, Nhô Augusto reage de modo a definir o desfecho da novela: ele pede a Tião que não lhe conte mais nada de sua vida pregressa:

Só te peço é para fazer de conta que não me viu, e não contar p'ra ninguém, pelo amor de Deus, por amor de sua mulher, de seus filhos e de tudo o que para você tem valor!... Não é mentira muita, porque é a mesma coisa em como se eu tivesse morrido mesmo... Não tem mais nenhum Nhô Augusto Estêves, das Pindaibas, Tião... (S, p.384, grifos meus).

As notícias e a assunção de sua morte geram um deslocamento no fantasma de Nhô Augusto. Incapaz de espantar a tristeza através de seu esquema original, os pensamentos de vingança voltam a habitá-lo, "uma vontade doente de fazer coisas mal-feitas, uma vontade sem calor no corpo, só pensada: como que, se bebesse e 
cigarrasse, e ficasse sem trabalhar nem rezar, haveria de recuperar sua força de homem e acerto de outro tempo" (S, p.385). Mas as notícias conformam uma morte consumada, da qual não se pode voltar; por isso Nhô Augusto aceita o conselho de sua mãe preta de que o melhor era "trabalhar mais e escorar firme, para poder alcançar o reino-do-céu" (Idem, Ibidem).

Este novo posicionamento de Nhô Augusto, com a morte consumada e a impossibilidade de voltar à velha vida, aproxima ainda mais seu fantasma da posição do sertanejo e desloca sua ascese à própria equação homem integral = trabalho total . O fantasma de Nhô Augusto entra finalmente, por assim dizer, no mesmo eixo do sertanejo, e faz caducar as prerrogativas de vingança esperada por um coronel. Como consequência imediata deste realinhamento, a perspectiva narrativa se desloca para a perspectiva do sertanejo à medida que o próprio Nhô Augusto se coloca ali. A personagem se ajusta àquela vida e deixa cair as prerrogativas ascéticas de antes:

Até que, pouco a pouco, devagarinho, imperceptível, alguma cousa pegou a querer voltar para ele, a crescer-lhe do fundo para fora, sorrateira como a chegada do tempo das águas, que vinha vindo paralela: com o calor dos dias aumentando, e os dias cada vez maiores, e o joão-de-barro construindo casa nova, e as sementinhas, que hibernavam na poeira, esperando na poeira, em misteriosas incubações. Nhô Augusto agora tinha muita fome e muito sono. $\mathrm{O}$ trabalho entusiasmava e era leve. Não tinha precisão de enxotar as tristezas. Não pensava nada... (S, p.387, grifos meus).

O fantasma do coronel se alinha à perspectiva sertaneja, o que muda o caráter de sua ação. Esta ação, agora caminhando sobre a linha do trabalho total, enquanto ação fantasmática, continua apontando para o vazio e para o ponto de corte da mesma 
perspectiva sertaneja. Não por acaso, portanto, o próximo encontro de Nhô Augusto será com os jagunços.

O deslocamento da perspectiva da novela, do coronel barrado à perspectiva sertaneja, promove consequências nas ações de Nhô Augusto. Estas ações continuam carregando um vazio e uma pergunta quanto à justiça e a salvação (portanto é correto dizer que a identificação de Nhô Augusto à posição dependente nunca é completada, pois o fantasma do coronelismo nunca o abandona e serve como mediação de suas ações). Mas elas abdicam do caráter ascético anterior, como mostra o narrador:

E, uma vez, manhã, Nhô Augusto acordou sem saber por que era que ele estava com muita vontade de ficar o dia inteiro deitado, e achando, ao mesmo tempo, muito bom se levantar. Então, depois do café, saiu para a horta cheirosa, cheia de passarinhos e de verdes, e fez uma descoberta: por que não pitava?!... Não era pecado... Devia ficar alegre, sempre alegre, e esse era um gosto inocente, que ajudava a gente a se alegrar... (S, p.388, grifo meu).

A transformação no espírito de Nhô Augusto deve ser atribuída ao significante do trabalho no mundo sertanejo. Como já se disse, ao ocupar sua posição anterior, comunicando uma falta através de sua ascese, Nhô Augusto se aproxima do dependente. A afirmação pode parecer paradoxal, pois fala-se de trabalho precisamente no momento em que o ex-proprietário abre mão das prerrogativas ascéticas que realçavam o trabalho e se acomoda nesta posição 'caipira', em que a disciplina laboral é uma entidade estranha. 
Nos capítulos anteriores já tratamos da questão da labilidade em sua relação com o trabalho abstrato. $\mathrm{O}$ assunto é complexo, mas incide no ponto em que aqui insistimos: a fantasmagoria do trabalho sertanejo ${ }^{64}$. Sua conceituação é difícil pois, vista em si e desconecta das demais instâncias de trabalho com que se vincula, a amorfia do trabalho sertanejo aparece como indisciplina. Esta conceituação é imprecisa, todavia, pois, numa palavra, desconsidera o teor de falta ou alienação que é comunicado ao trabalho sertanejo. A saber: no trabalho capitalista-industrial, esta falta é comunicada por seu caráter abstrato, isto é, pelo compensação em moeda pelas horas de trabalho. Ou seja, grosso modo, a alienação do trabalho numa sociedade industrial circula através da própria possibilidade de sua abstração em dinheiro: uma vez que é através da moeda que o trabalhador comunicará sua desconexão com os meios de produção ao necessitar comprar os itens de subsistência. Neste sentido, a própria ideia de disciplina laboral é a forma como a alienação se comunica na sociedade industrial.

No sertão, o caso é outro. Em "A hora e a vez de Augusto Matraga", cria-se uma situação peculiar em que a morte social do proprietário joga-o em choque com a perspectiva sertaneja. Ao constituir um fantasma de sua antiga posição, como vimos, forja-se uma imagem do trabalho disciplinado menos em função do que ele significa numa sociedade industrial constituída e mais pela própria estrutura de poder coronelista. Dito de outro modo, o trabalho de Nhô Augusto figura como disciplinado apenas por comunicar uma falta, que neste caso diz respeito ao barramento do fluxo de poder coronelista. Trabalho e poder, no entanto, coincidem por um motivo que

\footnotetext{
${ }^{64}$ Ver o artigo já mencionado, "O vaqueiro e o procurador dos pobres: Vidas secas", de Ana Paula Pacheco. O texto aponta para esta contradição nos escritos pós-1930: como o trabalho pode ser uma entidade fantasmática e mesmo assim assumir o caráter de totalidade, reinando sobre a vida do sertanejo. Procuramos mostrar como este paradoxo se vincula às movimentações político-econômicas do sertão após a abolição da escravatura, condição produtiva que determina os rumos da industrialização brasileira.
} 
também é estrutural: a saber, porque o capitalismo da Primeira República funciona a despeito, e mesmo em função, do vácuo abstrato (e aqui o vazio da abstração do trabalho e do direito coincidem). Deste modo, a visão do coronelismo como sistema ajuda na compreensão do entrelaçamento entre trabalho e direito. Vejamos o gráfico abaixo:

\section{ACUMULAÇÃO CAFEEIRA}

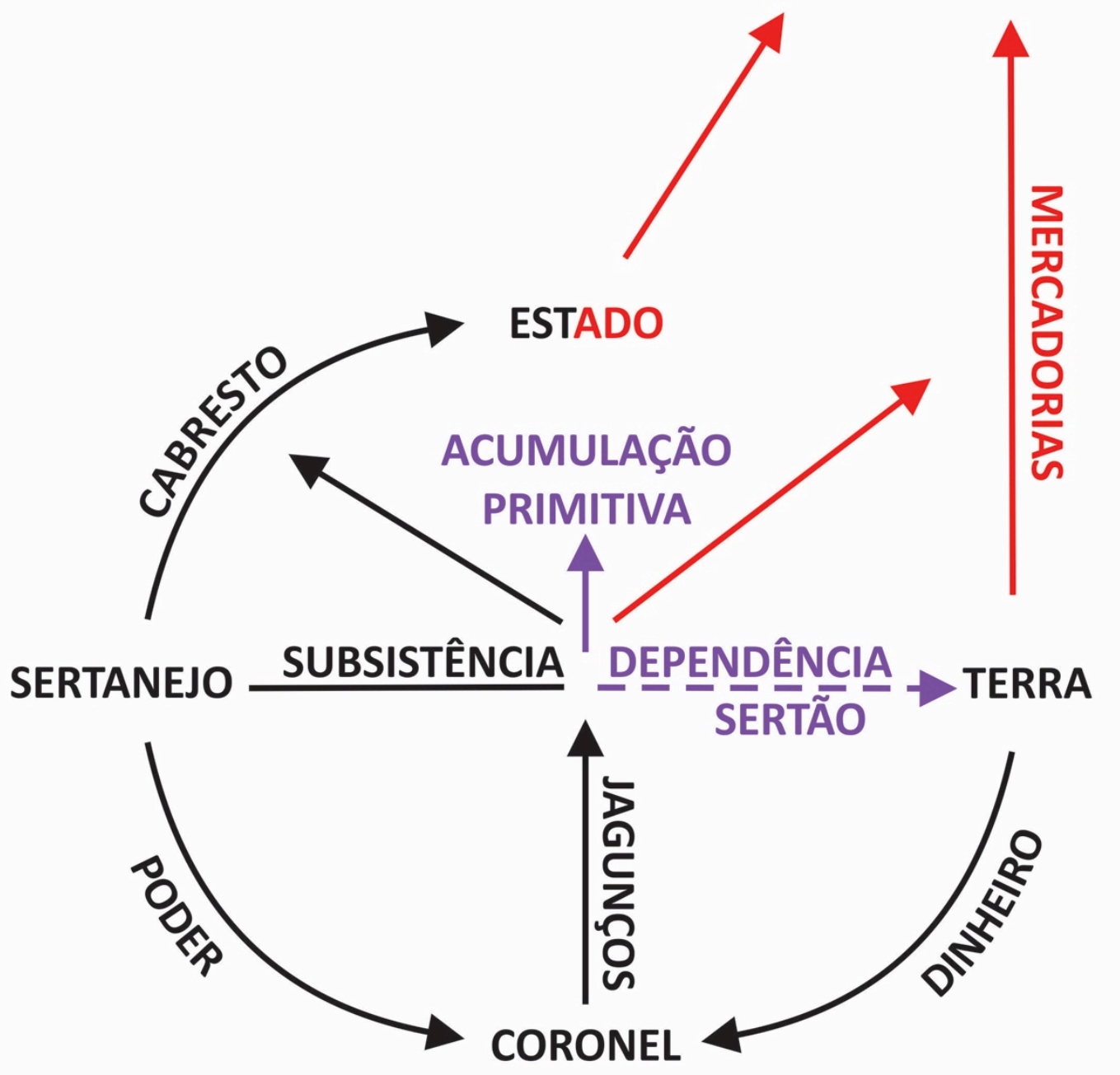


A metade inferior do grafo demonstra precisamente o local onde se dá a ação em "A hora e a vez de Augusto Matraga”. A saber, ela acontece no ponto de concentração e circulação do poder coronelista, que se liga ao esquema mais amplo de acumulação da primeira república. Note-se que a ação do coronel, através dos jagunços, configura o ponto de corte que comunica a alienação a todo o sistema, pois gera a base para o poder político do coronel (votos de cabresto) e seu poder econômico (a produção de mercadorias para o mercado interno). É neste ponto de corte, no entanto, que se criam como subprodutos a dependência a que se sujeita o sertanejo bem como a própria ideia de sertão como objeto.

Como o argumento de Maria Sylvia Franco demonstra, a relação de poder entre dependentes e proprietários acontece neste local em que, da parte do coronel, o direito é totalmente pessoal e de impossível abstração. As cores no grafo acima nos ajudam na compreensão do argumento: o preto diz respeito à circulação de poder no interior do coronelismo; o vermelho, sua ligação com a acumulação cafeeira e o mercado capitalista externo; já o roxo, este é o ponto onde a novela tece sua trama, pois trata-se do local em que a acumulação primitiva ocorre quando o direito do proprietário se consolida no ato de obstar o trabalho sertanejo. O fantasma de Nhô Augusto, portanto, ao secretar uma falta de poder e aproximar-se da posição sertaneja, acaba criando uma imagem deste ponto vazio em que a subsistência será interrompida.

Por este motivo é de interesse observar a alocação do fantasma de Nhô Augusto na mesma linha de ação do sertanejo; e aqui cabe uma palavra à caracterização deste fantasma: como tentamos demonstrar, este secretava uma falta pois era a figura do coronel barrado, retirado da circulação de poder. Ao ser jogado na condição de sertanejo, esta falta se traduz em trabalho total pois é esta a imagem 
limite que conjuga o sertanejo à sua própria falta. Todavia, a partir do momento em que a perspectiva narrativa se desloca para o eixo do sertanejo, a secreção desta falta também muda de perspectiva, o que, por sua vez, opera uma mudança de perspectiva geral na novela: em poucas palavras, a novela desloca-se da posição do coronel à posição do dependente.

Ela passa a ver, agora do ponto de vista sertanejo, como se dá a alienação $a$ partir do coronel: como que, após caminhar sobre o eixo da subsistência sertaneja, Nhô Augusto atravessasse o ponto do corte e passasse a mirar o processo da perspectiva do sertão. E neste caso, de maneira muito importante, o ímpeto para a ação jungido ao vazio jurídico fá-lo olhar novamente para o coronel, mas agora através dos jagunços. Trocando em miúdos, depois de todo seu périplo, Nhô Augusto se vê do outro lado do espectro, pronto para juntar-se à roda coronelista novamente, desta vez como jagunço.

Que o fantasma continua a atuar é muito claro, pois a demanda de ação, prerrogativa do coronel, é percebida neste flerte com o jaguncismo. Quando o grupo de Joãozinho Bem-Bem chega ao vilarejo, "vindos do norte, da fronteira velha-deguerra, bem montados, bem enroupados, bem apessoados, [...] o povo do vilarejo não se mexia, apavorado, com medo de fechar as portas, com medo de ficar na rua, com medo de falar e de ficar calado, com medo de existir" (S, p.389). Nhô Augusto, no entanto, é o único que mostra contentamento e deslumbre com a chegada dos jagunços. Ele corre ao encontro dos capangas, lhes oferece pouso e mostra interesse por seus assuntos.

Joãozinho Bem-Bem, então, conta a Nhô Augusto que "estava de passagem, com uma pequena parte de seu bando, para o sul, para o arraial das Taquaras $[\ldots] a$ chamado de seu amigo Nicolau Cardoso, atacado por um mandão fazendeiro, de 
injustiça” (Idem, p.391, grifo meu). A declaração é clara em seu conteúdo, e corrobora com o que já dissemos sobre os grupos jagunços da Primeira República. A aliança destes se dá com os fazendeiros, e sua ação é necessária para a circulação de poder e, sobretudo, pela afirmação da consistência do direito do coronel. Neste sentido, a menção à injustiça ao fazendeiro aliado é fundamental, pois indica a habitação da inconsistência jurídica na contenda. O papel dos jagunços é portanto o de, no ato mesmo de intervenção, selar o direito à circulação de poder do proprietário Nicolau Cardoso, e ao mesmo tempo, e pelo mesmo ato, comunicar uma falta ao erradicar seu adversário. Esta falta, nota-se, é o que move a acumulação primitiva e não só sustenta o coronelismo como vincula-a à acumulação cafeeira, pois é a partir desta movimentação política que o coronel pode expandir sua base de votos, barganhar crédito e escorar a produção. Na medida em que a ação dos jagunços abre um rasgo sobre o direito de propriedade do contestante, alterando todos os arranjos de dependência ali firmados, o corte traz no bojo o nó górdio do sistema políticoeconômico da primeira república, em que direito à propriedade e produção ligam-se à violência e alienação.

No momento em que o fantasma de Nhô Augusto se alinha aos vetores de dependência, o mesmo ímpeto de ação que apontava para o corte coronelista, o local de vazio jurídico, transforma-o num potencial jagunço. Este movimento diz muito sobre a perspectiva narrativa da novela, que como demonstramos, paulatinamente se desloca alinhando-se à perspectiva sertaneja para, quando isto acontece, ultrapassá-la, graças à ação do fantasma, em direção à jagunçagem. Abaixo esquematizo o curso perspectivo da novela, para melhor entendimento: 


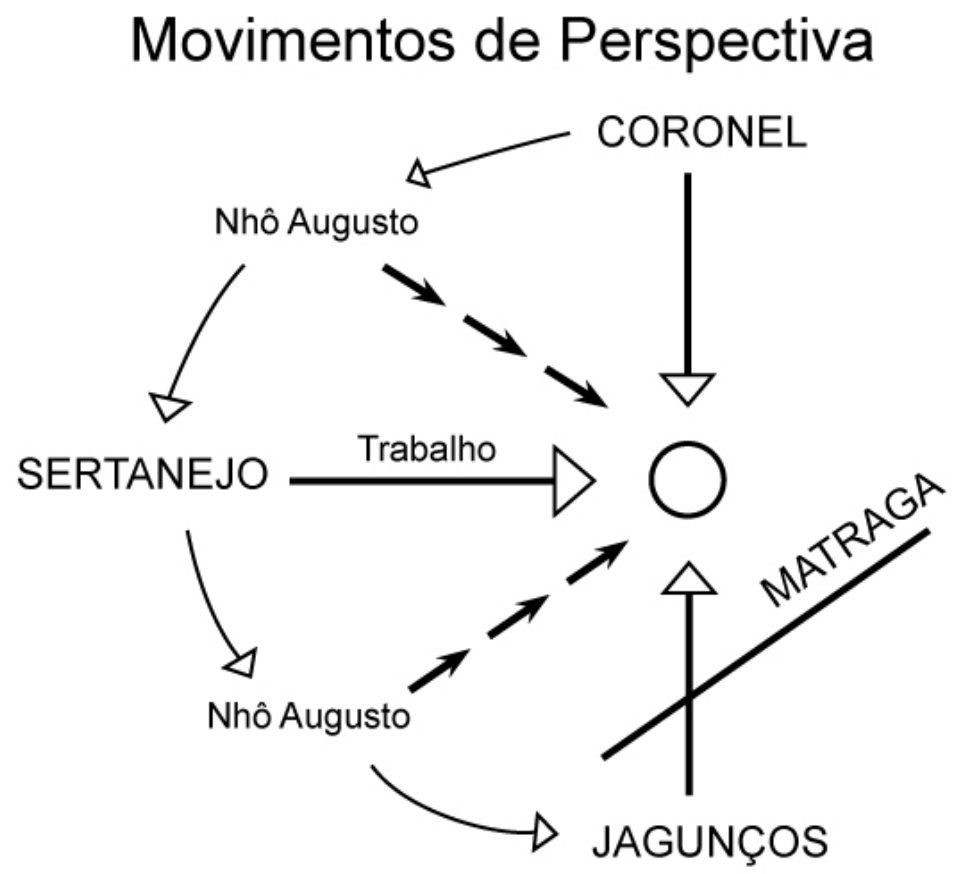

Quando o fantasma de Nhô Augusto age sobre a perspectiva sertaneja, a personagem é coloca em direto contato com a ambiguidade que caracteriza a jagunçagem, que encontra efetividade no atravessamento das perspectivas exploradas na novela: coronel e sertanejo. Noutras palavras, os grupos jagunços encontravam função precisamente na linha de corte do coronel ao sertanejo, pois nela afirmavam sua aliança à lógica coronelista ao comunicar a alienação às duas pontas do sistema.

A ambiguidade da posição de Nhô Augusto, que habita o local de coronel barrado e sertanejo, é logo percebida por Joãozinho Bem-Bem, que lhe diz:

- O senhor, mano velho, a modo e coisa que é assim meio diferente, mas eu estou the prestando atenção, este tempo todo, e agora eu acho, pesado e pago, que o senhor é mas é pessoa boa mesmo, por ser. Nossos anjos-da-guarda combinaram, e isso para mim é o sinal que serve. A pois, se precisar de alguma coisa, de tem um recado ruim para mandar para alguém... Tiver algum inimigo alegre, por aí, é só dizer o nome e onde mora (S, p.395-396). 
A mensagem, muito clara, insinua um laço de lealdade entre Bem-Bem e Nhô Augusto que poderia recolocá-lo no jogo coronelista. Diante da recusa de Nhô Augusto, o jagunço faz uma oferta ainda mais explícita:

- Mano velho, o senhor gosta de brigar, e entende. Está-se vendo que não viveu sempre aqui nesta grota, capinando roça e cortando lenha... Não quero especular coisa de sua vida p'ra trás, nem se está se escondendo de algum crime. Mas, comigo é que o senhor havia de dar sorte! Quer se amadrinhar com meu povo? Quer vir junto? (S, p.396)

Nhô Augusto rejeita a proposta novamente e vê o bando de Joãozinho Bem-Bem partir. O sentido desta recusa deve ser o foco de atenção de análise, pois é ela que determina o fecho da estória. Como se disse, ambos os convites colocariam Nhô Augusto no interior da circulação coronelista de poder, fosse na posição de mandante de um crime, fosse como próprio membro do grupo de Bem-Bem. Esta negação deve portanto ligar-se à primeira frase da novela: "Matraga não é Matraga, não é nada", dado que a virada hagiográfica da novela deve se haver com uma posição vazia dentro do universo coronelista. Isto porque o termo Matraga só poderá ligar-se a Augusto no momento em que sua trajetória hagiográfica se completar; e, neste momento, torna-se claro que a completude desta ação tem duas faces: a satisfação dos impulsos autoritários de Nhô Augusto e o alinhamento à posição dependente, uma conjunção socialmente impossível, mas literariamente trabalhada como forma e perspectiva.

Quando a negação se desenrola em "Matraga é Estêves. Augusto Estêves, filho do Coronel Afonsão Estêves..." e toda a narrativa toma lugar dentro do contexto coronelista, evidencia-se que a virada hagiográfica vincula-se à trajetória de Nhô 
Augusto neste universo, mas seu conteúdo não é de uma ascese pessoal. Isto se dá porque o barramento de sua posição coronelista desloca a ascese para um não-lugar dentro daquele universo, de modo que seus impulsos acabam por apontar para um lugar vazio. Este lugar, como vimos, é o próprio ponto que faz o poder circular no sertão - a saber, o ponto do corte coronelista. Numa palavra, dir-se-ia que a novela expõe todo o contexto sertanejo para que a virada hagiográfica extraia seu conteúdo de sua própria subversão: como se toda a ascese de Nhô Augusto estivesse à espera do momento em que o corte ocorre e toda a ciranda coronelista é posta em movimento, para enfim barrá-la, como que dobrando a totalidade funcional do sistema sobre este furo, oco de sentido. O barramento, por fim, ao mesmo tempo em que termina de expor o sistema coronelista, tensiona-o precisamente sobre seu ponto vazio.

$\mathrm{O}$ argumento torna-se mais tangível quando nos dirigimos ao conteúdo manifesto da novela. Logo após o primeiro encontro com o grupo de Bem-Bem, Nhô Augusto decide partir do povoado onde estava, abandona seus pais pretos e segue num jumento, vagando pelo sertão. A viagem é sem destino pois, sabe-se, esta pulsão direciona-se a um vazio. E Nhô Augusto o encontra ao cruzar novamente com o bando jagunço, desta vez rumando à Bahia. Quando sabe da notícia, Nhô Augusto mostra contentamento e assegura-se de que é este evento que dará sentido à sua trajetória: “Agora sim! Cantou p'ra mim, passarim!...” (S, p.404).

Joãozinho Bem-Bem também se alegra ao ver o companheiro, e lhe conta as notícias:

- É isso, mano velho... Livrei meu compadre Nicolau Cardoso, bom homem... E agora vou juntar o resto do meu pessoal, porque tive recado de que a política se apostemou, do lado de lá das divisas, e estou indo de rota batida para o Pilão Arcado, que o meu Franquilim de Albuquerque é capaz de precisar de mim... 
Nota-se que as notícias da 'alta política', tudo conforme com sua funcionalidade, contrastam com o vagar de Nhô Augusto no jumento: pois é a atividade dos jagunços que, no fundo, delimita os espaços do sertão. Aqui se cria um senso de dualidade que será muito importante para o desenvolvimento de Grande sertão: veredas: o de vastidão do sertão versus sua estreiteza. Para Joãozinho Bem-Bem, o mundo é pequeno - "Está vendo, mano velho? Quem é que não se encontra, neste mundo?" pois é ele mesmo quem faz as fronteiras do sertão, da mesma forma como serve de navalha que tece acordos.

A amplidão que acompanha a ascese de Nhô Augusto, colocada ao lado da atividade cerceadora de Bem-Bem: é este o efeito de hagiografia que, neste momento da novela, enche-se de potencial. É também esta a noção de sertão que advém deste efeito e prepara o caminho para o Grande sertão: o universo sertanejo inteiro dobrando-se sobre um vazio. Os impulsos de Nhô Augusto nunca deixaram de apontar para este ponto, e no segundo encontro com Joãozinho Bem-Bem a oportunidade para efetivamente atuar sobre este não-lugar do sertão, que é o que o define, se lhe mostra.

A situação, como se poderia esperar, tem a ver com a ação dos jagunços num ato que institui e dá consistência ao direito (o que antes chamamos de prerrogativa coronelista). Um sertanejo matara um membro do grupo de Bem-Bem: o ato que garante o direito do grupo é precisamente a intervenção, ou seja, a garantia de que o monopólio da intervenção violenta está do lado dos jagunços. Por isto, o chefe jagunço afirma: não obstante o assassino tenha caído no mundo, fugido, sua família deve "pagar tudo, direito!" (S, p.406). Neste instante, Joãozinho Bem-Bem faz a terceira oferta a Nhô Augusto para que este se junte ao grupo, no lugar do membro 
falecido. Nhô Augusto acaricia sua arma, "do jeito com que um gato poria a pata num passarinho" (Idem, p.407). Neste momento, a estrutura fantasmática tem novamente a chance de posicionar seus impulsos na feitura da lei: a saber, do lado da violência que intervém para definir os limites do sertão.

A ascese de Nhô Augusto, sua transformação em Matraga, não teria sentido se esta fosse sua escolha: nesta altura, a narrativa mostra todo seu poder de construção, pois a trajetória de queda e realinhamento de Nhô Augusto ganha total visibilidade quando a perspectiva dos jagunços é confrontada à dos sertanejos, aos olhos de Nhô Augusto. Quando o pai do homem que matou Juruminho, homem de Bem-Bem, vem pedir clemência, torna-se claro o sentido de corte a que a força de Nhô Augusto é convidada a participar: " - Ai, meu senhor que manda em todos... Ai, seu Joãozinho Bem-Bem, tem pena!.. Tem pena do meu povinho miúdo..." (S, p.407, grifo meu). Neste ponto também toma forma o significante de Deus para os sertanejos, em direta relação com a intervenção coronelista: "O senhor é poderoso, é dono do choro dos outros... Mas a Virgem Santíssima lhe dará o pago por não pisar em formiguinha do chão” (Idem, p.408, grifos meus).

Joãozinho Bem-Bem responde ao velho como lhe é esperado: "Lhe atender não posso, e com o senhor não quero nada, velho. É a regra... Senão, até quem é mais que havia de querer obedecer a um homem que não vinga gente sua, morta de traição?... É a regra" (Idem, Ibidem, grifos meus). Aqui se mostra o contraste entre amplidão e estreiteza, Deus como significante de clemência perante o vazio e a própria mão que faz a lei, para quem Deus é uma entidade que se encontra para aquém de seu próprio gesto. Não há portanto comunicação entre a lei e o dependente, como se poderia esperar de um universo em que não há abstração do direito. Os contornos deste contraste são os próprios contornos da ascese de Nhô Augusto: 
contornos que, ao mesmo tempo em que denunciam sua dupla perspectiva, ensejamlhe o local onde deve direcionar sua ação para completá-la em sua duplicidade; isto é, uma ação que aponta, concomitantemente, para a totalidade da lei e de todo o universo de cesuras e costuras políticas do sertão; e para sua descontinuação, lócus onde a lei é barrada.

Quando Nhô Augusto faz o apelo ao amigo Bem-Bem, dizendo-lhe que "o que o desgraçado do velho está pedindo em nome de Nosso Senhor e da Virgem Maria! E o que vocês estão querendo fazer em casa dele é coisa que nem Deus não manda e nem o diabo não faz" (S, p.409), Nhô Augusto intervém operando uma união de perspectivas impossível: a do sertanejo e seu sentido de Deus, e a do jagunço, em seu sentido de intervenção da lei. Esta união gera um senso de justiça não porque carrega um sentido ético em si, mas porque funciona dentro de toda a construção da dupla perspectiva da novela, de modo que a ação de Nhô Augusto se mostre como um outro da justiça jagunça. Noutras palavras, menos do que um cavaleiro com alta moral, Nhô Augusto encontra um lugar para que sua estrutura fantasmática - que demanda intervenção - aja precisamente no ponto em que não só uma injustiça seja questionada, mas todo o sistema coronelista seja colocado em xeque. É decerto a este último sentido totalizante que a resposta de Bem-Bem se dirige, quando afirma: "Você está caçoando com a gente, mano velho? [...]/ Pois pedido nenhum desse atrevimento eu até hoje nunca que ouvi nem atendi!..." (Idem, Ibidem, grifo meu).

O sinal do duplo pertencimento de Nhô Augusto - dentro e fora do círculo coronelista - é o que marca sua resposta: "Pois então... - e Nhô Augusto riu, como quem vai contar uma grande anedota - ... Pois então, meu amigo seu Joãozinho BemBem, é fácil... Mas tem que passar primeiro por riba de eu defunto..." (Idem, Ibidem, grifo meu). Nhô Augusto coloca-se como homem total, dentro da prerrogativa 
sertaneja, mas para exercer um barramento desta, ao impedir que Bem-Bem se encarregue do cumprimento da lei. Por este motivo a hagiografia tem que se dar num solo negativo - Matraga não é Matraga, não é nada. Porque, em termos de conteúdo, a ascese não revela nada: ela revela somente o impulso de Nhô Augusto agindo como interrupção.

O abraço mortal, que acaba tanto com Bem-Bem quanto Nhô Augusto, transforma o último em Augusto Matraga. Mas, de fato, Matraga não é nada na medida em que não transforma nem depõe o sistema jagunço: Nhô Augusto morre perdoando Dionóra e dando benção a sua filha, como se esperaria de um coronel. Todavia, Matraga acaba significando a posição dependente - o homem total servindo como suporte de um outro, quando este o atravessa e gera como efeito a visão do barramento do sistema coronelista. É este sentido da ascese de Nhô Augusto que deve ser retido: quando este outro surge sobre o próprio corpo moribundo de Matraga, o que se vê é uma visão do objeto-sertão autônomo, visto como é, amarrado a todas as roldanas de poder que "A hora e a vez de Augusto Matraga" tratou de mostrar, mas ao mesmo tempo atravessado por um sentido de justiça que não lhe pertence.

Este sentido outro de justiça é o grande efeito estético da novela, justamente porque se encarrega de entregar o objeto-sertão em sua totalidade: o sistema coronelista, no qual a inserção no capitalismo significa a comunicação de alienação através da relação entre coronéis, dependentes e jagunços. Mas este sistema, transfigurado em forma, apresenta-se flechado por um corpo estranho, que subverte toda sua construção. Esta composição ambígua não só assinala uma apreensão formal madura do objeto, como acusa sua inoperância na medida em que o apresenta como um furo: um tecido com figuração reconhecível e relativamente familiar, mas que ao 
final aponta para um objeto informe e estrangeiro, que é o sentido de justiça aventado pela novela. Voltando-nos ao início da discussão, este sentido de justiça, cosido do interior da malha formal da novela, passa ao largo das construções teóricas conservadoras na medida em que o corte entre coronéis e dependentes em nenhum momento é sentido como um vazio a ser preenchido. O corte é, como vimos, lugar de continuidade e articulação do sistema, e é ele mesmo o local em que a narrativa rosiana habita e investe sua maior força.

Talvez o sentido de justiça acedido pela novela esteja no reconhecimento de como a alienação coronelista comunica e articula o sistema, aliado à interrupção precisamente deste conteúdo comunicado: o vazio jurídico e moral que resulta do movimento capitalista no sertão. Neste local do corte ocorre o maior empuxo formal da novela, onde a junção de perspectivas historicamente impossíveis oferece um outro tanto à civilização - pois não aponta para qualquer abstração do direito - quanto ao próprio coronelismo. $\mathrm{O}$ mesmo poderia ser dito da perspectiva do sujeito, que opera também uma negação da civilização e do corenelismo: constrói-se um outro ao sujeito total sertanejo, este capaz de tocar a lei.

Por isto o definimos apenas como um furo, que se vincula ao objeto-sertão em toda sua circunferência: porque, por um lado, apreende-o em sua totalidade funcional; e por outro o põe em relação negativa com os conteúdos ideológicos a que estava submetido, dentre eles a discussão sobre a integração do país sob um processo civilizatório. Como veremos, este furo tem a ver com os destinos da utopia do país; mais do que isto, trata-se de um próprio furo no universo do trabalho, uma vez que faz atravessar um corpo estranho nos sentidos da industrialização brasileira, seus processos integrativos etc. A apresentação do objeto-sertão como um tecido social 
furado é o grande mérito formal de Sagarana. As consequências críticas da apreensão deste furo dialético é o que vincula a obra à tradição do realismo brasileiro. 


\section{Fornação e Realismo}

O escritor britânico Louis de Bernières, em seu prefácio de 1997 à tradução inglesa das Memórias póstumas de Brás Cubas, faz um esboço rápido da vida e obra do escritor brasileiro com o intuito de apresentá-lo aos leitores estrangeiros. O prefácio deve partir do lugar-comum mercadológico - de que os consumidores conhecem pouco ou nada da tradição brasileira e menos ainda de como o autor firma nela uma posição marcante. O texto então necessita considerar a expectativa do leitor de achar num autor brasileiro uma literatura exótica, perspectiva prontamente negada pelo prefaciador, que tece uma rede de influências e comparações com autores realistas europeus e faz uso da conhecida influência inglesa sobre Machado para espantar o exotismo. $\mathrm{O}$ argumento tem no entanto estrutura curiosa, e ela é de fato o que aqui nos interessa: as relações com o cânone servem para banir a possível estranheza da literatura brasileira, afirmando Machado como um grande autor realista que passou despercebido; mas sua grandeza é extraída de sua relação incomum com o mesmo cânone. Diz o prefaciador em certo momento: 
Machado teria rido do que estou prestes a dizer (e, por favor, caro leitor, não fique desencorajado)... mas ele é de fato um escritor pósmodernista. É claro que todos sabemos que não há nada remotamente novo sobre o pós-modernismo - afinal Homero começa a Odisséia no meio do caminho e Les Liaisons Dangereuses é composta de cartas - mas há algo para além disso por aqui. Ao lado do hábito bem oitocentesco de se dirigir diretamente aos leitores, encontramos um texto que foi deliberada e jocosamente fragmentado. Encontramos passagens excêntricas e irrelevantes de seu leve filosofar, damos de encontro com capítulos compostos de apenas uma frase, capítulos que são estranhamente inconsequentes, capítulos sobre como Machado não escreveu um capítulo, capítulos que consistem de pontos e sinais de pontuação. Somos referidos a outros capítulos, como se Machado emulasse o estilo de um texto legal ou de um tratado acadêmico, e ele frequentemente reflete sobre o texto em si, de modo que ele mesmo possa afirmar: 'Eu já comparei meu estilo ao progresso de um bêbado'. (BERNIÈRES, 2008, p.ii-iii) ${ }^{65}$

Ao

leitor

brasileiro,

sobretudo ao crítico familiarizado com os avanços nem tão recentes nos estudos sobre o autor, a passagem é desconcertante. Todavia, não obstante a inconsequência do comentário a respeito de Machado, este mesmo desconcerto ilumina questões ainda candentes da crítica sobre a tradição brasileira. Atenhamo-nos sobre dois aspectos do trecho acima: o primeiro, a confusão entre o autor, Machado de Assis, e o narrador

\footnotetext{
${ }^{65}$ Tradução livre do original em inglês: "Machado would have laughed at me for what I am about to say (and please, dear reader, do not be put off)... but he is really a post-modernist writer. Of course we all know that there is nothing remotely new about post-modernism Homer begins the Odyssey half way through, after all, and Les Liaisons Dangereuses is composed of letters - but there is more of it about these days. Alongside Machado's very nineteenth century habit of confiding directly in his readers, we find a text that has been deliberately and playfully fragmented. We are offered delightfully whimsical and irrelevant passages of light philosophising, we find chapters that are only one sentence long, chapters which are quite strangely inconsequential, chapters about why Machado has not written a chapter, chapters consisting of dots and punctuation marks. We are referred to other chapters, as if Machado is spoofing a legal document or an academic tract, and he reflects often upon the text itself, so that, as he says, 'I have already compared my style to the progress of a drunk'.
} 
Brás Cubas. O segundo, a ideia de que a pós-modernidade é um conceito que somente resvala em alguma historicidade, vinculando-se mais a um estilo de escrita encontrado até em autores pré-modernos e que, deduz-se, encontrou forma plena nos escritores do século XX.

No que concerne ao primeiro aspecto, e falando especificamente de Machado, a crítica de Roberto Schwarz trabalhou de modo a esclarecer que é exatamente na disjunção entre autor e narrador que se encontra o conteúdo histórico que formaliza todos os traços ressaltados acima pelo prefaciador. O comentário ganha outro tom e faz sentido no corpo do argumento de Bernières quando posto ao lado do segundo aspecto destacado, que diz respeito às técnicas literárias da pós-modernidade. Com efeito, não há interesse por parte do comentador em separar Machado de Brás Cubas, uma vez que isto abalaria o cerne da tese do prefaciador: a saber, que de alguma forma e escritor caminham juntos, sempre, e o que define o moderno é a técnica, como espectro desta imaginada junção entre sujeito e forma. A atribuição de pósmodernidade a Machado ou Homero não pretende assim ser um comentário inteiramente extemporâneo pois carrega uma ideia estética ligada a técnicas narrativas e, em última instância, a uma ideia de sujeito por trás da narração.

Ao nos movermos do puro desconcerto diante da asserção de que Machado era um escritor pós-moderno para os fundamentos, ainda que insustentáveis, da afirmação, percebemos que há aqui um significante importante: a conjugação da ideia de sujeito à de modernidade. Deste ângulo, vê-se que o total esvaziamento da noção de história no conceito de pós-modernidade exposto acima encontra lastro numa já antiga discussão a respeito de subjetividade e modernidade, que na literatura tem em seu centro o debate sobre o romance como o gênero que sustenta essa relação. Dito de outra forma, o comentário de Bernières mostra-se como o subproduto do subproduto 
de uma longa negação do nexo acima estabelecido: de que sujeito e modernidade se combinam para a geração de um gênero específico, que é o romance. Quando se nega esta relação, todos os três elementos da equação - sujeito, modernidade e romance perdem sua especificidade histórica, como no caso acima. A negação, claro, é sintoma de algo que não cabe aqui discutir. O que nos interessa é: por que precisamente esta negação foi escolhida para a descrição e comprovação de uma não-relação entre sujeito, romance e modernidade no caso de Machado?

A negação da historicidade, como se disse, é subproduto de outra negação, que é, segundo Fredric Jameson em livro recente, a negação da própria ideia de realismo $^{66}$. Jameson coloca-se ante um dilema crítico importante: se o recalque de qualquer função de veracidade ligada à estética do romance resulta numa periodização infértil de gêneros literários (ou, no pior dos cenários, na catalogação de estilos, como o estilo pós-moderno atemporal), a identificação do romance ao realismo (encabeçada, de acordo com o crítico norte-americano, por três figuras-chave: Bakhtin, Auerbach e Lukács) leva a outro problema: a necessidade de colocar o capitalismo no centro da história humana e lidar com as ideologias secretadas pela centralidade do romance enquanto gênero realista. Isto é, se a função de veracidade do romance, sua capacidade de descobrir dinâmicas sociais e abrir-se a outras perspectivas, ligam-se incondicionalmente à forma do romance, dá-se lugar a outro tipo de desinflação da história, que é, por exemplo, a assunção de Bakhtin da “'romancidade' como um signo em si, talvez o signo e sintoma fundamental de uma

\footnotetext{
${ }^{66}$ Ver The Antinomies of Realism, 2013.
} 
'modernidade' que pode ser encontrada plenamente no mundo alexandrino tanto quanto na dinastia Ming” (JAMESON, 2013, p.3) ${ }^{67}$.

Há, portanto, nesta hesitação do conceito de realismo, mesmo perante seus defensores, uma oscilação entre uma noção de forma que simplesmente registra um dado estado de uma sociedade - suas estruturas íntimas de funcionamento - e as potencialidades políticas desta mesma sociedade. Em poucas palavras, o conceito de realismo vibraria entre o conhecimento e a utopia, e nesta vibração mesma estaria sua relação com a história e, mais especificamente, com a história do capitalismo. Seguindo o argumento de Jameson, a complicada relação entre história e realismo plasmada na forma e postada entre estes dois termos, conhecimento e utopia - deve sua conformação geral ao desenvolvimento do romance como gênero 'desmitificante'. Diz o crítico:

O realismo como uma forma (ou modo) é historicamente associado [...] com a função de desmistificação. É uma função que pode tomar muitas formas, e nesta instância fundacional o minar da fábula romanesca [romance] enquanto gênero, ao lado do uso de seus valores idealizantes que trazem a proscênio aspectos da sociedade que a idealização não pode acomodar. Eu mencionei um primeiro período da modernidade no qual as tarefas do Esclarecimento e em particular a secularização foram fundamentais (numa espécie de revolução cultural burguesa): estas são para o realismo tarefas essencialmente negativas, críticas ou destrutivas que mais tarde abrirão caminho para a construção da subjetividade burguesa (Idem, p. 4$)^{68}$.

\footnotetext{
${ }^{67}$ Tradução livre do original em inglês: "'novel-ness' is itself a sign, perhaps the fundamental sign and symptom, of a 'modernity' that can be found in the Alexandrian world fully as much as in the Ming dynasty".

${ }^{68}$ Traduzido do original em inglês: "Realism as a form (or mode) is historically associated [...] with the function of demystification. It is a function which can take many forms, in this foundational instance of the undermining of romance as a genre, along with the use of its idealizing values to foreground features of the social reality they cannot accommodate. I have mentioned a first period of modernity in which the tasks of enlightenment and in particular secularization were fundamental (in a kind of bourgeois cultural revolution): these are for realism essentially negative, critical or destructive tasks which will later on give way to the construction of bourgeois subjectivity".
} 
Torna-se claro que, para o crítico, as funções críticas e negativas deste primeiro impulso do romance realista foram os atributos decantados por Lukács, Auerbach e Bakthin para a formação de suas respectivas teorias do romance, em que estes atributos figuram em primeiro plano como marcadores estéticos que, em si, garantem uma relação com o mundo social. Em outras palavras, o que era um resíduo histórico das lutas burguesas, plasmadas no Esclarecimento e em seu entrelaçamento com o romance, é alçado à categoria de conceito estético perene: a saber, a 'romancidade'.

A ideia de que este conceito diz respeito à desmistificação de 'ilusões' sobrevive portanto à própria história e luta de classes da burguesia europeia e abre espaço para que o realismo acomode sua própria produção ideológica: "Mas a ideologia mesma do realismo também tende a ser encenada em termos de conteúdo, e aqui claramente o modo realista é intimamente associado à burguesia e ao vir a ser do cotidiano burguês: isto, gostaria de insistir, é também em grande medida uma construção, e é uma construção da qual participam o realismo e a narrativa" (Idem, p.5 $)^{69}$. Esta construção, importante dizer, é exatamente o nexo a que nos referimos acima: a necessária relação entre sujeito, modernidade e romance, com a expectativa crítica do desfazimento de ilusões.

Por este motivo pode-se dizer que o juízo de Bernières sobre Machado encontra lastro na discussão realista: mais especificamente, na assunção de que sujeito e romance geram uma forma que reproduz as potencialidades da vida burguesa 'desmitificada'. Isto se dá, importante repetir, sob a forma de recalque, pois, não

\footnotetext{
${ }^{69}$ Tradução livre do original em inglês: "But the very ideology of realism also tends to stage it in terms of content, and here clearly the realist mode is closely associated with the bourgeoisie and the coming into being of bourgeois life: this, I would like to insist, is also very much a construction, and is a construction in which realism and narrative participate".
} 
achando nada desta construção da vida burguesa (e, mais especificamente, a noção de processo narrativo que acompanha a função romanesca que conjuga construção da subjetividade e descrição da vida burguesa), julga-se que o lastro com a modernidade está perdido. Logo, a única maneira de explicar um escritor realista fora da modernidade é taxá-lo de pós-moderno avant la lettre e presumir que a potência de seu texto é técnica, e não advém de um arranjo realista, pois este falta.

Como já foi dito, os trabalhos de Schwarz trataram de mostrar a inverdade desta assunção, em larga medida mostrando como dinâmicas sociais podem figurar, na forma, de modo a mostrar a desconstrução do sujeito como um dado apreendido da matéria histórica. As consequências da descoberta são importantes não só porque mostram o desconcerto da crítica a-histórica; mas sobretudo porque levantam suspeita sobre as relações que verdadeiramente constituem o realismo. Isto é: trata-se de perguntar, com Schwarz e Machado, o que de fato a forma pode apreender das dinâmicas capitalistas.

Ao colocarmo-nos este questionamento, percebemos que há ainda um vasto campo inexplorado pela crítica em geral: isto se dá em parte porque o conceito de realismo em si sofreu com um contínuo processo de recalque, sobretudo pela crítica norte-americana. Este recalque, no entanto, é ineficaz no desmanche das relações subterrâneas que o próprio realismo teceu entre sujeito e romance, como fica claro no comentário de Bernières. Em se tratando da discussão brasileira, no entanto, a questão torna-se ainda mais grave, pois a descaracterização do conceito não diz respeito apenas a vogas acadêmicas - a uma possível saturação da discussão. Se nos permitirmos a paródia da conhecida frase schwarziana, trata-se de um recalque de segundo grau, uma vez que a aposta na relação entre sujeito, história e forma reclama a interpretação de um grande desconforto histórico, que é a história de nossa não- 
formação burguesa. Talvez não seja fortuito, portanto, que a crítica de um autor do porte de Guimarães Rosa abrigue um conluio tão profundo com este recalque. Nestas páginas finais, gostaria então de ensaiar uma descida a este inconsciente político que rege parte importante da crítica de Rosa.

Antonio Pasta Júnior, na coleção de ensaios que forma sua tese de livredocência, a Formação supressiva - constantes estruturais do romance brasileiro, oferece um dos melhores exemplos do estado de discussões teóricas acerca do problema do realismo e romance no Brasil. O crítico constrói sua argumentação face ao incômodo teórico gerado pelo enfrentamento de alguns dos principais romances brasileiros. Sobre O Ateneu, de Raul Pompéia, ele afirma: “o livro cada vez mais se revelava como narrado desde um ponto de vista que não se constituíra" (PASTA JÚNIOR, 2011, p.7). O problema, apresentando-se em forma de paradoxo, se desenrola na formação de uma perspectiva narrativa impossível, em que "o passado, objeto da narração, era passado, mas, ao mesmo tempo, não passara, ocupava o presente, fazia deste seu duplo e prometia replicar-se no futuro" (Idem, Ibidem). Desta instabilidade na relação entre sujeito, narrativa e tempo, chega-se à raiz do paradoxo, que é: um ponto de vista se formou, caso contrário o romance no Brasil seria impossível; mas se formou atravessando esta não-formação, e isto é o que lhe empresta suas características fundamentais.

Pasta Júnior assim chega a uma fórmula estrutural do romance brasileiro, que é a de que este se forma num regime paradoxal, "que sustenta a expressão de que $o$ mesmo é o outro, ou seja, reiterando, que a diferença existe e não existe" (Idem, p.9, 
grifo no original). A fórmula é bastante precisa e, sabe-se, deve muito a dois textos de Antonio Candido: A Formação da Literatura Brasileira e "O homem dos avessos", como se o paradoxo oscilasse entre os dois termos dos achados teóricos de Candido: a saber, de que a literatura se formou e de que esta encontra, em Grande sertão: veredas, um exemplo de romance paradoxal que não obstante reclama incessantemente atenção crítica - algo de uma revisão constante da tradição que o mesmo crítico afirmou formar-se com Machado.

Há também, na tese de Pasta Júnior, uma interessante proposição sobre a mimese no romance brasileiro, que a coloca em direto contato com a tradição de teóricos do realismo. Ao afirmar a formação supressiva dos textos brasileiros, Pasta Júnior encontra certa estabilização do paradoxo na premissa de que o que sustenta a ‘impossibilidade possível' do nosso romance é precisamente a mimese de nossa nãoformação. Haveria, em verdade, a mimese de uma formação moderna autoritária, expressa nos termos expostos pelo crítico em seu regime da diferença na tradição brasileira: a diferença, tal como a modernidade brasileira, existe e não existe, o outro é reconhecido e atravessado pelo sujeito, e deste atravessamento nasce o estatuto do romance.

Uma clara identificação deste outro e o respeito à sua diferença parecem dizer respeito a essa mimese autoritária em um sentido mais profundo do que apenas o barramento de uma ordem democrática, tanto no romance quanto em matéria social. Eles versam sobre o próprio regime da negação que identificamos acima, que no romance em formação concernia à própria constituição do sujeito burguês contra as ilusões da aristocracia, da religião, do mito em suma. Na tradição brasileira, e em Guimarães Rosa sobretudo, a dinamicidade das narrativas parece alocar seu caráter negativo em outro lugar que não no ataque àquilo que caracterizaria a modernidade da 
narração: a saber, a negatividade como compromisso com a escansão dos processos sociais como tais, de modo que um tipo específico de subjetividade se forme a despeito ou mesmo contra políticas de privilégio. Aqui se encontra uma das chaves para o entendimento da ideia de impossibilidade em Pasta Júnior, dado que para o crítico há aspectos modernos em nossas narrativas, muito embora estes 'errem de alvo' ao dirigirem suas potencialidades críticas à própria matéria da modernidade, isto é, à relação estável entre sujeito e objeto. Ou seja, o romance se forma, muito obstante nutrindo-se do mito como barramento da forma nos momentos em que esta não pode avançar sobre a constituição anti-burguesa da sociedade. Daí seu aspecto paradoxal.

Como sugerimos, esta visão sobre o romance brasileiro vincula-se a duas chaves de pensamento, que em muitos momentos se fusionaram em nossa história intelectual: o pensamento formativo e a teoria do realismo. $\mathrm{O}$ argumento habita a formação, porque carrega, na própria veia do impossível, um desejo de reconciliar o foco local a uma atribuição de valor ao possivel: isto é, à formação da sociedade e do sujeito. O caso de Pasta Júnior, é muito diverso, é claro, daqueles dos primeiros autores formativos: Gilberto Freyre, Caio Prado Jr., Celso Furtado e mesmo Antonio Candido. Trata-se de uma perspectiva que trata da perda da utopia já como um fato, ou do barramento à vida burguesa plena como dado a ser perscrutado. Mas este luto, se assim pudermos dizer, é exatamente o elemento que impulsiona a teoria do realismo do crítico a levar a sério a afirmação de Roberto Schwarz, tratando dos autores da formação: "não há como saltar por sobre sua própria sombra" (SCHWARZ, 1999, p.11).

A impossibilidade gera assim uma necessidade de ajuste na teoria realista, em que a formação supressiva se transforma no dado recolhido da vida social. O luto, transformado em motor da forma, guarda a utopia de emancipação em camadas mais 
profundas dos textos literários. É a maneira como podemos compreender a tese de Pasta Júnior sobre o romance rosiano: em Grande sertão: veredas haveria "a vigência simultânea de dois regimes da relação sujeito-objeto - um que supõe a distinção entre sujeito e objeto ou, se se quiser, o mesmo e o outro, e um segundo que supõe a indistinção de ambos". O crítico continua: "não se trata aí de uma mistura entre outras, a acrescentar à extensa lista de hibridismos, mas do princípio mesmo de hibridização que, dando-se no nível fundamental da própria relação sujeito-objeto, determina a lógica de base do livro e responde pelo conjunto de sua estruturação formal" (PASTA JÚNIOR, 2011, p.150, grifo meu). Ou seja, o crítico reconhece alguma 'romancidade' em Rosa, para falar com Jameson, mas presume que a coabitação da relação de distinção entre sujeito e objeto com a da indistinção é o próprio fator estruturante da forma. Ou seja, à expectativa de emancipação alocada na romancidade conjuga-se seu barramento necessário: como que se a individuação romanesca vivesse enlaçada a um princípio formal que mimetiza uma falta, agindo assim como função formal que barra a potencialidade burguesa: "esse motor paradoxal é, no entanto, incapaz de produzir a diferença ou de encaminhar a transformação" (Idem, p.151).

A crítica de Pasta Júnior atravessa sendas estreitas e propõe avanços à crítica do romance brasileiro que talvez não tivessem sido atingido desde o trabalho de Schwarz sobre Machado. O vínculo negativo com o espírito formativo e a manutenção do luto como significante de uma formação interrompida parecem impedi-lo, todavia, de dar o salto necessário a uma teoria realista que desvincule o realismo aos processos de formação clássica da burguesia europeia. Atravessando caminhos muito diversos, os resultados deste impasse parecem dar de frente com as dificuldades de se estabelecer qual o vínculo entre forma e capitalismo. Quando este 
não nega o mito, o que de fato ele nega para constituir-se? O desafio torna-se então o de encontrar o lastro para outros tipos de negação dentro de processos capitalistas. Este desafio reflete no próprio uso do significante moderno nos escritos brasileiros: o romance nacional é moderno, apesar de não sê-lo, ou sê-lo via falta.

A identificação de dois núcleos formais na crítica de Pasta Júnior a Rosa - um moderno e outro que atravessa este moderno - é um grande passo na crítica rosiana pelo fato de presumir que todas as instâncias do texto de Rosa respondem a uma dinâmica histórica. Esta presunção leva à dialetização dos dois termos acima de modo a gerar um comentário vivo sobre o romance brasileiro e, mais especificamente, sobre Guimarães Rosa. Esta dialética, no entanto, gira em falso ao tocar no seu elemento mimético, que é o ponto em que forma literária e forma social interagem. No momento em que esta interação deve ter lugar, ela é substituída por um vínculo negativo, que lhe é legado pelo luto sobre a não-formação. A mimese do polo nãomoderno da forma, neste caso, se dá sobre os quistos sociais que a negatividade de nosso capitalismo não conseguiu dissolver, e este é o momento em que moderno e não-moderno interrompem sua dialeticidade e sustentam-se novamente como dois termos opostos, abstratos e sem contradição real. De um lado, resta o romance com uma dinâmica própria; de outro, a sociedade, com sua falta de dinâmicas. Este é o quadro que leva Pasta Júnior a propor dois regimes formais atuando em Grande sertão: veredas ao mesmo tempo: dois princípios que respeitam as dinâmicas processuais e não-processuais que em sua atuação paradoxal geram a forma rosiana.

O modo como se dá esta interação - numa espécie de ponto cego da forma, em que os dois regimes atuam ao mesmo tempo sem necessariamente se informarem mutuamente - é um achado importante sobre a pesquisa sobre o autor. O passo fundamental a ser dado, no entanto, diz respeito a esta interação obscura entre 
processos narrativos e seu estancamento, e a mimese que ocorre neste ponto. É neste local da forma que se advoca a atuação de um objeto - o sertão - que atua numa mimese positiva - não sobre a via da falta - cujos resultados lançam uma nota de suspeita diretamente ao coração da teoria realista e a presunção de romancidade em sua relação com formas sociais burguesas. A pergunta que guia este capítulo final, em face das análises dos funcionamentos básicos da forma rosiana que expusemos até aqui, seria portanto: o que aconteceria com a crítica de Rosa se propuséssemos uma mimese independente da própria ideologia do realismo: a saber, a despeito da ideia de que os processos de negação, desconstrução e crítica do realismo necessariamente levam a um regime estável da diferença, no qual a relação entre sujeito e objeto é respeitada? A estabilidade, neste caso, passaria a ser menos um atributo do romance enquanto gênero, e mais uma consequência de uma mimese específica: o caso europeu do século XIX.

A hipótese deixa a questão pendendo sobre a questão mimética, que no fundo não é muito diferente da investigação de Candido em 1959 a respeito do romance enquanto forma e a matéria brasileira. $\mathrm{O}$ estado das pesquisas atuais, em muito informado pelo próprio desenrolar histórico brasileiro das últimas cinco décadas, impede que apenas aceitemos a hipótese da formação como um todo. Mas a projeção utópica lançada por estes autores - a de que haveria um momento em que pensamento e processos sociais andariam juntos - e sua capitulação histórica criam um cenário favorável à crítica. Por um lado, dão acesso ao tipo de utopia que circulava na época em torno da industrialização do país; por outro, fornecem precisamente o elemento a ser criticado: a expectativa quanto às potencialidades e conteúdos da vida burguesa; não porque estes foram barrados, mas porque o próprio barramento aponta para uma 
arena de luta de classes. Esta arena e sua dramaticidade podem nos parecer distantes, mas informaram a literatura de outra perspectiva que não a da falta.

Noutras palavras, o pensamento formativo fornece a arena ideológica que ajuda a perceber o barramento da mesma utopia, esta falta, menos como substância histórica - um ente que pode ser mimetizado nos romances - e mais como um limite às contradições da época: isto é, um sujeito que se esconde precisamente na quina deste pensamento e que age, processualmente, na capitulação dos processos burgueses clássicos. A questão é nuançada e, do ponto de vista histórico, não chega a oferecer uma reviravolta em nossa história de industrialização. Mas a mudança de perspectiva - do luto à luta de classes - gera consequências importantes se se quiser estender a teoria do realismo ao caso brasileiro. É neste ponto que se chega a um questionamento sobre a função de veracidade do realismo: se, com Jameson, dissermos que "se é verdade social ou conhecimento que queremos do realismo, logo descobrimos que o recebemos é ideologia" (JAMESON, 2013, p.6) ${ }^{70}$, percebemos o valor do estudo de peças literárias versam sobre a instabilidade de uma ideologia, como o caso da ideologia formativa e sua expectativa de que sujeito e processos sociais se unissem contra o atraso de nossa matéria social.

Isto é particularmente importante para o caso brasileiro e Guimarães Rosa. Como buscamos mostrar nas análises precedentes, as narrativas apresentam muitas portas de entrada que poderíamos chamar ideológicas: seja a ideologia coronelista de “A volta do marido pródigo" ou "A hora e a vez de Augusto Matraga"; seja ideologia de classe média urbana, positivista, interessada nos males da nação em "Sarapalha"; seja por fim a própria ideologia do intelectual culto ante a matéria tosca, em busca da ficção, em "Conversa de bois". Todas as portas de entrada ideológicas são

\footnotetext{
${ }^{70}$ Tradução livre do original em inglês: "If it is social truth or knowledge we want from realism, we will soon find that what we get is ideology".
} 
apresentadas e, por que não dizer, recebem investimento narrativo. Este investimento narrativo abre espaço para a problemática do mito, já citada, quando a novela flerta com perspectivas sociais restritas em detrimento de outras e, mais importante, gera pontos de ofuscamento em lugares em que processos sociais importantes poderiam ser iluminados.

Os investimentos, como procuramos mostrar, são não obstante instáveis o suficiente para abrir espaço a algo que é estranho a estas ideologias. Em todos os casos apresentados nesta tese, a figura do narrador, ou simplesmente a voz narrativa, sofre com as distorções de perspectiva geradas por seu próprio conteúdo, que as obriga a desarvorar-se das posições ideológicas iniciais e dar espaço a outros processos semânticos que, se não são contraditórios a estas posições iniciais, no mínimo lhes causam problemas. Em casos como "Conversa de bois", a estruturação da narrativa em camadas sobre camadas de instâncias narrativas subverte a intenção inicial da novela - uma inconsequente conversa entre um bacharel e um capiau sobre um tópico fantástico - para revelar conteúdos dramáticos que lhes escapam totalmente. Para onde escapam, no entanto? Este é a tese que procuramos demonstrar: escapam precisam para esta fresta ideológica do pensamento formativo, que se irmana à ideia de romancidade: a saber, que modernidade deve significar a estabilização de processos narrativos. Mais importante ainda é o reconhecimento de que o ponto de fuga aponta para um processo real, que é o de afirmação de um espaço mínimo de abstração do trabalho e as consequências da figuração deste espaço à perspectiva sertaneja.

$\mathrm{Na}$ expectativa de equilíbrio da forma sob os processos industriais se esconde precisamente o sertão como objeto que não é alheio a estas dinâmicas, mas lhes é o ponto de cesura. Noutras palavras, o ponto de fuga se dá na conformação do próprio 
universo da luta de classes às demandas capitalistas de abstração do trabalho, circulação do valor e exploração. Neste ponto de escape se forma o sertão como objeto em direta relação com a matéria histórica brasileira da primeira metade do século passado. A compreensão da formação do sertão como objeto é o que evidencia o drama da formação menos como uma expectativa utópica e mais como um limite às tensões sociais do período.

O caso de "A hora e a vez de Augusto Matraga" talvez seja mais emblemático na demonstração de como a narrativa rosiana escorrega pelas fendas da ideologia formativa. O conteúdo da saga obriga o narrador a acompanhar sua personagem no vagar pelas muitas camadas do universo sertanejo, obrigando-o aos ajustes de perspectiva que, a cada momento, liberam um conteúdo novo daquela matéria social e, pode-se dizer, apresentam as infiltrações da ideologia coronelista. Mais do que isto, no entanto, importa notar o momento esperado pelo narrador: aquele em que, num salto final, a narrativa de uma estória ordinária se transforma em extraordinária. Neste momento, não há endosso a qualquer visão ideológica: Matraga é, com efeito, o ponto em que toda a narrativa dobra-se sobre si como dupla negação da ordem coronelista e da civilização, representada pela abstração do direito. A novela aponta a todo momento para o ponto que define o sertão em toda sua ambiguidade: um topos socialhistórico que demonstra todas suas ligações com as dinâmicas sociais do período, mas que guarda em si o ponto em que estas dinâmicas comunica um vazio. Como vimos, a novela incansavelmente aponta para este vazio, que existe, para apreender-se dele para gestar uma noção de justiça que supera todos os vetores apresentados na malha narrativa.

Nesta noção de justiça, poder-se-ia dizer, tem-se o retorno do mito, já que da justiça nada se pode dizer da matéria social. Isto é, foge-lhe a função de veracidade 
esperada da narrativa realista e o ponto de mimese é aparentemente rompido. Este é o ponto que, não obstante, interessa à crítica, pois revela o duplo vínculo da prosa rosiana com a utopia formativa - um positivo e outro negativo: por um lado, junto aos autores da formação, atesta simultaneamente o vigor e a capitulação da ordem oligárquica; por outro, contra a formação, nega-se o vínculo do sentido de justiça, advindo da destruição da ordem coronelista, a qualquer síntese histórica: sobretudo o nexo advindo da harmonização das dinâmicas burguês com um sujeito burguês. Noutras palavras, o fato de a justiça e a redenção de Matraga não terem qualquer direção oferece um trunfo a sua narrativa: ela ataca precisamente um dos pontos mais resilientes da própria ideologia da romancidade.

Nesta desconexão poderia residir o segundo registro sob o qual opera a obra rosiana, de acordo com Pasta Júnior, aquele em que sujeito e objeto se confundem: neste caso, o exemplo é bem vindo, pois Matraga é redenção para Nhô Augusto, sujeito e objeto de si mesmo, mas estranhamente exerce a mesma confusão sobre o sistema jagunço/coronelista, de onde a narrativa extraiu todas suas forças, já que o suspende e em certa medida impede sua operação. Desta desconexão poder-se-ia dizer, portanto, que dela nasce a mimese da falta, como em Pasta Júnior: a saber, um raciocínio que junge a recusa da forma de Rosa de se ligar permanentemente a qualquer síntese dos processos históricos do sertão à apreensão de um dado: a destruição da ordem coronelista não levou os sertanejos à cidadania. Daí, talvez, a suspensão do sentido de justiça na novela.

Como sugerimos, existe no duplo registro sugerido por Pasta Júnior uma ligação estreita com a teoria do romance que propõe que há, na forma do gênero em si, um lastro de processualidade que tem a ver com o moderno. Tratar-se-ia de processos narrativos que, assim como a subjetividade moderna, se utilizaria da 
negatividade da crítica para o estabelecimento da relação sujeito-objeto de modo a atacar o pensamento mítico. O espanto quanto a Rosa, no entanto, adviria de um escorregamento desta negatividade do moderno, ou da romancidade, para o próprio registro mítico, servindo de combustível para o último em um processo de crítica que atinge a própria racionalidade (daí, segundo o crítico, a tendência do texto rosiano de recepcionar leituras místicas). "Augusto Matraga", antecipando Grande sertão: veredas, seria um grande exemplo desse uso do moderno contra si, já que no momento da crítica, a novela a nega, e utiliza esta negatividade para elevar à hagiografia o sentido de justiça.

O que procuramos demonstrar neste texto, atentando aos processos fundamentais de formação na obra de Rosa, foi entretanto que esta negatividade não pertence ao gênero literário moderno como atributo estanque - ou, mais radicalmente, que romance e realismo devem ser ter seu nexo obrigatório desfeito ${ }^{71}$. $\mathrm{O}$ uso surpreendente da matéria histórica da primeira república brasileira sugere um realismo não atrelado a processos de totalização habitualmente vinculados ao romance. Com efeito, poder-se-ia argumentar precisamente o contrário: o estancamento das novelas, o momento em que estas são finalizadas, revela um atributo essencial desta negatividade, ligada ao realismo mas não necessariamente atrelada ao romance, que desejamos discutir.

Veja-se o caso de "A volta do marido pródigo": a narrativa adquire alta processualidade quando Lalino imerge na roda da política coronelista; mas a mesma processualidade é suspensa ao final quando o narrador dá de ombros e considera a história finalizada. O corte feito pelo narrador é fundamental pois exerce um efeito de

\footnotetext{
${ }^{71}$ Não se ignora todavia uma tendência estruturante do realismo que muito provavelmente contribuiu à identificação do conceito ao gênero-romance: a saber, o realismo deve ainda dizer respeito a processos de totalização na narrativa. Este ponto, longe de ser simples, receberá tratamento à frente com direcionamentos que julgamos necessários à discussão.
} 
contraste com o processo narrativo anterior, deixando claro que este não lhe pertence; ou, em outras palavras, que o processo é mimese, e ele mesmo - o narrador - está submetido a ela, e para dar fecho à estória precisa dela retirar-se.

Aqui encontramos novamente uma desconexão e o efeito de uma negação, mais claramente destacados como a cesura entre mimese histórica e os esforços do narrador. Da desconexão, seria possível afirmar que testemunha em favor da falta de romancidade, pois o narrador não consegue dar conta dos processos de totalização necessários para a sustentação do processo na narrativa. Mas o que fica claro com a análise da novela é que a totalização já está lá, desconcertantemente apresentada como um processo circular que envolve todos os níveis da vida sertaneja. Como o narrador se subtrai do processo é portanto menos uma 'falha' - ou um atestado da falta brasileira - e mais um dado da formalização da matéria social em questão: a saber, o narrador precisa, atabalhoadamente se se quiser, sacrificar-se em favor do efeito de uma ciranda sem rumo. Como se, escusada a perda da voz narrativa, ganhasse o leitor com a noção de que, não fosse o fim abrupto, a estória continuaria girando e girando em torno dos processos de perda e reconquista do poder coronelista.

A questão sobre os dois registros na obra rosiana retorna assim por outro lado: percebe-se que o processo de totalização em Rosa carrega esta questão: como manter a mimese e finalizar uma obra? As duas alternativas que encontramos estão presentes em Sagarana e Grande sertão: ou sacrifica-se o narrador, ou armam-se dispositivos narrativos que possibilitem que a narrativa flerte com o infinito retorno ao mesmo ponto. Em ambos os casos, no entanto, encontra-se o efeito realista, que se mostra simplesmente como a formalização dos processos de acumulação. Pasta Júnior parte da mesma premissa, mas presume que acumulação equivalha à romancidade, à construção subjetiva e, por fim, à sustentação de uma síntese crítica pela instância 
narrativa. Como estes aspectos faltam em Rosa, a adequação teórica se dá via exclusão do narrador da mimese acumulativa: em outras palavras, quando o narrador se subtrai, aí está a prova de que a própria acumulação brasileira esbarra em algo.

A ideia da 'construção interrompida', novamente, remete à tradição formativa e seus espólios, e em suas versões mais sofisticadas, apontam a inépcia ou acomodação da burguesia diante das potencialidades da economia brasileira em meados do século passado. Análises como a de Florestan Fernandes em A revolução burguesa no Brasil são agudas na identificação das causas deste barramento que, inegavelmente, fazem divergir os processos de modernização brasileira daqueles das sociedades capitalistas centrais. O que a noção de 'construção interrompida' esconde no entanto é seu vínculo com uma idealização destes mesmos processos burgueses, que não raro joga uma sombra sobre a própria ideia de acumulação. $\mathrm{O}$ pressuposto, parecido com o da romancidade, é de que os esforços acumulativos da classe burguesa, ao encontrarem condições ideais, podem liberar uma potência de secularização e modernização que garante efeitos na 'superestrutura', como uma cidadania efetiva e estruturas políticas mais democráticas.

O fato de que este foi o caso em muitas sociedades sugere um caminho utópico-formativo, que mascara aspectos essenciais da acumulação capitalista e mesmo como o capital opera processos de negação e totalização. A ilusão de que a subjetividade burguesa, sob o capitalismo, encontra um nexo construtivo sobre o esteio da acumulação é em grande parte gerada pela própria colocação do tema do moderno e sua capacidade de suprimir formas de produção e sociabilidade arcaicas. O tema é especialmente candente no Brasil, em larga medida pela espera que o moderno no país um dia liberasse essa potência dissolvente sobre as formas coloniais de 
arranjos políticos e econômicos. Sobre a subsunção destes 'restos' ao capital, Jorge Grespan comenta:

\begin{abstract}
A impressão de que o capital poderia realizar imediatamente sua disposição a 'subordinar a si todos os elementos da sociedade' vem do aspecto contínuo apresentado à primeira vista pela acumulação, que parece prosseguir indefinidamente sem se fixar em ponto algum. Esta ausência aparente de balizas na continuidade do decorrer da acumulação faz com que se obscureçam as demarcações de tempo deste processo, e, assim, também a própria percepção do processo e do tempo que ele requer para se realizar. Donde a ilusão de imeditiacidade. (GRESPAN, 2012, p.227-228, grifo meu).
\end{abstract}

A determinação dos tempos deste processo, segundo Grespan, depende da maneira como capital e trabalho se entrelaçam, e nesta mediação se dá a forma como a acumulação lida com seus 'restos'. Mas mesmo da perspectiva da burguesia, a ilusão de continuidade indistinta na acumulação do valor é insustentável. Isto porque, mesmo no processo burguês mais fundamental, a "soma limitada de dinheiro é sempre o fim de uma etapa da acumulação e o início de outra, diferenciando-as e demarcando pontos de partida e de chegada como patamares no processo ao infinito". A infinitude linear seria como que uma ilusão de ótica - ou de perspectiva - gerada "através da sucessão de pontos determinados, constantemente superados uns pelos outros em seu caráter finito" (Idem, p.228).

O desfazimento desta ilusão é tarefa primordial à análise dos processos capitalistas brasileiros, especialmente porque na primeira metade do século XX os caminhos para a acumulação, após a libertação dos escravos, assumem formas que pouco lembram uma linearidade. Com efeito, se utilizarmos a imagem de Grespan, o pontilhismo que caracteriza a 'tarefa de Sísifo' da acumulação brasileira tem que se haver com um desafio básico, que é o de fazer o capital pôr-se em contato com o 
trabalho. A saber, uma consequência aparentemente natural do fim da escravidão - a mão-de-obra dependente e cativa se tornar disponível à valorização do valor - é em si um obstáculo para que a burguesia exerça sua 'potência'. A enorme discrepância entre regiões produtoras no país, somada à essa difícil relação entre trabalho e capital, faz com que o pontilhismo dê voltas sobre si, desenhando a face de um processo em que a acumulação brasileira muitas vezes rodopiou em falso - como na primeira república formando a imagem de um moderno sempre tendo de se haver com avanços, retrocessos, solavancos etc.

Ou seja, o regime do sujeito-objeto idealizado e projetado pela noção de uma construção linear do capital é sempre atravessado por seu outro: a crise como um limite e ao mesmo tempo medida da valorização; como "barreira a ser continuamente ultrapassada por esse impulso infinito de autovalorização" (Idem, p.14), na qual construção e desconstrução, superação e mergulho na crise, são lados da mesma moeda. O problema colocado pelo cenário brasileiro da primeira metade do século XX encontra assim ângulo e perspectiva formal em Rosa próximos a este limite e abaixo das correntes utópicas formativas, que viam no processo de industrialização uma possibilidade de coerência e construção. A escolha do sertão como objeto impõe à forma uma relação próxima às convulsões do mundo do trabalho nestas décadas que definiram os contornos da industrialização brasileira: daí nossa atenção à destruição de antigos laços de dependência, à política coronelista. Mas, sobretudo, o foco no árduo processo de abstração do trabalho, esta sim condição sine qua non para os processos industriais, mostrou-se o ponto nodal da problemática sertaneja.

O dilema brasileiro, a ultrapassagem industrial de seus restos coloniais, traduzia-se nos esforços de totalização do capital no país via abstração do trabalho: a saber, um esforço pela quebra da pessoalidade das relações de trabalho e pela 
mediação abstrata do valor. Como se viu, também este processo não foi simples e encontrou suporte, durante algumas décadas, nos ciclos da política coronelista. Ao forjar séries de expansão horizontal da produção interiorana, o coronelismo sustentou um complexo círculo de circulação de poder que se ligava direta e indiretamente com a produção de mercadorias. Neste círculo viu-se a importância do que chamamos de acumulação primitiva: o ponto que agora podemos chamar de ponto limite dos processos de acumulação nas décadas estudadas. Isto porque dava-se como movimento que liberava terras e mão-de-obra para futuras expansões - incluindo-as no processo de totalização do capital - ao mesmo tempo em que mantinha o controle pessoal sobre a terra e negava aos dependentes pobres a possibilidade efetiva de venda de força de trabalho. Este nó - pontos tecidos nessa costura dentro e fora do capital - constituiu o limite de totalização do capitalismo brasileiro, e foi também através desta saturação do ciclo coronelista que nasceram as principais 'soluções' getulistas para o problema do trabalho nas décadas subsequentes ${ }^{72}$.

A proximidade deste limite, e sobretudo sua formalização por Rosa, reveste de novo sentido a ideia de tradição cunhada por Candido na Formação da literatura brasileira. Se levarmos a sério as movimentações críticas do argumento, da inadequação de uma romancidade à realidade brasileira, e se aceitarmos, com Candido, que Machado de Assis encontra uma estabilização relativa ao problema, forjando o primeiro passo desta tradição, encontramos mais questões do que respostas. Primeiro, de que modo se dá esta estabilização? Se olharmos para Machado, é certo que a solução não passa por qualquer apaziguamento da forma através de um ajuste da romancidade à 'modernidade' brasileira. Pelo contrário: o que Candido percebeu e Schwarz tratou de expor em minúcia é a formalização de uma

\footnotetext{
${ }^{72}$ Ver o já comentado livro de Francisco de Oliveira, Crítica à razão dualista - o ornitorrinco.
} 
modernidade às avessas, convulsionada em cada uma das débeis tentativas de legitimação.

Outra questão que emerge é: o que é, enfim, a realidade brasileira de que a literatura deve falar? A resposta a que somos conduzidos por Candido é esta do limite mesmo do moderno, do ponto em que a modernidade mostra sua face negativa como pura luta de classes nas franjas da superação acumulativa. Da crise do escravismo nasce a forma de Machado não como síntese do processo, mas como a perspectiva deste abismo que enxerga do outro lado nada senão o caos produtivo e a derrocada da oligarquia escravocrata.

O mesmo pode ser dito de Guimarães Rosa: sua vista curta no que diz respeito a sínteses de processos históricos segue o pontilhismo da acumulação brasileira, dos pontos de inteligibilidade destes mesmos processos em face de seus pontos de saturação. Rosa formalizou o sertão como objeto e assim fez parte da mesma tradição aludida por Candido: uma tradição de realismos que mirava o moderno via seu dorso, ou do ponto em que o moderno se fazia através de seu negativo. Neste sentido, é impreciso dizer que Rosa previu a interrupção de nossa construção, ou mesmo capturou esta falta, pois a falta nunca esteve presente deste ângulo. Na captura destas reviravoltas, o que emergia não era o futuro que nunca chegaria, mas sim este corpo fantasmático imenso que era o sertão. A passagem do um no outro, vista daqui, era a imagem limite de um realismo.

Ou, se aproveitarmos a figura schwarziana, o salto sobre a sombra é impossível não porque nos falta um sujeito da história, mas porque este sujeito sempre preferiu estar à sombra, costurando construção nesta passagem incessante por seu outro. O romance brasileiro, talvez mais do que a crítica, percebeu esta dinâmica 
e, no caso de Guimarães Rosa, soube dar voz a este sujeito da sombra; ou, se se aceitar a hipótese deste trabalho, o sertão. 


\section{Bibliografia}

\section{Obras de Guimarães Rosa:}

ROSA, João Guimarães. Ave, palavra. $5^{\text {a }}$ ed. Rio de Janeiro: Ed. Nova Fronteira, 2001.

. Estas estórias. 5aed. Rio de Janeiro: Ed. Nova Fronteira,

2001.

. Grande sertão: veredas. $19^{\mathrm{a}}$ ed. Rio de Janeiro: Ed. Nova

Fronteira, 2001a.

. Manuelzão e Miguilim: (Corpo de Baile). $11^{\mathrm{a}}$ ed. Rio de Janeiro: Ed. Nova Fronteira, 2001.

. No Urubuquaquá, no Pinhém: (Corpo de Baile). $9^{\mathrm{a}}$ ed. Rio de

Janeiro: Ed. Nova Fronteira, 2001.

. Noites do sertão: (Corpo de Baile). $9^{\mathrm{a}}$ ed. Rio de Janeiro: Ed.

Nova Fronteira, 2001

. Primeiras Estórias. 15a ed. Rio de Janeiro: Ed. Nova Fronteira, 2001. . Sagarana. $1^{\mathrm{a}}$ ed. Rio de Janeiro: Ed. Nova Fronteira, $2001 \mathrm{~b}$. . Tutaméia (Terceiras estórias). $8^{\mathrm{a}}$ ed. Rio de Janeiro: Ed. Nova

Fronteira, 2001.

\section{Demais obras:}

ADORNO, Theodor W. Aesthetic Theory. Minneapolis: University of Minnesota Press, 1996. . Negative Dialectis. London: Routledge, 1973.

ADORNO, Theodor W.; HORKEIMER, Max. Dialética do esclarecimento: fragmentos filosóficos. Rio de Janeiro: Jorge Zahar Ed., 1985. 
. Notas de Literatura I. São Paulo: Ed. Duas Cidades; Ed. 34,

2003.

AGAMBEN, Giorgio. A comunidade que vem. Lisboa: Editorial Presença, 1993.

. Estado de exceção - Homo sacer II, 1. $2^{\mathrm{a}}$ ed. São Paulo: Ed.

Boitempo, 2007a.

. Estâncias - a palavra e o fantasma na cultura ocidental. Belo

Horizonte: Ed. UFMG, 2007 b.

- Homo Sacer: o poder soberano e a vida nua I. Belo

Horizonte: Ed. UFMG, 2002.

. Il tempo che resta - Un commento alla Lettera ai Romani.

Torino: Bollati Boringhieri editore, 2000.

. Infância e história: destruição da experiência e origem da

história. Belo Horizonte: Ed. UFMG, 2005.

. Nudez. Lisboa: Relógio D’água Editores, 2010.

. O que resta de Auschwitz: o arquivo e a testemunha (Homo

Sacer III). São Paulo: Ed. Boitempo, 2008.

- O sacramento da linguagem: Arqueologia do juramento

(Homo sacer II, 3). Belo Horizonte: Ed. UFMG, 2011.

. Profanações. São Paulo: Ed. Boitempo, 2007c.

ALENCASTRO, Luiz Felipe de. "A pré-revolução de 30" In Novos Estudos

CEBRAP, São Paulo, nº 18, p. 17-21, setembro de 1987.

ALMEIDA, Manuel Antônio de. Memórias de um sargento de milícias. $3^{\mathrm{a}}$ ed. Cotia: Ateliê Editorial, 2006.

ANDRADE, Fábio de Souza. Samuel Beckett: o silêncio possível. Cotia: Ateliê Editorial, 2001.

ANDRADE, Mário de. Aspectos da literatura brasileira. $5^{\text {a }}$ ed. São Paulo: Ed. Martins, 1974.

. O empalhador de passarinho. $3^{\mathrm{a}}$ ed. São Paulo: Ed. Martins;

Brasília: INL, 1972.

ANDRADE, Oswald de. Estética e política. São Paulo: Globo, 1992.

ARANTES, Paulo Eduardo; ARANTES, Otília Beatriz Fiori. Sentido da formação: três estudos sobre Antonio Candido, Gilda de Mello e Souza e Lúcio Costa. Rio de Janeiro: Paz e Terra, 1997. 
ARANTES, Paulo Eduardo. Sentimento da dialética na experiência intelectual brasileira: dialética e dualidade segundo Antonio Candido e Roberto Schwarz. Rio de Janeiro: Paz e Terra, 1992.

. Zero À Esquerda. São Paulo: Conrad Livros, 2004.

ARAÚJO, Heloísa Vilhena de. Guimarães Rosa: diplomata. Brasília: Ministério das Relações Exteriores, 1987.

ARENDT, Hannah. Sobre a violência. Rio de Janeiro: Relume-Dumará, 1994.

ARRIGUCCI JR., Davi. O mundo misturado - romance e experiência em Guimarães Rosa In Novos Estudos CEBRAP, São Paulo, no 40, p.7-29, Novembro 1994.

AUERBACH, Erich. Mimesis: a representação da realidade na literatura ocidental. $5^{\mathrm{a}}$ ed. São Paulo: Ed. Perspectiva, 2007. . "As flores do mal e o sublime" In Ensaios de Literatura Ocidental: filologia e crítica. São Paulo: Ed. Duas Cidades; Ed. 34, 2007.

AZEVEDO, Aluísio. O cortiço. 38 ed. São Paulo: Ática, 2011.

BADIOU, Alain. L'éloge de l'amour (avec Nicolas Truong). Paris: Flammarion, 2009a. . São Paulo: a fundação do universalismo. São Paulo: Boitempo, 2009b.

BAKHTIN, M. M., The Dialogic Imagination: Four Essays. Austin: U of Texas, 1981.

Bakhtin, M. M. Problems of Dostoevsky's Poetics. Minneapolis: U of Minnesota, 1984. Print.

BATAILLE, Georges. O erotismo. São Paulo: Ed. Arx, 2004.

Beiguelmann, Paula. A Formação Do Povo No Complexo Cafeeiro: Aspectos Políticos. São Paulo: Liv. Pioneira, 1968.

BENEDETTI, Nildo Maximo. Sagarana: o Brasil de Guimarães Rosa. São Paulo: Hedra, 2010.

BENJAMIN, Walter. Charles Baudelaire - um lírico no auge do capitalismo. São Paulo: Ed. Brasiliense, 1989. . Escritos sobre mito e linguagem (1915-1921). São Paulo: Ed.

Duas Cidades; Ed. 34, 2011. . Ensaios reunidos: escritos sobre Goethe. São Paulo: Ed. Duas

Cidades; Ed. 34, 2009. 
. Magia e técnica, arte e política. $7^{\mathrm{a}}$ ed. São Paulo: Ed. Brasiliense, 1994.

. Reflexões sobre a criança, o brinquedo e a educação. São Paulo: Ed. Duas Cidades; Ed. 34, 2002.

BERNIÈRES, Louis de. "Introduction" In ASSIS, Machado de. Epitaph of a small winner. London: Bloomsbury, 2008.

BEWES, Timothy; HALL, Timothy (orgs). Georg Lukács: the fundamental dissonance of existence - Aesthetics, Politics, Literature. New York; London: Continuum, 2011.

BOLLE, Willi. grandesertão.br: o romance de formação do Brasil. São Paulo: Ed. Duas Cidades; Ed. 34, 2004.

BOOTH, Wayne C. The rhetoric of fiction. $2^{\mathrm{a}}$ ed. Chicago \& London: The University of Chicago, 1983.

BÜRGER, Peter. Teoria da vanguarda. São Paulo: Ed. Cosac Naify, 2008.

CANDIDO, Antonio. A educação pela noite. $5^{\text {a }}$ ed. Rio de Janeiro: Ed. Ouro sobre Azul, 2006a.

. Formação da literatura brasileira: momentos decisivos, 1750-

1880. 12 $2^{\mathrm{a}}$ ed. Rio de Janeiro: Ouro sobre Azul; São Paulo: FAPESP, 2009.

. Literatura e Sociedade. $9^{\mathrm{a}}$ ed. Rio de Janeiro: Ed. Ouro sobre

Azul, 2006b.

. Os parceiros do Rio Bonito: estudo sobre o caipira paulista e a transformação dos seus meios de vida. $11^{\mathrm{a}}$ ed. Rio de Janeiro: Ouro sobre Azul, 2010. ; Outros autores. A personagem de ficção. $12^{\mathrm{a}}$ ed. São Paulo: Perspectiva, 2011.

. Tese e Antítese. $5^{\mathrm{a}}$ ed. Rio de Janeiro: Ed. Ouro sobre Azul, 2006c. . Textos de intervenção. São Paulo: Duas Cidades; Ed. 34, 2002. . Vários Escritos. 4a ed. Rio de Janeiro: Ed. Ouro sobre Azul, 2004.

CORPAS, Danielle. "Grande sertão: veredas e formação brasileira" In Revista da ANPOLL. 1908- Machado de Assis e Guimarães Rosa: aspectos lingüísticos e literários. $\mathrm{n}^{\mathrm{o}} 24$, v. 1, p. 261-288, jan./jul. 2008. 
. O jagunço somos nós: visões do Brasil na crítica de Grande sertão: veredas. 2006. 270 f. Tese (Doutorado em Teoria Literária) - Faculdade de Letras, Universidade Federal do Rio de Janeiro, Rio de Janeiro, 2006.

LORENZ, Günter; COUTINHO, Eduardo F. (org.). "Diálogo com Guimarães Rosa" In Guimarães Rosa. Rio de Janeiro: Ed. Civilização Brasileira, 1991.

FAUSTO, Boris. A revolução de 1930: historiografia e história. São Paulo: Companhia das Letras, 1997.

FAUSTO, Boris (org). História Geral Da Civilização Brasileira, Tomo III: O Brasil Republicano. $8^{\mathrm{a}}$ ed. Vol. 8. Rio De Janeiro: Bertrand Brasil, 2006.

. História Geral Da Civilização Brasileira, Tomo III: O Brasil

Republicano. Vol. 2. São Paulo: Difel, 1977.

.. História Geral Da Civilização Brasileira, Tomo III: O Brasil

Republicano. Vol. 3. São Paulo: Difel, 1977.

FAUSTO, Ruy. Sentido Da Dialética: (Marx: Lógica E Política): Tomo I. Petrópolis: Vozes, 2015.

FERNANDES, Florestan. Capitalismo dependente e classes sociais na América Latina. $4^{\text {a }}$ ed. São Paulo: Global, 2009. . Mudanças sociais no Brasil. $4^{\mathrm{a}}$ ed. São Paulo: Global, 2008. . A revolução burguesa no Brasil: ensaios de interpretação sociológica. $5^{\text {a }}$ ed. São Paulo: Global, 2005.

FINAZZI-AGRÒ, Ettore. Um lugar do tamanho do mundo: tempos e espaços da fição em João Guimarães Rosa. Belo Horizonte: Ed. UFMG, 2001.

- Aporia e passagem: a sobrevivência do 'trágico' em Guimarães Rosa In SCRIPTA, Belo Horizonte, n.10, v.5, p.122-128, $1^{\circ}$ sem. 2002.

FOUCAULT, Michel. História da sexualidade I: A vontade de saber. $16^{\mathrm{a}}$ ed. Rio de Janeiro: Edições Graal, 1988.

FRANCO, Maria Sylvia de Carvalho. Homens livres na sociedade escravocrata. ${ }^{\mathrm{a}}$ ed. São Paulo: Fundação Editora da UNESP, 1997.

FREUD, Sigmund. "Luto e melancolia" In Introdução ao narcisismo: ensaios de metapsicologia e outros textos (1914-1916). São Paulo: Ed. Companhia das Letras, 2010.

.O mal-estar na cultura. Porto Alegre: L\&PM, 2010. 
. "O inquietante" In História de uma neurose infantil: ("O homem dos lobos"): além do princípio do prazer e outros textos. São Paulo: Ed. Companhia das Letras, 2010.

. "Totem and Taboo - some points of agreement between the mental lives of savages and neurotics" In The Standard Edition of the complete psychological works of Sigmund Freud - Volume XIII (1913-1914) - Totem and Taboo and Other works. London: The Hogarth Press and the Institute of Psychoanalysis, 1953.

FREYRE, Gilberto. Casa-grande \& Senzala: formação da família brasileira sob o regime da economia patriarcal. $51^{\mathrm{a}}$ ed. São Paulo: Global, 2006.

FRIEDRICH, Hugo. Estrutura da lírica moderna: da metade do século XIX a meados do século XX. São Paulo: Ed. Duas Cidades, 1978.

FURTADO, Celso. Brasil: a construção interrompida. Rio de Janeiro: Paz e Terra, 1992.

. Formação econômica do Brasil. $34^{\mathrm{a}}$ ed. São Paulo: Companhia das Letras, 2007. . O mito do desenvolvimento econômico. Rio de Janeiro: Paz e

Terra, 1996.

GALVÃO, Walnice Nogueira. As formas do falso: um estudo sobre a ambigüidade no Grande Sertão: veredas. $2^{\mathrm{a}}$ ed. São Paulo: Ed. Perspectiva, 1986.

GIANNOTTI, José Arthur. Certa herança marxista. São Paulo: Companhia das Letras, 2000. . "Considerações sobre o método" In MARX, Karl. $O$ capital: crítica da economia política: Livro I: o processo de produção do capital. São Paulo: Boitempo, 2013.

GIRARD, René. A violência e o sagrado. $3^{\text {a }}$ ed. São Paulo: Ed. Paz e Terra, 1990.

GRESPAN, Jorge. O negativo do capital: o conceito de crise na crítica de Marx à economia política. $2^{\text {a }}$ ed. São Paulo: Expressão Popular, 2012.

GRESPAN, Jorge. Marx. São Paulo: Publifolha, 2008.

HARVEY, David. Para entender O capital. São Paulo: Boitempo, 2013.

HEGEL, Georg Wilhelm Friedrich. Cursos de estética I. $2^{\mathrm{a}}$ ed. São Paulo: Editora da Universidade de São Paulo, 2001.

HOBBES, Thomas. Leviatã ou Matéria, forma e poder de um estado eclesiástico e civil. $2^{\mathrm{a}}$ ed. São Paulo: Martins Fontes, 2008. 
HOLANDA, Sérgio Buarque de. O espírito e a letra: estudos e crítica literária I, 1920-1947. São Paulo: Ed. Companhia das Letras, 1996. . O espírito e a letra: estudos e crítica literária II, 1948-1959. São Paulo: Ed. Companhia das Letras, 1996. . Raízes do Brasil. 26 a ed. São Paulo: Companhia das Letras, 1995.

JAMESON, Fredric. Late Marxism: Adorno, Or, the Persistence of the Dialectic. London: Verso, 1990. . The Antinomies of Realism. London: Verso, 2013. . Marxismo e forma: teorias dialéticas da Literatura no século XX. São Paulo: Hucitec, 1985. . The political unconscious: narrative as a socially symbolic act. Ithaca: Cornell University Press, 1981.

. Representing Capital: A Commentary of Volume One. London:

Verso, 2011.

KEHL, Maria Rita. A mínima diferença: masculino e feminino na cultura. Rio de Janeiro: Imago Ed, 1996.

LACAN, Jacques. "O estádio do espelho como formador do eu tal como nos é revelada na experiência psicanalítica" In Escritos. Rio de Janeiro: Ed. Jorge Zahar, 1998.

. O seminário, livro 4: a relação de objeto. Rio de Janeiro: Sahar, 1994.

LAFETÁ, João Luiz. 1930, a Crítica e o Modernismo. São Paulo: Livraria Duas Cidades, 1974.

LAGES, Susana Kampff. João Guimarães Rosa e a Saudade. Cotia: Ateliê Editorial, 2002.

LEAL, Victor Nunes. Coronelismo, enxada e voto: o município e o regime representativo no Brasil. $7^{\mathrm{a}}$ ed. São Paulo: Companhia das Letras, 2012.

LUKÁCS, Georg. Marxismo e teoria da literatura. $2^{\mathrm{a}}$ ed. São Paulo: Expressão Popular, 2010. . O romance histórico. São Paulo: Boitempo, 2011. . Soul and form. New York: Columbia University Press, 2010. . A teoria do romance: um ensaio histórico-filosófico sobre as formas da grande épica. São Paulo: Ed. Duas Cidades; Ed. 34, 2000. 
MASCARO, Alysson Leandro. Estado e a forma política. São Paulo: Boitempo, 2013.

MARX, Karl. O 18 de Brumário de Luís Bonaparte. São Paulo: Boitempo, 2011a. - O capital: crítica da economia política: Livro I: o processo de produção do capital. São Paulo: Boitempo, 2013. . Crítica da filosofia do direito de Hegel, 1843. São Paulo: Boitempo, 2010. . A guerra civil na França. São Paulo: Boitempo, 2011 b. . Manuscritos econômico-filosóficos. São Paulo: Boitempo, 2004.

MELLO FILHO, Hélio de. Caso e romance: gêneros e sociedade em Grande sertão: veredas. 2005. 157 f. Dissertação (Mestrado em Literatura Brasileira) - Faculdade de Filosofia Letras e Ciências Humanas, Universidade de São Paulo, São Paulo, 2005.

MORETTI, Franco. O romance, 1: A cultura do romance. São Paulo: Cosac \& Naify, 2009.

NAVES, Márcio Brilharinho. Marxismo e direito: um estudo sobre Pachukanis. São Paulo: Boitempo, 2008.

NAVES, Rodrigo. A forma difícil: ensaios sobre arte brasileira. São Paulo: Companhia das Letras, 2011.

NIETZSCHE, Friedrich. Genealogia da moral: uma polêmica. São Paulo: Companhia das Letras, 1998.

. O nascimento da tragédia ou helenismo e pessimismo. São

Paulo: Companhia das Letras, 2007.

NOBRE, Marcos (org). Curso livre de Teoria Crítica. Campinas: Papirus, 2008.

NOBRE, Marcos. “Depois da 'formação' - cultura e política da nova modernização”. Revista Piauí, nov. 2012. http://revistapiaui.estadao.com.br/edicao-74/tribuna-livreda-luta-de-classes/depois-da-formacao Acesso em: 16/05/2014.

NUNES, Benedito; COUTINHO, Eduardo F (org.). "O amor na obra de Guimarães Rosa” In Guimarães Rosa. Rio de Janeiro: Ed. Civilização Brasileira, 1983.

OEHLER, Dolf. Terrenos vulcânicos. São Paulo: Cosac \& Naify, 2004.

OLIVEIRA, Francisco de. Crítica à razão dualista - $O$ ornitorrinco. São Paulo: Boitempo, 2003.

OLIVEIRA, Francisco De., A Navegação Venturosa: Ensaios Sobre Celso Furtado. São Paulo: Boitempo Editorial, 2003. 
PACHECO, Ana Paula. "Jagunços e homens livres pobres: o lugar do mito no Grande sertão” In Novos Estudos CEBRAP, São Paulo, v.81, p. 179-188, julho de 2008. .O lugar do mito: narrativa e processo social nas Primeiras estórias de Guimarães Rosa. São Paulo: Ed. Nankin, 2006.

O vaqueiro e o procurador dos pobres: Vidas secas. Revista do Instituto de Estudos Brasileiros, Brasil, n.60, p.34-55, abr. 2015.

PASTA JÚNIOR, José Antonio. Formação supressiva: constantes estruturais do romance brasileiro. 2011. 282 f. Tese (Livre docência no departamento de Literatura Brasileira) - Faculdade de Filosofia Letras e Ciências Humanas, Universidade de São Paulo, São Paulo, 2011. . "O romance de Rosa: temas do Grande Sertão e do Brasil” In Novos Estudos CEBRAP, São Paulo, n55, p. 61-70, novembro 1999.

PAULANI, Leda. Modernidade e Discurso Econômico. São Paulo: Boitempo, 2005.

PERICÁS, Luiz Bernardo. Os cangaceiros: ensaio de interpretação histórica. São Paulo: Boitempo, 2010.

POSTONE, Moishe. Tempo, Trabalho e Dominação Social - Uma Reinterpretação Da Teoria Crítica De Marx. São Paulo: Boitempo, 2014.

PRADO JR, Caio. Formação do Brasil contemporâneo: colônia. São Paulo: Companhia das Letras, 2011.

RANCIÈRE, Jacques. The Politics of Literature. Cambridge: Polity, 2011.

RONCARI, Luiz. O Brasil de Rosa: mito e história no universo rosiano: o amor e o poder. São Paulo: Editora UNESP, 2004. - "O lugar da história na obra de Guimarães Rosa" In $O$ cão do sertão: literatura e engajamento: ensaios sobre João Guimarães Rosa, Machado de Assis e Carlos Drummond de Andrade. São Paulo: Editora UNESP, 2007.

SAFATLE, Vladimir. Fetichismo: colonizar o outro. Rio de Janeiro: Civilização Brasileira, 2010. . A paixão do negativo: Lacan e a dialética. São Paulo: Editora UNESP, 2006.

SCHWARZ, Roberto. "Um avanço literário" In Literatura e sociedade, São Paulo, no 13, p. 234-248, 2010.

. Duas meninas. $1^{\text {a }}$ ed. São Paulo: Companhia das Letras, 1997. . Martinha versus Lucrécia: ensaios e entrevistas. São Paulo:

Companhia das Letras, 2012. 
. Um mestre na periferia do capitalismo: Machado de Assis. $4^{\mathrm{a}}$ ed. São Paulo: Duas Cidades; Ed. 34, 2000a.

. Que horas são?: ensaios. São Paulo: Companhia das Letras, 1987.

. Seqüencias brasileiras: ensaios. São Paulo: Companhia das

Letras, 1999.

. A Sereia e o desconfiado - Ensaios críticos. $2^{\mathrm{a}}$ ed. Rio de

Janeiro: Ed. Paz e Terra, 1981.

. Ao vencedor as batatas: forma literária e processo social nos

inícios do romance brasileiro. $5^{\mathrm{a}}$ ed. São Paulo: Duas Cidades; Ed. 34, 2000 b.

SKIDMORE, Thomas E. Brasil: de Getúlio a Castello (1930-64). São Paulo:

Companhia das Letras, 2010.

SONTAG, Susan. Diante da dor dos outros. São Paulo: Ed. Companhia das Letras, 2003.

SOREL, Georges. Reflexões sobre a violência. São Paulo: Martins Fontes, 1992.

SOUZA, Jessé. A Construção Social Da Subcidadania: Para Uma Sociologia

Política Da Modernidade Periférica. Belo Horizonte: Editora UFMG, 2003.

STARLING, Heloisa. Lembranças do Brasil: teoria politica, história e ficção em Grande Sertão: veredas. Rio de Janeiro: Revan, 1999.

WAIZBORT, Leopoldo. A passagem do três ao um: crítica literária, sociologia, filologia. São Paulo: Cosac \& Naify, 2007.

WATT, Ian. A ascensão do romance: estudos sobre Defoe, Richardson e Fielding.

São Paulo: Ed. Companhia das Letras, 2010. 